\title{
DISCLAIMER
}

This report was prepared as an account of work sponsored by an agency of the United States Government. Neither the United States Government nor any agency thereof, nor any of their employees, makes any warranty, express or implied, or assumes any legal liability or responsibility for the accuracy, completeness, or usefulness of any information, apparatus, product, or process disclosed, or represents that its use would not infringe privately owned rights. Reference herein to any specific commercial product, process, or service by trade name, trademark, manufacturer, or otherwise does not necessarily constitute or imply its endorsement, recommendation, or favoring by the United States Government or any agency thereof. The views and opinions of authors expressed herein do not necessarily state or reflect those of the United States Government or any agency thereof.

\section{ASSESSMENT OF THE THEORY}

AND HYPOTHESES OF THE

ACIDIFICATION OF WATERSHEDS

By

Edward C. Krug

Work Performed Under

Contract No. DOE DEFGO2-87ER30

\section{Illinois State Water Survey 2204 Griffith Drive Champaign, Illinois 61820}

This document is

\section{PUBLICL RELEASABLE}

Authorizing Official




\section{DISCLAIMER}

This report was prepared as an account of work sponsored by an agency of the United States Government. Neither the United States Government nor any agency Thereof, nor any of their employees, makes any warranty, express or implied, or assumes any legal liability or responsibility for the accuracy, completeness, or usefulness of any information, apparatus, product, or process disclosed, or represents that its use would not infringe privately owned rights. Reference herein to any specific commercial product, process, or service by trade name, trademark, manufacturer, or otherwise does not necessarily constitute or imply its endorsement, recommendation, or favoring by the United States Government or any agency thereof. The views and opinions of authors expressed herein do not necessarily state or reflect those of the United States Government or any agency thereof. 


\section{DISCLAIMER}

Portions of this document may be illegible in electronic image products. Images are produced from the best available original document. 


\section{ACKNOWLEDGEMENTS}

The author thanks: Derek Winstanley, Allen Lefohn, and Nancy Krug for their extensive critical review and comments; Cliff Thompson and John Adams for information and field guidance in Australia and New Zealand, respectively; Mark Peden for water chemistry data, and Linda Riggin for preparing illustrations and graphics. 


\section{ASSESSMENT OF THE THEORY \\ AND HYPOTHESES OF THE \\ ACIDIFICATION OF WATERSHEDS}

TABLE OF CONTENIS

TITLE PAGE $\ldots \ldots \ldots \ldots \ldots \ldots \ldots \ldots \ldots \ldots \ldots \ldots \ldots \ldots \ldots \ldots \ldots \ldots \ldots \ldots$

ACKNOWLEDGEMENTS $\ldots \ldots \ldots \ldots \ldots \ldots \ldots \ldots \ldots \ldots \ldots \ldots \ldots \ldots \ldots \ldots$

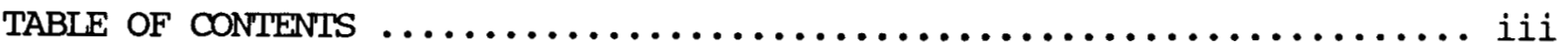

LIST OF TABLES $\ldots \ldots \ldots \ldots \ldots \ldots \ldots \ldots \ldots \ldots \ldots \ldots \ldots \ldots \ldots \ldots \ldots$

IIST OF FIGURES $\ldots \ldots \ldots \ldots \ldots \ldots \ldots \ldots \ldots \ldots \ldots \ldots \ldots \ldots \ldots \ldots \ldots \ldots \ldots \ldots \ldots$

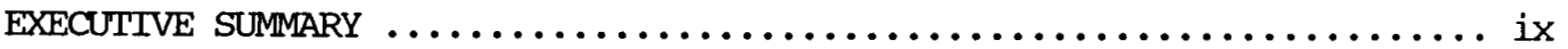

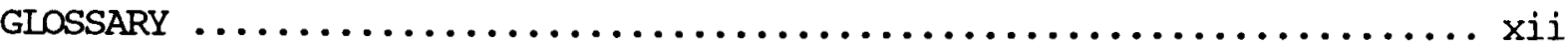

CHAPTER 1. INTRODUCTION $\ldots \ldots \ldots \ldots \ldots \ldots \ldots \ldots \ldots \ldots \ldots \ldots \ldots \ldots \ldots \ldots$

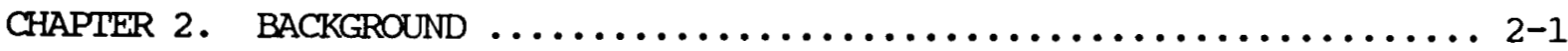

CHAPIER 3. ACIDIFICATION OF SURFACE WATERS: DIRECT OBSERVATIONS,

THEORY, AND HYPOTHESES .......................... 3-1

3.1 Recorded Changes in Surface-Water Chemistry ............... 3-3 3.1.1 Comparison of Historical and Modern water Chemistry

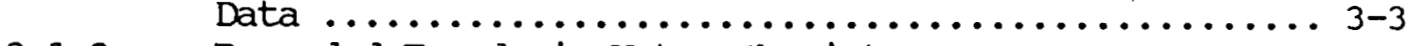

3.1.2 Recorded Trends in Water Chemistry .............. 3-14

3.2 Documented Declines in Fisheries over Time ............... 3-22

3.3 The Distribution of Acid-Stressed and Absent Fish Populations in Relation to the Distribution of Acidic Deposition ........ 3-30

3.4 The Co-occurrence of Natural Soil Acidity with the

Distribution of Acidic Deposition .................... 3-34

3.5 Current surface-Water Chemistry ....................... 3-36

3.6 Non-steady State Watersheds: Iand-Use Changes and Natural

Processes ....................................... 3-57

3.6.1 The Changing Land-Use Hypothesis .............. 3-57

3.6.2 Criticism of the Changing Land-Use Hypothesis ...... 3-70

3.7 Field and Laboratory Experiments ......................... 3-76

3.7.1 Soil and Plant Ion Exchange .................... 3-76

3.7.1.1 SNSF-Project Research and Conclusions ........ 3-76

3.7.1.2 Alternative Hypotheses of Acidification

by Soil and Plant Ion Exchange ............... 3-90

3.7.2 Some Acidification and Buffering Mechanisms of Highly Acidic, Organic Rich Landscape Elements ... 3-114 


\subsubsection{Weak Acid Acidification/Buffering by}

Humic Substances ..................... 3-124

3.7.2.2 pH-Dependent Solubility of Terrestrial

Humic Substances ..................... 3-132

3.7.2.3 Flocculation of Humic substances from Solution . 3-147

3.7.2.4 Strong Acid Production by Weak Acids in Soils .. 3-154

3.8 Paleolimnological Investigations ..................... 3-163

3.9 Observations of Naturally-Acidic Waters Associated with

Acidic Soils not Exposed to Man-Made Acidic Deposition ...... . 3-172

3.9.1 Recently-Glaciated "Sensitive" Watersheds ......... 3-175

3.9.2 Non-Glaciated "Sensitive" Watersheds ............. 3-186

CHAPTER 4. CONCLUSIONS $\ldots \ldots \ldots \ldots \ldots \ldots \ldots \ldots \ldots \ldots \ldots \ldots \ldots \ldots \ldots \ldots \ldots$

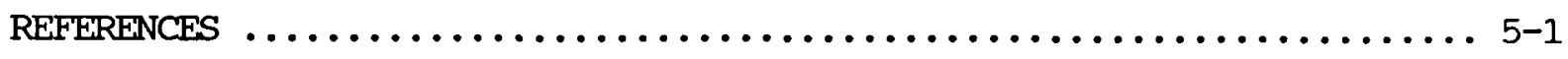


Table 1. Some Water Chemistry Data for Nova Scotian Rivers ....... 3-11

Table 2. Wet Deposition of $\mathrm{SO}_{4}{ }^{2-}$ and Discharge of $\mathrm{SO}_{4}{ }^{2-}$ for

Swedish Rivers by Region ...................... 3-16

Table 3. Mean Chemical Values of Geographic/Chemical Lake Groups Obtained by a Cluster Analysis of the 1974 Survey of Small Headwater Lakes in Southern Norway

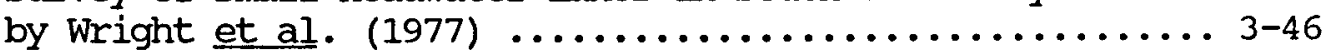

Table 4. Some Mean Chemical Parameters of $\mathrm{pH}<5.0$ Southern Norwegian and Eastern United States Lakes of the National Surface Water survey (NSWS) .............. 3-50

Table 5. Numbers of Small, Headwater, Southern Norwegian Lakes Surveyed in 1974 by Visual Color and pH ......... 3-53

Table 6. Effect of Humus Developed on Abandoned Farmland on $\mathrm{pH}$ of leachate from Simulated Rain ................. 3-60

Table 7. Land Classification (1909-1910) Survey of the Mainland of Nova Scotia ...................... 3-73

Table 8. Mean Water Chemistry Data for Snowmelt from $\mathrm{pH} 7.0$ Snowpack in a Norwegian Mini-Catchment ............. 3-83

Table 9. Mean Rain and Runoff Chemistry Reported for Norwegian Mini-Catchments ............................. 3-84

Table 10. Some Characteristics of Norwegian Mini-Catchments 1 and 2 whose Runoff Chemistry was Described in Table 9 ................................. 3-85

Table 11. Water Chemistry Data $(1955,1977)$ for Nova Scotian Lakes on Granite Bedrock Watersheds ................ . 3-100

Table 12. The Influence of Proximity to the Ocean on Exchangeable Bases in Humus of Southern Norway ......... 3-103

Table 13. Some Measured and Predicted Chemical Values for Cahoon Pond (1D2-078) -- A NSWS pH<5.0 Clearwater Seepage Pond on Cape Cod .......................... 3-105

Table 14. Select Mean Water Chemistry Data for the Enmons Watershed, $1983-84$............................ 3-110 
Table 15. The pH of Leachate Generated by Passing Simulated Precipitation Through Soil Horizons From Three Forest Cover Types on the Raven Fork Watershed

Table 16. Comparison of Some Highly Acidic Adirondack and Australian Waters

Table 17. Some Mean Chemical Data for Runoff from the Risdalsheia Mini-Catchments in Southermmost Norway Receiving Ambient Acidic Deposition and Simulated "Clean Atmospheric Deposition" ................... 3-140

Table 18. Composition of Australian Humic Water Before and After Leaching Through Two Podzol A and Two Podzol C Horizons ............................ 3-159

Table 19. Some Chemical Parameters of the $17 \mathrm{pH}<5.0$ Surface Waters Found of 75 Surveyed in Western Tasmania by Buckney and Tyler (1973)

Table 20. Water Chemistry Data for Some $\mathrm{pH}<5.0$ Surface Waters of the West coast of the South Island of New Zealand.

Table 21. Some Chemical Parameters of the $25 \mathrm{pH}<5.0$, found in the 150 Lakes of the "Florida" Sampling Region of the NSWS

Table 22. Some Physical and Chemical Data for Lakes in Frazier Island, Australia....................... 3-193

Table 23. Water Chemistry Data For Cooloola-Noosa

Surface waters.............................. 3-195 
IIST OF FIGURES

Figure 1. Annual mean $\mathrm{pH}$ of precipitation at three Norwegian

stations over time $\ldots \ldots \ldots \ldots \ldots \ldots \ldots \ldots \ldots \ldots \ldots \ldots . . \ldots 2-4$

Figure 2. The pH of precipitation over time in Scandinavia according to the U.S. National Research Council

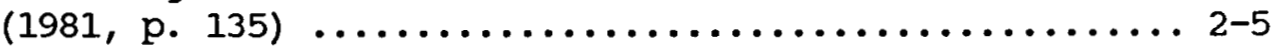

Figure 3. Distribution of mean annual precipitation $\mathrm{pH}$ for southern Norway (1972-1975) in relation to the locations of some lakes recorded to have been acidified over a forty year period ................ 3-4

Figure 4. Mean annual concentrations of $\mathrm{SO}_{4}{ }^{2-}$ in Norwegian precipitation and river water .................. 3-18

Figure 5. Comparison of historical salmon catch data for 7 Norwegian rivers that have lost salmon compared with 68 other Norwegian salmon rivers $\ldots \ldots \ldots \ldots \ldots \ldots . . . . .23$

Figure 6. Status of fish populations in lakes of southern Norway in relationship to the distribution of mean annual precipitation $\mathrm{pH}$ and locations of some reportedly acidified lakes .................... 3-31

Figure 7. An example of estimation of surface-water acidification by $\mathrm{H}_{2} \mathrm{SO}_{4}$ deposition using typical contemporary water-chemistry data for "sensitive" coastal freshwaters of Scandinavia and eastern North America ............................... 3-37

Figure 8. Henriksen predictive nomograph showing $\mathrm{pH}$ 5.3-4.7 chemical domains for Norwegian lakes ............. 3-40

Figure 9. Idealized hydrologic, soil, and vegetation altitudinal gradients of the Adirondack Mountains of New York ................................ 3-67

Figure 10. The influence of $10^{-5}, 10^{-4}, 10^{-3} \mathrm{~N} \mathrm{NaCl}(----)$, $10^{-5}(\mathrm{pH}=5), 10^{-4}(\mathrm{pH}=4), 10^{-3} \mathrm{~N}(\mathrm{pH}=3) \mathrm{H}_{2} \mathrm{SO}_{4}$, (- - ), and rest periods on the $\mathrm{pH}$ of leachate from humus ............................. 3-77

Figure 11. The effect of simulated pH 5 with normal background level of salt (----) and, partly through the experiment, without salt (-) on runoff $\mathrm{pH}$ from "barren" bedrock with $20 \%$ lichen cover in southern

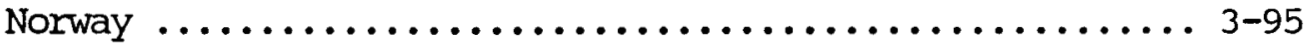


Figure 12. Titration of a bicarbonate solution of mineral bases by sulfuric acid

Figure 13. Titration of a humic acid solution by sulfuric acid .... 3-126

Figure 14. Potentiometric titration curves for acidsaturated peat in the presence of $0,0.004$, $0.01 \mathrm{M} \mathrm{AlCl}_{3}$, and $0.01 \mathrm{M} \mathrm{AlCl}_{3}$ alone $\ldots \ldots \ldots \ldots \ldots . . . . .151$ 
This report documents and critically assesses the evolution and status of the scientific understanding of the effects of acidic deposition on surface waters. The main conclusion is that the dominant theory of surface-water acidification fails to adequately incorporate many important factors and processes that influence surface water acidity. Some of these factors and processes are not well researched or recognized as being important by most scientists in the aquatic effects research area.

An assessment of the effects of acidic deposition on surface waters based on the dominant theory of surface-water acidification will overestimate significantly the effects of acidic deposition. This theory states that, in the absence of acidic deposition, water chemistry of sensitive watersheds is essentially geologically controlled and is the product of carbonic acid weathering of mineral bases which produces alkalinity. By theory, acidic deposition consumes this watershed-produced alkalinity thereby increasing water acidity and releasing toxic aluminum from watersheds into water.

However, the principal influence of acidic deposition on currently acidic $(\mathrm{pH}<5.5)$ Norwegian and northeastern U.S.A. lakes appears not to be a marked acidification, but a qualitative shift in the nature of acidity from organic acid water to sulfuric acid water and a concomitant increase in the proportion of ionic aluminum. Acidification of surface waters by acidic deposition is superimposed on natural processes of acidification.

Acidic surface waters respond as predicted by the alternative hypothesis of surface-water acidification. It states that the water chemistry of most currently acidic lakes and streams is not geologically controlled, nor was it geologically controlled by weathering of mineral bases prior to acidic deposition. currently acidic surface waters receive lange amounts of nearsurface runoff from highly acidic, organic-rich soils and peats and/or acidophilic ecosystems.

It is recommended that the identified factors and processes be incorporated into a revised, more comprehensive theory of surface-water acidification and into mathematical models used to predict changes in surface water chemistry.

Full and careful consideration of these additional factors and processes, and more comprehensive and critical evaluation of scientific information will lead to a more credible assessment of the role of acidic deposition in surface-water acidification.

Some important facts that are widely or prominently reported include the following:

- Paleolimnological studies indicate that approximately 90 percent of currently acidic $(\mathrm{pH}<5.5)$ surface waters examined in the northeastern U.S.A. and southern Norway were naturally acidic $(\mathrm{pH}<5.5)$ in pre-industrial times.

- Many surface waters of "sensitive" watersheds in areas of the world not receiving acidic deposition are naturally acidic: for example, 37 percent of sampled surface waters in recently glaciated southwestern Tasmania have 
$\mathrm{pH}<5.5(28 \% \mathrm{pH} \leq 5.0) ; 84$ percent of the main lakes on non-glaciated Frazier Island, queensland are $\mathrm{pH}<5.5(79 \% \mathrm{pH} \leq 5.0)$, and; numerous highly acidic waters with $\mathrm{pH}$ as low as 3.3 occur in recently glaciated Westland, New Zealand, where precipitation $\mathrm{pH}$ is $5.6-5.7$.

- Naturally acidic surface waters have acid-stressed aquatic ecosystems and chemical analysis has shown that they can have natural forms of toxic aluminum.

- In "sensitive" watersheds, natural soil formation that occurs after landuse changes has enormous acidification potential. For example, in just 90 years, reforestation of an abandoned farm field resulted in highly acidic surface soil horizons whose acid content is equivalent to about 1,000 years of pH 4.3 acid rain. Such land-use changes have cocurred over nearly all of the eastern U.S.A.; for example, 99.5 percent of New York's forests were cut and/or burned by the 1920's.

- Laboratory and field experiments show that snowmelt pH consistently resembles soil $\mathrm{pH}$ and is but little influenced by snowpack acidity.

- It is possible that current concentrations of dissolved humic acids alone could result in $\mathrm{pH}$ values less than 5.0 for over 50 percent of the highly acidic $(\mathrm{pH}<5.0)$ lakes found in the eastern U.S.A. by the National Surface Water survey.

These facts contract the dominant theory of surface-water acidification which states that most currently acidic surface waters are acidic because of acidic deposition.

Some of the factors and processes that need to be considered more comprehensively and critically in order to establish a sound scientific basis for conducting an assessment include the following:

- The $\mathrm{H}^{+}$content of the watersheds themselves, as well as $\mathrm{H}^{+}$from acidic deposition;

- The importance of abundant elements, such as hydrogen, in naturallyoccurring, non-ionic compounds that can be converted to acids;

- The acidification of surface waters by strong mineral acids produced by soil and plant ion exchange;

- The inclusion of erosional and depositional watershed processes in watershed input/output budgets;

- The climatically-driven gradients in natural soil acidity;

- The comprehensive consideration of the acidification/buffering nature of organic acids;

o The production of strong mineral acids from flocculated weak organic acids in soils and surface waters;

- The interactions of acid-with-acid, as well as acid-with-base; 
- The production of strong acids from neutral salts;

- The enormous acid neutralizing capacity of even granitic watersheds, and;

- The creation of regional acidic deposition and regional changes in land use are fundamentally linked by a common causal agency - technological and societal change.

The alternative hypothesis of surface-water acidification has been developed from the following nine categories of observations:

1. Recorded changes in surface-water chemistry over time;

2. Documented declines in fisheries over time;

3. The distribution of acid-stressed and absent fish populations;

4. The correlation of soil acidity with climate and acidic deposition;

5. Current surface-water chemistry;

6. Non-steady state watersheds - land-use changes and natural processes;

7. Field and laboratory experiments;

8. Paleolimnological investigations, and;

9. Observations of naturally acidic surface waters associated with acidic soils of "sensitive" watersheds not exposed to man-made acidic deposition.

More research is needed to quantify the role of these additional factors and processes versus the role of acidic deposition in surface-water acidification in eastern North America.

Chapter 1 introduces the report by describing the assessment in the context of the National Acid Precipitation Assessment Program (NAPAP). Chapter 2 provides background on the evolution of scientific thought that led to the establishment and much of the character of NAPAP, especially its program on aquatic effects. Chapter 3 examines critically the supporting evidence for accepted theory and alternative hypotheses of surface-water acidification. conclusions are presented in chapter 4. 


\section{GLOSSARY}

Acid - a substance that can contribute Hydrogen ion $\left(\mathrm{H}^{+}\right)$to water or is capable of donating $\mathrm{H}+$ to react with a base.

Acid Lake - a lake more acidic than predicted on the basis of carbonate chemistry alone.

Acid Neutralizing Capacity (ANC) - The measure of the quantity of all base substances, including humate $\left(\mathrm{RCOO}^{-}\right)$and carbonate species, that participate in titration by acid. ANC is an operational definition for the total base content of water and soil.

Acidity - the measure of the quantity of acid in solution or soil.

Acidification - the process by which soil or water becomes more acidic.

Acidophilic - acid-loving organisms or ecosystems. Acidophilic ecosystems helped to create their acidic environment. They work to maintain the acidic enviromment that they prefer or require to exist in.

Alkalinity - the quantity of $\mathrm{HCO}_{3}^{-}, \mathrm{CO}_{3}^{2-}$, and $\mathrm{OH}^{-}$in water. Alkalinity, while rigorously defined as being the measure of all base substances in solution that participate in titration by acid, is commonly considered to be the measure of a water's ability to neutralize inputs of acid (titration either in the laboratory or in surface water) based on $\mathrm{H}_{2} \mathrm{CO}_{3}$ weathering of mineral bases.

Base Neutralizing Capacity (BNC) - the measure of the quantity of all acidic substances that participate in titration by base. BNC is an operational definition of the total acid content of water and soil.

Conjugate Base - The anion of an acid is the conjugate base of that acid. For example, $\mathrm{HCO}_{3}^{-}$(bicarbonate) is the conjugate base of $\mathrm{H}_{2} \mathrm{CO}_{3}$ (carbonic acid): $\mathrm{H}_{2} \mathrm{OO}_{3}=\mathrm{H}^{+}+\mathrm{HCO}_{3}{ }^{-}$. In the aquatic effects literature, the term, "strong acid anion" is often used in place of conjugate base. For example, $\mathrm{SO}_{4}{ }^{2-}$ is said to be the "strong acid anion" of $\mathrm{H}_{2} \mathrm{SO}_{4}$ (sulfuric acid).

Dissolved Organic Carbon (DOC) - organic carbon that is in solution. DOC is commonly used as a surrogate measure of humic acid.

Electrolyte - an ionic substance. Ionic substances can be neutral salts such as common table salt $\mathrm{NaCl}$, acid such as sulfuric acid $\left(\mathrm{H}_{2} \mathrm{SO}_{4}\right)$, or base such as lye $(\mathrm{NaOH})$.

Electroneutrality - the condition where the concentration of negativelycharged ions (anions) equal the concentration of positively-charged ions (cations).

Flocculation - the process by which substances aggregate into particles large enough to settle out of solution.

Organic Acid - an acid that is organic. Organic acids in surface waters are 
commonly believed to be humic acids.

$\mathrm{pH}$ - the negative logarithm of the charge equivalent concentration of $\mathrm{H}^{+}$. For example $10^{-7}$ equivalents of $\mathrm{H}^{+}$per liter is $\mathrm{pH}=7.0$.

Quartzose - mineral soils or rocks that are made up of mostly quartz $\left(\mathrm{SiO}_{2}\right)$. An example of quartzose material is common, non-carbonate beach sand.

Siliceous - silica-bearing mineral material. Siliceous includes all minerals that contain silicon ( $\mathrm{Si}$. Most siliceous minerals contain $\mathrm{Al}$, and some base cations such as $\mathrm{Ca}^{2+}, \mathrm{Mg}^{2+}, \mathrm{Na}^{+}, \mathrm{K}^{+}$as well as $\mathrm{Si}$.

Strong Acid - used here to mean an acid that is completely dissociated at the range of $\mathrm{pH}$ values observed for surface waters.

Strong Acid Anion - ia a term often used in the aquatic effects literature in place of conjugate base. For example, $\mathrm{SO}_{4}{ }^{2-}$ is said to be the "strong acid anion" of $\mathrm{H}_{2} \mathrm{SO}_{4}$ (sulfuric acid): $\mathrm{H}_{2} \mathrm{SO}_{4}=2 \mathrm{H}^{+}+\mathrm{SO}_{4}{ }^{2-}$.

Titration - The process by which one chemical component is consumed by the addition of another chemical component. Acid/base titration is the key concept used by aquatic scientists to model acidification of surface waters.

Weak Acid - an acid that is not necessarily completely dissociated at the range of $\mathrm{pH}$ values observed for surface waters. A common example of a weak acid is humic acid. 
CHAPTER 1

\section{INTRODUCTION}

There is widespread belief that acidic deposition has caused lakes and streams in eastern North America to become acidic and lose their fish populations (Galloway et al., 1978). The perceived aquatic effects of "acid rain" have been the prime motivation for public and political calls to further reduce the emissions of the pollutants, especially sulfur dioxide $\left(\mathrm{SO}_{2}\right)$ from utilities and other heavy industrial sources.

In response to public and political concern, research on aquatic effects is currently supported by a number of public and private sponsors in the United States and abroad. In the United States, the National Acid Precipitation Assessment Program (NAPAP) coordinates the Federal Government's efforts to improve the understanding of the causes and effects of acidic deposition, including an assessment of the role of acidic deposition in surface-water acidification.

NAPAP is a 10-year program organized along the lines originally recommended by Galloway et al. (1978). NAPAP's funding level may reflect the intense public and political interest in "acid rain". Funding for NAPAP has been much greater than the average of $\$ 10$ million per year $(\$ 100$ million for the entire 10 years) originally recommended (Galloway et al., 1978). For example, NAPAP's annual budget in 1988 alone is about \$85 million, of which around $\$ 25$ million, or 30 percent, is allocated for research on aquatic effects.

To fulfill its mandate of providing scientifically-sound information 
needed by congress and others, NAPAP produces reports documenting research progress and scientific assessments of acidic deposition issues. In September 1987, NAPAP released its Interim Assessment of the causes and consequences of acidic deposition (NAPAP, 1987a). NAPAP's accompanying press release (NAPAP, 1987b) focused on aquatic effects. It was reported in the press release that there is no significant direct effect of acidic deposition on trees or crops, but that acidic deposition does contribute significantly to the acidification of some lakes in the upper Midwest and the northeastern United States. In Canada and Scandinavia, it is also widely believed that acidic deposition is the main cause of acidic surface waters, and that further reductions in emissions of sulfur will reduce the acidity of surface waters (NAPAP, 1987b).

NAPAP's Interim Assessment (NAPAP, 1987a) was highly criticized by some scientists. SCIENCE magazine reported that:

"Most of the criticisms center on the report's depiction of aquatic effects to date, the best understood effect, and the one that galvanized the scientific community and captured public attention in the 1970's" (Roberts, 1987).

Thus, despite the belief that the aquatic effects of acidic deposition is the best understood effects area, this area remains very controversial. Questions arise about the belief that we are dealing with a well-known effect and about the reported scientific consensus that the processes of surfacewater acidification are well understood and well reported.

As congress continues to deliberate on the issues of acidic deposition, and as NAPAP moves towards the delivery of its Final Assessment in 1990, it is critical to insure that scientists and decision makers do not overlook important views. All major effects and processes of surface-water acidification must be adequately considered in order to accurately assess any 
damage and the benefits of further emissions controls and mitigation efforts.

To fulfill its mandate of providing scientifically-sound information needed by Congress and others, NAPAP's assessment of aquatic effects of acidic deposition has established the following guidelines:

"o To provide useful information for policy development ...:"

"o It must be credible, both to scientific reviewers and the users of the assessment information."

"O The assessment must be comprehensive, by examining the entire range of plausible causes, effects and control approaches."

"O It must be critical, endorsing hypotheses that are supported by scientific research and rejecting unsubstantiated hypotheses." (NAPAP, 1988, p.vii).

In order to factually assess the role of acidic deposition in surfacewater acidification many factors must be considered. These factors include many complex processes by which deposited acids interact with soils, vegetation, geology, surface waters and their sediments in the context of spatial and temporal variation of hydrologic flowpaths. Due consideration must also be given to the many complex processes that cause soils and surface waters to be naturally acidic, to other causes of acidification (such as acid-mine drainage), and to non-steady-state processes that may result in reacidification of watersheds (e.g., recovery from land-use change and natural disturbances).

This report will critically examine data and theories said to prove widespread and profound chronic degradation of aquatic resources by acidic deposition. It will examine the reported scientific consensus that the processes governing surface-water acidification are reasonably well understood and well reported. The report will also examine some alternative hypotheses of surface-water acidification. 
Such critical examination, by definition, is not a synopsis or systematic review of the past and current generally-accepted themes found in the acid rain literature. The method of critical examination is one by which consistency, both internal consistency and consistency with the external biological, chemical, and geological literatures, are examined. Such an examination of consistency, as performed in this report, necessarily determines if the reported understanding is comprehensive (i.e., if all important views, effects and processes of aquatic acidification are objectively and seriously considered in the reported consensus) and is, therefore, credible.

Critical examination is the strength of the modern scientific method.

The extent to which data and theory withstand critical examination is an indication of their scientific credibility and acceptability. 
CHAPTER 2

BACKGROUND

This chapter presents the evolution of scientific thought as a foundation for understanding today's scientific theory and current understanding of surface-water acidification.

The monitoring and research results from Scandinavia in the 1940's through the 1970's have had a major influence on current understanding of the aquatic effects of acidic deposition. These results are important because they have been seminal in the development of surface-water acidification theory. Furthermore, the watersheds of highly acidic surface waters in Scandinavia and recently-glaciated regions of eastern North America are similar and, therefore, are expected to react similarly to acidic deposition. Thus, the reported findings of these Scandanavia studies are perceived as being highly relevant to understanding aquatic effects in much of eastern North America.

Acidification of surface waters was believed to be in response to the expansion of acidic deposition out of industrial and urban centers since the mid-1950's to cover a large areas of eastern North America and northern Europe.

Significant study of acidic deposition in Scandanavia began shortly after the Second World War. Due to oil shortages during the War, there was intense operation of an oil shale extraction plant in southermmost Sweden. Apparently, high levels of emissions from this plant resulted in serious folliar damage around the facility. After the War, Swedish scientists set up a major experiment to study the effects of these emissions on forests and 
crops. As part of this study, an atmospheric-monitoring network was established (Johansson, 1959).

As the study progressed, scientists observed that precipitation at the upwind (southern) sampling sites was progressively becoming more acidic and that sulfuric acid $\left(\mathrm{H}_{2} \mathrm{SO}_{4}\right)$ in precipitation was expanding northward across their monitoring network in southern sweden. This expansion of $\mathrm{H}_{2} \mathrm{SO}_{4}$ deposition was apparently the result of increasing industrial activity in mainland Europe. Having become aware of the potential effects of acidic deposition, Sweden established in the late 1940's the first national acidic deposition effects project and the first large-scale precipitation chemistry network in Europe. Agricultural colleges, experiment stations, and agricultural high schools were employed to study this potentially serious environmental problem (Johansson, 1959). Later, one of the program's scientists (Eriksson) would become the "father" of the European Air Chemistry Network which predate the National Atmospheric Deposition Program (NADP) of the United States by about 25 years (Cowling, 1980; 1982).

This swedish project is acknowledged as being historically important because it was the first national acidic deposition effort as well as the prototype national acidic deposition monitoring network (Cowling, 1980; 1982). This Swedish program was unable to identify any effects of either ambient or simulated environmental levels of wet deposition and $\mathrm{SO}_{2}$ on $\mathrm{crops}$ or forests, which is not well reported in the effects literature. Furthermore, the results of the program indicated that swedish agriculture suffered almost universally from sulfur deficiency. Acidic deposition was credited with improving both crop yield and its protein content in southern Sweden. The final report of the project was appropriately titled, "On Sulfur 
Problems in Swedish Agriculture" (Johansson, 1959). Correspondingly, agricultural application of sulfur in fertilizer increased from about $7 \mathrm{~kg}$ $\mathrm{S} / \mathrm{ha}-\mathrm{yr}(21 \mathrm{~kg} \mathrm{so} / \mathrm{ha}-\mathrm{yr})$ to greater than $20 \mathrm{~kg} \mathrm{~s} / \mathrm{ha}-\mathrm{yr}(60 \mathrm{~kg} \mathrm{sO} / \mathrm{ha}-\mathrm{yr})$ (Oden, 1979) as a result of the project (Johansson, 1959).

Norway closely followed sweden in establishing a precipitation-chemistry network. Paralleling the Swedish observation, acidic deposition was seen by the Norwegians to be expanding northward out from the heart of industrial Europe. The time trends for annual mean $\mathrm{pH}$ of precipitation at three locations in southermmost Norway show a marked increase in acidity of precipitation in the 1960's (Figure 1), as did similar data for Scandinavia reported by the U.S. National Research Council (1981; Figure 2). Lista, a sampling location on the coast at the southermmost tip of Norway (location shown in Figure 3), recorded in 1955-1962 a mean precipitation pH of 4.9 (Lag, 1968) and a mean $\mathrm{pH}$ of 4.3 in 1974-1975, a four-fold increase in the $\mathrm{pH}$ measure of acidity (Wright and Henriksen, 1978). Mean regional concentration of non-marine $\mathrm{SO}_{4}{ }^{2-}$ in precipitation of southern Norway doubled in the 1960's accompanied by a marked increase in acidity of precipitation (Braekke, 1976).

The increase in acidity and the increase in areal extent of acidic deposition in Europe was thought to be correlated with: (i) a doubling of European $\mathrm{SO}_{2}$ emissions between 1950 and 1970; (ii) the use of tall smokestacks to disperse emissions over a wider area, and; (iii) the use of scrubbers and cleaner-burning fuels to reduce emissions of particulates (which contained bases that act to neutralize emitted acid-forming substances) to alleviate local air pollution problems. These factors are believed to have transformed local air pollution and soot problems into regional acidic deposition (Likens and Bormann, 1974; Braekke, 1976; 


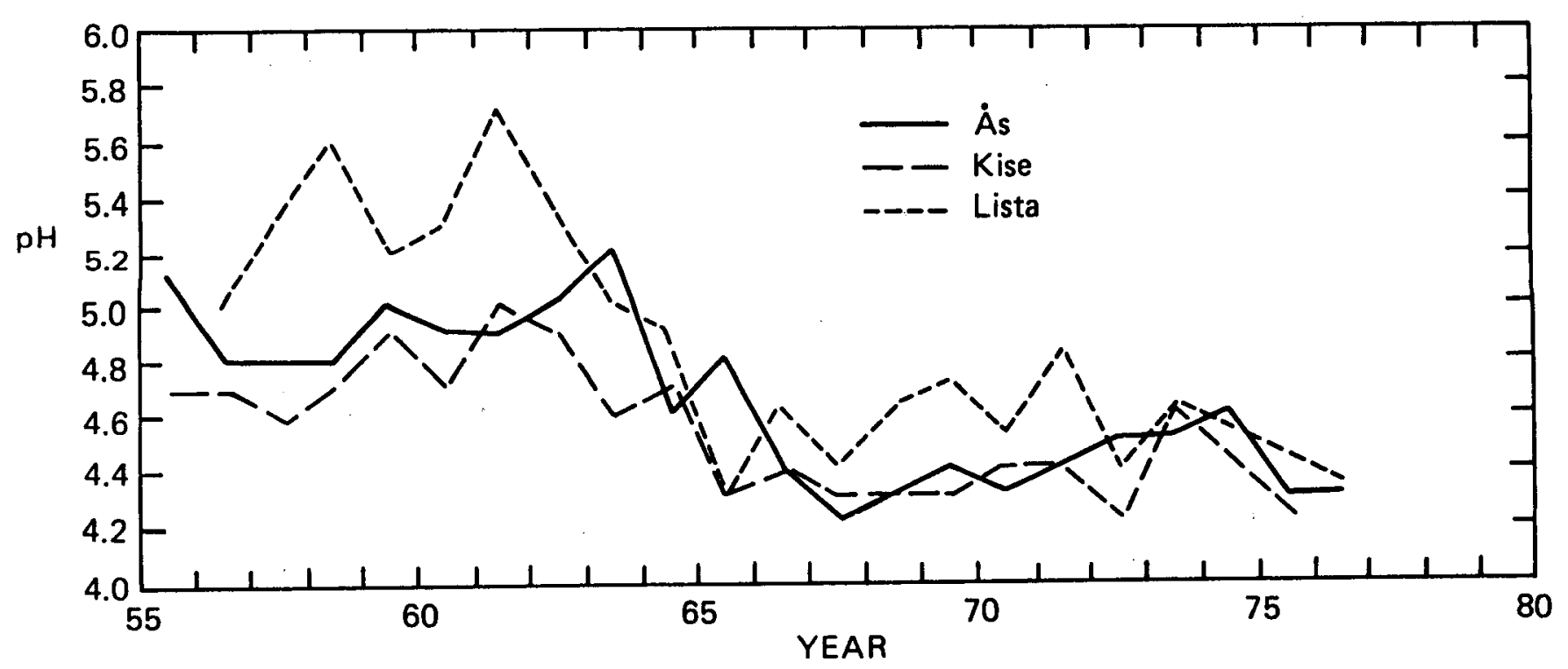

Figure 1. Annual mean $\mathrm{pH}$ of precipitation at three Norwegian stations over time. Modified from Seip and Tollan (1978). 


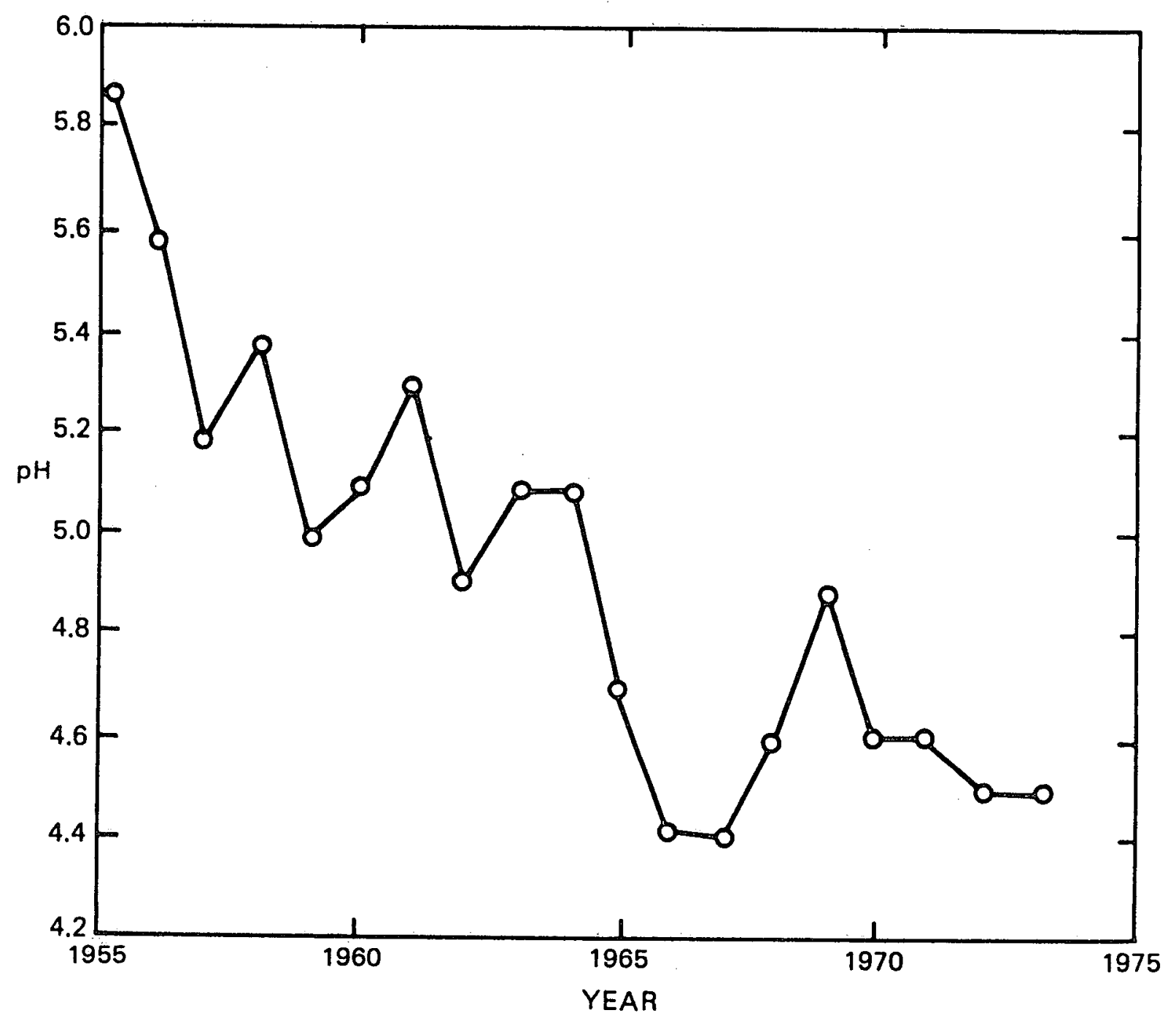

Figure 2. The $\mathrm{pH}$ of precipitation over time in Scandinavia according to the U.S. National Research Council (1981, p. 135).

$$
2-5
$$


Overrein et al., 1980).

Through the 1970's, there was no significant trend reported for concentration of $\mathrm{SO}_{4}{ }^{2-}$ or emission of $\mathrm{SO}_{2}$ (overrein et al., 1980). The spatial distribution of acid precipitation over southern and central

Norway in 1972-1975 (Braekke, 1976; Wright, 1977) apparently closely resembles that of today (Reuss et al.,1987).

In 1972, Norway established an 8-year national research project named, "Acid Precipitation-Effects on Forests and Fish Project" (SNSF-Project). The SNSF-Project published an "interim assessment" (Braekke, 1976) and a Final Report (Overrein et al., 1980). No direct measurable significant effect of acidic deposition on forests was reported (Braekke, 1976; Overrein et al., 1980).

The SNSF-Project conducted the most intensive and extensive study of its time on the aquatic effects of acid rain and was to have a profound influence on NAPAP's assessment of the aquatic effects of acid rain. The SNSF-Project concluded that there had been widespread and profound chronic degradation of aquatic resources by acidic deposition in southern Norway (Braekke, 1976; Overrein et al., 1980).

In Sweden, data from a national hydrological monitoring program established in 1965 was reported as showing a marked trend of decreasing pH and alkalinity $\left(\mathrm{HCO}_{3}{ }^{-}\right)$accompanied by increasing $\mathrm{SO}_{4}{ }^{2-}$ in rivers. Water chemistry was also reported as corresponding to a north-south $\mathrm{H}_{2} \mathrm{SO}_{4}$ deposition gradient across Sweden (Oden, 1976; 1979). The reported spatial and temporal coincidence of acidification of surface water and precipitation chemistry by ongoing national deposition monitoring and surface water monitoring networks (Oden, 1976; 1979) presented a very powerful argument 
for acidification of water by acidic deposition (i.e., titration and loss of alkalinity by sulfuric acid). These Swedish results were reported as having significantly influenced scientific thought concerning the aquatic effects of acidic deposition (Cowling, 1980; 1982).

Canadian studies on the aquatic effects of regional acidic deposition started somewhat later than those of Norway and Sweden. As late as 1976 it was reported that: .

"There is no published study at present that identifies long-range transport of acid (from many point sources) as affecting canadian lakes" (Beamish, 1976).

However, studies were underway. Like Sweden, the damage created at a "hot spot" stimulated Canadian interest in acid rain. The canadian hot spot was the world's largest $\mathrm{SO}_{2}$ emitter - the Sudbury nickel and copper smelter complex in ontario. And less than 100 miles to the north of Sudbury was yet another smelter complex that was the world's second largest point source of $\mathrm{SO}_{2}$ (Beamish, 1976).

As of 1976 information existed reporting Canadian lakes as having been acidified by the massive point source emissions from sudbury smelter complex (Beamish, 1976). Reports of aquatic acidification by regional acidic deposition scon followed, however, particularly for Nova Scotia.

Like Scandanavia, Nova Scotia was reported to be an area whose precipitation became unnaturally acidified after the mid-1950's (Likens et al., 1979; Watt et al., 1979; Thompson et al., 1980; National Research Council; 1981). However, unlike Scandinavian data, prior to the 1970's, precipitation chemistry data exists for only one location and only for the mid-1950's. There is question as to whether the earlier 1950's precipitation chemistry data for Nova Scotia is accurate or not (Kramer and Tessier, 
1982) .

Returning to acidification of surface waters, increased deposition of $\mathrm{H}_{2} \mathrm{SO}_{4}$ was reported to be reflected in increased acidity and concentration of $\mathrm{SO}_{4}{ }^{2-}$ in both Nova Scotian lakes (Watt et al., 1979) and rivers (Thompson et al., 1980). Unlike other historical surface water chemistry data, the historical Nova Scotian lake data were considered to be of high quality and directly comparable to modern water chemistry data for most chemical parameters (Watt et al., 1979).

A recorded decline in alkalinity of Clear Lake in Ontario between 1967 and 1977 was reported to be, presumably, the result of regional acidic deposition (Dillon et al., 1978; National Research Council, 1981).

In conclusion, the accumulation of studies reporting detrimental effects of acidic deposition resulted in increasing concern for protection of the environment, particularly the aquatic environment. A mood was established that resulted in pressure for the United States to initiate a national acidic deposition research program. In Congressional testimony, Dr. Ellis Cowling discussed the creation of the National Acid Precipitation Assessment Program (NAPAP) .

"In the fall of 1977, I joined with three other scientists from the NADP, in drafting a report to the President's Council on Environmental Quality entitled A National Program for Assessing the Problem of Atmospheric Deposition (Acid Rain). This publication (Galloway et al., 1978) provided the basis for the Presidential initiative on Acid Rain which was announced in August 1979, (Carter, 1979). During the summer of 1980, I also worked together with scientists in various federal agencies in developing the 'National Acid Precipitation Assessment Plan'..." (Congressional Committee on Energy and Commerce, 1982, p. 330).

In their executive summary, Galloway et al. (1978) state:

"Acid precipitation is a major envirommental problem on both sides of 
the Atlantic Ocean."

"In the United States, acid precipitation is one of the two major environmental problems recognized by the president's council on Enviromental Quality."

"The continuing, unchecked environmental degradation caused by acid precipitation could reach a stage where the damage to natural ecosystems would be irreversible."

"The time has come to stop talking and to implement a comprehensive and well-coordinated program of research and monitoring. The United States already lags well behind other nations (including Canada, Norway, and Sweden) despite the severe threat posed by acid precipitation to large areas of this country."

"Thanks largely to research efforts in northern Europe and Canada, the effects of strong acids and many other substances on fish and other aquatic organisms are becoming much better understood. The effects are generally catastrophic for fish--particularly in southern Sweden and Norway, eastern Canada, and in the northeastern United States. By contrast, effects on commercial and urban forests, agricultural crops, wetlands, and our system of National Parks are largely unknown."

Reports of pervasive and severe acidification of surface waters in the Northeast and Appalachians were numerous just prior to and during the early years of NAPAP. Acidification of surface waters was believed to be in response to the expansion of acidic deposition out of industrial and urban centers since the mid-1950's to cover a large area of eastern North America (Likens et al., 1979; National Research Council, 1981).

Schofield (1976) reported that surveys of high altitude lakes and ponds in the Adirondacks showed that the percentage of $\mathrm{pH}$ less than 5.0 waters increased from $4 \%$ in the 1930's to over 50\% in the mid-1970's. About $90 \%$ of these $\mathrm{pH}$ less than 5.0 waters in the mid-1970's were said to be fishless (Schofield, 1976).

Hendrey et al. (1980) and Burns et al. (1981) claimed that the pH of 79\% of mountain streams in North Carolina decreased between the early 1960's and 1979. Mean hydrogen ion $\left(\mathrm{H}^{+}\right)$concentration of these streams was reported to 
have increased by $82 \%$ during this time period (Hendrey et al., 1980; Burns et al., 1981). The pH values of $90 \%$ of White Mountain streams in New Hampshire were said to have decreased between the late 1930's and 1979 with mean $\mathrm{H}^{+}$ concentration reported to have increased by $247 \%$ (Hendrey et al., 1980; Burns et al., 1981).

Lakes and streams in the mountains were thought to be the "canaries in the coal mine" that herald the impending doom of more lowland terrain composed of highly siliceous, granitic-type bedrock. Acidic deposition was believed to capable of eventually wearing down the greater acid neutralizing capacity of the thicker lowland soils and regolith. Such geologic materials were stated to have "relatively" few bases with which to neutralize deposition of acid (Braekke, 1976; Oden, 1976; Likens et al., 1979; Overrein et al.., 1980; U.S.EPA, 1980a,b; 1984; Bridge and Fairchild, 1981; Loucks et al., 1982; NAPAP, 1984). For example,

"Declines in pH and alkalinity (a measure of acid-neutralizing capacity) were first described in scandinavian lakes characterized as nutrient poor, surrounded by thin (or no) soils underlain by granite, with steep slopes. From the chemical changes observed, it appeared that in such lakes acid deposition consumed the acid-neutralizing capacity of the watershed and the associated water bodies to a point at which acidification could occur. In systems with such limited acid neutralization capacity (or sufficiently acid soils) it is believed that once the neutralization capacity is reduced, surface water quality will resemble precipitation chemistry within years to decades" (NAPAP, 1984, p.15).

As NAPAP began its research efforts, reports of widespread and profound damage to aquatic resources continued to emerge. The Northeast Acid Rain Task Force predicted that $44 \%$ of connecticut's lakes and about $60 \%$ of Massachusetts' reservoirs would be acidified if acidic deposition was not stopped (Bridge and Fairchild, 1981). The Institute of Ecology in Indiana placed these figures at essentially $100 \%$ (Loucks et al., 1982). The U.S. 
Fish and Wildlife Service Survey of six New England states claimed that $64 \%$ of waters surveyed having historical pH data and $70 \%$ having historical alkalinity data had recently become more acidic, presumably due to acidic deposition (Haines and Akielaszak, 1983). These figures were said to agree well with the prediction of $70 \%$ acidification based on sulfuric acid titration of alkalinity using contemporary water chemistry data (Henriksen, 1980) gathered in this survey (Haines and Akielaszak, 1983).

Because of such studies and statements, there was an incontrovertible belief in the 1970's and early 1980's that acidic deposition was rapidly creating an aquatic "silent spring". To quote Terry Haines (U.S. Fish and Wildlife Service) discussion of New England waters:

"In these acid ( $\mathrm{pH}<5$ ) lakes, fish populations are either absent or are maintained by stocking... . In the other lakes, the $\mathrm{pH}$ is not yet critically low, but the lakes are very low in alkalinity or buffering capacity and will not be able to resist acid precipitation for very long." (Congressional Committee on Energy and Commerce, 1982, p. 121).

Another example are the words of Frederick Johnson of the Pennsylvanian

Fish Commission:

"Fisheries people have been justifiably accused of bemoaning the increased losses, to their resource without suggesting acceptable solutions. I wish that it were possible for me to counter this tendency, but doubt that the tools are available to do so. But I do know that the industry stance to continue to research for another ten years, and do nothing else, is a formula to insure increasing degradation for the next 10-20 years. The clock is ticking out on trout, salmon, and many bass lakes and streams in our Northeast, parts of Canada and much of Northern Europe and Scandinavia. MOST OF THE PROPOSED RESEARCH WOULD ONLY FURTHER PROVE WHAT IS ALREADY KNOWN. (Emphasis added). The National Academy of Science reported in September 1981 that the evidence linking acid rain to atmosphere emission of fossil fuels and metal smelters in 'overwhelming'. Must we have a smoking gun and a warm corpse before we take action to discourage murder?" (Congressional Committee on Energy and Commerce, 1982, p. 93). 
The widespread acidification of surface waters was reported by scientists to coincide spatially and temporally with the reported spreading of acidic deposition:

"Scandinavian and North American studies appear to agree on one point: acidification of sensitive waters is detectable within one to two decades where $\mathrm{pH}$ values of precipitation are less than $4.6-$ a 10-fold increase in acidity over the theoretically 'pure' rain $\mathrm{pH}$ value of 5.6 (Henriksen 1979, 1980; Watt et al., 1979; Thompson et al.,1980)" (National Research Council, 1981, p.153).

The U.S. EPA, the lead federal agency responsible for the aquatic effects part of NAPAP, published the bulletin, "Acid Rain" (U.S.EPA, 1980a) which stated, "It is in lakes and streams where the most dramatic effects of acid rain have been clearly observed" (U.S. EPA, 1980a, p.14). The Bulletin then went on to quote statistics on how large numbers of Scandinavian lakes had $\mathrm{pH}$ decrease by almost $2 \mathrm{pH}$ units since the 1930's and how the percentage of $\mathrm{pH}$ less than 5 lakes and ponds at high altitudes greatly increased since the 1930's. "The acid rain condition in the 'forever wild' Adirondacks underlines the problem posed by the transport of pollutants from the point of their creation to the point of their effect" (U.S. EPA, 1980a, p.7).

"The extent of change in acidity of a lake or stream is determined mainly by the buffering capacity of the surrounding soil and the composition and size of the watershed in which the water resides. If the watershed soil is alkaline - containing limestone or bicarbonate to neutralize incoming acids - the lakes and streams will be far less susceptible to harm" (U.S. EPA, 1980a, p.14).

In 1980, the U.S. EPA also started to publish a newsletter-type status report, "Acid Rain". The newsletter begins,

"Acid rain is a major environmental problem on both sides of the Atlantic Ocean. Originally noticed and studied in the Scandinavian countries and Canada, acid rain has been documented in this country, first in the Northeast and now throughout much of the United States. Increasing levels of acidity have already caused measurable damage to the environment. Many lakes are now totally devoid of fish."

"A growing body of evidence suggests that acid rain may have $2-12$ 
substantial adverse effects on the environment. Such effects include acidification of lakes, rivers, and groundwaters, with resultant damage to fish and other components of the aquatic ecosystem."

"Fresh water bodies in much of eastern North America and northern Europe, which today lie within and adjacent to the areas of highest acidic rains, are threatened by the continual deposition and further expansion of acid rain. Most of these bodies of water are in regions underlain by carbonate-poor granitic rock and are poorly buffered and vulnerable to acid inputs. The increasing acidity of lakes in North America and Europe has been documented, with the most tangible result being the decline in fish populations. During the last 40 years, the mean $\mathrm{pH}$ of lakes in acid rain affected areas has decreased almost two units. This has led to a decrease in populations of fish and other aquatic organisms" (U.S. EPA, 1980b, p.1).

In summary, this chapter briefly reviews the background to the evolution of scientific thought concerning acid rain and its aquatic effects up through the inception of NAPAP. Acidic $\mathrm{H}_{2} \mathrm{SO}_{4}$ deposition was seen to expand out of the industrial and urban centers of western Europe after the second World War. Regional acidic deposition in western and northern Europe apparently achieved its approximate present distribution and intensity in the 1970's. The deposition chemistry of eastern North America was thought to have undergone a similar evolution. Numerous studies reported that acidification of surface waters was occurring in spatial and temporal coincidence with acidic $\mathrm{H}_{2} \mathrm{SO}_{4}$ deposition. Increasing acidity of surface waters was reported to be represented by decreasing concentrations of alkalinity and increasing concentrations of sulfate, presumably due to increased deposition of sulfuric acid. Thus, during the inception and early formative years of NAPAP, aquatic acidification had been reported to be an especially severe consequence of "acid rain".

From its inception, acid rain research has mostly accepted the premise that atmospheric deposition of sulfuric acid is responsible for widespread and profound chronic acidification of surface waters. 
The following chapter will examine the scientific credibility of this premise through comprehensive and critical examination of processes, causes, effects, theory, and hypotheses of surface-water acidification. 
CHAPTER 3

ACIDIFICATION OF SURFACE WATERS: DIRECT OBSERVATIONS, THEORY, AND HYPOTHESES

Processes and factors of surface-water acidification that are reported as representing the scientific consensus are presented in this report as the theory of surface-water acidification, or simply as acidification theory. Processes and factors of surface-water acidification that are outside of the reported scientific consensus are defined in this report as being alternative hypotheses of surface-water acidification, or simply acidification hypotheses. These processes and factors, unlike those of acidification theory, are not well researched and are not recognized as being important by most scientists in the aquatic effects research area.

Acidification theory assumes that, in the absence of acidic deposition, water chemistry of "sensitive" watersheds is geologically controlled. Their natural water chemistry is believed to be the product of carbonic acid $\left(\mathrm{H}_{2} \mathrm{CO}_{3}\right)$ weathering of mineral bases (e.g., $\left.\mathrm{Ca}^{2+}\right)$, which produces alkalinity $\left(\mathrm{HCO}_{3}{ }^{-}\right)$, e.g., $\mathrm{Ca}^{2+}+\mathrm{HCO}_{3}{ }^{-}$. Thus, the fundamental premise of acidification theory is that most waters currently more acidic than predicted on the basis of carbonate chemistry have been recently acidified by acidic $\mathrm{H}_{2} \mathrm{SO}_{4}$ deposition.

The alternative hypotheses of acidification recognize that the water chemistry of most currently "acidic" surface waters in "sensitive" watersheds is not now geologically controlled, nor, in their undisturbed state, were they likely to be geologically controlled in pre-deposition times. Such lakes and streams receive disproportionately large amounts of their water 
from highly acidic, organic-rich soils and peats and/or acidophilic ecosystems that mantle "sensitive" watersheds. The alternate hypotheses of acidification assume that most currently "acidic" surface waters in "sensitive" watersheds have been acidic in pre-deposition times due to weak organic acids and/or strong acidity produced by soil and plant processes. Thus, the fundamental premise of alternative hypotheses of acidification is that acidification by "acid rain" is superimposed upon natural processes of acidification. They predict that the principal effect of acidic deposition is the qualitative shift in the nature of acidity, rather than the massive quantitative increase in acidity predicted by acidification theory.

This chapter is divided into nine categories of observations from which the theory and alternative hypotheses of surface-water acidification have been developed:

3.1 Recorded changes in surface-water chemistry over time;

3.2 Documented declines in fisheries over time;

3.3 The distribution of acid-stressed and absent fish populations in relation with the distribution of acidic deposition or acidic waters;

3.4 The correlation of soil acidity with climate and acidic deposition;

3.5 current surface-water chemistry;

3.6 Non-steady state watersheds: Land-use changes and natural processes;

3.7 Field and laboratory experiments;

3.8 Paleolimnological investigations, and;

3.9 Observations of naturally-acidic waters associated with acidic soils not exposed to man-made acidic deposition.

Some of the more salient reported observations and conclusions regarding the nature and extent of surface-water acidification will be stated and critically examined. 


\subsection{Recorded Changes in Surface-Water Chemistry}

3.1.1 Comparison of Historical and Modern Water Chemistry Data

Wright (1977) obtained historical pH values for 87 Norwegian lakes for the period 1923 - 1949 with which to compare with recent pH measurements (Overrein et al., 1980). Overall, Wright (1977) compared modern and historical water chemistry data for 258 Norwegian and Swedish lakes. Wright (1977) reported that $63 \%$ of these lakes had become more acidic (i.e., recorded decreases in $\mathrm{pH}$ of more than 0.25$)$. Nine lakes have large decreases in recorded pH - 1.25 to almost $2 \mathrm{pH}$ units decrease (Wright, 1977; Overrein et al., 1980). Wright (1977) claimed that,

"all the lakes that have become more acidic are located in areas of southern Scandinavia that receive acid precipitation today (annual mean $\mathrm{pH}$ less than 4.6)"

as shown in Figure 3. He thereby concluded that acidic deposition was responsible for the decreases in $\mathrm{pH}$. This is the earliest use of mean annual precipitation $\mathrm{pH} 4.6$ to define areas of acidified surface waters (Wright, 1977) and, with subsequent reiterations (Wright et al., 1977; Wright and Henriksen, 1978), it is the origin of the belief that acidification of surface waters has occurred only in the last 40 years and only in areas receiving mean $\mathrm{pH} \leq 4.6$ precipitation (e.g., Galloway et al., 1978; Overrein et al., 1980; U.S. EPA, 1980a,b; 1984; National Research Council, 1981; Johnson et al., 1984; NAPAP, 1984; Reuss et al., 1987; Reuss, 1988; Sullivan et al., 1988).

Examination of Wright's (1977) original data show that 8 of the 9 lakes with large changes in recorded $\mathrm{pH}$ (of up to almost $2 \mathrm{pH}$ units) are located in Rondane National Park (Figure 3). The large change in $\mathrm{pH}$ for the ninth lake 


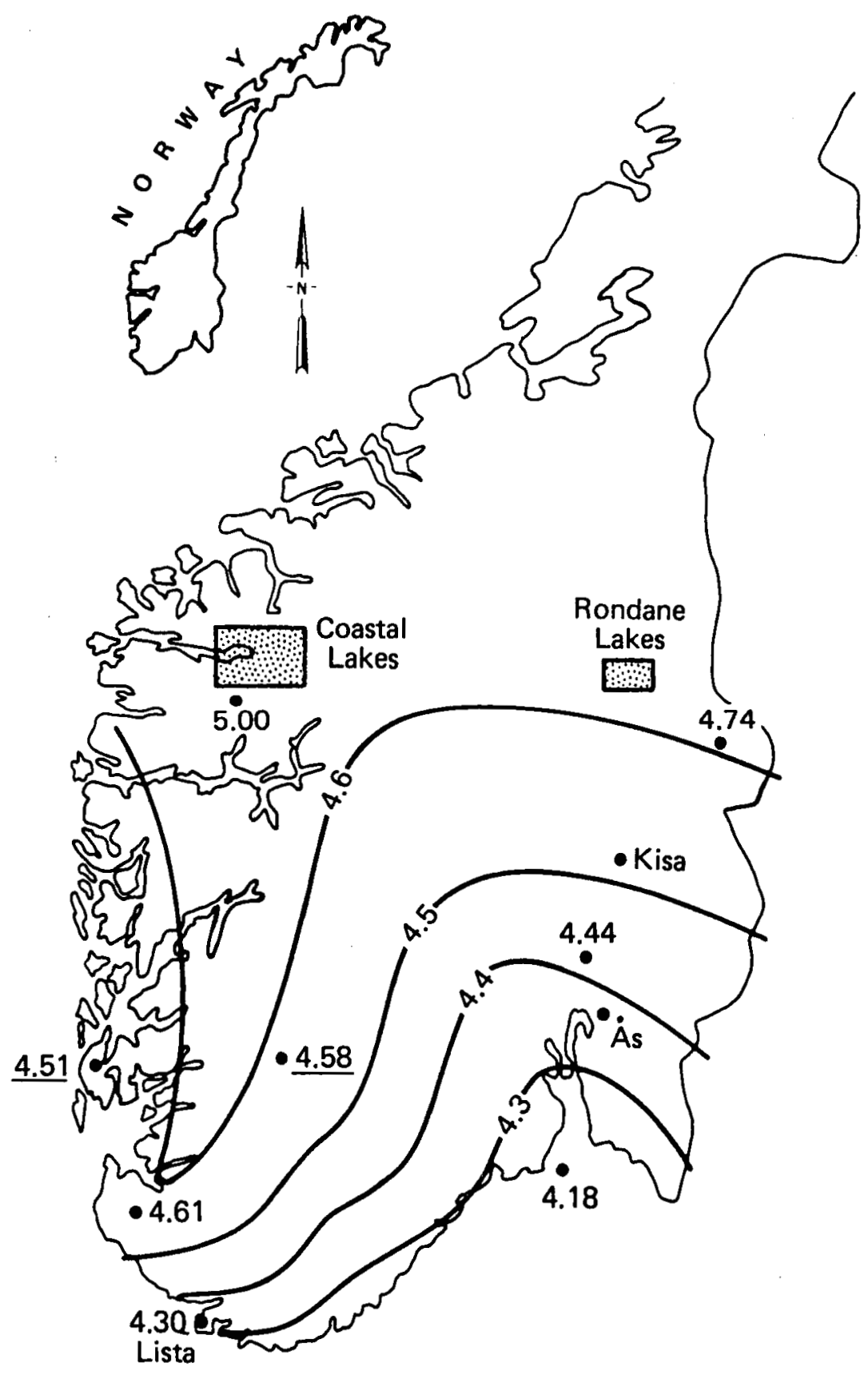

Figure 3. Distribution of mean annual precipitation pH for southern Norway (1972-1975) in relation to the locations of some lakes recorded to have been acidified over a forty year period. Modified from Braekke (1976) and Wright (1977).

$$
\text { 3-4 }
$$


was subsequently discounted as being seasonally influenced by alkaline runoff from a glacier (Overrein et al., 1980). Wright's map of the distribution of mean precipitation $\mathrm{pH}$ for southern Norway (Figure 3) shows that the Park lies outside of the $\mathrm{pH} 4.6$ precipitation area, not inside of it. The 5 lakes in Wright's data set that lie just north of the highest mean annual precipitation $\mathrm{pH}$ site in Norway, about $\mathrm{pH}=5.0$ (Figure 3), underwent a mean change in $\mathrm{pH}$ of -0.8 units (Wright, 1977).

Most of the 20 lakes outside of the $\mathrm{pH} \leq 4.6$ region underwent marked acidification. The magnitude of recorded $\mathrm{pH}$ change was greater for the lakes that are located outside of the "acid rain" area relative to those that were receiving highly acidic deposition. Also, the percentage of lakes that underwent acidification was greater for those lakes outside of the mean precipitation pH 4.6 area compared to those receiving highly acidic (pH less than 4.6) precipitation.

In view of this evidence, the widely-accepted conclusion that acidic $(\mathrm{pH}<4.6)$ precipitation is responsible for the recorded acidification of Scandinavian surface waters over the last 40 years (Wright, 1977) does not pass critical examination and is not scientifically credible.

Subsequent to the acidification study of Wright (1977), it became questionable to use old, historical water $\mathrm{pH}$ and alkalinity data to estimate temporal acidification of surface waters. The SNSF-Project concluded that trends in acidification reported by comparison of historical versus modern water chemistry data are unreliable due to errors inherent to differences in methodology and the general unreliability of earlier measurements (Overrein et al., 1980). Likewise, the National Research Council (1981) concluded,

"Routine surveys in the past have used measurement techniques too insensitive to detect changes in lakes susceptible to acidification." 
(National Research Council, 1981, p.152).

Nevertheless, after discounting the comparison of historical and modern water chemistry data in regard to surface-water acidification, on the very next page the National Research Council (1981, p. 153) does not discount the result of such comparison:

"Scandinavian and North American studies appear to agree on one point: acidification of sensitive waters is detectable within one or two decades where $\mathrm{pH}$ values of precipitation are less than 4.6..." (National Research Council (1981, p. 153).

The Final Report of the SNSF-Project makes similarly internallyinconsistent claims regarding recent recorded changes in acidity of surface waters in respect to recent changes in acidity of precipitation (Overrein et al. , 1980).

Re-examination of methodologies used to measure $\mathrm{pH}$ values of surface waters illustrates the problem faced by Norwegian and other scientists in comparing historical and modern water $\mathrm{pH}$ values. The old methods of $\mathrm{pH}$ and alkalinity measurement involve addition of chemicals to water samples and visual interpretation of color developed by the added chemicals. These added chemicals are nearly neutral in pH (Kramer and Tessier, 1982). However, "sensitive" waters of interest are exceedingly dilute and, therefore, have such low buffering capacity that the measured pH values of such waters tend to assume the $\mathrm{pH}$ values of the chemicals added (Kramer and Tessier, 1982).

For example, Schofield (1976) reported that survey of high altitude Adirondack lakes and ponds underwent widespread acidification: in the 1930's $4 \%$ of these waters had recorded $\mathrm{pH}$ values of less than 5 and in the 1970's over 50\% had recorded pH<5.0. Pfeiffer and Festa (1980) re-analyzed high altitude Adirondack lakes and ponds using both the old colorimetric and the 
modern meter methods of $\mathrm{pH}$ measurement. For the same lakes measured, the colorimetric method determined that $9 \%$ are $\mathrm{pH}<5.0$ and the meter method determined that over $50 \%$ are $\mathrm{pH}<5.0$. Whether the $9 \%$ figure is statistically different from the $4 \%$ figure for $\mathrm{pH}<5$ lakes found in the 1930's was not reported as having been determined (Pfeiffer and Festa, 1980).

Pfeiffer and Festa (1980) reported that the difference between pH values obtained colorimetrically and by $\mathrm{pH}$ meter increased with water acidity: being $1.5 \mathrm{pH}$ units for the most acidic (lowest $\mathrm{pH}$ ) lakes. That the addition of a neutral chemical buffer to dilute water will result in larger upward shifts in $\mathrm{pH}$ for the more acidic (lower $\mathrm{pH}$ ) waters is well predicted by chemical principles (Kramer and Tessier, 1982).

Kramer and Tessier (1982) report that old and new analyses, even if performed by the same methods, are likely to differ because the materials and chemicals of today are different or are of different purity. And this difference is likely to be biased to artificially represent recent increases in the acidity of water (Kramer and Tessier, 1982). For example, we now use unreactive plastic and special glass sampling containers. Up into the 1960's, glass containers that leached alkalinity into water samples were widely used. In the 1960's, Standard Methods of water analyses recognized this problem and recommended the use of non-reactive plastic or special glass containers to overcome this type of systematic error (Kramer and Tessier, 1982). Thus, it is not unreasonable to expect that colorimetric pH values determined in 1980 may yield somewhat more acidic $\mathrm{pH}$ values than it would in the 1930's.

More recently, Kramer et al. (1986) used critical and rigorous chemical analyses and protocols to re-analyze New York and New Hampshire historical 
water data and compare the corrected data to modern data. Uncorrected data indicated marked acidification. However, essentially no acidification trend was reported for the corrected data (Kramer et al., 1986).

Burns et al. (1981) and Haines and Akielaszak (1983) compared incompatible historical and contemporary water chemistry data to report observed acidification trends. Burns et al. (1981) recognized the incompatibility of at least the alkalinity water chemistry data and claimed that the correction factor for comparing the methyl-orange and Gran titration alkalinity endpoints is $32 \mathrm{ueq} / \mathrm{L}$, "the amount of free $\mathrm{H}^{+}$in solution at $\mathrm{pH} 4.5^{\prime \prime}$ (Burns et al., 1981).

Burns et al. (1981) underestimated the acidification bias inherent by comparison of methyl-orange and Gran titration alkalinity. The actual theoretical difference between Gran titration and methyl-orange endpoint measurements of alkalinity for true carbonate systems is 82 ueq/L (Kramer and Tessier, 1982).

The publication of Dillon et al. (1978) appears to be the earliest scientific claim for acidification of a Canadian surface water (Clear Lake) by regional acidic deposition. It has been prominently cited as one of the definitive studies to have documented that acidic deposition is solely responsible for acidification of surface water (National Research Council, 1981; Krug and Frink, 1983a; Havas et al.. 1984; U.S. EPA, 1984).

Alkalinity of Clear Lake was measured by titration to $\mathrm{pH} 4.5$ endpoint and not by Gran titration (Dillon et al., 1978). By the time of the Dillon et al. (1978) study, Standard Methods for the Examination of Water and Wastewater (APHA, 1971) - which is the "Bible" for the analysis of waterreported that the $\mathrm{pH} 4.5$ endpoint method is too insensitive and is 
inappropriate for measurement of alkalinity of waters as dilute as that of Clear Lake. This fact also became recognized in the acid rain literature (Overrein et al., 1980; Burns et al., 1981; National Research Council, 1981; Kramer and Tessier, 1982). The values for both historical (33 ueq/L) and modern (2-15 ueq/L) alkalinities for Clear Lake and their difference (Dillon et al., 1978) are about equal to or less than the estimated error of measurement (APHA, 1971; Kramer and Tessier, 1982). Even if the reported values of the titration were accurate, these values can not represent bicarbonate $\left(\mathrm{HCO}_{3}{ }^{-}\right.$) alkalinity (APHA, 1971; Kramer and Tessier, 1982).

Subsequent Canadian reports have also claimed to have demonstrated regional acidification of surface waters by acidic deposition. Thompson et al. (1980) reported that measured pH values for 3 Nova Scotian rivers between 1954-1955 and 1965-1973+ had decreased as the result of increased acidic deposition. Also, they reported that the gradient in acidity of river water paralleled that of acidic deposition which suggests a spatial as well as temporal relationship between acidity of water and precipitation (Thompson et al., 1980). While Thompson et al. (1980) did not comment on methods of analysis, they did mention that the old water chemistry data were obtained from samples stored at room temperature (Thompson et al., 1980) which is a practice no-longer considered acceptable by aquatic chemists. Again, the issue of quality of old versus modern water chemistry data for measurement of acidity makes comparison of such data questionable (Kramer and Tessier, 1982).

The correlation of northeast/southwest acidity gradients between acidic deposition and river water in mainland Nova Scotia does not necessarily establish a causal relationship. For mainland Nova Scotia, there is also a 


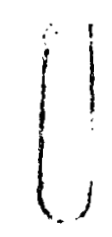

interspersed with thin, highly acidic peaty soils overlying granitic rock. Going north, the land becomes better drained. There are fewer bogs, the landscape is mantled with a higher proportion of deep, well drained mineral soil (Fernow, 1912; Goldthwait, 1924). Thus, it is expected that waters of the southwest would tend to be naturally more acidic and organic rich because more runoff is coming from acidic organic soil materials and peats (Krug and Frink, 1983a,b; Gherini et al., 1985). Such waters are expected to contain relatively higher concentrations of DOC (dissolved organic carbon), which is commonly used as a surrogate for natural onganic acids. Waters of the northeast are expected to be more geologically controlled (i.e., having greater amounts of alkalinity and base mineral cations produced by mineral weathering) .

The influence of physiography on Nova Scotian river water chemistry is apparent from the more recent and comprehensive data of Thompson (1986) in Table 1. The southwest tends to have the acidic $(\mathrm{pH}<5.5)$ rivers which are relatively higher in $\mathrm{DOC}$ and lower in $\mathrm{SO}_{4}{ }^{2-}$ than the $\mathrm{pH} \gg 5.5$ rivers of the northeast (Table 1). The northeastern rivers have alkalinity and also tend to have somewhat higher concentrations of $\mathrm{SO}_{4}{ }^{2-}$.

These Nova Scotian river-water data (Table 1) do not support the belief that their acidity and geographic distribution of acidity are principally due to acidic $\mathrm{H}_{2} \mathrm{SO}_{4}$ deposition. The acidity of Nova Scotian rivers appears to be strongly related to natural watershed processes, as predicted by alternative hypotheses of acidification.

Watt et al. (1979) have claimed that acidic $\mathrm{H}_{2} \mathrm{SO}_{4}$ deposition is 


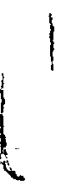

Table 1. Some Water Chemistry Data for Nova Scotian Rivers.

\begin{tabular}{lcccc}
\hline River & $\mathrm{n}$ & $\mathrm{pH}$ & $\begin{array}{c}\mathrm{DOC} \\
(\mathrm{mg} / \mathrm{L})\end{array}$ & $\begin{array}{c}\mathrm{SO}_{4}^{2 .} \\
(\mathrm{mg} / \mathrm{L})\end{array}$ \\
\hline Roseway & 10 & 4.4 & 13.4 & 1.9 \\
Tusket & 10 & 4.6 & 11.0 & 2.7 \\
Liscomb & 11 & 4.8 & 9.2 & 1.7 \\
Mersey & 27 & 5.0 & 8.4 & 1.9 \\
Medway & 12 & 5.4 & 6.7 & 1.7 \\
Kelley & 11 & 5.6 & 6.4 & 2.6 \\
Meteghan & 17 & 5.7 & 9.1 & 2.7 \\
La Have & 11 & 5.9 & 6.4 & 2.8 \\
St. Marys & 10 & 6.0 & 4.6 & 1.7 \\
Clam H. & 9 & 6.1 & 6.0 & 2.2 \\
Wallace & 9 & 6.8 & 3.8 & 2.8 \\
\hline
\end{tabular}

From Thompson (1986). Data for 1983. 
responsible for the regional acidification of "undisturbed" Nova Scotian lakes. Their study has been prominently cited as proving that acidic $\mathrm{H}_{2} \mathrm{SO}_{4}$ deposition is solely responsible for the acidification of Nova Scotian lakes (e.g., National Research Council, 1981; Havas et al., 1984; U.S. EPA, 1984).

Critical examination of the watt et al. (1979) reveals internal inconsistency. The data do not support the conclusion drawn from them. For example, concentration of $\mathrm{H}^{+}$increased by $21 \mathrm{ueq} / \mathrm{L}$ for "undisturbed" lakes on granite but concentration of non-marine $\mathrm{SO}_{4}{ }^{2-}$ increased by only 9 ueq/L (Gorham, 1957; Watt et al., 1979). It is only possible for $9 \mathrm{ueq} / \mathrm{L}$ of $\mathrm{H}_{2} \mathrm{SO}_{4}$ to contribute $9 \mathrm{ueq} / \mathrm{L}$ of $\mathrm{H}^{+}$to water, not $21 \mathrm{ueq} / \mathrm{L}$. Even if all non-marine $\mathrm{SO}_{4}{ }^{2-}$ represented addition of pure $\mathrm{H}_{2} \mathrm{SO}_{4}$ to lakewater, the maximum increase in concentration of $\mathrm{H}^{+}$that is possible is $9 \mathrm{ueq} / \mathrm{L}$, not $21 \mathrm{ueq} / \mathrm{L}$ as reported (Watt et al., 1979). Assuming that the data of Watt et al. (1979) is accurate, then some factor other than acidic $\mathrm{H}_{2} \mathrm{SO}_{4}$ deposition must be the principal factor responsible for the reported increase in acidity of Nova Scotian lakes.

In summary, this section has critically examined Scandinavian, Canadian, and American studies reporting that recorded historical acidification of surface waters is correlated both spatially and temporally to the advent of acidic deposition and is, therefore, caused by acidic deposition. These reviewed studies have been seminal to the reported scientific consensus established during the pre- and early-NAPAP years that acidic deposition is mainly, or even solely responsible for the widespread and recent acidification of surface waters (e.g., Galloway et al., 1978; Overrein et al., 1980; U.S. EPA, 1980a,b; 1984; National Research Council, 1981). critical examination shows that such a conclusion is not scientifically 
credible. All of the examined studies suffer from significant inconsistencies and do not comprehensively consider relevant factors. These errors are not random. They consistently err on the side of overestimating surface water acidification by acidic $\mathrm{H}_{2} \mathrm{SO}_{4}$ deposition. 


\subsubsection{Recorded Trends in Water Chemistry}

Data from the Swedish atmospheric deposition and hydrochemical monitoring networks (the latter started during the International Hydrological Decade, 1965 - 1975), have been reported to show trends and regional differences in river-water chemistry due to acidic deposition. Oden (1976), in a keynote paper to the First International Symposium on Acid Precipitation and the Forest Ecosystem, reported that Swedish river-water chemistry data show a marked decrease in pH from 1965 onward, ranging from 8.5\% to $19.3 \%$ increase in the concentration of $\mathrm{H}^{+}$per year.

"If the slopes are extended to pH 5.5, which is supposed to be a biologically critical pH value a 'life-time of health' is obtained. On the average $60 \%$ of the investigated rivers in Sweden will reach this critical point in 40 years and as much as $90 \%$ in 80 years" (Oden, 1976).

oden also reported that concentrations of $\mathrm{HCO}_{3}{ }^{-}$are decreasing while concentrations of $\mathrm{SO}_{4}{ }^{2-}$ are increasing in Swedish rivers (Oden, 1976), with river discharge of $\mathrm{SO}_{4}{ }^{2-}$ increasing by 2\% to 5\% per year from 1965 to 1977 (Oden, 1979). Oden $(1976 ;$ 1979) stated that there are corresponding north/south gradients in precipitation and river-water chemistry with concentrations of $\mathrm{SO}_{4}{ }^{2-}$ being highest in the south. He estimated that acidic $\mathrm{H}_{2} \mathrm{SO}_{4}$ deposition has increased river-water concentrations of $\mathrm{SO}_{4}{ }^{2-}$ in southern Sweden 10-fold over background levels (Oden, 1976; 1979). Oden's (1976; 1979) reports are considered to be an influential and historicallysignificant contribution to the scientific understanding of the aquatic effects of "acid rain" (Cowling, 1980; 1982).

Data from the Swedish atmospheric deposition and hydrochemical monitoring programs do not support oden's (1976; 1979) claims that trends and regional 
differences in river-water chemistry are due to acidic deposition. For example, Sanden et al. (1987) report that using the data from the same hydrochemical network used by Oden $(1976 ; 1979)$, at the $5 \%$ level,

"For stream water quality, 100 trend tests gave 7 statistically significant results, and this barely exceeds the number of significant results that could be expected to occur by chance. At the $1 \%$ level, no water quality trends at all could be verified."

Data tested for trend analysis were $\mathrm{pH}$, alkalinity, $\mathrm{Ca}^{2+}, \mathrm{Mg}^{2+}, \mathrm{SO}_{4}{ }^{2-}$, and alkalinity-to-hardness ratio (Sanden et al., 1987).

Sanden et al. (1987) also reported:

"The difference between wet deposition of $S$ in southern and northern parts of Sweden was found to be smaller than previously reported. In the northern catchment areas, the input of $S$ was considerably larger than output."

These data are presented in Table 2.

Oden's (1979) sulfur budget publication was one of three articles related to the sulfur chemistry of Scandinavian surface waters that appeared virtually in sequence in the same issue of Nordic Hydrology. One of the other two articles (Anderson-Calles and Eriksson, 1979) directly refutes Oden's (1979) conclusions for the same reasons cited by Sanden et al. (1987). Iike Sanden et al. (1987), Anderson-Calles and Eriksson (1979) also use data from the same Swedish atmospheric deposition and hydrochemical monitoring networks used by both Oden $(1976 ; 1979)$.

Anderson-Calles and Eriksson (1979) show that deposition of $\mathrm{SO}_{4}{ }^{2-}$ by precipitation in Sweden is not much different from north-to-south (Table 2). What is apparently different, on a regional basis, is the geochemistry of sulfur in watersheds. Anderson-Calles and Eriksson (1979) note that the more northern parts of Sweden's relatively level landscape are fairly waterlogged (Anderson-Calles and Eriksson, 1979), which suggests that 
Table 2. Wet Deposition of $\mathrm{SO}_{4}{ }^{2-}$ and Discharge of $\mathrm{SO}_{4}{ }^{2-}$ for Swedish Rivers by Region.

\begin{tabular}{lcccc}
\hline Region & $\begin{array}{r}\text { Precipitation } \\
(\mathrm{kg} / \mathrm{ha}-\mathrm{yr})\end{array}$ & $\begin{array}{c}\text { Discharge }^{*} \\
(\mathrm{~kg} / \mathrm{ha}-\mathrm{yr})\end{array}$ & $\begin{array}{c}\text { Precipitation }^{+} \\
(\mathrm{mg} / \mathrm{L})\end{array}$ & $\begin{array}{c}\text { Discharge }^{+} \\
(\mathrm{mg} / \mathrm{L})\end{array}$ \\
\hline North $\left(>65^{\circ}\right)$ & 23.52 & 10.77 & 3.89 & 4.55 \\
Central $\left(60^{\circ} \mathrm{N}-65^{\circ} \mathrm{N}\right)$ & 27.06 & 11.10 & 3.70 & 5.69 \\
South $\left(<60^{\circ} \mathrm{N}\right)$ & 29.97 & 23.60 & 4.13 & 11.82 \\
\hline
\end{tabular}

*From Anderson-Calles and Eriksson (1979).

${ }^{+}$From Sanden et al. (1987). 
sulfate-reduction can be a prominent process in these terrains. This is further supported by the data in Table 2 showing that discharge of $\mathrm{SO}_{4}{ }^{2-}$ from watersheds in central and northern sweden is about half that of $\mathrm{SO}_{4}{ }^{2-}$ deposition and is considerably less than discharge of $\mathrm{SO}_{4}{ }^{2-}$ from southern Sweden.

That Anderson-Calles and Eriksson (1979), Oden (1976; 1979) and Sanden et al. (1987) all use data from the same monitoring networks and that AndersonCalles and Eriksson (1979) and Sanden et al. (1987) were able to factually support their conclusions (Table 2) raises questions about Oden's (1976; 1979) interpretation of these data.

An article by Salbu et al. (1979), "Elemental Composition of Norwegian Rivers." appeared in the same issue of Nordic Hydrology as did the publication of Anderson-Calles and Eriksson (1979) and Oden (1979). Unlike Sweden (Table 2), there is a tremendous north/south gradient in the concentration of $\mathrm{SO}_{4}{ }^{2-}$ in Norwegian precipitation (Figure 4). While southern Norway is influenced by polluted airmasses coming up from the south out of the heart of industrial Europe, central and northern Norway principally receive relatively unpolluted precipitation from the North Atlantic and Arctic Oceans (Johannessen, 1970). The mountainous Scandinavian divide that separates Norway and Sweden also influence air flow as well (Johannessen, 1970), apparently keeping much of the acidic deposition that falls throughout Sweden from falling on central and northern Norway.

Thus, while there is a marked difference in the north/south $\mathrm{SO}_{4}{ }^{2-}$ deposition gradient in Norway (Figure 4), there is little discernable north/south difference in the concentration of $\mathrm{SO}_{4}{ }^{2-}$ in rivers, although there are marked local differences in concentrations of $\mathrm{SO}_{4}{ }^{2-}$ in river water 


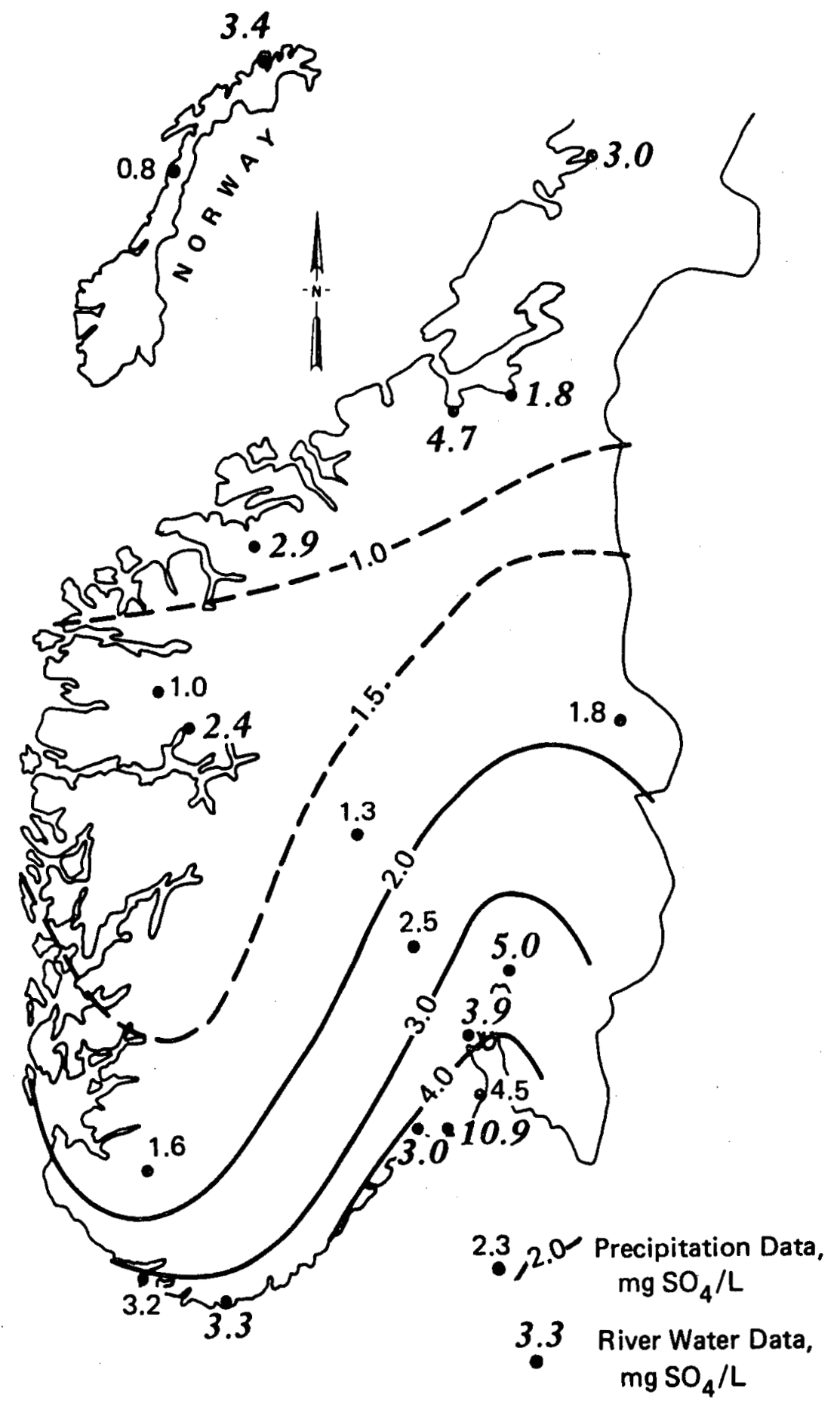

Figure 4. Mean annual concentrations of $\mathrm{SO}_{4}{ }^{2-}$ in Norwegian precipitation and river water. Precipitation data (1972-1975) are from Braekke (1976) and river-water chemistry data (1971) are from Salbu et al. (1979). 
(Figure 4).

In conclusion, reports of massive acidification of Swedish river by acidic $\mathrm{H}_{2} \mathrm{SO}_{4}$ deposition is not supported by data on either river water or deposition chemistry (Anderson-Calles and Eriksson, 1979; Sanden et al., 1987) used to generate this conclusion (Oden, 1976; 1979). Furthermore, data presented for Swedish and Norwegian precipitation and river-water chemistry suggest that atmospheric deposition is not necessarily the dominant factor influencing the sulfur chemistry of surface waters in Scandanavia as is widely asserted.

NAPAP's Interim Assessment (Malanchuk and Turner, 1987) reports that high quality data from U.S. Geological Survey benchmark stations on "undisturbed" headwater streams in the Northeast show that concentrations of stream $\mathrm{SO}_{4}{ }^{2-}$ are decreasing and concentrations of alkalinity are increasing. Thus, it is concluded that such streams are becoming less acidic in rapid response to recent decreases in regional emissions of $\mathrm{SO}_{2}$ and regional deposition of $\mathrm{H}_{2} \mathrm{SO}_{4}$ (Malanchuk and Turner, 1987). However, examination of the U.S. Geological Survey data shows that all four of the "undisturbed" Northeast headwater streams examined have $\mathrm{pH}$ values that are becoming increasingly more acidic (Smith and Alexander, 1983). That stream $\mathrm{pH}$ values are becoming more acidic in response to decreasing concentrations of $\mathrm{SO}_{4}{ }^{2-}$ (Smith and Alexander, 1983) does not support the conclusion that $\mathrm{SO}_{4}{ }^{2-}$ is controlling acidity of streamwaters (Smith and Alexander, 1983; Malanchuk and Tumer, 1987) .

McDonalds Branch in the New Jersey Pine Barrens is one of the four U. S. Geological Survey Northeast benchmark streams (Smith and Alexander, 1983; Campbell and Turk, 1988). McDonalds Branch has also been used to "prove" that acid rain is responsible for the increasing acidity of New Jersey Pine 
Barrens streams (A.H. Johnson, 1979; Campbell and Turk, 1988). Remarkably, the trend for decreasing $\mathrm{pH}$ at McDonalds Branch is the weakest of all Northeast streams (Smith and Alexander, 1983). The trend for decreasing $\mathrm{pH}$ is even more significant for all of the other streams (Smith and Alexander, 1983), which, along with McDonalds Branch, are said to be becoming less acidic (Smith and Alexander, 1983; Malanchuk and Turner, 1987; Campbell and Turk, 1988). Even though this is a terrible inconsistency in the literature, both arguements are being used as proof that acid rain is the principal actor controlling the acidity of these waters (A.H. Johnson, 1979; Smith and Alexander, 1983; Malanchuk and Turner, 1987; Campbell and Turk, 1988). However, such statements are logically self-invalidating.

It is chemically impossible for bicarbonate alkalinity $\left(\mathrm{HCO}_{3}{ }^{-}\right)$waters to have $\mathrm{pH}$ become more acidic while alkalinity is increasing. This is because pH and alkalinity are directly related to each other:

$\left[\mathrm{H}^{+}\right]\left[\mathrm{HCO}_{3}=\right]=10^{-6.38}:\left[\mathrm{H}_{2} \underline{\mathrm{CO}}_{3}\right]=10^{-1.47}$; for $\mathrm{POO} 2=10^{-3.5}$

$$
\left.\left[\mathrm{H}_{2} \mathrm{CO}_{3}\right]+\mathrm{P}_{2} \mathrm{CO}_{3}\right]=10^{-4.97}
$$

Therefore, $\left[\mathrm{H}^{+}\right]\left[\mathrm{HCO}_{3}^{-}\right]=10^{-6.38} \times 10^{-4.97}$, or

$\mathrm{pH}+\mathrm{pHCO}_{3}^{-}=6.38+4.97$, or

$\mathrm{pH}=11.35+\log \left[\mathrm{HOO}_{3}{ }^{-}\right]$.

A possible reason why "alkalinity" can be increasing while pH is decreasing is that "alkalinity" is not determined by Gran titration but by acid consumed to achieve a pH 4.5 endpoint. Because these streams are very dilute waters (Smith and Alexander, 1983), $\mathrm{HCO}_{3}^{-}$alkalinity is totally consumed by pH 5.0 (APHA, 1971; Tessier and Kramer, 1982). Thus what is being measured is not alkalinity, but an arbitrary measure of buffering capacity. A stream such as McDonalds Branch, which has a mean $\mathrm{pH}$ considerably less than 5.0 (A.H. Johnson, 1979; Smith and Alexander, 1983), 
has no alkalinity at all and yet it is said that its alkalinity is increasing (Smith and Alexander, 1983; Malanchuk and Turner, 1987; Campbell and Turk, 1988). And yet it, and the other streams are becoming more strongly buffered at more increasingly acidic $\mathrm{pH}$ values with time. A perhaps more correct chemical interpretation of these U.S. Geological Survey data (Smith and Alexander, 1983) is that total and free acidity are increasing because of increasing amounts of weak acid(s) which acts as both acidifier and buffer. In this way, streantaters can be becoming more strongly buffered at more acidic $\mathrm{pH}$ values while concentrations of $\mathrm{SO}_{4}{ }^{2-}$ are decreasing. Thus some agent, such as organic acids, may be more strongly buffering these waters at increasingly more acidic pH values with time.

In conclusion, some other process(es) is overwhelming any possible effect that acidic $\left(\mathrm{H}_{2} \mathrm{SO}_{4}\right)$ deposition can be having on acidity of "undisturbed" U.S.G.S. Northeast benchmark headwater streams. These streamwater chemistry data do not scientifically support the claims being made from them (A.H. Johnson, 1979; Smith and Alexander, 1983; Malanchuk and Turner, 1987; Campbell and Turk, 1988).

In sumary, this section has critically examined some important Scandinavian and American trend studies instrumental in establishing and promulgating the reported scientific consensus that acidification of waters by acidic deposition is an especially severe problem on both sides of the Atlantic. Nevertheless, these studies do not pass critical examination and do not convincingly show that the claimed trends exist at all or that existing trends are related to acidic deposition. 


\subsection{Documented Declines in Fisheries over Time}

Declines in the salmon fisheries of rivers in southern Norway (Braekke, 1976) and Nova Scotia (Watt et al., 1983) have been documented and attributed solely to the recent onset of acidic deposition (Braekke, 1976; Watt et al., 1983). There has also been documented declines of fisheries in the Adirondacks (Pfeiffer and Festa, 1980; Retzsch et al., 1982; Baker and Harvey, 1984; Malanchuk and Turner, 1987). However, decline in Adirondacks fisheries are reported to be related to multiple factors such as increased fishing pressure, introduction of competitive fish populations, discontinuation of stocking programs of waters that were never able to develop self-sustaining fish populations, application of DDT that disrupted the food chain, and reported increasing acidity of water, among others (Pfeiffer and Festa, 1980; Retzsch et al., 1982; Baker and Harvey, 1984; Malanchuk and Turner, 1987).

Documentation of acidification-related fisheries declines in areas other than those mentioned above is reported to be scarce and not particularly accurate (Haines and Baker, 1986; Malanchuk and Turner, 1987).

Declines in salmon catch for seven acidic rivers in southern Norway have been reported to be due to the post World war II advent of acidic deposition (Braekke, 1976). Data from these seven acidic rivers have been compared to those of 68 other Norwegian rivers (Figure 5). Such comparison is said to reduce error associated with natural variations in salmon populations and human factors (other than acidic deposition) that influence fisheries catch (Braekke, 1976). Accordingly, acidic deposition is reported to be responsible for the loss of salmon from these acidic rivers (Braekke, 1976). 


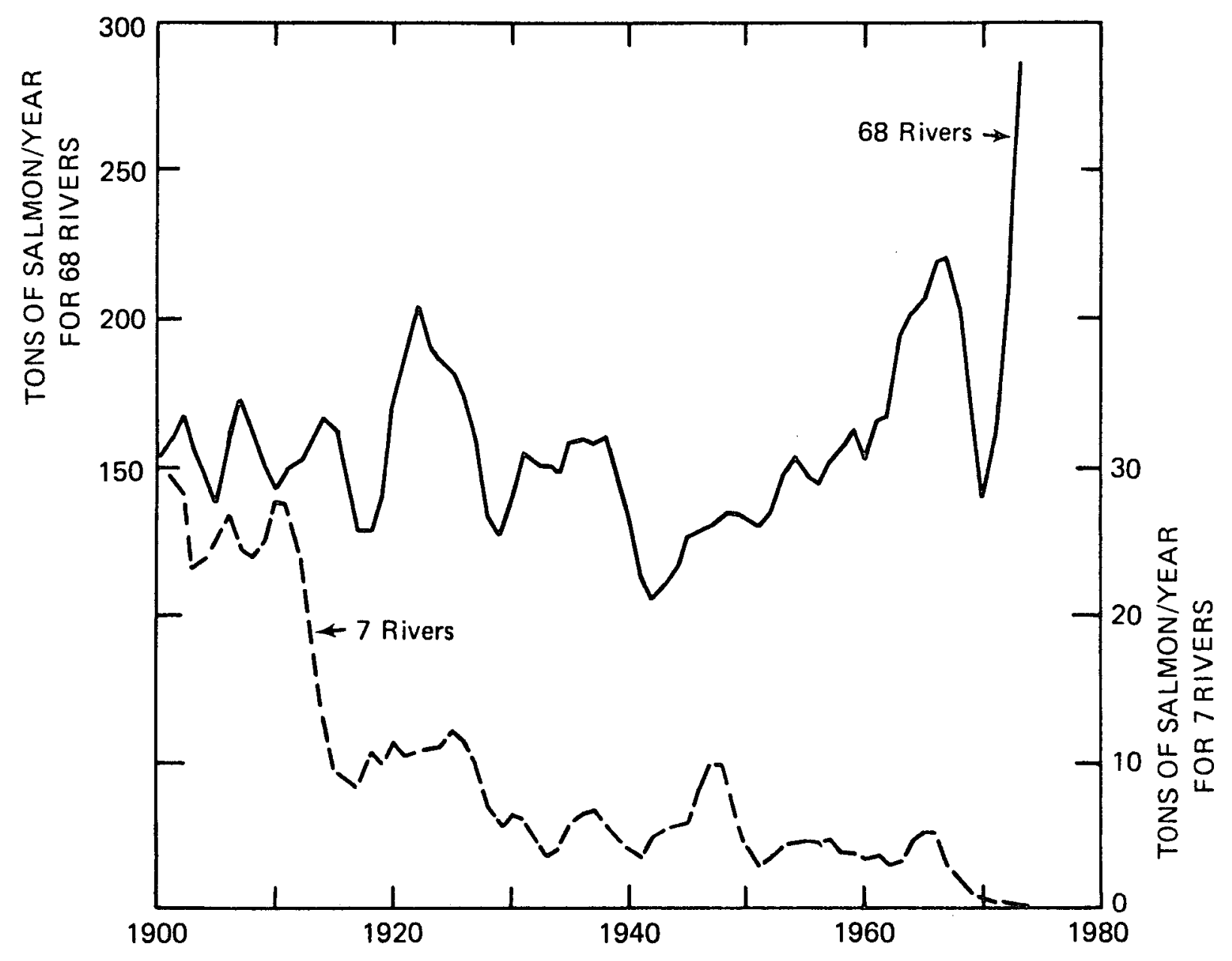

Figure 5. Comparison of historical salmon catch data for 7 Norwegian rivers that have lost salmon compared with 68 other Norwegian salmon rivers. Modified from Braekke (1976). 
Nevertheless, the salmon decline reported by the SNSF-Project (Braekke, 1976; Figure 5) does not agree with the onset of acidic deposition reported by the SNSF-Project (Braekke, 1976). The advent of acidic deposition in southern Norway is reported to be a 1960's phenomenon for the "affected" region (Braekke, 1976; Figure 1; 2). But most of the salmon in "affected" rivers were lost between 1910 and 1920 (Figure 5) with massive fishkills occurring after heavy rains and snowmelts as early as 1911 with autopsy results indicating mortality due to symptoms diagnostic of highly acidic waters (Braekke, 1976). Thus, while loss of salmon appear to be related to acidity, from the data on hand (Braekke, 1976), it can not be scientifically claimed that this problem is solely related to the recent onset of acidic deposition, as claimed.

There are at least two other possibilities to consider in regard to the loss of Norwegian salmon. One possibility is that comparably high rates of acidic deposition were achieved at least as early as 1900 in southern Norway and that acidic deposition is responsible for the very early loss of fisheries. This possibility would mean that there is a very large error in all of the atmospheric monitoring networks in Scandanavia and Europe that recorded the systematic expansion of regional acidic deposition in recent decades (Figure 1; 2). It would also mean that our fundamental understanding of chemistry and physics is incredibly flawed, as well as accounts of European industrial and environmental history (Chapter 2). The industrial heartland of Europe emitted considerable amounts of $\mathrm{SO}_{2}$ in the early twentieth century, but less than did post World War II Europe. These lesser amounts of early $\mathrm{sO}_{2}$ emissions were not emitted from tall smokestacks and were emitted along with alkaline particulates. Thus, it appears that these 
lesser amounts of early $\mathrm{SO}_{2}$ emissions were less subject to long-distance transport as $\mathrm{H}_{2} \mathrm{SO}_{4}$ than modern $\mathrm{SO}_{2}$ emissions because much of these emissions were being deposited locally (relatively poor disperse in the absence of tall smokestacks) and a higher proportion of these early $\mathrm{SO}_{2}$ emissions were neutralized by emitted particulates. After World war Two, industrial and energy demands achieved unprecedented levels necessitating a multi-pronged strategy to alleviate local air pollution problems that became so bad that they were outright killing people. The solution that was found to reduce these local air pollution problems was dilution (to disperse the pollutants over a greater airshed through the use of tall smokestacks) and the use of cleaner-burning fuels to reduce particulates. Accordingly, considerations of atmospheric chemistry, physics, European industrial and environmental history all support the recorded observations that current high levels of acidic deposition in southern Scandanavia were achieved within the last several decades and not nearly a century ago.

The other possibility regarding acidity-related fisheries problems is that acidic deposition is not the only agent capable of strongly acidifying surface waters. Rosenqvist $(1978 ; 1980)$ presented an alternative hypothesis of acidification, the operative factors of which can predate the recorded onset of acidic deposition. Rosenqvist's alternative hypothesis of surfacewater acidification resulting from land-use change will be subsequently discussed in Chapter 3.6.

Many scientists consider that regional acidic deposition and acidityrelated fisheries problems in Nova Scotia occurred after 1955 (Likens et al., 1979; Watt et al., 1979; Thompson et al., 1980; National Research Council, 1981; Havas et al., 1984). However, like Norway (Braekke, 1976; Rosenqvist, 
1978; 1980), documented acidity-related fisheries problems in Nova Scotia also date back to at least the early part of this century. Failures of fish populations and stocking efforts in these early years were reported to be related to lethally-high levels of acidity in water (Smith, 1938). Lakes 7 and 9 of Gorham's (1957) data set (on granitic watersheds) were neutralized and fertilized in 1947 and 1948 in hopes of developing successful fisheries in them. But lakes 7 and 9 quickly re-acidified. By 1955, they gave no chemical indications of treatment; the $\mathrm{pH}$ values of both lakes were around 4.5 and concentrations of calcium were down to low levels (Gorham, 1957).

The Nova Scotian lake data of Gorham (1957) cited as proving that acidification of Nova Scotian lakes and acidity-related fisheries problems became profound after 1955 (Watt et al., 1979) instead suggest that the magnitude of acidification of these Nova Scotian lakes may have been considerable and profound well before 1955. Gorham (1957) sampled 23 lakes in 1955 and found $\mathrm{pH}$ values lower than 5.0 for 10 of these 23 lakes ( 43\%). He found $\mathrm{pH}$ values as low as 3.95 (Gorham, 1957). Subsequently, in 1984, the U.S. EPA sampled over 1600 lakes in the eastern United States in regions considered to be sensitive to acidification by regional acidic deposition (Kanciruk et al., 1986). Most of these regions are experiencing high rates of acidic deposition (Kanciruk et al., 1986; Reuss et al., 1987). Nevertheless, only 75 of over 1600 lakes (4.7\%) were found to have $\mathrm{pH}$ values less than 5.0. Only 3 lakes of the over 1600 sampled had pH values less than 4.0, all of which are in the Florida sampling region (Kanciruk et al., 1986), a region said not to be receiving acidic deposition sufficient for marked acidification of surface waters (Likens et al., 1979; Reuss et al., 1987).

As with Norway, there are alternative possibilities for the early recorded 
dates of highly acidic, toxic waters in Nova scotia. There is the question of whether damaging acidic deposition came before 1955 or not. Unlike the Scandinavian and European situations, where there have been national and continent-wide monitoring networks continuously in operation for about 40 years, there was only one station in operation for a couple of years (19521954) in the 1950's. The quality of the data from this station has come under question (Kramer and Tessier, 1982).

On the other hand, even today, Nova Scotia is just at the edge of receiving regional acidic deposition severe enough to be considered a problem for chronic surface-water acidification (Reuss et al., 1987; Underwood et al., 1987). Mean annual precipitation $\mathrm{pH}$ of sites closest to North American centers of emissions (the southwest) are about pH 4.6 and at the other end of the province, about pH 4.9 (Underwood et al., 1987). Besides being far removed from major emission regions such as the Ohio Valley (distance between Halifax and Cincinnati is alittle over 1,100 miles or 1,800 kilometers) and southern Ontario (distance between Halifax and Sudbury is somewhat over 800 miles or about 1,300 kilometers), Watt et al. (1979) noted that Nova Scotia receives significant amounts of but slightly polluted air and precipitation off the Atlantic Ocean. Thus, it is possible that regional acidic deposition is a relatively new phenomenon for Nova Scotia, as claimed. If so, this means that Nova Scotia, to the best of my knowledge, had a much greater percentage of $\mathrm{pH}<5.0$ lakes in the absence of acidic deposition, $-43 \%$ (Gorham, 1957), than reported for areas of North America currently receiving high rates of acidic deposition. Similarly, the Canadian national acid rain lake survey reports that $47.3 \%$ of surveyed Nova Scotia lakes are $\mathrm{pH}<4.7$ which is again, to the best of my knowledge, a percentage of highly acidic lakes 
greater than any reported for areas of North America receiving high rates of acidic deposition (Kanciruk et al., 1986). All of these date suggest that natural acidity may be important for Nova Scotian surface waters.

Kessel-Taylor (1986) hypothesizes that multiple factors are responsible for fisheries problems in Nova Scotia, as many are doing for the Adirondacks (e.g., Pfeiffer and Festa, 1980; Retzsch et al., 1982; Baker and Harvey, 1984; Malanchuk and Turner, 1987). In addition to the possible influence of acidic deposition on fisheries, Kessel-Taylor (1986) cites other factors such as: numerous dams built on rivers, destruction of spawning habitat by severe erosion and by floating of logs down rivers, and poor fishing practicessuch as the practice of stretching large nets across the mouths of rivers to catch salmon (Kessel-Taylor, 1986).

Kessel-Taylor (1986) also notes that after 1960 commercial fishermen located areas off Newfoundland and Greenland where populations of Atlantic salmon would school. Commercial fishing of salmon in the ocean was reported to have had a profoundly negative influence on river salmon fishing in the Maritime Provinces (Kessel-Taylor, 1986).

In the late 1960's, my personal experience of the influence of Atlantic netting of salmon on salmon catch in Scotland paralleled that reported by Kessel-Taylor (1986) for the Atlantic Provinces of Canada. Commercial salmon fishing in the Atlantic ocean was credited with drastic reductions in salmon runs in Scotland. Local BBC broadcasts stated that daily counts of salmon running up fish ladders were, in some instances, reduced from 8,000 per day in 1967 to 8 per day in 1968 because of netting of Scottish salmon populations off Greenland (Krug, personal observation).

Kessel-Taylor (1986) also notes that natural acidity of rivers can also be

$$
3-28
$$


a factor influencing salmon populations. Acidic rivers in Nova Scotia have extensive areas of peaty wetlands in their watersheds while the watersheds of non-acidic rivers had little wetland and much deep, well drained mineral soil. She reasoned that waters draining from such wetlands are naturally acidic, as is also apparent from the river-water data of Thompson (1986) in Table 1.

Kessel-Taylor (1986) further suggests that human influence on water acidity is not just limited to acid rain but also includes watershed activities that enhance the transfer of natural acidity into receiving waters. For example, the recent practice of draining peatlands to mine peat as fuel was hypothesized as enhancing oxidation of reduced sulfur to $\mathrm{H}_{2} \mathrm{SO}_{4}$ and, thereby, increasing acidity of drainage water (Kessel-Taylor, 1986). She also claims that Rosenqvist's changing land-use hypothesis is very relevant for Nova Scotia. Much of Nova Scotia is recovering from widespread and highly destructive land-use practices, particularly catastrophic fires and cutting. Such practices no longer occur on this large scale. Recovery from such abusive land-use practices means that the landscape itself becomes more acidic which, in turn, may be reflected in increasing water acidity (Kessel-Taylor, 1986). The changing land-use hypothesis for Nova Scotia will be examined in Chapter 3.6.

In sumary, studies cited as proving that acidic deposition is solely responsible for acidification and loss of fish populations do not pass critical examination. Documented declines in freshwater fisheries may be related to multiple factors which can include acidic deposition. 
3.3 The Distribution of Acid-Stressed and Absent Fish Populations in Relation to the Distribution of Acidic Deposition

The distribution of troutless and acid-stressed trout populations for 2,000 lakes in southern Norway have been mapped (Figure 6). This distribution was reported to be "clearly similar to the pattern of presentday acidity of precipitation" (Wright, 1977) and similar to the present day spatial distribution of concentration of $\mathrm{SO}_{4}{ }^{2-}$ in precipitation (Braekke, 1976; Figure 4). Accordingly, deposition of $\mathrm{H}_{2} \mathrm{SO}_{4}$ is considered responsible for these fisheries problems (Braekke, 1976; Wright, 1977; Overrein et al., 1980) or:

"if not, then whatever environmental change has caused acidification of lakes must have a regional pattern of intensity similar to that for the $\mathrm{pH}$ of precipitation" (Wright, 1977).

An immediate problem with the above statement is the assertion that acidification of these Norwegian lakes has occurred. The acceptance of an assumption as fact can not be considered as an alternative to scientific proof. We do not know as fact, that acidification has occurred. All we know from this study is that there are reported to be acidity-related

fisheries problems in southern Norway. We do not know that there has been a change in the acidity of these lakes.

A second problem is the use of correlation to establish causality. Correlation does not establish cause-and-effect (Simon, 1954).

A third problem is that the distribution of troutless and acid-stressed trout populations in southern Norway is not clearly similar to the presentday distribution of acidic deposition. Despite assertions to the contrary (Braekke, 1976; Wright, 1977; Overrein et al., 1980), the 


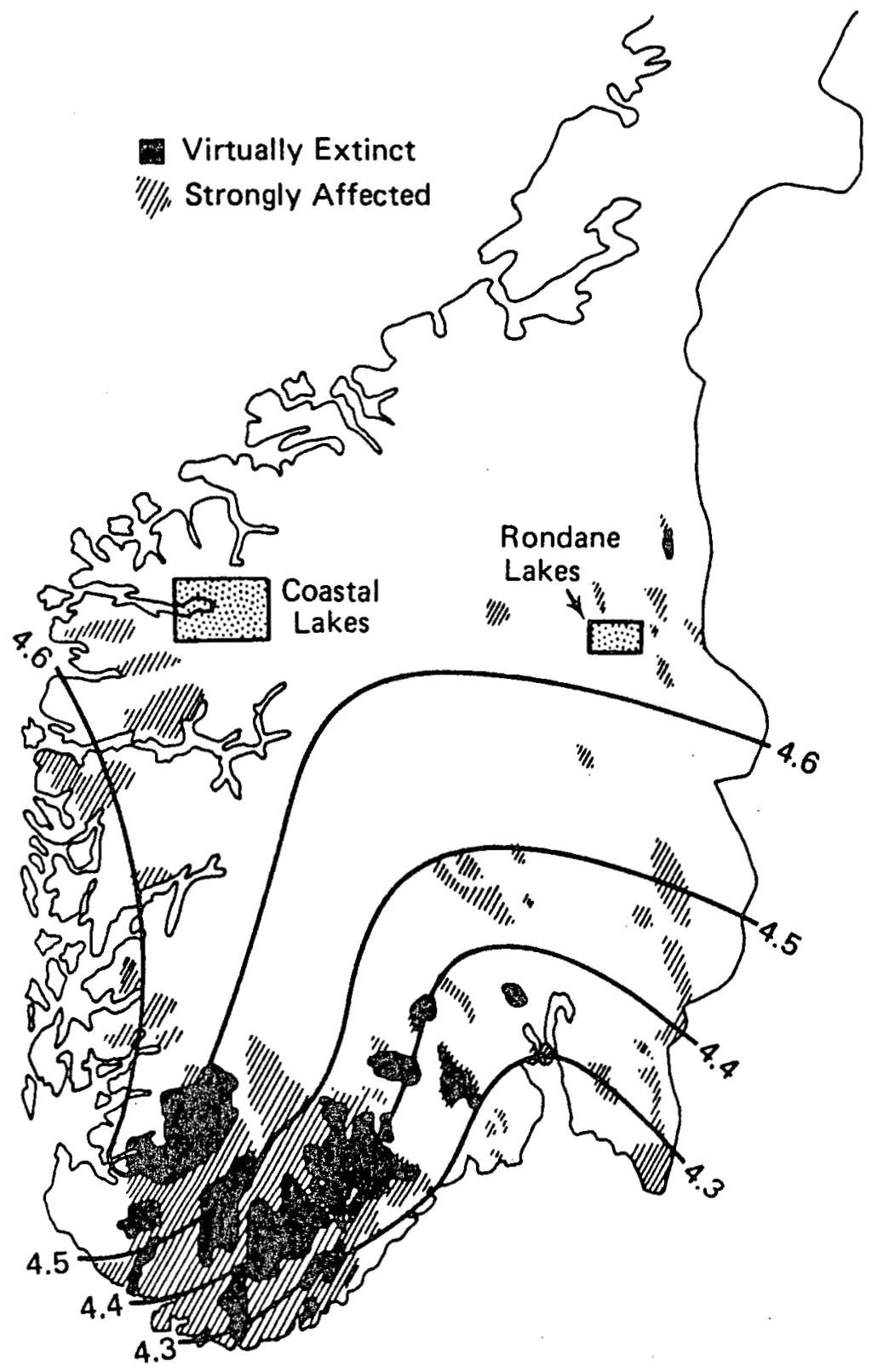

Figure 6. Status of fish populations in lakes of southern Norway in relationship to the distribution of mean annual precipitation $\mathrm{pH}$ and locations of some reportedly acidified lakes. Status of fish populations was based on interviews with local fisheries boards and landowners (Wright, 1977). Distribution of mean annual precipitation $\mathrm{pH}$ and locations of some reportedly acidified lakes are modified from Braekke (1976) and Wright (1977). 
reportedly-affected areas (Figure 6) appear to be not well correlated with precipitation $\mathrm{H}^{+}$and $\mathrm{SO}_{4}{ }^{2-}$ concentration gradients (Figure $4 ; 6$ ). The reportedly-affected areas also exist outside of the acidic deposition (pH less than 4.6) region (Figure 6).

In conclusion, it has not been shown that there is either a strong temporal or spatial correlation of acidic deposition and fisheries problems in southern Norwegian lakes. Nevertheless, such a correlation between acidic deposition and lake acidification has been reported to exist and to prove that acidic deposition is responsible for acidification of Norwegian lakes (Braekke, 1976; Wright, 1977; Overrein et al., 1980).

For some time there has been evidence for an alternative explanation of acid-related fisheries problems in southern Norway:

"For a considerable time trout and salmon hatcheries in southwest Norway found themselves confronted with grave difficulties in rearing." "Many of these hatcheries have actually had to be given up." Furthermore, "It is also well known that a number of apparently fine forest brooks in this region . . are and always have been entirely devoid of trout" (Dahl, 1927).

As seen in Figure 6, the southwest area of Norway described by Dahl (1927) (the area with troutless lakes and acid-stressed trout populations) is asserted to correspond to the current spatial distribution of acidic deposition (Braekke, 1976; Wright, 1977; Overrein et al., 1980).

Dahl (1927) presented data that unequivocally related the fisheries problems of trout and salmon to acidity of water. Moreover, Dahl related acid water to acid soils, "We know the soil of this granite district is very acid." He recommended studying the relationship of acidic water to acidic soil and hydrology (Dahl, 1927).

Dahl's (1927) paper is cited in the "interim report" of the SNSF-Project (Braekke, 1976) but only to the effect that the dilute waters of southwestern 
Norway are highly susceptible to acidification (Braekke, 1976). There is no mention of any possibility of an alternative explanation of acid-related fisheries problem (Braekke, 1976). The SNSF-Project at this time (Braekke, 1976) did not test the alternative hypothesis that runoff from highly acidic soil materials in the absence of acidic deposition may result in highly acidic runoff (Braekke, 1976).

It appears that the distribution of acidity-related fisheries problems cooccurs with the distribution of naturally, highly acidic podzols, peats and thin lithic soil associations (Lag, 1979) and acidity-related fisheries problems pre-date the reported onset of acidic deposition to the area (Dahl, 1927; Braekke, 1976; Rosenqvist, 1978; 1980). The soils of the acidic surface water areas of southern Norway are among the most acidic in the world (Brady, 1974; Oden, 1976; Bergseth, 1977). Because of the predominance of these thin, highly acidic soils (Oden, 1976; Bergseth, 1977; Lag, 1979), if near-surface runoff from highly acidic soils naturally results in pH less than 5.5 runoff, then southwestern Norway is an area that is expected to naturally have pH less than 5.5 surface waters.

In conclusion, acidity-related fisheries problems of southern Norway (Braekke, 1976) are not uniquely spatially and temporally related to the reported advent of acidic deposition (Braekke, 1976). 


\subsection{The Co-occurrence of Natural Soil Acidity with the Distribution of Acidic Deposition}

There is a general north/south soil acidity gradient in Scandinavia. The soils of southermmost Scandinavia are exceedingly acidic, with the mean pH of surface organic horizons being more acidic than 3.4 in southernmost Scandanavia (Oden, 1976). Oden (1976) attributed this north/south soil acidity gradient and the great acidity of southern Scandinavian soils to acidic deposition.

However, it is difficult to see how acidic deposition could lower soil pH to such an extent. Soil $\mathrm{pH}$ is reported to be about $1 \mathrm{pH}$ unit, or 10 times more acidic than the $\mathrm{pH}$ measure of acidity in precipitation (Oden, 1976). This is especially difficult to comprehend given the understanding that oden (1976) and others (Braekke, 1976; Likens et al., 1979; Overrein et al., 1980; National Research Council, 1981; Johnson et al., 1984) have that acidic deposition is a 1960's phenomenon for southern Scandanavia. Thus, about 10 years of precipitation is said to have acidified soil $\mathrm{pH}$ to about 10 times more acidic than the most acidic mean precipitation $\mathrm{pH}$.

The reason why it is untenable to attribute Norwegian soil acidity to acidic deposition is because soils are buffered systems. The acid required to lower $\mathrm{pH}$ of soil materials, especially soil organic horizons, are 1,000's of times its pH measure of acidity (Brady, 1974). The acid content of soils typical of southerm Scandanavia are well known to be equivalent to 1,000's of years of high rates of acidic deposition (Bergseth, 1977; Rosenqvist, 1978; 1980; Krug and Frink, 1983a,b) .

Thus 1,000's of years of high rates of acidic deposition ( $\mathrm{pH} 4.3$ at $1 \mathrm{~m} / \mathrm{yr}$ ) are required to develop levels of soil acidity that oden (1976) attributes to 
acidic deposition. Of course, all of this accumulated acidity would have to be perfectly preserved in the soil. There could be no losses of acidity to mineral weathering over thousands of years. No acidity could leak out of soils to get into surface water. There could be no soil erosion.

The conditions necessary to attribute the highly acidic soils of southern Scandanavia to acidic deposition are extremely unlikely to have occurred. The general north/south soil acidity gradient of Scandanavia appears to be principally a climatically driven natural gradient typical of humid temperate climates grading into polar climates throughout the world (Glinka, 1927; Joffe, 1949; Harries, 1965; Bridges, 1970; Moore, 1976). 


\section{5 current Surface-Water Chemistry}

As discussed in Chapter 3.1, historical water-chemistry data are limited both in quantity and quality. Accordingly, most data reported as showing acidification of surface waters are not based on direct observation of acidification, but are estimates derived from application of chemical principles to current water chemistry data. In order to critically assess the credibility of this vast majority of reports of surface-water acidification, it is important to understand the principles of acidification theory and how they have been applied.

That mineral bases are currently charge balanced to some degree by nonmarine $\mathrm{SO}_{4}{ }^{2-}$ is commonly defined as meaning that $\mathrm{HCO}_{3}-$ alkalinity is replaced by $\mathrm{H}_{2} \mathrm{SO}_{4}$ from atmospheric deposition (Almer et al., 1974; Braekke, 1976; Wright and Gjessing, 1976; Wright et al., 1977; Seip and Tollan, 1978; Henriksen 1979; 1980; Overrein et al., 1980; NAPAP, 1984; 1986; 1987a; 1988; U.S. EPA, 1984; Sullivan et al., 1988).

Figure 7 provides an example of the estimation of surface-water acidification by acidification theory (loss of $\mathrm{HCO}_{3}^{-}$alkalinity by $\mathrm{H}_{2} \mathrm{SO}_{4}$ titration) using contemporary water chemistry data. It is comonly considered that there are three major anions" in "sensitive" surface waters: $\mathrm{HCO}_{3}{ }^{-}, \mathrm{SO}_{4}{ }^{2-}$, and chloride $\left(\mathrm{Cl}^{-}\right)$(Figure 7a). $\mathrm{All} \mathrm{\textrm {Cl } ^ { - }}$ and the portion of $\mathrm{SO}_{4}{ }^{2-}$ that is defined as being marine $\mathrm{SO}_{4}{ }^{2-}$ (on the basis of the $\mathrm{Cl} / \mathrm{SO}_{4}$ ratio of seawater) are assumed to come from seawater. Similarly, other chemical constituents (especially the cations $\mathrm{Na}^{+}, \mathrm{Mg}^{2+}$ ) are usually subtracted out

1. Concentrations of $\mathrm{NO}_{3}^{-}$have been shown to be negligible for most waters of concern, therefore, $\mathrm{NO}_{3}{ }^{-}$is not considered to be a major anion in many acidification studies. 


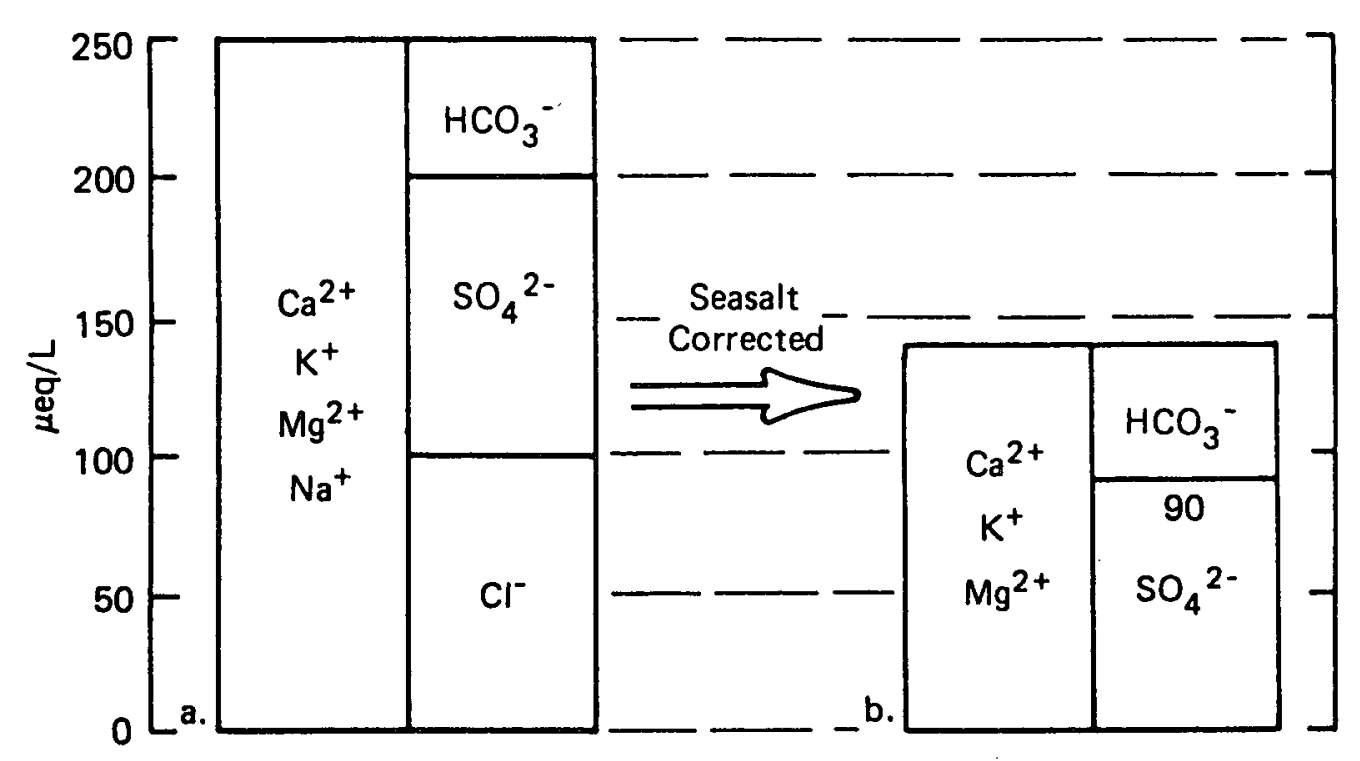

Figure 7. An example of estimation of surface-water acidification by $\mathrm{H}_{2} \mathrm{SO}_{4}$ deposition using typical contemporary water-chemistry data for "sensitive" coastal freshwaters of Scandinavia and eastern North America. Units are ueg/L. Assumptions are:

1. Waters are inorganic solutions where electroneutrality is achieved;

2. Waters were originally bicarbonate $\left(\mathrm{HCO}_{3}^{-}\right)$solutions of mineral base cations $\left(\mathrm{Ca}^{2+}, \mathrm{Mg}^{2+}, \mathrm{K}^{+}, \mathrm{Na}^{+}\right)$;

3. Chloride $\left(\mathrm{Cl}^{-}\right)$represents marine salt contribution. Inputs of neutral salts are considered irrelevant to the issue of acidification. Therefore, inorganic constituents are subtracted out in their proportion to $\mathrm{Cl}^{-}$in seawater, and;

4. Sulfuric acid $\left(\mathrm{H}_{2} \mathrm{SO}_{4}\right)$ deposition/watershed interaction is limited to loss of alkalinity, e.g., increase in rate of mineral weathering and other changes induced by acidic deposition are assumed not to happen.

These limiting assumptions as used in a simple version of the Henriksen $(1979$; 1908) titration model necessitate that non-marine $\mathrm{SO}_{4}{ }^{2-}$ equal acidification (loss of alkalinity). 
from overall water chemical composition in proportion to the composition of seawater (Figure 7b) before any further analysis is conducted.

Seasalt is a neutral salt that is conceptually defined as being incapable of acidifying surface waters on a sustained basis and is, therefore, considered to be merely a confounding factor that is subtracted out of overall water chemical composition (Overrein et al., 1980; Seip, 1980; U.S.EPA, 1984; Reuss et al., 1987).

Subtracting out the chemicals in seasalt leaves behind only $\mathrm{HCO}_{3}^{-}$and nonmarine $\mathrm{SO}_{4}{ }^{2-}$ as major negative ions (anions). The amount that current concentration of SO42- is greater than estimated background concentrations is, by definition, the estimated loss of alkalinity, or acidification by acidic $\mathrm{H}_{2} \mathrm{SO}_{4}$ deposition.

Henriksen (1979) developed a means of estimating background concentrations of $\mathrm{SO}_{4}{ }^{2-}$ in surface waters. He estimated that virtually all non-marine $\mathrm{SO}_{4}{ }^{2-}$ in southern Norwegian lakes is derived from atmospheric deposition. This appears to be the foundation of the current belief that nearly all non-marine $\mathrm{SO}_{4}{ }^{2-}$ in "sensitive" watersheds is derived from atmospheric deposition. This same "proof" of Henriksen's (1979) was also claimed to have proven that acidic $\mathrm{H}_{2} \mathrm{SO}_{4}$ deposition is responsible for acidification (loss of alkalinity) of "sensitive" waters and is the foundation of the theory of surface-water acidification (Figure $7 \mathrm{~b}$ ) .

Henriksen's (1979) "proof" that essentially all non-marine $\mathrm{sO}_{4}{ }^{2-}$ is derived from atmospheric $\mathrm{H}_{2} \mathrm{SO}_{4}$ deposition assumes that estimated loss of alkalinity equals non-marine $\mathrm{SO}_{4}{ }^{2-}$. Thus, his plot of non-marine $\mathrm{SO}_{4}{ }^{2-}$ versus estimated loss of alkalinity was actually a plot of non-marine $\mathrm{SO}_{4}{ }^{2-}$ against itself. It is not too surprising that estimated loss of alkalinity 
is near zero when non-marine $\mathrm{SO}_{4}{ }^{2-}$ is essentially zero. Henriksen's (1979) estimate of background $\mathrm{SO}_{4}{ }^{2-}$ is simply the error term of regressing a variable against itself.

This method of estimating background concentrations of $\mathrm{SO}_{4}{ }^{2-}$ (Henriksen, 1979) is scientifically meaningless. Nevertheless, in the context of acidification theory it is of paramount importance. Since acidification is, by definition, directly proportional to the difference between current and estimated background concentrations of $\mathrm{SO}_{4}{ }^{2-}$ (NAPAP, 1988), erroneously low estimates of background $\mathrm{SO}_{4}{ }^{2-}$ necessarily result in erroneously high estimates of acidification by acidic $\mathrm{H}_{2} \mathrm{SO}_{4}$ deposition. For this reason alone, acidification theory tends to overestimate acidification of surface waters by acidic $\mathrm{H}_{2} \mathrm{SO}_{4}$ deposition.

Subsequently, Henriksen (1980) used acidification theory to develop a nomograph from Norwegian lake surveys' data to reconstruct past lake chemistry and to predict future changes in lake chemistry associated with estimated changes in acidic $\mathrm{H}_{2} \mathrm{SO}_{4}$ deposition. He developed regression lines of base cations (non-marine $\mathrm{Ca}+\mathrm{Mg}$ which are assumed to be the surrogate for original alkalinity) versus non-marine $\mathrm{SO}_{4}{ }^{2-}$ (assumed to be a surrogate for atmospheric deposition of $\mathrm{H}_{2} \mathrm{SO}_{4}$ ) for mean $\mathrm{pH} 5.3$ lakes ( $\mathrm{pH} 5.2-5.4$ ) and mean pH 4.7 lakes (pH4.6-4.8) in Figure 8. Henriksen (1980) claimed that his nomograph prove that acidification of Norwegian surface waters are well described by $\mathrm{H}_{2} \mathrm{SO}_{4}$ titration of bicarbonate $\left(\mathrm{HCO}_{3}{ }^{-}\right)$solutions. Thus, Henriksen (1980) claimed to prove that waters more acidic than predicted from consideration of carbonate chemistry alone must be due to acid rain.

However, the predictive nomograph itself (Figure 8) shows that $\mathrm{H}_{2} \mathrm{SO}_{4}$ titration of alkalinity as defined by Henriksen (1980) does not describe the 


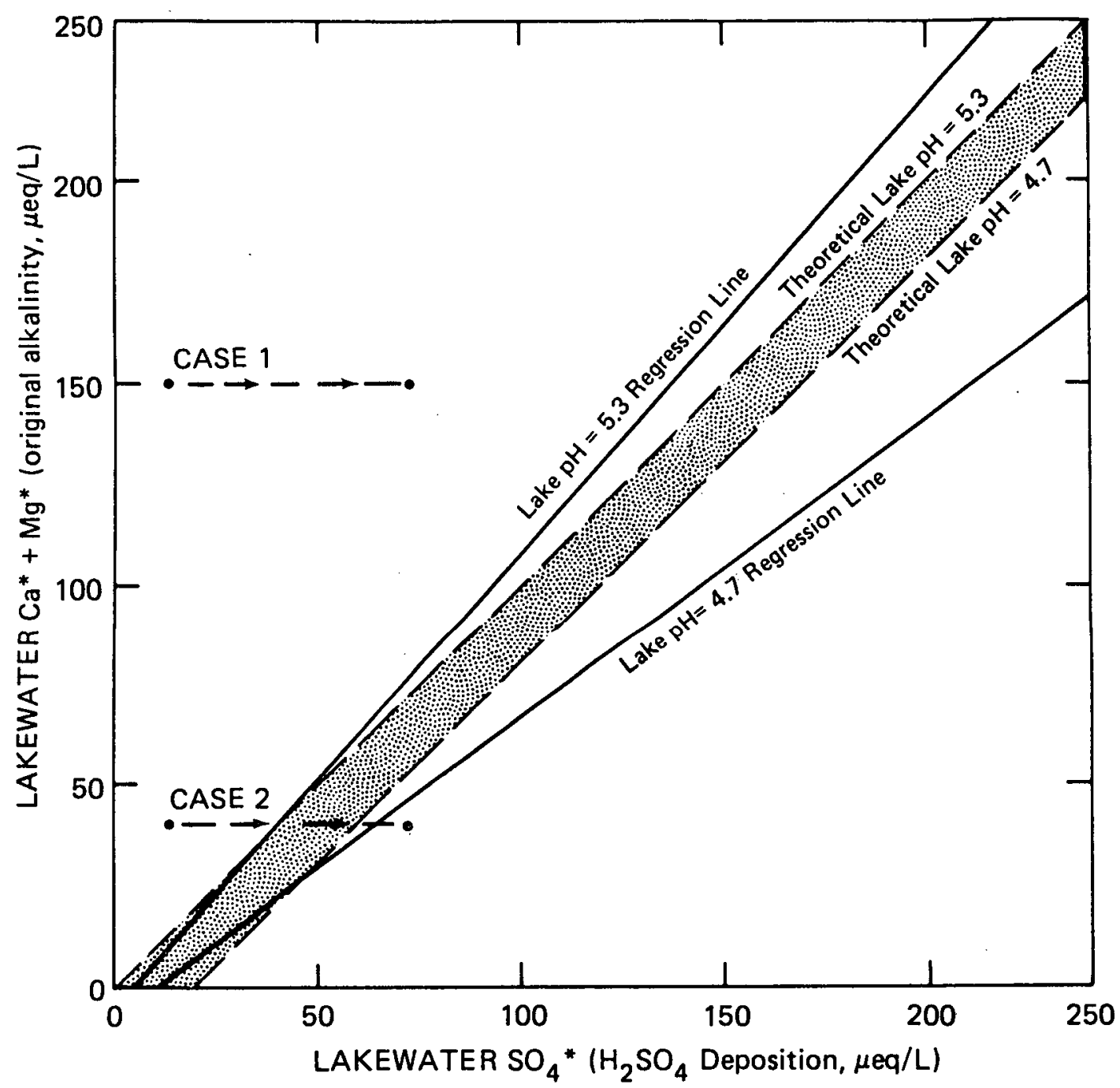

Figure 8. Henriksen predictive nomograph showing pH 5.3-4.7 chemical domains for Norwegian lakes. Theoretical lines described by $\mathrm{H}_{2} \mathrm{SO}_{4}$ titration of $\mathrm{HCO}_{3}^{-}$waters $\left(--{ }_{-}\right)$and actual lines derived from Norwegian lake survey data $(-)$. $*=$ nonmarine. $\mathrm{pH} 5.3$ regression: $\mathrm{Ca} * \mathrm{Mg} *=-5+1.13 \mathrm{SO}_{4} * \mathrm{r}=$ 0.96 . $\mathrm{pH} 4.7$ regression: $\mathrm{Ca} *+\mathrm{Mg} *=-11+0.75 \mathrm{SO}_{4} * \mathrm{r}=0.85$. Modified from Henriksen (1980). 
surface-water chemistry of the lakes used to develop the predictive nomograph. The solution chemistry of $\mathrm{pH} 5.3$ to 4.7 lakes used to develop the nomograph should be described by the narrow chemical domain defined by the $45^{\circ}$ parallelogram shown in Figure 8.

But lakes with $\mathrm{pH}$ 5.3-4.7 lie within the much larger - 4.11 times larger -- cone shaped chemical domain described by Henriksen (Figure 8). In other words, Norwegian lakes with $\mathrm{pH} 5.3$ - 4.7 are 4.1 times more likely to occur than predicted by $\mathrm{H}_{2} \mathrm{SO} 4$ titration of $\mathrm{HCO}_{3}{ }^{-}$solutions. A substantial number of lakes predicted to be less acidic than pH 5.3 are actually more acidic than $\mathrm{pH}$ 5.3. A substantial number of lakes predicted to be more acidic than pH 4.7 are actually less acidic than pH 4.7. Henriksen's (1980) predictive nomograph (Figure 8) shows that the factors controlling the chemistry of Norwegain lakes are more complex than $\mathrm{H}_{2} \mathrm{SO}_{4}$ titration of $\mathrm{HCO}_{3}{ }^{-}$alkalinity.

A simple, straightforward, and unified interpretation of the predictive nomograph (Figure 8) is that Norwegian lakes tend to have some agent that can acidify waters more strongly than predicted by carbonate chemistry while buffering waters against further acidification by acidic $\mathrm{H}_{2} \mathrm{SO}_{4}$ deposition. Thus, this acidifying/buffering agent is necessarily a weak acid which buffers against strong acids in the $\mathrm{pH}$ 5.3-4.7 range and can acidify surface waters more strongly than carbonic acid $\left(\mathrm{H}_{2} \mathrm{CO}_{3}\right)$. The only possible agency that can fit all of these criteria are weak organic. (humic) acids. Ionic aluminum, another possible candidate, does not significantly buffer surface waters above $\mathrm{pH} \sim 5$ (Krug and Frink, 1983a, b) .

Nevertheless, Henriksen (1980) asserted that the nomograph agreed with the principles of titration of $\mathrm{HCO}_{3}^{-}$solutions by $\mathrm{H}_{2} \mathrm{SO}_{4}$ in acidic deposition. Recognizing that the nomograph did not fit the theoretical parallelogram 
described by $\mathrm{H}_{2} \mathrm{SO}_{4}$ titration of $\mathrm{HCO}_{3}^{-}$(Figure 8), Henriksen (1980) still claimed that the nomograph did in fact prove acidification by acid rain because he could modify (or fit) the nomograph to the theoretical parallelogram. Henriksen adjusted the pH 5.3 regression line from a slope of 1.13 to 1.00 by inserting a "correction" factor into the regression equation to account for base cations such as $\mathrm{K}^{+}$that were not accounted for in the original formulation.

Henriksen (1980) said that the lake $\mathrm{pH} 4.7$ regression line had a slope of 0.75 instead of 1.00 because $\mathrm{H}^{+}$from acid rain was dissolving aluminum (Al) from the soils of drainage basins, as well as lowering surface-water pH values. Thus Henriksen claimed that $\mathrm{H}^{+}$as well as ionic $\mathrm{Al}$ are the "acid" cations that represent the acid deposited as $\mathrm{H}_{2} \mathrm{SO}_{4}$. He claimed to prove this point by showing that a $\mathrm{p}(\mathrm{H}+\mathrm{Al})$ regression line has a slope of 1.00 . Assuming that "acid" is represented by both $\mathrm{H}^{+}$and ionic aluminum (Al), Henriksen (1980) fitted the $\mathrm{pH} 4.7$ regression line to the theoretical $\mathrm{pH} 4.7$ line of the parallelogram by using both the concentrations of $\mathrm{H}^{+}$and an estimate of ionic Al by setting $p(H+A l)$ to $4.7^{1}(20 \mathrm{ueq} / \mathrm{L})$.

What Henriksen (1980) actually proved was that Al could not be responsible for the lake pH 4.7 regression line having a slope of 0.75 . Henriksen stated that concentration of $\mathrm{Al}$ is a function of $\mathrm{pH}$. Thus, at $\mathrm{pH}=4.7$, or at any pH below 5.0, a constant fixed amount of ionic aluminum must be in solution. Thus, the $\mathrm{pH} 4.7$ regression line should be parallel to and below the $\mathrm{pH} 5.3$ line by the constant amount of $\mathrm{H}^{+}$and ionic $\mathrm{Al}$ that is in solution at $\mathrm{pH}=$ 4.7. That the adjusted $\mathrm{pH} 4.7$ regression line actually had a slope of 1.00

1. $p$ represents negative logarithm and $p$ of $20 \mathrm{ueq} / \mathrm{L}\left(10^{-6}\right.$ equivalents per liter) is 4.7 . 
and not 1.13 is inconsistent with Henriksen's assumption about constancy of water chemistry used to adjust the $\mathrm{pH} 5.3$ regression line to fit the parallelogram predicted by acidification theory. Thus, Henriksen (1980) also proved that his adjustment of the $\mathrm{pH} 5.3$ regression line to fit the theoretical parallelogram is also not scientifically credible.

Apparently a factor(s) other than the proposed large scale titration by acid rain has a significant influence on the acidity of surface waters in southern Norway. In order to explain this discrepancy, data from the Norwegian lake surveys (Wright et al., 1977; Wright and Snekvik, 1977) used to develop Henriksen's (1980) model will be briefly examined and discussed. They will also be used to examine an alternative hypothesis that natural acidity in the form of humic acids can have an important influence on the acidity of Norwegian lakes (Krug et al., 1985).

Alkalinity was not analyzed as part of the Norwegian lakes surveys (Wright et al., 1977; Wright and Snekvik, 1977):

"because of the insensitivity of the method at the extremely low concentrations present in most Norwegian lakes and especially acid lakes" (Wright et al., 1977).

That alkalinity was never measured is obviously a serious problem when modeling loss of alkalinity. Present concentrations of alkalinity $\left(\mathrm{HCO}_{3}{ }^{-}\right)$ were assumed to be represented by anion deficit: the shortfall of negative ions (the anions $\mathrm{Cl}^{-}, \mathrm{SO}_{4}{ }^{2-}$, and $\mathrm{NO}_{3}{ }^{-}$) relative to positive ions (the cations $\mathrm{H}^{+}, \mathrm{Ca}^{2+}, \mathrm{Mg}^{2+}, \mathrm{K}^{+}$, and $\left.\mathrm{Na}^{+}\right)$:

$$
\left[\mathrm{HCO}_{3}^{-}\right]=\left[\mathrm{H}^{+}+\mathrm{Ca}^{2+}+\mathrm{Mg}^{2+}+\mathrm{K}^{+}+\mathrm{Na}^{+}\right]-\left[\mathrm{Cl}^{-}+\mathrm{SO}_{4}^{2-}+\mathrm{NO}_{3}^{-}\right] \text {i [ ] is }
$$

Thus, $\mathrm{HCO}_{3}^{-}$present in Norwegian surface waters was determined by difference assuming that surface waters are strictly inorganic solutions (i.e., there are no negative organic anions, $\mathrm{RCOO}^{-}$, to account for in the $3-43$ 
above equation).

Wright et al. (1977) claimed to have proved that anion deficit is a reasonable estimate of $\mathrm{HCO}_{3}^{-}$alkalinity by comparing anion deficit with $\mathrm{HCO}_{3}{ }^{-}$ alkalinity as measured by potentiometric titration to $\mathrm{pH} 4.5$ for some of the surveyed lakes. Potentiometric titration is the use of a pH meter to determine the quantity of acid titrated into a sample of water to reduce its $\mathrm{pH}$ to a certain value: in this case to $\mathrm{pH} 4.5$. It is assumed that the amount of $\mathrm{H}^{+}$added to achieve a $\mathrm{pH}$ of 4.5 represents titration of $\mathrm{HCO}_{3}{ }^{-}$:

$$
\mathrm{H}^{+}+\mathrm{HCO}_{3}^{-}=\mathrm{H}_{2} \mathrm{CO}_{3}=\mathrm{H}_{2} \mathrm{O}+\mathrm{CO}_{2} \text {. }
$$

Thus, addition of $\mathrm{H}^{+}$converts alkalinity $\left(\mathrm{HCO}_{3}{ }^{-}\right)$to $\mathrm{H}_{2} \mathrm{CO}_{3}$ which in turn decomposes to the gas, $\mathrm{CO}_{2}$, and water, $\mathrm{H}_{2} \mathrm{O}$. The correlation between anion deficit and potentiometric titration estimates of $\mathrm{HCO}_{3}^{-}$alkalinity was reported to be near perfect: having a slope of 1.00 ; an intercept of 0 , and; $r=0.96$ (Wright et al., 1977).

However, it is chemically impossible for $\mathrm{pH} 4.5$ potentiometric titration to represent $\mathrm{HCO}_{3}{ }^{-}$alkalinity for such dilute $\mathrm{HCO}_{3}{ }^{-}$waters. The $\mathrm{pH}$ endpoint at which alkalinity is zero $\left(\mathrm{H}^{+}=\mathrm{HCO}_{3}{ }^{-}\right)$depends upon how much $\mathrm{HCO}_{3}{ }^{-}$was present before the titration. For example, exceedingly dilute solutions (such as rain water) the $\mathrm{pH}$ endpoint where alkalinity $=0$ is about $\mathrm{pH}$ 5.6. This is why many scientists have considered the $\mathrm{pH}$ of unpolluted precipitation $\left(\mathrm{CO}_{2}+\mathrm{H}_{2} \mathrm{O}\right)$ to be about $\mathrm{pH}$ 5.6. The standard Methods for the Examination of Water and Wastewater (APHA, 1971) that was in use at the time of these Norwegian lake surveys shows that the $\mathrm{pH} 4.5$ alkalinity endpoint is correct for waters with 10,000 ueq/L original alkalinity; $\mathrm{pH}=4.8$ is correct for waters with 3,000 ueq/L original alkalinity, and; $\mathrm{pH}=5.1$ for waters with 600 ueq/L original alkalinity. 
Table 3 shows that lakes surveyed by Wright et al. (1977) in southern Norway tend to have total ionic concentrations (including seasaits) less than $600 \mathrm{ueq} / \mathrm{L}$. Thus, original (pre-acidification) alkalinity is necessarily less than $600 \mathrm{ueq} / \mathrm{L}$. Accordingly, the error between actual alkalinity and pH 4.5 endpoint titration alkalinity (for $\mathrm{HOO}_{3}^{-}$solutions) approximates the difference in $\mathrm{H}^{+}$concentration between $\mathrm{pH} 4.5$ and the actual $\mathrm{pH}$ at which alkalinity $=0$ (Kramer and Tessier, 1982). In this case, the error is the difference in $\mathrm{H}^{+}$between $\mathrm{pH} 4.5$ and $\mathrm{pH} \sim 5.1$, i.e. error $\sim 24$ ueq/L.

Henriksen, a co-author of Wright et al. (1977), later stated that the error between actual alkalinity and $\mathrm{pH} 4.5$ titration endpoint measure of alkalinity is $32 \mathrm{ueg} / \mathrm{L}$ (Henriksen, 1979). A value of $32 \mathrm{ueg} / \mathrm{L}$ is the difference in concentration of $\mathrm{H}^{+}$between $\mathrm{pH} 7.0$ and 4.5. Henriksen's (1979) alkalinity correction value was not correct. In a subsequent 1980 publication, Henriksen (1980) stated that the pH 4.5 titration endpoint measure of alkalinity is accurate for the surveyed southern Norwegian lakes, referencing his 1979 publication (Henriksen, 1979) in support of this statement when that publication said that there was an error with the pH 4.5 endpoint alkalinity method (Henriksen, 1980).

The error of approximately $24 \mathrm{ueq} / \mathrm{L}$ in estimated alkalinity for surveyed Norwegian lakes is significant. This error approximates or exceeds the anion deficit for 3 of the 4 southern Norwegian lake populations (Table 3). In the one lake group with mean $\mathrm{pH}$ below 5.0 (mean $\mathrm{pH}=4.76 ; \mathrm{H}+=17.3$ ueq $/ \mathrm{L}$ ), mean anion deficit of $15.9 \mathrm{ueg} / \mathrm{L}$ (Table 3). As discussed, $\mathrm{HCO}_{3}{ }^{-}$in association with the products of mineral weathering $\left(\mathrm{Ca}^{2+}, \mathrm{Mg}^{2+}, \mathrm{K}^{+}\right.$, and $\left.\mathrm{Na}^{+}\right)$does not exist for waters of these ionic concentrations at such acidic pH values. Assuming that the chemical analyses are correct, this necessarily leaves us 
Table 3. Mean Chemical Values of Geographic/Chemical Lake Groups Obtained by a Cluster Analysis of the 1974 Survey of Small Headwater Lakes in Southern Norway by Wright et al. (1977).

\begin{tabular}{|c|c|c|c|c|c|}
\hline \multicolumn{2}{|c|}{ Parameter } & \multirow{2}{*}{$\begin{array}{l}\text { South-Centralt } \\
\text { Central Group } \\
(52 \text { Lakes })\end{array}$} & \multirow{2}{*}{$\begin{array}{c}\begin{array}{c}\text { Coastal Group } \\
(20 \text { Lakes })\end{array} \\
5.40\end{array}$} & \multirow{2}{*}{$\begin{array}{c}\begin{array}{c}\text { Eastern Group } \\
(26 \text { Lakes })\end{array} \\
4.76\end{array}$} & \multirow{2}{*}{$\begin{array}{r}\begin{array}{r}\text { Western Group } \\
(23 \text { Lakes })\end{array} \\
5.22\end{array}$} \\
\hline$\overline{\mathrm{pH}}$ & & & & & \\
\hline $\mathrm{H}$ & ueq/L & 0.3 & 3.9 & 17.3 & 6.0 \\
\hline $\mathrm{Na}$ & ueq/L & 32.2 & 132.6 & 67.8 & 48.3 \\
\hline $\mathrm{K}$ & ueq/L & 6.1 & 5.6 & 5.4 & 3.3 \\
\hline $\mathrm{Ca}$ & ueq/L & 138.7 & 52.9 & 56.4 & 18.0 \\
\hline $\mathrm{Mg}$ & ueq/L & 36.2 & 41.1 & 38.7 & 16.5 \\
\hline $\mathrm{Al}$ & $\mathrm{uq} / \mathrm{L}$ & 28 & 86 & 208 & 55 \\
\hline $\mathrm{NO}_{3}$ & ueq/L & 2.2 & 2.8 & 1.0 & 1.2 \\
\hline $\mathrm{SO}_{4}$ & ueq/L & 65.4 & 68.8 & 98.7 & 33.1 \\
\hline $\mathrm{Cl}$ & ueq/L & 21.4 & 129.7 & 70.0 & 46.0 \\
\hline$\Sigma M$ & ueq/L & 213.5 & 236.1 & 185.6 & 92.1 \\
\hline$\Sigma \mathrm{A}$ & ueq/L & $\underline{89.0}$ & 201.3 & 169.7 & 80.3 \\
\hline$\overline{\Sigma M}-\Sigma A$ & ueq/L & 124.5 & 34.8 & 15.9 & 11.8 \\
\hline
\end{tabular}

Modified from Braekke (1976). $\quad \Sigma M=\Sigma\left(\mathrm{H}^{+}+\mathrm{Ca}^{2}++\mathrm{Mg}^{2+}+\mathrm{K}^{+}+\mathrm{Na}^{+}\right)$. $\Sigma A=\Sigma\left(\mathrm{NO}_{3}^{-}+\mathrm{SO}_{4}{ }^{2-}+\mathrm{Cl}^{-}\right) . \quad \Sigma \mathrm{M}-\Sigma \mathrm{A}=$ anion deficit. 
with humate $\left(\mathrm{RCOO}^{-}\right)$, the conjugate base of humic acids $\left(\mathrm{RCOOH}=\mathrm{H}^{+}+\mathrm{RCOO}^{-}\right)$, which can exist at such acidic $\mathrm{pH}$ values, for $\mathrm{pH}$ less than 5.1:

$$
\left[\mathrm{RCOO}^{-}\right]=\left[\mathrm{H}^{+}+\mathrm{Ca}^{2+}+\mathrm{Mg}^{2+}+\mathrm{K}^{+}+\mathrm{Na}^{+}\right]-\left[\mathrm{Cl}^{-}+\mathrm{SO}_{4}^{2-}+\mathrm{NO}_{3}^{-}\right] \text {; i [ ] is }
$$

Humic acids ( $\mathrm{RCOOH}$ ) are weak acids that acidify waters to $\mathrm{pH}$ values more acidic than possible by carbonic acid $\left(\mathrm{H}_{2} \mathrm{CO}_{3}\right)$. But, like all weak acids, humic acids buffer against acidification by strong acids, such as $\mathrm{H}_{2} \mathrm{SO}_{4}$ and $\mathrm{HNO}_{3}$. A brief discussion of acid/base concepts is contained in a footnote ${ }^{1}$. Thus humic acids are a fundamental unifying factor that can explain the nonideal behaviors of both the $\mathrm{pH} 5.3$ and 4.7 regression lines in Henriksen's nomograph (Figure 8; Henriksen, 1980). For the pH 5.3 line, Norwegian lakes are more acidic than predicted for $\mathrm{H}_{2} \mathrm{SO}_{4}$ titration of $\mathrm{HCO}_{3}{ }^{-}$, which indicates the presence of yet another acid. For the pH 4.7 line, which should be controlled by the strong acid, $\mathrm{H}_{2} \mathrm{SO}_{4}$, because there is not any $\mathrm{HCO}_{3}{ }^{-}$with which to buffer the acidic pH 4.7 water, we see that there is an agent

1.) - Strong acids are acids that are 100\% dissociated under environmental conditions of concern ( $\mathrm{pH} 3$ and greater). Such acids are $\mathrm{H}_{2} \mathrm{SO}_{4}$ and $\mathrm{HNO}_{3}$. Weak acids are those acids that do not fully dissociate under environmental conditions of concern. Such acids are $\mathrm{RCOOH}$ and $\mathrm{H}_{2} \mathrm{CO}_{3}$. Because such compounds are not fully dissociated, they can act buffers to resist change in pH due to the addition of "acids" or "bases".

The terms acids and bases are relative terms. Under one set of conditions $\mathrm{H}_{2} \mathrm{CO}_{3}$ is an acid. Under another set of conditions it is defined as a base. Pure water dissociates to give enough $\left[\mathrm{H}^{+}\right]$to equal $10^{-7}$ moles/L which is $\mathrm{pH}$ $=7.0$. Substances that can make water more acidic than $\mathrm{pH} 7.0$ are defined by aqueous chemists as bases, substances that give water $\mathrm{pH}$ values higher than 7.0 are called bases. Relative to pure water, $\mathrm{H}_{2} \mathrm{OO}_{3}$ is an acid because at atmospheric concentrations of $\mathrm{CO}_{2}$ it imparts a pH of 5.6 to water which is more acidic than water itself at $\mathrm{pH}=7.0: \mathrm{H}_{2} \mathrm{CO}_{3}=\mathrm{H}^{+}+\mathrm{HCO}_{3}^{-} ;\left[\mathrm{H}^{+}\right]=10^{-5.6}$ moles $/ \mathrm{L}=\mathrm{pH}$ 5.6. But relative to $\mathrm{pH} 4.0$ acid $\mathrm{H}_{2} \mathrm{SO}_{4}$ rain, $[\mathrm{H+}]=10^{-4.0}$ moles/L, carbonic acid is a base that consumes $\mathrm{H}^{+}$and buffers against decrease in $\mathrm{pH}: \mathrm{H}^{+}+\mathrm{HCO}_{3}{ }^{-}=\mathrm{H}_{2} \mathrm{CO}_{3}=\mathrm{H}_{2} \mathrm{O}+\mathrm{CO}_{2}$.

Similarly, humic acids (collectively designated as RCOOH) can acidify waters to $\mathrm{pH}$ values more acidic than even carbonic acid but relative to strong acids, such as $\mathrm{H}_{2} \mathrm{SO}_{4}$ and $\mathrm{HNO}_{3}$, humic acids act as bases that consume $\mathrm{H}^{+}$and buffer against decrease in $\mathrm{pH}: \mathrm{H}^{+}+\mathrm{RCOO}^{-}=\mathrm{RCOOH}$. 
(albeit another acid) that buffers against acidification by strong acid.

What we see is that the data present a de facto argument for the considerable importance of humic acids in the surveyed Norwegian waters. The titration of $\mathrm{HCO}_{3}$ - alkalinity by $\mathrm{H}_{2} \mathrm{SO}_{4}$ only correlates with $24 \%$ of the lake in Henriksen's predictive nomograph (Henriksen, 1980; Figure 8). Even if this correlation was truly causal, acidic deposition/alkalinity interaction as stated by Henriksen (1980) is not the sole process of acidification, or even the dominant process of acidification of Norwegian lakes. Other watershed processes and interactions, while strongly indicated in the data, are ignored. The single mindedness of the interpretation of lake data has led to the development of an acidification theory that is not even supported by the data from which it was developed.

Returning to the issue of anion deficit for acidic ( $\mathrm{pH}$ less than 5.0) Norwegian waters, two additional points must be made:

1. Present levels of $\mathrm{RCOO}^{-}$(as indicated by anion deficit) should not be considered to represent pre-acid rain levels of humate any more than present levels of $\mathrm{HCO}_{3}{ }^{-}$can be considered to represent pre-acid rain levels of $\mathrm{HCO}_{3}{ }^{-}$. And, as is also the case for $\mathrm{HCO}_{3}{ }^{-}$systems, $\mathrm{RCOO}^{-}$ will buffer water against the addition of strong acids, albeit at $\mathrm{pH}$ values more acidic than possible by $\mathrm{HCO}_{3}{ }^{-}$in surface waters.

2. Present concentrations of $\mathrm{RCOO}^{-}$are seriously underestimated by conventional estimates of anion deficit. Such estimates using base cations and $\mathrm{H}^{+}$are reasonable for $\mathrm{HCO}_{3}^{-}$systems because of their high $\mathrm{pH}$ values. However, for $\mathrm{pH}$ values more acidic than $5.0-5.5$, there are ionic metals in solution (e.g., $\mathrm{Al}^{3+}, \mathrm{AL}(\mathrm{OH})_{n}{ }^{3-\mathrm{n}^{+}}, \mathrm{Fe}^{3+}$, $\left.\mathrm{Fe}(\mathrm{OH}) \mathrm{n}^{3-\mathrm{n}+}, \mathrm{Zn}^{2+}, \mathrm{Mn}^{2+}, \mathrm{Cu}^{2+}, \mathrm{Pb}^{2+}\right)$. $\left[\mathrm{RCOO}^{-}\right]-\left[\mathrm{Al}^{3+}+\mathrm{AL}(\mathrm{OH}) \mathrm{n}^{3-\mathrm{n}^{\prime}+}+\mathrm{Fe}^{3+}+\mathrm{Fe}(\mathrm{OH}) \mathrm{n}^{3-\mathrm{nt}}+\mathrm{Zn}^{2+}+\mathrm{Mn}^{2+}+\right.$ $\left.\mathrm{Cu}^{2+}+\mathrm{Pb}^{2+}\right]=\left[\mathrm{H}^{+}+\mathrm{Ca}^{2+}{ }^{\mathrm{n}}+\mathrm{Mg}^{2+}+\mathrm{K}^{+}+\mathrm{Na}^{+}\right]-\left[\mathrm{Cl}^{-}+\mathrm{SO}_{4}^{2-}+\mathrm{NO}_{3}^{-}\right]$. The existence of ionic metals is a major concern in regard to the potential aquatic effects of acidic deposition. But they do not seem to be well considered in regard to their influence on ion balance. Individually, most of these metals usually exist in minute quantities. But in sum total, their contribution to error in estimation of anion deficit can be considerable, especially for low concentration waters that are of concern regarding acidification. Thus the anion deficit estimate of $\left[\mathrm{RCOO}^{-}\right]$ underestimates $\left[\mathrm{RCOO}^{-}\right]$by cations not considered in the anion

$$
3-48
$$


deficit estimate $e^{e \cdot g \cdot} \cdot \mathrm{Al}^{3+}+\mathrm{AL}(\mathrm{OH}) \mathrm{n}^{3-\mathrm{n}+}+\mathrm{Fe}^{3+}+\mathrm{Fe}(\mathrm{OH}) \mathrm{n}^{3-\mathrm{n}+}+$
$\left.\mathrm{Zn}^{2+}+\mathrm{Mn}^{2+}+\mathrm{Cu}^{2+}+\mathrm{Pb}^{2+}\right]$.

The influence of metals on ion balance for acidic waters is illustrated by published National Surface Water Survey (NSWS) sum of cation and anion data for lakes surveyed in the eastern U.S. during the fall of 1984 (Table 4). Total Al in solution ( $\mathrm{A} \mathrm{l}_{\text {tot }}$ ) is included in Table 4 as a useful surrogate for dissolved metals.

Table 4 shows that for low DOC (less than $2 \mathrm{mg} C / L$ ) NSWS lakes with $\mathrm{pH}$ less than 5.0 lakes there is an anion excess (more negative ions than positive ions) of about $26 \mathrm{ueq} / \mathrm{L}$. Urmeasured metal ions must be greater than $26 \mathrm{ueq} / \mathrm{L}$ because organic anions $(0.86 \mathrm{mg} \mathrm{DOC} / \mathrm{L})$ which contribute to anion concentration are also unmeasured. If mean water $\mathrm{pH}$ is 3.5 and there are no Al-complexing ligands, such as $\mathrm{SO}_{4}{ }^{2-}$ and $\mathrm{F}^{-}$present, then $\mathrm{Al}_{\text {tot }}=\mathrm{Al}^{3+}=20.3$ ueq/L. In dilute solutions, essentially all dissolved aluminum is $\mathrm{Al}^{3+}$ at $\mathrm{pH}$ $=3.5$, at mean $\mathrm{pH} 4.62$ (Table 4) the net charge of dissolved aluminum is less than ${ }^{3+}$. Given the presence of $\mathrm{SO}_{4}{ }^{2-}$ and $\mathrm{F}^{-}$which complex with and further reduce the charge per Al ion, ionic Al is considerably less than the value of 20.3 ueg/L assumed for a charge of $3+$ per Al ion for low DOC, pH less than 5.0 lakes of the NSWS (Table 4). Thus anion deficit inherent to ionic aluminum is less than the $20.3 \mathrm{ueg} / \mathrm{L}$ as assumed from $\mathrm{Al}_{\text {tot }}=\mathrm{Al}^{3+}$. Therefore, metals other than Al are in ionic form and also contribute to the significant error in ion balance-based estimates of humate in low DOC, acidic waters.

In summary, for Iow DOC, pH less than 5.0 NSWS lakes, the presence of unaccounted for ionic metals in determining ion balance results in a mean error of at least $26 \mathrm{ueq} / \mathrm{L}$ (Table 4). In waters with appreciable organic acids, this is represented as the error in underestimating the contribution 
Table 4. Some Mean Chemical Parameters of $\mathrm{pH}<5.0$

Southern Norwegian and Eastern United States

Lakes of the National Surface Water Survey (NSWS).

\begin{tabular}{|c|c|c|c|c|c|c|c|c|c|c|}
\hline GROUP & $(n)$ & $\begin{array}{c}A * \\
\text { (ueq/L) }\end{array}$ & $\begin{array}{c}M * * \\
\text { (ueq/L) }\end{array}$ & $\begin{array}{c}(A-M) \\
(\text { ueq/L) }\end{array}$ & $\begin{array}{l}\text { DOC } \\
(\mathrm{mg} / \mathrm{L})\end{array}$ & $\begin{array}{c}\text { ANC } \\
(\text { ueq/L) }\end{array}$ & $\begin{array}{c}\mathrm{pH} / \mathrm{H} \\
(\mathrm{pH} / \text { ueq/L) }\end{array}$ & $\begin{array}{c}\mathrm{Cl} \\
\text { (ueq/L) }\end{array}$ & $\begin{array}{c}\mathrm{SO}_{4} \\
(\mathrm{ueq} / \mathrm{L})\end{array}$ & $\begin{array}{l}\text { A1 tot } \\
(\mathrm{ug} / \mathrm{L})\end{array}$ \\
\hline NSWS DOC $<2 \mathrm{mg} / \mathrm{L}$ & (24) & 290.5 & 264.3 & +26.2 & 0.86 & -27.0 & $4.62 / 24.1$ & 149.8 & 133.2 & 182.8 \\
\hline NSWS DOC $2-6 \mathrm{mg} / \mathrm{L}$ & $(27)$ & 140.3 & 139.3 & +1.0 & 4.09 & -15.9 & $4.70 / 19.8$ & 35.3 & 99.7 & 225.9 \\
\hline NSWS Al1 & (75) & 192.3 & 215.8 & -23.5 & 9.52 & -36.3 & $4.49 / 32.6$ & 97.5 & 78.3 & 183.0 \\
\hline $\begin{array}{l}\text { Norwegian South- } \\
\text { Central +Eastern } \\
\text { Lakes }\end{array}$ & (26) & 169.7 & 185.6 & -15.9 & N.D. & N.D. & $4.76 / 17.3$ & 70.0 & 98.7 & 208 \\
\hline $\begin{array}{l}\text { NSWS Stump Pond, } \\
\text { N.H. (NSWS) }\end{array}$ & (1) & 153.8 & 177.1 & -23.3 & 9.05 & -4.0 & $4.81 / 15.4$ & 29.4 & 96.8 & 211.4 \\
\hline
\end{tabular}

N.D. = not determined.

NSWS data from Kanciruk et al. (1986).

Norwegian data from Braekke (1976) subsequently published by Wright et al. (1977).

$* \mathrm{~A}=\mathrm{SO}_{4}^{2-}+\mathrm{Cl}^{-}+\mathrm{NO}_{3}^{-}$for Norwegian data.

$* \mathrm{~A}=\mathrm{SO}_{4}^{2-}+\mathrm{Cl}^{-}+\mathrm{NO}_{3}^{-}+\mathrm{F}^{*}+\mathrm{HCO}_{3}^{-}$for NSWS data. $\mathrm{F}^{-}$and $\mathrm{HCO}_{3}^{-}$(for $\mathrm{pH}^{-}<5.0$ ) are relatively insigificant in terms of total concentration of anions (A).

$* * * \mathrm{M}=\mathrm{H}^{+}+\mathrm{Ca}^{2+}+\mathrm{Mg}^{2+}+\mathrm{K}^{+}+\mathrm{Na}^{+}$for Norwegian data.

$* * \mathrm{M}=\mathrm{H}^{+}+\mathrm{Ca}^{2+}+\mathrm{Mg}^{2+}+\mathrm{K}^{+}+\mathrm{Na}^{+}+\mathrm{HN}_{4}^{+}$for NSWS data. 
of organic acids to acidity of water. That this error approximates the mean concentration of $\mathrm{H}+$ in these waters (Table 4) indicates that the error is so significant that the source of $\mathrm{H}^{+}$in $\mathrm{pH}$ less than 5.0 NSWS lakes can not be accurately estimated on the basis of anion deficit.

For moderate DOC $(2-6, \mathrm{mg} / \mathrm{L})$, $\mathrm{pH}$ less than 5.0 NSWS waters, mean concentration of $\mathrm{Al}$ tot is $24 \%$ greater than for low DOC waters (Table 4). But mean anion excess is reduced from about $26 \mathrm{ueq} / \mathrm{L}$ to $1 \mathrm{ueg} / \mathrm{L}$ by the extra $3 \mathrm{mg}$ DOC/L (mean concentration) in the moderate DOC waters (Table 4). But, this ion balance indicates the presence of no organic acids while it is estimated that at least $26 \mathrm{ueq} / \mathrm{L}$ are present. The mean concentration of $\mathrm{H}^{+}$for these moderate DOC waters is $19 \mathrm{ueq} / \mathrm{L}$ (Table 4), which is less than the estimated concentration (26 ueq/L) of organic acids. Thus, while the conventional interpretation of ion balance would be interpreted as showing that organic acids were not responsible for $\mathrm{H}^{+}$in these moderate DOC, pH less than 5.0 NSWS waters, in fact, organic acids may be responsible for $\mathrm{H}^{+}$in these waters.

For all pH less than 5.0 NSWS lakes, mean DOC increases to $9.5 \mathrm{mg} / 1$, or by about $5 \mathrm{mg} \mathrm{DOC/L}$. Charge balance changes by $25 \mathrm{ueq} / \mathrm{L}$ to about $-24 \mathrm{ueq} / \mathrm{L}$ for all pH less than 5.0 NSWS lakes (Table 4).

The NSWS, pH less than 5.0 lakes can be used to better understand the nature of the acidity in the pH less than 5.0 Norwegian lakes (Table 4), which as discussed, had neither their alkalinity or DoC values measured (Braekke, 1976; Wright et al., 1977). Of the NSWS lakes, Stump Pond in New Hampshire appears to most chemical resemble the "average" NSWS and southern Norwegian pH less than 5.0 lake (Table 4). Given the relationships of DOC, Altot and ion balance, it appears that, on average, in southern Norwegian 
lakes with $\mathrm{pH}$ less than 5.0, humate may account for 55-60 ueg/L, but that measured anion deficit is only about 16 ueg/L (Table 3; 4). Whereas Wright et al. (1977) considered the pH less than 5.0 lakes in Tables 3 and 4 to have about $16 \mathrm{ueq} / \mathrm{L} \mathrm{HCO}_{3}{ }^{-}$alkalinity, in fact, they have no alkalinity. Thus, the estimated error is equal to estimated alkalinity minus estimated organic acidity, or about $70 \mathrm{ueg} / \mathrm{L}$.

The estimated error may be even greater than $70 \mathrm{ueg} / \mathrm{L}$ because the titration loss of humate $\left(\mathrm{RCOO}^{-}\right.$) by $\mathrm{H}_{2} \mathrm{SO}_{4}$ (weak acid acting as a base to buffer additions of strong acid) has not been added in. Since the concentration of non-marine $\mathrm{SO}_{4}{ }^{2-}$ for the mean $\mathrm{pH}$ less than 5.0 Norwegian lake group in Tables 3 and 4 accounts for approximately 90 ueg/L, we see that the error in not considering humic acids is large, even if one assumes that all non-marine $\mathrm{SO}_{4}{ }^{2-}$ in southern Norwegian lakes is atmospherically derived.

The possible influence of organic acids on Norwegian water chemistry was ruled out without testing or measuring for their influence. Similarly, the stated influence of acidic $\mathrm{H}_{2} \mathrm{SO}_{4}$ on loss of alkalinity was made without measuring alkalinity.

Norwegian survey lakes (Wright et al., 1977; Wright and Snekvik, 1977) are widely reported as showing widespread acidification of clearwater lakes of high transparency (Krug et al., 1985). Unfortunately, as discussed, DOC (which is an often-used surrogate for organic acids) was never measured (Wright et al., 1977; Wright and Snekvik, 1977). However, apparent water color of lake water was reported for most headwater lakes surveyed in 1974 by Wright et al. (1977). These data show that there are no pH less than 5.0 clearwaters of high transparency (blue waters in Table 5). Most pH less than 5.0 waters are humic colored (yellow-green through dark brown, Table 5). 
Table 5. Numbers of Small, Headwater, Southern Norwegian Lakes

Surveyed in 1974 by Visual Color and $\mathrm{pH}$.

\begin{tabular}{lccccc}
\hline Lakes & Blue & Green & Yellow-Green & Yellow-Brown & Brown \\
& 10 & 34 & 14 & 32 & 17 \\
Total Number & 0 & 8 & 10 & 15 & 14 \\
Number with $\mathrm{pH}<5.0$ & & & & 3 \\
\hline
\end{tabular}

Data from Wright et al. (1977).

$\omega$
$\omega$
$\omega$ 
Table 5 shows that humic-colored lakes are more likely to be acidic (pH less than 5.0) than not. out of 70 humic-colored lakes, 42 or $60 \%$ of the total are $\mathrm{pH}$ less than 5.0 .

In conclusion, statements that there is widespread acidification of clear,high transparency waters in southern Norway are not well supported by the data from which these statements were derived. However, these water color data, like the Norwegian water chemistry data already discussed (Table 3; 4), also suggest that natural organic acids may significantly influence the chemistry of acidic lakes in Norway.

current levels of organic acids may also be important in explaining the acidity of pH less than 5.0 American NSWS lakes. Kramer and Davies (1988) found that relatively little humic acid, $4 \mathrm{mg} / \mathrm{L}$ reported as DOC, is required to acidify dilute waters typified by pH less than 5 NSWS lakes. Of the 75 lakes with closed $\mathrm{pH}$ values less than 5.0 in the eastern United States reported by the NSWS, 40 have DOC values greater than or equal to $4.0 \mathrm{mg} / \mathrm{L}$ (Kanciruk et al., 1986). It is possible that current concentrations of dissolved humic acids alone would result in $\mathrm{pH}$ values less than 5.0 for over $50 \%$ of the acidic lakes found in the East by the NSWS. Claims that NSWS pH less than 5.0 lakes are acidified principally by atmospheric deposition and that organic acids are unimportant (Linthurst et al., 1986; NAPAP, 1986; 1987a) appear to require more careful consideration.

In conclusion, most data reported as showing acidification are estimates derived by assuming that before the advent of acid rain, surface waters were bicarbonate $\left(\mathrm{HCO}_{3}{ }^{-}\right)$solutions of mineral bases produced by carbonic acid weathering of mineral bases. To the extent and degree that surface waters are different, or more acidic than this hypothetical pristine reference state 
is said to be the extent and degree of acidification by acid rain. Good empirical correlations between water chemical parameters have been reported as proving this now dominant theory of acidification.

Correlative relationships do not establish causal relationships. Assumptions about the original state of the system and assumptions about the nature and extent of acidic deposition/watershed interaction need to be verified. The dominant acidification theory assumes that the only watershed changes are those associated with loss of bicarbonate alkalinity induced by acidic deposition. However, this logically means that all other watershed changes that may have occurred necessarily result in overestimation of acidification by acid rain. This is because default reasoning forces all change to be explained by the single dominant theory, whether such change is real or artificial (the result of incorrect definition of the system).

While correlations are insufficient in themselves to prove an hypothesis, correlations can be sufficient to disprove an hypothesis. Examination of contemporary water chemistry said to prove acidification (loss of alkalinity) by atmospheric deposition of $\mathrm{H}_{2} \mathrm{SO}_{4}$ does not support this now dominant theory of acidification. This theory (under the most generous conditions that force all acidification to one cause) explains only about $24 \%$ of the $\mathrm{pH} 5.3-4.7$ lake water chemistry used to develop this theory. Contrary to the reported scientific consensus, such correlation proves that acid rain is not the sole factor, and probably is not the dominant factor responsible for the high acidity levels of Norwegian lakes.

The failure to adequately consider organic acids and the existence of ionic metals in acidic waters combined with the overestimation of change in concentration of $\mathrm{SO}_{4}{ }^{2-}$ (and, thereby, the overestimation of loss of 
alkalinity) also results in the overestimation of the role of acidic $\mathrm{H}_{2} \mathrm{SO}_{4}$ deposition in the acidification of North American surface waters. An alternative hypothesis of acidification is explored in the next section. 
3.6 Non-steady State Watersheds: Iand-Use Changes and Natural Processes 3.6.1 The Changing Land-Use Hypothesis

Changes other than acidic deposition that increase acidity of water but are ignored necessitate overestimation of surface-water acidification by acidic deposition. Rosenqvist (1978; 1980), and later Krug and Frink (1983a, b), hypothesized that processes of watershed acidification other than acidic deposition have occurred throughout essentially all of eastern North America and northern Europe where acid rain is said to be the sole agent acidifying surface waters to levels more acidic than predicted by acidification theory.

Rosenqvist's (1978; 1980) original changing land-use hypothesis was for acidification of surface waters in southern Norway. He claimed that human activity has profoundly influenced both the terrestrial landscapes and aquatic habitats of southern Norway. He reported that many waters of the region were originally fishless and were subsequently stocked. Long-term, widespread careless and destructive land-use practices resulted in artificially-lowered treelines and, because of erosion, much of the originally forested landscape was converted to rockland barrens and heaths.

In the nineteenth century, a burgeoning population greatly stressed Norway's ability to support itself. This resulted in the exochus to the New World at the same time that major technological and societal changes were occurring in Norway and throughout the western world. As a result, silvicultural and agricultural practices in Norway, Europe, and North America underwent profound transformation around 1850 and onward (Rosenqvist, 1978; 1980; Overrein et al., 1980; Krug and Frink, 1983a, b). 
Recovery from abusive land-use practices in southern Norway started in the latter half of the nineteenth century. This recovery continues in this century. Rosenqvist (1980) documented forest recovery with statistics showing an increase of over $70 \%$ in the volume of standing wood in the southernmost counties of Norway during the period 1927/28 to 1964/73. Changes in land-use practices allowed reversion of previously-used land to forest and heath. It is well known that such change naturally results in more acidic surficial soil horizons and succession to more acidophilic ecosystems, i.e., ecosystems that prefer or require acidic environments. Acidophilic ecosystems work to acidify and maintain environmental acidity (Wherry, 1928; Griffith et al., 1930; Cain, 1931; Heimburger, 1934; Plice, 1934; Young, 1934; Donahue, 1940; Joffe, 1949; Lutz and Chandler, 1946; Tamm, 1950; Clymo, 1963; Viro, 1974; Stone, 1975; Peterson, 1976; Bergseth, 1977; Rosenqvist, 1978; 1980; Overrein et al., 1980; Troedsson, 1980; Nilsson et al., 1982; Duhaime et al., 1983; Gore, 1983; Krug and Frink, 1983a, b; Veneman et al., 1984; Rush et al., 1985; Andrus, 1986; James and Riha, 1986; Kessel-Taylor, 1986).

Rosenqvist (1978; 1980) illustrated the enormous acidification potential of natural soil formation. He showed that, in just 90 years, reforestation of an abandoned farm field resulted in highly acidic and organic-rich surficial soil horizons whose acid content is equivalent to about 1,000 years of $\mathrm{pH} 4.3$ acid rain at $1 \mathrm{~m} / \mathrm{yr}$. This $\mathrm{pH} 4.3$ rate of acid deposition is equivalent to rates of acidic deposition in southermost Norway (Braekke, 1976; Figure 3). Krug and Frink (1983a) estimated that inclusion of acidification of mineral soil underlying the organic rich surficial soil horizons should make soil acidification associated with reforestation of 
Rosenqvist's abandoned farm field equivalent to 2,000 years of acidic deposition in the 90 year period.

Rosenqvist (1978) hypothesized that naturally, highly acidic soil naturally results in highly acidic runoff. Runoff strongly acidified by soil is hypothesized to result in strongly acidic surface waters providing, of course, that runoff does not become subsequently neutralized by passing through underlying mineral soil or geologic materials before entering surface waters. Neither acidic deposition or highly acidic surficial soil material is hypothesized to result in acidic surface waters if it passes through underlying subsoils and permeable bedrock in deep, well drained mineral soil landscapes of recently-glaciated terrain. Thus, Rosenqvist hypothesized that, for surface waters which receive disproportionate amounts of nearsurface runoff, increasing soil acidity results in increasing acidity of surface waters (Rosenqvist, 1978; 1980).

Rosenqvist (1978) used highly acidic surficial soil (humus from the abandoned farm field) in laboratory experiments to demonstrate that the natural process of soil acidification results in strongly acidic runoff in the absence of acidic deposition.

Table 6 shows that this newly developed acidic soil acidified to $\mathrm{pH} \leq 5.0$ the equivalent of 100 years of alkaline ( $\mathrm{pH}=8.0)$ simulated rain applied over a period of only 3 days. Simulated coastal precipitation with its higher neutral seasalt content yielded water more acidic than simulated inland precipitation (Table 6) showing the influence of ionic strength of precipitation on runoff $\mathrm{pH}$, i.e., the more concentrated the solution, the more acidic the runoff from highly acidic soil (Rosenqvist, 1978; 1980). Thus, even under highly unfavorable conditions, highly acidic soils will 
Table 6. Effect of Humus Developed on Abandoned Farmland on $\mathrm{pH}$ of leachate from Simulated Rain.

\begin{tabular}{|c|c|c|c|}
\hline $\begin{array}{l}\text { Treatment } \\
\text { Sum of equivalent } \\
\text { Years of } \\
\text { Precipitation }\end{array}$ & $\begin{array}{l}\text { "Inland Rain" } \\
2.1 \mathrm{mg} / \mathrm{L} \mathrm{NaCl} \\
5.0 \mathrm{mg} / \mathrm{L} \mathrm{Na} \mathrm{Na}_{4} \\
\mathrm{pH} 8.0\end{array}$ & $\begin{array}{c}\text { Sum of equivalent } \\
\text { Years of } \\
\text { Precipitation }\end{array}$ & $\begin{array}{l}\text { "Coastal Rain" } \\
21 \mathrm{mg} / \mathrm{L} \mathrm{NaCl} \\
5.0 \mathrm{mg} / \mathrm{L} \mathrm{Na} \mathrm{Na}_{2} \mathrm{SO}_{4} \\
\mathrm{pH} 8.0\end{array}$ \\
\hline 5 years & $\mathrm{pH} 4.4$ & 5 years & 4.2 \\
\hline 10 years & $\mathrm{pH} 4.6$ & 10 years & 4.3 \\
\hline 15 years & $\mathrm{pH} 4.6$ & 15 years & 4.35 \\
\hline 20 years & $\mathrm{pH} 4.7$ & 20 years & 4.45 \\
\hline 25 years & $\mathrm{pH} 4.7$ & 25 years & 4.5 \\
\hline 30 years & $\mathrm{pH} 4.75$ & 30 years & 4.5 \\
\hline Rest Overnight & & 35 years & 4.6 \\
\hline 35 years & $\mathrm{pH} 4.7$ & 40 years & 4.6 \\
\hline 40 years & $\mathrm{pH} 4.8$ & Rest Overnight & \\
\hline 45 years & $\mathrm{pH} 4.8$ & 45 years & 4.5 \\
\hline 50 years & $\mathrm{pH} 4.8$ & 50 years & 4.6 \\
\hline 55 years & $\mathrm{pH} 4.85$ & 55 years & 4.6 \\
\hline Rest Overnight & & 60 years & 4.65 \\
\hline 60 years & $\mathrm{pH} 4.8$ & 65 years & 4.7 \\
\hline 65 years & $\mathrm{pH} 4.8$ & 70 years & 4.7 \\
\hline 70 years & $\mathrm{pH} 4.9$ & Rest Overnight & \\
\hline 75 years & $\mathrm{pH} \quad 4.9$ & 75 years & 4.65 \\
\hline Rest Overnight & & 80 years & 4.7 \\
\hline 80 years & $\mathrm{pH} 4.9$ & 85 years & 4.7 \\
\hline 85 years & $\mathrm{pH} 4.95$ & 90 years & 4.75 \\
\hline 90 years & $\mathrm{pH} 4.95$ & 95 years & 4.8 \\
\hline 95 years & $\mathrm{pH} 5.0$ & Rest Overnight & \\
\hline 100 years & $\mathrm{pH} 5.0$ & 100 years & 4.75 \\
\hline
\end{tabular}

Modified from Rosenquist (1978). 
strongly acidify water that it contacts. However, under the unusually extreme conditions of Rosenqvist's experiment, the soil was increasingly less able to acidify water with literally a year of $\mathrm{pH} 8$ simulated precipitation being applied in minutes. Such rates of precipitation do not occur in nature.

Rosenqvist (1978; 1980) estimated the relative acidification of runoff by acid rain and acid soil. Using very simple assumptions of ion exchange, he determined that acidic deposition increased the acidity of near-surface runoff from the highly acidic soils characteristic of "sensitive watersheds" in direct proportion to its ability to raise total ionic concentration of water ${ }^{1}$. On this basis, he estimated that acidic deposition could acidify near surface runoff from highly acidic Norwegian soils by about $0.1 \mathrm{pH}$ unit for coastal areas of Norway and about $0.3 \mathrm{pH}$ units for the most inland area of Norway with its lower salt content precipitation (Rosenqvist 1978; 1980). Presumably, by Rosenqvist's hypothesis, even more inland areas such as the Upper Midwest, the Adirondacks, and Ontario could have near-surface runoff acidified more than $0.3 \mathrm{pH}$ units by similar levels of acidic deposition. But, because land-use changes commonly influence soil pH by 1, 2, or more pH units and runoff $\mathrm{pH}$ was correlated to soil pH, Rosenqvist (1978; 1980) concluded that potential acidification of water by acidic deposition is often smaller than what can be induced by land-use change.

To support his hypothesis that $\mathrm{pH}$ of runoff is but poorly controlled by precipitation pH, Rosenqvist (1978; 1980) presented SNSF-Project data

1. This estimate of acidification assumes that there is no alkalinity to buffer against change in pH of runoff from highly acidic soils because the runoff is already strongly acidified. 
showing that storms which produce similar patterns and rates of runoff result in similar $\mathrm{pH}$ values of streamwater regardless of precipitation $\mathrm{pH}$. The example given was one where a storm with a mean $\mathrm{pH}$ of 5.1 resulted in a $\mathrm{pH}$ of 4.4 for a creek during peak flow. Base flow pH was about 5.6. As flow went down, $\mathrm{pH}$ began to recover toward $\mathrm{pH}$ 5.6. But one week later a second storm resulted in a very similar flow and, again, a peak flow pH of 4.4. However, the second storm had a mean $\mathrm{pH}$ value of 4.3. A pH value of 4.3 represents $634 \%$ more free $\mathrm{H}^{+}$than $\mathrm{pH}$ 5.1. Nevertheless, both storms resulted in very similar flows and $\mathrm{pH}$ of runoff.

Rosenqvist (1978; 1980) hypothesized that increased acidity of nearsurface runoff due to changes in acidic deposition is superimposed upon natural processes of soil acidification. He claimed that the effect of landuse change on runoff $\mathrm{pH}$ is often larger than that of acidic deposition.

Rosenqvist's (1978, 1980) hypothesis that acidic soil can naturally result in acidic surface waters that are toxic to aquatic biota agree with the earlier observations and hypothesis of Dahl (1927) discussed in Chapter 3.3 concerning the nature and cause of toxic acidic waters in southwestern Norway before the reported occurrence of acid rain in the region.

Changes in land use appear to be pervasive in areas where it is said that acidic deposition is responsible for surface-water acidification. Many of the extensive heaths of Great Britain, Scandanavia, and the borders of the North Sea are the consequence of earlier and careless land use (Bramryd, 1979). Burning, grazing, and lumbering caused severe erosion that helped to create the unusually thin soils and artificially lowered the treeline in the uplands and low mountains of southern Norway (Overrein et al., 1980). The remaining forests of western Europe all bear the influence of man (Stone, 
1975)

These careless and highly destructive land-use practices were transported to eastern North America with the arrival of Europeans (Defebaugh, 1906; 1907). Extensive review of the literature shows that essentially all land in the northeastern United States has been cut or burned within the last century (Krug and Frink, 1983a, b). The area of the Northeast with the least areal disturbance is New York state. New York was originally essentially completely forested. By the 1920's $99.5 \%$ of its forests were cut and/or burned, most repeatedly so (MacDonald, 1925; Marshall, 1925). It is difficult to conceive that watersheds of lakes sampled in the Northeast by the NSWS were not influenced by human disturbance and land-use change.

Similarly, areas of concern in eastern Canada (Nova Scotia, New Brunswick, southern and central quebec and ontario) had virtually all of their lands cut or burned within the last century (Defebaugh, 1906; 1907). Likewise, it is difficult to conceive of any significant fraction of lakes in these areas of eastern Canada whose watersheds were not influenced by past human disturbance and land-use change.

The forests of northern Europe and eastern North America are recovering from earlier disturbance. The degree of recovery is so great that it is believed to be influencing the global carbon cycle (Bramyrd, 1979; Clawson, 1979; Armentano and Ralston, 1980; Houghton et al., 1983).

There is little doubt that recovery of such disturbed land results in large increases in soil acidity as measured by Rosenqvist (1978; 1980). Indeed, the relationship between soil acidity and vegetation had attracted considerable attention by the 1920's - as indicated by a review of the subject with 750 citations (mostly northern European), of which more than 500 
dealt directly with acidification (Wherry, 1928).

Disturbances such as fire, agriculture, and cutting result in large losses of acidity from highly acidic, organic-rich soils that typify soils of watersheds in areas of concern in eastern North America and northern Europe (Wherry, 1928; Griffith et al., 1930; Cain, 1931; Heimburger, 1934; Plice, 1934; Young, 1934; Donahue, 1940; Joffe, 1949; Lutz and Chandler, 1946; Tarm, 1950; Viro, 1974; Stone, 1975; Peterson, 1976; Bergseth, 1977; Overrein et al., 1980; Troedsson, 1980; Nilsson et al., 1982; Duhaime et al., 1983; Krug and Frink, 1983a,b; Veneman et al., 1984; Rush et al., 1985; James and Riha, 1986; Kessel-Taylor, 1986).

Regarding land-use changes, the Final Report of the SNSF-project reported that:

"More than 50 years ago, Glomme (1928) carried out a large study on the relationship between soil-pH and vegetation in Norway. He wrote that: 'On the whole, there is reason to suppose that the influence of the pH-value on the distribution of plants in nature under humid conditions is less pronounced than the influence of the vegetation on the $\mathrm{pH}$-value and the transformation of the humus layer.' He also showed that burning or clear-cutting in forest areas tends to increase soil-pH. More recent work, e.g. by Bergseth (1977), has confirmed that there is a correlation between vegetation and soil acidity" (Overrein et al., 1980, p.91).

Bergseth (1977) reported that the influence of vegetation on soil water pH is lange, ranging from nearly pH 3 to 7 for different types of vegetation on podzolized soils, which are the principal soil types found in southern Norway (Lag, 1979). Ecological succession on abandoned and disturbed land is one of succession to more acidophilic plant communities and more acidic soils with time (Bergseth, 1977). One of the findings of the SNSF-project regarding changes in land use in southern Norway, was:

"It is quite clear that agriculture and silviculture in Norway have undergone dramatic changes during the last 100-150 years" (Overrein et al., 1980, p.92). 
While soil properties and effects of land-use changes vary between and within sites, some general relationships are evident for "sensitive" watersheds. Land-use and forest management studies in eastern North America and northern Europe (Griffith et al., 1930; Cain, 1931; Lunt; 1932; 1951; Heimburger, 1934; Plice, 1934; Young, 1934; Donahue, 1940; Diebold, 1941; Eaton and Chandler, 1942; Lutz and Chandler, 1946; Tarm, 1950; Ahlgren and Ahlgren, 1960; Viro, 1974; Bergseth, 1977; Troedsson, 1980; Veneman et al., 1984) show the following relationships:

1. The more acidic the soil, the greater the loss of acidity by disturbance and the greater the increase in acidity by recovery;

2. Coniferous forests tend to have more acidic and thicker organic forest floors soil horizons than deciduous forests. Disturbance of coniferous forests tends to have a greater effect on soil acidity than similar disturbance of deciduous forests.

3. Disturbance and recovery of mixed conifer-deciduous forests tends to have an influence on soil acidity intermediate between that of coniferous and deciduous forests. But the effect of disturbance and recovery on soil acidity tends to more resemble that of coniferous forest;

4. Likewise, the more severe the disturbance, e.g., clear-cutting versus selective cutting, the greater the effect of disturbance and recovery on soil acidity. The more intense the burn the more organic acids and plant material are converted to alkaline ash. Therefore, the greater the effect of such disturbance and subsequent recovery on soil acidity;

5. The greater the time of recovery, the greater the acidification, and;

6. Thin, rocky and upland soils tend to be more acidic and organicrich than equivalent downslope soils and soils with thicker mineral subsoils. This soil acidity gradient generally reflects a vegetational gradient with conifers or highly acidophilic heath vegetation occurring on the more acidic peaty and/or upland locations.

In the northeastern United States, some of the most devastating effects of abusive land use has occurred in the spruce-fir forests that occupy acidic peaty locations and the upper slopes of the mountains (Krug and Frink, 
$1983 a, b)$ where acid rain is believed to be responsible for especially severe and widespread acidification of lakes and streams. By the early 1900's essentially all of the spruce-fir forests had been clear-cut as pulpwood. While the original forest was very fire resistant, lumbering was frequently followed by severe fires that largely or completely destroyed the thick, exceedingly acidic (pH less than 4.0) forest floor (Defebaugh, 1907; Heimburger, 1934; Diebold, 1941; Lutz and Chandler, 1946; Krug and Frink, 1983a, b) .

It was because of such damage done to the sensitive landscape of the Adirondack Mountains by cutting, fire, and erosion that the Adirondack Park and Forest Preserve was established (Defebaugh, 1907). Since the early part of this century, the Adirondacks, and similar sensitive mountainous landscapes of the Northeast, are protected from fire (Krug and Frink, 1983b). And cutting, if allowed at all, is severely limited and regulated (Krug and Frink, 1983b). Indeed, fire protection is so efficient that (where determined) the frequency and severity of fires in these forests is even less than that of the pre-settlement era (Krug and Frink, 1983b).

Land-use and forest management studies (Griffith et al., 1930; Cain, 1931; Lunt, 1932; 1951; Heimbunger, 1934; Plice, 1934; Young, 1934; Donahue, 1940; Diebold, 1941; Eaton and Chandler, 1942; Lutz and Chandler, 1946; Tarm, 1950; Ahlgren and Ahlgren, 1960; Viro, 1974; Bergseth, 1977; Troedsson, 1980; Veneman et al., 1984) show that the most devastating effects of abusive land use has occurred in precisely those landscape elements where forest recovery naturally results in greatest soil acidification.

Figure 9 (altitudinal relationships between vegetation, hydrology, soil and water acidity of the Adirondacks) illustrates that the greatest effects 


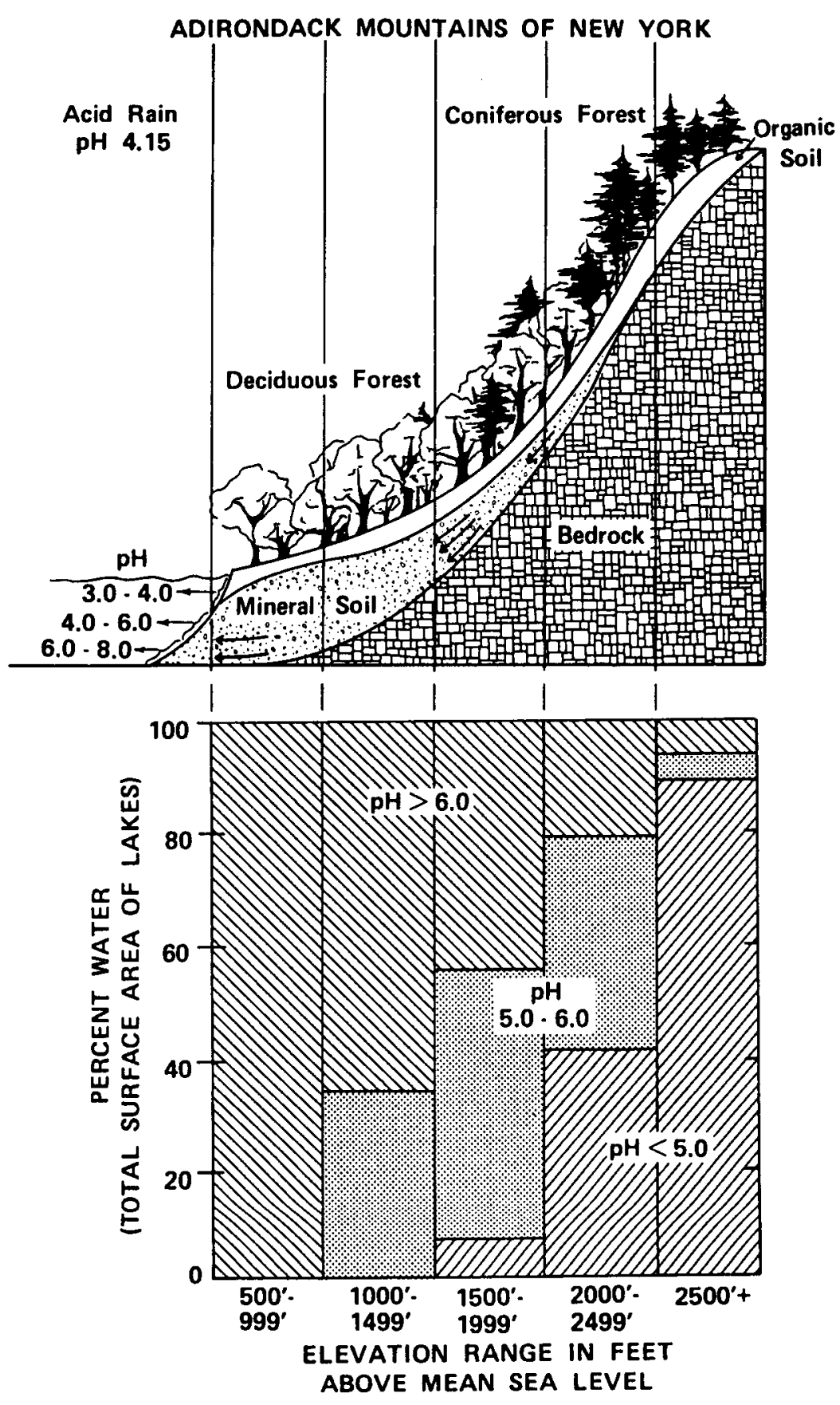

Figure 9. Idealized hydrologic, soil, and vegetation altitudinal gradients of the Adirondack Mountains of New York. Mean pH values of precipitation and runoff components are from Gherini et al. (1985). Hydrologic, soil, and vegetation gradients are idealized from Heimburger (1934), Diebold (1941), Eaton and Chandler (1942), and Lutz and Chandler (1946). The distribution of surface water $\mathrm{pH}$ to altitude is from Pfeiffer and Festa (1980). 
of land-use change on acidification have occurred in precisely those landscape elements where waters are said to be most sensitive to acidification and where acidic waters are most prevalent. It is in these acidic watersheds, whose runoff is through surficial acidic soil materials and whose acidities are greatly influenced by land-use change, where acid rain is believed to be responsible for especially severe and widespread acidification of lakes and streams.

Recovery from earlier disturbance may result in soils that are not yet as acidic as pre-disturbance soils, for example, because of insufficient recovery time to achieve pre-disturbance conditions.

Recovery from earlier disturbance may result in soils that are naturally more acidic than pre-disturbance. For example, based on studies of forest/soil relationships (Griffith et al., 1930; Cain, 1931; Iunt, 1932; 1951; Heimburger, 1934; Plice, 1934; Young, 1934; Donahue, 1940; Diebold, 1941; Eaton and Chandler, 1942; Lutz and Chandler, 1946; Tamm, 1950; Ahlgren and Ahlgren, 1960; Viro, 1974; Bergseth, 1977; Troedsson, 1980; Veneman et al., 1984), it is expected that lower fire frequency and fire intensity will eventually result in soils that are more acidic than pre-disturbance soils. Furthermore, decreased soil thickness due to enhanced erosion caused by disturbance will result in thinner soils which can, in turn, result in soils that become more acidic than the pre-disturbance soils.

Besides resulting in more acidic soils, erosion can change watershed hydrological characteristics so that surface waters receive more near-surface runoff. Thus, it is possible for recovery from disturbance to result in surface waters that are even more acidic than in pre-disturbance times for reasons that are independent of changes in atmospheric acid deposition. 
In summary, the effects of land-use change are essentially ubiquitous in the regions of concern. Furthermore, they appear to have greatest impact in precisely those landscape elements where waters are said to be most sensitive to acidification and where acidic waters are most prevalent. It appears that the effects of acidic deposition are superimposed upon watershed changes induced by recovery from earlier disturbance for many "sensitive" watersheds.

The interaction of acidic deposition with non-steady state watersheds and the influence of such interaction on surface-water acidification have not been adequately evaluated.

Failure to adequately evaluate the effect of land-use changes on surfacewater chemistry could result in serious overestimation of the role of acidic deposition on surface-water acidification. 


\subsubsection{Criticism of the Changing Land-Use Hypothesis}

The National Research Council's (1981) report on "Atmosphere-Biosphere Interactions: Toward a Better Understanding of the Ecological Consequences of Fossil Fuel Combustion" summarily dismissed Rosenqvist's changing land-use hypothesis in one paragraph:

"The theory that the acidification observed in poorly buffered fresh waters was due to changing land-use patterns (Rosenqvist 1978a,b) has now been discounted as an explanation for the widespread effects observed, particularly in remote areas. Detailed study over several years of watersheds in Norway, some with changing land-use patterns and some without, has shown that, on the average, both are acidified at equal rates (Drablos and Sevaldrud 1980, Drablos et al. 1980). Moreover, studies of lakes in North America in areas where land-use patterns have never changed have also shown substantial increases in hydrogen ion or losses in buffering capacity (Dillon et al., 1978, Watt et al., 1979)" (National Research Council, 1981, p.147).

As already discussed in Chapter 3.1 and 3.2 , it cannot be factually said that widespread recent acidification has been observed for Norwegian waters or the Canadian lakes of Dillon et al. (1978). Thus, it seems that the issue of changing land-use patterns not corresponding to "observed" acidification is not a scientific argument.

There are internal inconsistencies within the National Research Council's (1981) report itself that indicate its discounting the effects of land-use change is premature. For example, Figure 2 was published in the National Research Council (1981, p.145) report and shows that the authors of the report believed acidic deposition to be a phenomenon of the 1960's in Scandanavia. But Rosenqvist was using the changing land-use hypothesis to explain acidity-related fisheries problems that began to be reported at least as early as the turn-of-the-century (Dahl, 1927; Braekke, 1976; Rosenqvist, 1978; 1980), a problem that may have always existed to some degree in areas 
of southern Norway (Dahl, 1927; Rosenqvist, 1980). Figure 2 is also inconsistent with Norwegian data showing extensive loss of fisheries prior to 1920 (Dahl, 1927; Braekke, 1976; Rosenqvist, 1978; 1980; Overrein et al., 1980; Figure 5). Likewise, the reported consensus that acidic deposition in Nova Scotia is a recent phenomenon does not account for the earlier acidityrelated fisheries (Chapter 3.2).

As already discussed in Chapter 3.1, the Nova Scotian lakes of watt et al. (1979) may have undergone acidification. But the data used to support the statement about recent acidification shows that acidification can not be caused solely by increased deposition of $\mathrm{H}_{2} \mathrm{SO}_{4}$. The measurements of Watt et al. (1979), when compared to the original measurements of Gorham (1957) for lakes on granite (undisturbed between the sampling dates of 1955 and 1977), show that increase in $\mathrm{H}^{+}$was much larger $(21 \mathrm{ueg} / \mathrm{L})$ than increase in nonmarine $\mathrm{SO}_{42}{ }^{-}(9 \mathrm{ueg} / \mathrm{L})$. Even if the increase in non-marine $\mathrm{SO}_{4}{ }^{2-}$ represented pure $\mathrm{H}_{2} \mathrm{SO}_{4}$, the maximum change in concentration of $\mathrm{H}^{+}$that could be attributed to increased concentration of pure $\mathrm{H}_{2} \mathrm{SO}_{4}$ is 9 ueq/L, not $21 \mathrm{ueq} / \mathrm{L}$ as recorded (Watt et al., 1979). Contrary to the conclusions drawn by Watt et al. (1979) and the National Research Council (1981), these data strongly suggest that acidification of Nova scotian lakes can not be used as definitive proof of acidification solely by acid rain.

It is curious that the National Research Council (1981) and Canadian scientists (Watt et al., 1979) would use the selected Nova Scotian lakes as "proof" against the effects of land-use changes on acidification of surface waters. Gorham (1957), who originally studied these Nova Scotian lakes and whose data Watt et al. (1979) used as the pre-acidification reference state, recognized the earlier land-use history of repeated cutting and burning in 
their watersheds. Gorham (1957) even suggested that such actions in their watersheds influenced their water chemistry and recommended research on the effects of land-use change on water chemistry.

Land classification survey of mainland Nova Scotia showed that of $9,600,000$ acres, only about 200,000 acres of virgin forest or lightly culled hardwood forest remained by 1909-1910 (Fernow et al., 1912; Table 7). Thus, any consideration of historical acidification of surface water in Nova Scotia lakes and salmon rivers (Watt et al., 1979; Thompson et al., 1980), even assuming the data accurately represent such a trend, must consider land-use change to be essentially pervasive in geographic distribution.

Regarding the Nova Scotian lakes studied by Gorham (1957), and later by Watt et al. (1979), Woodward (1906) noted that this part of Nova Scotia was treeless and barren as a result of widespread and very destructive fires set by gold miners to locate gold-bearing rock. The soils of the watersheds of the Nova Scotian lakes are little more than organic matter overlying rock and the miners literally burned the forest and organic soil to bedrock to expose and locate gold-bearing rock (Woodward, 1906; Gorham, 1957). Gold-bearing rock formations pervade the area, some lakes are abandoned quarries, and some bear the names of local gold mines (Gorham, 1957).

Gorham (1957) described the watersheds as having recovered to a large degree from the earlier disturbance. By 1955 the watersheds were described as being heathy spruce forests with peaty soils. He also reported that many of the lakes in 1955 were surrounded by floating mats of sphagnum. Recovery clearly resulted in massive re-acidification of the landscape.

Contrary to the assertions of Watt et al. (1979) and the National Research Council (1981), these Nova Scotian lakes can be used as a textbook case to 
Table 7. Land Classification (1909-1910) Survey

of the Mainland of Nova Scotia.

\begin{tabular}{lrr} 
Classification & Acres & of Land \\
\hline 1. Farm & $1,832,736$ & 19.0 \\
2. Meadow (natural) & 21,680 & 0.2 \\
3. Savanna (open bog) & 37,793 & 0.4 \\
4. Forest & $5,052,838$ & 52.5 \\
a. Conifer & $1,036,175$ & 10.8 \\
$\quad$ Virgin & 31,120 & 0.3 \\
b. Mixed & $3,685,807$ & 38.3 \\
$\quad$ Virgin & 63,376 & 0.7 \\
c. Hardwood & & 3.4 \\
$\quad$ Virgin and moderately cut & 330,856 & 1.2 \\
Recent Burns & 119,883 & 5.8 \\
Old Burns and Barrens & 551,098 & - \\
7. Unclassified & $1,986,354$ & 100.0 \\
8. Total Surveyed & 137,424 & 20.7 \\
\hline
\end{tabular}

Data from Fernow et al. (1912). 
demonstrate the influence of land-use change on the acidity of surface water: disturbance results in loss of acidity and recovery results in acidification. Five of the 21 lake watersheds sampled by Gorham (1957) in 1955 were disturbed prior to the re-sampling made by watt et al. (1979) in 1977 . Four of the five lakes in the disturbed watersheds showed an increase in $\mathrm{pH}$. Of the sixteen that were allowed to continue recovering from earlier disturbance, $\mathrm{pH}$ values became more acidic.

curiously, Havas et al. (1984) referred to the changing land-use hypothesis are a "red herring in acid rain research". Referring to the Gorham (1957) and watt et al. (1979) lakes:

"Of the five watersheds with disturbances, four showed an increase in $\mathrm{pH}$ during the same 22-year period. Such disturbances tend to favor an upward shift in pH." Furthermore,

"Schindler and Ruszczynski (1983) found similar results for lakes in the Experimental Lakes Area in western Ontario between 1973 and 1978. This area is not exposed to acid rain. During the five-year period, $\mathrm{pH}$ increased in many of the lakes that had some disturbances within their drainage basins (i.e., a major windstorm, fire, or clear-cut logging), but remained constant in 'undisturbed' lakes".

"In the White Mountains of New hampshire, forest clearing resulted in a temporary increase in stream water acidity that lasted for two years. The drainage water then became IESS ACIDIC than it was prior to the deforestation (Likens, in press)".

Havas et al. (1984) actually presented a case supporting the changing land-use hypothesis while claiming to disprove it. They showed that disturbance can result in loss of acidity from watersheds where surficial soil processes influence surface water-chemistry. Recovery is expected to result in re-acidification.

In summary, the changing land-use hypothesis of acidification has been widely ignored. Data said to disprove the changing land-use hypothesis actually support it. 
Even the SNSF-Project (the Norwegian forerumner of NAPAP which acknowledges the widespread nature of land-use change and its influence on soil acidity) does not acknowledge land-use change as a major factor in acidification of surface waters (Overrein et al., 1980). A principle reason for this is the reported SNSF-Project summary conclusion of laboratory and field studies that soil acidity is not transmitted to runoff, but acidity from atmospheric $\mathrm{H}_{2} \mathrm{SO}_{4}$ deposition is (Overrein et al., 1980).

The next section of chapter 3 will examine laboratory and field experiments, including those of the SNSF-Project, reported to support the conclusion that acidic $\mathrm{H}_{2} \mathrm{SO}_{4}$ deposition is a necessary condition for the observed acidity of waters (Overrein et al., 1980). 


\subsection{Field and Laboratory Experiments}

\subsubsection{Soil and Plant Ion Exchange}

\subsubsection{SNSF-Project Research and Conclusions}

The SNSF-Project performed a number of field and laboratory experiments to test Rosenqvist's (1978; 1980) alternative hypotheses of acidification. Laboratory experiments were conducted using highly acidic ( $\mathrm{pH}=4.1$ in $\mathrm{H}_{2} \mathrm{O}$ ) humus to determine if neutral salts could yield acidic runoff and, if so, to examine how the acidity of runoff from neutral salt treatment compares to runoff acidity from treatment with similar ionic concentrations of $\mathrm{H}_{2} \mathrm{SO}_{4}$ (Figure 10). Ionic concentrations of $10^{-5} \mathrm{eq} / \mathrm{L}, 10^{-4} \mathrm{eq} / \mathrm{L}$, and $10^{-3} \mathrm{eq} / \mathrm{L}$ sodium chloride (NaCl) and $\mathrm{H}_{2} \mathrm{SO}_{4}$ were used. For $\mathrm{H}_{2} \mathrm{SO}_{4}$ treatment, these concentrations result in $\mathrm{pH} 5,4$, and 3 treatments, respectively. A 1.6 inch thick layer of the $\mathrm{pH} 4.1$ humus was subjected to high rates of leaching $2.4 \mathrm{in./hr}$ up to $7 \mathrm{in.} /$ day (overrein et al., 1980). These experimental conditions of leaching are extremely high, even for periods of high rates of melting snow. For example, 2.4 to $7.0 \mathrm{in./day} \mathrm{runoff} \mathrm{is} \mathrm{equivalent} \mathrm{to} 24$ to 70 inches of snow melting in one day. This is rarely, if ever encountered in nature. Such high rates of leaching are expected to underestimate the influence of soil on runoff chemistry.

For the $10^{-5} \mathrm{eq} / \mathrm{L}$ and $10^{-4} \mathrm{eq} / \mathrm{L}$ treatments of salt and acid, initial $\mathrm{pH}$ of leachate (pH 4.0-4.2) approximated soil pH (4.1). With continued leaching, leachate $\mathrm{pH}$ rose. The salt treatments yielded perhaps slightly more acidic leachate than did equivalent concentrations of acid (Figure 10).

Treatments with $\mathrm{H}_{2} \mathrm{SO}_{4}$ included "resting" the soil. "Rested" soil recovered. Leachate $\mathrm{pH}$ from "rested" soil tended to recover toward the original pH of soil leachate. For the pH 5 and pH 4 treatments, "resting" the soil 


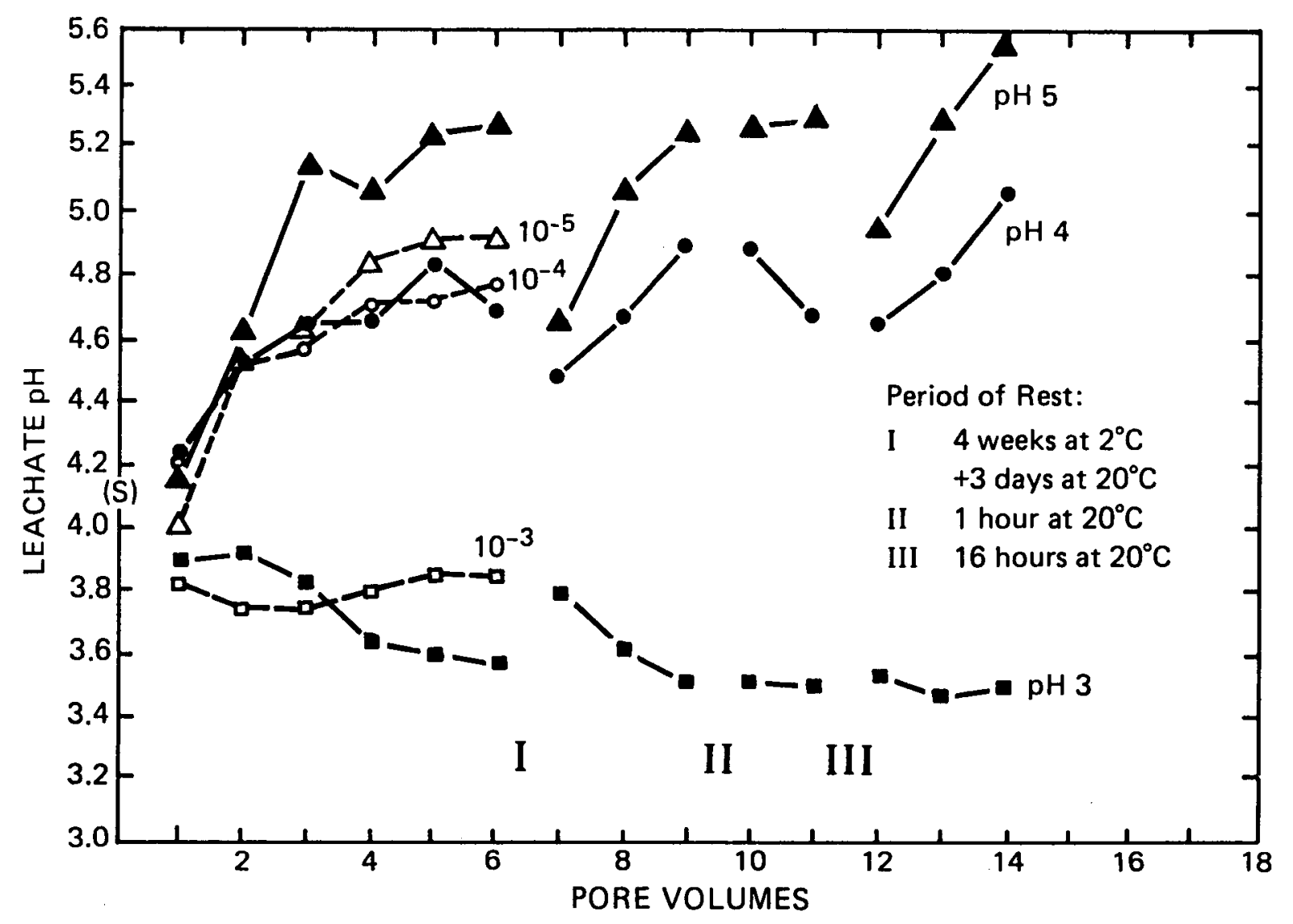

Figure 10. The influence of $10^{-5}, 10^{-4}, 10^{-3} \mathrm{~N} \mathrm{NaCl}(-\cdots), 10^{-5}$ (pH=5) $10^{-4}$ $(\mathrm{pH}=4), 10^{-3} \mathrm{~N}(\mathrm{pH}=3) \mathrm{H}_{2} \mathrm{SO}_{4},(\longrightarrow)$, and rest periods on the $\mathrm{pH}$ of leachate from humus. pH 420 of humus $=4.1$ (S). Each pore volume is equivalent to $30 \mathrm{~mm}$ of precipitation. Modified from Overrein et al. (1980). 
resulted in leachate becoming up to $0.5 \mathrm{pH}$ units more acidic than at the end of the acid treatment (Figure 10).

These data show that highly acidic soil yields highly acidic runoff in the absence of simulated acidic deposition. Neutral salts had about as much influence on the $\mathrm{pH}$ of runoff (leachate) as did similar ionic strength $\mathrm{H}_{2} \mathrm{SO}_{4}$. Furthermore, these data (including "resting" soil) suggest that soil tend to buffer runoff at soil pH (Figure 10).

For the $10^{-3} \mathrm{eq} / \mathrm{L}$ treatments of salt and acid, net overall acidity of the leachates were similar, with $\mathrm{NaCl}$ yielding slightly more acidic leachate in the beginning ( $\mathrm{pH} 3.8$ versus 3.9), and acid treatment yielding more acidic leachate at the end of treatment ( $\mathrm{pH} 3.6$ versus 3.8 for salt) (Figure 10).

It is important to note that while the most acidic precipitation in southern Norway averages above pH 4 (Braekke, 1976), rain at coastal areas of Southern Norway may average about $10^{-3} \mathrm{eq} / \mathrm{L}$ seasalt (Lag, 1968), 20 times greater in ionic concentration relative to the strong acid content of $\mathrm{pH} 4.3$ precipitation. SNSF-Project experiments (Overrein et al., 1980; Figure 10) suggest that seasalts in coastal precipitation can have a larger effect on runoff pH than even the highest current levels of acidic deposition.

other Norwegian studies verified that precipitation containing principally neutral salts can result in highly acidic nunoff (Skartveit, 1980; 1981). In coastal watersheds, relatively unpolluted heavy rainfall events resulted in runoff events with a mean pH of 4.5. The most acidic runoff event observed, $\mathrm{pH}=4.3$ or 50 ueq $\mathrm{H}^{+} / \mathrm{L}$, resulted from rain with only 4 ueq/L of excess (non-marine) $\mathrm{SO}_{4}^{2-}$ (Skartveit, 1980; 1981).

The $10^{-3} \mathrm{eq} / \mathrm{L}$ acid treatment included "resting" the soil. "Rested" soil recovered, issuing less acidic leachate (Figure 10). 
The combined experiments indicate that highly acidic soils tend to buffer runoff around soil $\mathrm{pH}$ and strongly resist chemical change imposed by even abnormally high rates of acidic deposition. While not commented on by SNSF-Project scientists or Rosenqvist, these experiments also suggest that an initial flush of highly acidic water from highly acidic soil may be a natural phenomenon. Thus, the initial flush of highly acidic, near-surface runoff issuing from snowmelt and heavy episodic rain events, which is generally assumed to be from release of stored atmospherically-deposited acids, may simply be a largely natural phenomenon in regions with highly acidic soils.

That highly acidic soils continue to yield highly acidic runoff (leachate) time after time (even from high rates of simulated neutral and alkaline precipitation) and that soils recover after leaching to yield similarly highly acidic runoff (Rosenqvist, 1978; 1980; Overrein et al., 1980; Table 7; Figure 10) indicates that chronic "acidification" of surface waters may simply be a natural phenomenon in some regions whose soils are naturally highly acidic.

Watersheds surrounding streams and lakes are not merely a 1.6 to 4 inch fringe as simulated by Rosenqvist (1978; 1980) and SNSF-Project scientists (Overrein et al., 1980; Figure 10). Accordingly, experiments conducted by both Rosenqvist and SNSF-Project scientists were unnaturally extreme in the rates of precipitation and the very short contact time and distance (inches) between simulated rain and soil. Such experiments necessarily overrepresent possible influences of atmospheric deposition on runoff chemistry. Under less severe conditions, soils and other natural factors may exert even greater control on runoff chemistry than demonstrated in these experiments.

This series of experiments verify Rosenqvist's hypothesis that electrolyte 
concentration of rain is more important than its acidity, per se, and soil $\mathrm{pH}$ has an even greater effect on runoff $\mathrm{pH}$ than total electrolyte content of precipitation.

A number of other experiments were carried out to examine the effects of soil and chemical composition of snow on the chemistry of snowmelt runoff. Soils were put in troughs 1 meter long and frozen. Snowpack of differing acidities were placed on top of frozen soil, the trough inclined 30 degrees, and allowed to melt by placement in a room at 8 degrees celsius $\left({ }^{\circ} \mathrm{C}\right)$ (Overrein et al., 1980).

It was found that the effect of snow composition had little effect on snowmelt $\mathrm{pH}$. Snowmelt was about $\mathrm{pH} 4$ coming from humus with heather, about pH 6 for snowmelt derived from loamy mineral soil (typical of farm fields) regardless of the initial acidity of the original snowpack (Overrein et al., 1980) •

This series of snow/trough experiments can also be considered to be extreme in that it predisposes the results toward overestimating the effects of snow chemistry on acidity of runoff. In "sensitive" regions where it is believed that waters have been acidified by acidic deposition, field observations indicate that soil rarely freezes under snowpack (Likens et al., 1977). Furthermore, runoff has to travel well over 1 meter before entering surface waters. Thus, the influence of soils on controlling the acidity of snowmelt may be even greater than depicted in the snow/trough experiments.

Most landscapes are quite heterogeneous in respect to soils, vegetation, and hydrology. Seip et al. (1979a) concluded that, because of such landscape heterogeneity, acidification of runoff by atmospheric deposition is difficult to observe in watersheds as small as $0.1 \mathrm{~km}^{2}$ (about 25 acres). This 
conclusion supports Rosenqvist's $(1978 ; 1980)$ observation about the lack of correlation of precipitation $\mathrm{pH}$ with the $\mathrm{pH}$ of runoff for a SNSF-Project stream. Accordingly, the SNSF-Project established mini-catchments with which to better understand the relationship of precipitation chemistry to the acidity of runoff. The mini-catchments ranged from $30 \mathrm{~m}^{2}$ to $264 \mathrm{~m}^{2}$ : equivalent in area from a $18^{\prime} \times 1^{\prime}$ room to a $53^{\prime} \times 53^{\prime}$ house. From $46 \%$ to $74 \%$ of the mini-catchments were exposed (principally granite) "barren" bedrock (Seip et al., 1979a). Because of their small size, large percentage of bare bedrock, and only shallow patches of soil, they represent nature's version (as opposed to the artificial snow/trough system) of the worst case scenario. The influence of atmospheric deposition should be most easily demonstrated here.

Rosenqvist's (1978) hypothesis about snowmelt chemistry being principally controlled by soil acidity was tested again in mini-catchments (Seip et al., 1980). Mean snowpack pH was 4.3 in both 1978 and 1979. The 1979 snowpack was neutralized to about $\mathrm{pH} 7$ with sodium hydroxide (NaOH). Runoff from snowpack in both years had a initial flush of highly acidic pH. While 1978 runoff chemistry was not reported, seip et al. (1980) concluded that the acidity of runoff was essentially the same in both years, and perhaps slightly more acidic in 1979, the year that snowpack was neutralized. Mean snowmelt chemistry for the $\mathrm{pH} 7.0$ snowpack is reported in Table 8. Mean $\mathrm{pH}$ of snowmelt was from pH 7.0 snowpack was 4.43 (Table 8).

The mini-catchments were also used to study the relationship between the $\mathrm{pH}$ of rain and runoff. Runoff was reported as having much more acidic pH values than the rain that resulted in runoff (Seip et al., 1979a). Runoff pH correlated well with soil $\mathrm{pH}$, i.e. the more acidic the soil in the 
mini-catchment, the more acidic was mean runoff pH (Seip et al., 1979a). only for the smallest mini-catchments, and only for heaviest rains, was there reported to be any measurable relationship between precipitation $\mathrm{pH}$ and runoff $\mathrm{pH}$ (Seip et al., 1979a). The only data published by seip et al. (1979a) on the relationship of comprehensive mean precipitation chemistry to comprehensive mean runoff chemistry are presented in Table 9. Some watershed characteristics of the corresponding two mini-catchments are given in Table 10. These data show that runoff $\mathrm{pH}$ is at least two times more acidic than the $\mathrm{pH}$ of rain (Table 9). Runoff pH correlates to soil pH (Table 9; 10), as concluded by seip et al. (1979a). Certain characteristics of the minicatchments appear to exert major influence on the chemistry of runoff: the larger the mini-catchment and the greater the percentage of soil cover and the greater the soil acidity, the more acidic the runoff (Table 9; 10).

Seip et al. (1979a) concluded:

"In soils with low $\mathrm{pH}$ and $\mathrm{H}^{+}$as the dominant exchangeable cation, the $\mathrm{pH}$ in the run-off must most likely be low. The run-off from the plots may therefore be more acid than the precipitation." Furthermore, "It is likely that the total amounts of ions in the precipitation are more important than the $\mathrm{H}^{+}$- concentration alone in this connection."

Simulated pH 3.85 and unpolluted "rain" were sprayed on Norwegian minicatchments and the relative acidities of their runoff were compared. It was found that pH 3.85 "rain" could acidify runoff from mini-catchments by 0.2-0.4 pH units relative to $\mathrm{pH}$ 5.0-5.3 "rain". It was concluded that this $\mathrm{pH}$ effect was due to differences in the total ionic concentration of simulated $\mathrm{pH} 3.85$ precipitation (141 ueg/L of $\mathrm{H}^{+}$) and simulated unpolluted precipitation (Seip et al., 1979b) .

To summarize, SNSF-Project laboratory and field experiments also verifies Rosenqvist's (1978; 1980) hypothesis that electrolyte concentration of rain 
Table 8. Mean Water Chemistry Data for Snowmelt from pH 7.0 Snowpack in a Norwegian Mini-Catchment.

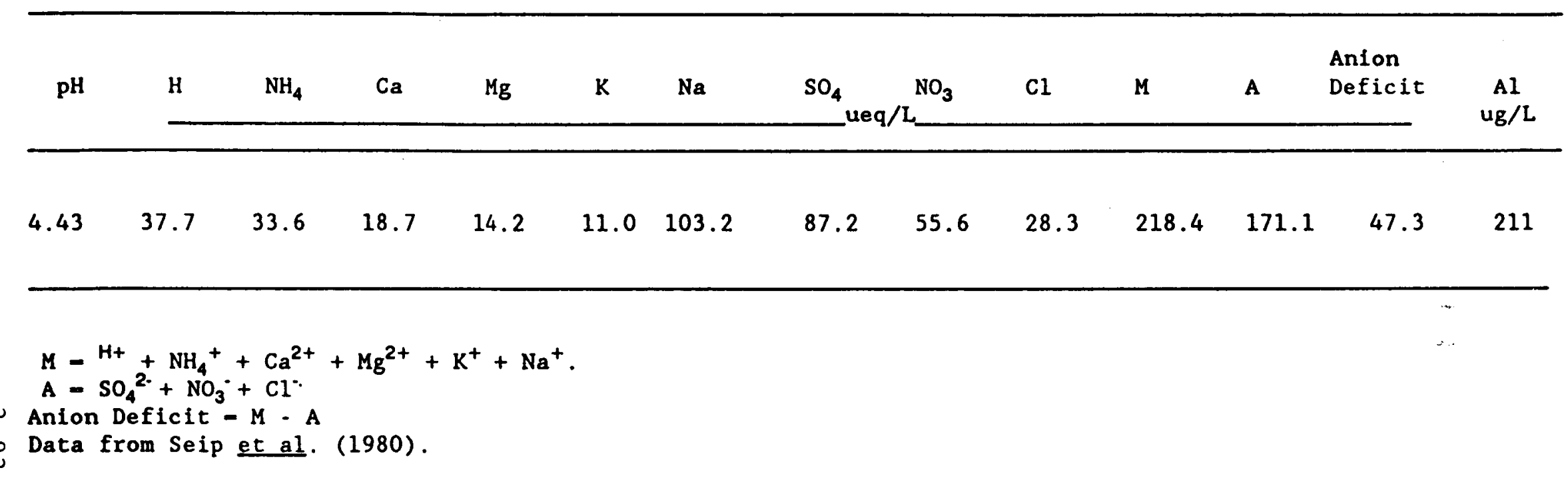


Table 9. Mean Rain and Runoff Chemistry Reported for Norwegian Mini-Catchments.

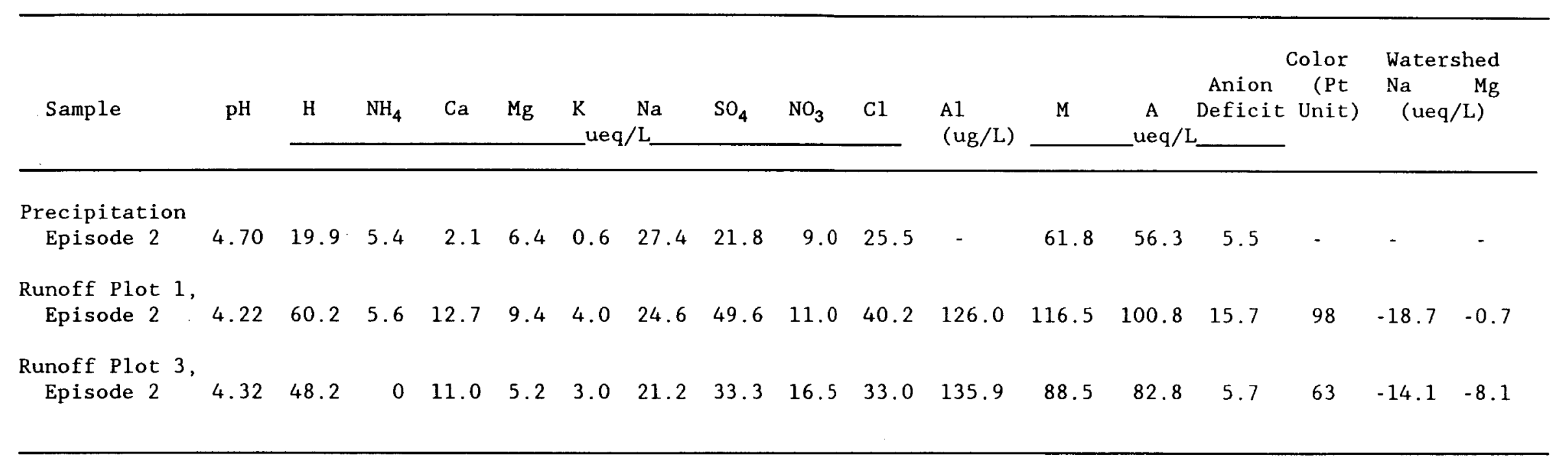

$\mathrm{M}=\mathrm{H}^{+}+\mathrm{NH}_{4}^{+}+\mathrm{Ca}^{2+}+\mathrm{Mg}^{2+}+\mathrm{K}^{+}+\mathrm{Na}^{+}$.

$\mathrm{A}=\mathrm{SO}_{4}{ }^{2-}+\mathrm{NO}_{3}{ }^{\circ}+\mathrm{Cl}^{*}$

Anion Deficit $=M-A$.

Watershed $\mathrm{Na}=\mathrm{Na}_{\text {runoff }}-{\frac{\mathrm{Cl}}{\mathrm{Cl}_{\text {ranoff }}}}_{\mathrm{XNa}} \mathrm{Na}_{\text {rain }}$.

Watershed $\mathrm{Mg}=\mathrm{Mg}_{\text {runoff }}-\quad \frac{\mathrm{Cl}}{\mathrm{Cl}_{\text {rainoff }}} \times \mathrm{Mg}_{\text {rain }}$.

Watershed $\mathrm{Na}$ and $\mathrm{Mg}$ assumes runoff $\mathrm{Cl}^{-}$comes only from atmospheric deposition and atmospheric deposition contributions of $\mathrm{Na}$ and $\mathrm{Mg}$ are in the same proportion as the $\mathrm{Na} / \mathrm{Cl}$ and $\mathrm{Mg} / \mathrm{Cl}$, ratios in precipitation.

Data from Seip et a1. (1979a). 
Table 10. Some Characteristics of Norwegian Mini-Catchments 1 and 2 whose Runoff Chemistry was Described in Table 9.

\begin{tabular}{cccc}
\hline Mini-Catchment & $\begin{array}{c}\text { Area } \\
\left(\mathrm{m}^{2}\right)\end{array}$ & $\begin{array}{c}\text { Mean Soil pH } \\
\left(\mathrm{H}_{2} \mathrm{O}\right)\end{array}$ & $\begin{array}{c}\text { Barren Rock } \\
(8)\end{array}$ \\
\hline 1 & 264 & 4.1 & 61 \\
2 & 30 & 4.4 & 74 \\
\hline
\end{tabular}

Soil $\mathrm{pH}$ determined in pure water at soil/water volume ratio of $1: 2.5$. Data from Seip et al. (1979a). 
is more important than its acidity, per se, and soil $\mathrm{pH}$ has an even greater effect on $\mathrm{pH}$ of runoff than does total electrolyte content in precipitation.

Nevertheless, the summary conclusion of SNSF-Project laboratory and field studies in the Final Report of the SNSF-Project (Oerrein et al., 1980) summarily dismisses Rosenqvist's (1978; 1980) hypotheses of natural watershed acidification. It concludes that $\mathrm{H}^{+}$from highly acidic soils is not transmitted to runoff but $\mathrm{H}^{+}$from atmospheric deposition (particularly $\mathrm{H}_{2} \mathrm{SO}_{4}$ ) is:

"The easiest way to understand the recent acidification of freshwater is by using the mobile anion concept. While most of the atmospheric nitrate is retained in the catchment, sulphate anions are usually quite mobile. The increased concentration of cations, including $\mathrm{H}^{+}$, resulting from an increase in the sulphate concentrations in runoff, explain at least a substantial part of the observed acidification "(Overrein et al., 1980, p.110).

It is quite clear that field and laboratory evidence does not allow Rosenqvist's hypothesis to be summarily dismissed. Rosenqvist's hypothesis appears to have been rejected simply because it does not support the conclusion of widespread and detrimental aquatic effects of acidic deposition.

The acidification theory cited above and established by the end of the SNSF-Project (Overrein et al., 1980) is the theory of surface-water acidification. Watersheds were claimed to be steady-state filters of varying efficiency in neutralizing inputs of acid. Near-surface runoff through organic rich, highly acidic surficial soil horizons, peats, and their associated acidophilic ecosystems are considered to be highly inefficient in neutralizing acidic deposition by processes of ion exchange or mineral weathering. For one, they are acid-rich and base poor, therefore have little bases with to buffer inputs of acid (i.e., they have $F$ values that approach 
0). Humic acids are recognized as strongly reacting with and, thereby, inactivating ionic aluminum and iron that can physicochemically retain $\mathrm{SO}_{4}{ }^{2-}$. Considerations of acidic deposition/watershed interactions involve humic acids only to the extent of those interactions that enable the efficient passage of deposited $\mathrm{H}^{+}$and $\mathrm{SO}_{4}{ }^{2-}$ through watersheds. Thus, highly acidic, organic-rich soils and peats and their associated acidophilic ecosystems are theorized as being incapable of acidifying runoff. Accordingly, acidic, near-surface runoff is stated to be acidified by acidic deposition (Seip and Tollan, 1978; Overrein et al., 1980; Seip, 1980). These considerations of acidic deposition/watershed interactions are the foundation of $\mathrm{H}$-ion input/output budgets of current acidification theory (e.g., Johnson et al., 1981; Driscoll and Likens, 1982; Nilsson et al., 1982; Van Breemen et al., 1984 ; 1985; Reuss et al., 1986; 1987; De Vries and Breeuwsma, 1987).

Formally, however, there is an inconsistency (Krug, 1985) in that the role of organic acids and complexation of organic acids in acidifying soil and watersheds is not considered in regard to H-ion budgets used to compare the magnitude of acidic deposition to internal acidification processes (Seip, 1980; Overrein et al., 1980; Johnson et al., 1981; National Research Council, 1981; Driscoll and Likens, 1982; Nilsson et al., 1982; Havas et al., 1984; Peterson, 1984; Van Breemen et al., 1984; Neal et al., 1986; Reuss et al., 1986; 1987; De Vries and Breeuwsma, 1987). Acidification of watersheds is considered to be determined by net loss of bases which is defined in $\mathrm{H}$-ion watershed budgets as loss of ANC (acid neutralizing capacity) from the watershed. Thus limestone, and similar terrain, with high rates of mineral weathering that export much mineral bases and alkalinity in their runoff are defined as highly acidifying watersheds. Granitic watersheds with low rates 
of mineral weathering and alkalinity production are considered to be but slightly acidifying (Seip, 1980; Overrein et al., 1980; Johnson et al., 1981; National Research Council, 1981; Driscoll and Likens, 1982; Nilsson et al., 1982; Havas et al., 1984; Peterson, 1984; Van Breemen et al., 1984; Neal et al., 1986; Reuss et al., 1986; 1987; De Vries and Breeuwsma, 1987).

That limestone, and similar terrains are considered by $\mathrm{H}$-ion budgets to be "highly acidifying" while granitic, and similar terrains are considered to be "slightly acidifying (Seip, 1980; Overrein et al., 1980; Johnson et al., 1981; National Research Council, 1981; Driscoll and Likens, 1982; Nilsson et al., 1982; Havas et al., 1984; Neal et al., 1986; Peterson, 1984; Van Breemen et al., 1984; Reuss et al., 1986; 1987; De Vries and Breeuwsma, 1987). That granitic landscapes in many "sensitive" watersheds in eastern North America and northern Europe have highly acidic, organic-rich soils and peats with acidity equivalent of 1,000's of years of high rates of acidic deposition is not recognized by H-ion budgets (Seip, 1980; Overrein et al., 1980; Johnson et al., 1981; National Research Council, 1981; Driscoll and Likens, 1982; Nilsson et al., 1982; Havas et al., 1984; Peterson, 1984; Van Breemen et al., 1984; Neal et al., 1986; Reuss et al., 1986; 1987; De Vries and Breeuwsma, 1987).

In summary, this assumption/conclusion is internally inconsistent, counter-intuitive as well as counter-real-world-observational. Nevertheless, this reasoning is basic to the determination of how acidic deposition/watershed interactions are defined by $\mathrm{H}$-ion budgets incorporated into current acidification theory and dynamic acidification models (Krug, $1985 ; 1987 ; 1988)$.

It is quite clear that SNSF-Project field and laboratory evidence does not 
support the theory of surface-water acidification. It does not attempt to consider watershed processes and conditions that enable the theory to be consistent with field and laboratory results showing strong acidification of surface-waters by natural watershed processes. Nevertheless, the theory of surface-water acidification appears to be accepted and Rosenqvist's hypothesis appears to be rejected on the basis of their agreement or disagreement with the conclusion that widespread and detrimental aquatic effects of acidic deposition have occurred. 
3.7.1.2 Alternative Hypothesis of Acidification by Soil and Plant Ion Exchange

The hypothesis that soil and plant ion exchange can produce highly acidic water on a sustained basis by converting neutral salts to strong mineral acids is supported by the field and laboratory studies discussed in Chapter 3.7.1.1, the existence of life, watersheds, and highly acidic soils.

In respect to ion exchange, the theory of acidification implicitly considers watersheds to be literal analogs to the laboratory ion exchange column. Watersheds and their soils are theorized as being closed systems where all inputs and outputs are ionic except, of course, for water and atmospheric gases (Overrein et al., 1980; Seip, 1980; Johnson et al., 1981; Driscoll and Likens, 1982; U.S. EPA, 1984; NAPAP, 1984; 1986; 1987a; 1988; Van Bremmen et al., 1984; 1985; Berden et al., 1987; Reuss et al., 1987). As discussed in Chapter 3.7.1.1, ion exchange of neutral salts with plants and acidic soils is considered to be incapable of sustained acidification of runoff (Overrein et al., 1980; Seip, 1980; Johnson et al., 1981; Driscoll and Likens, 1982; U.S. EPA, 1984; NAPAP, 1984; 1986; 1987a; 1988; Van Bremmen et al., 1984; 1985; Berden et al., 1987; Reuss et al., 1987). Continued input of neutral salt is defined as saturating and neutralizing the acid soil system: as happens with $\mathrm{H}^{+}$ion exchange resin that is trapped and sealed inside the canister of the laboratory ion exchange column:

$$
\begin{aligned}
& \text { 1. } \mathrm{H}^{+} \mathrm{Soil}^{-}+\mathrm{M}^{+}+\mathrm{Cl}^{-}=\mathrm{M}^{+} \mathrm{Soil}^{-}+\mathrm{H}^{+}+\mathrm{Cl}^{-} \text {; }
\end{aligned}
$$

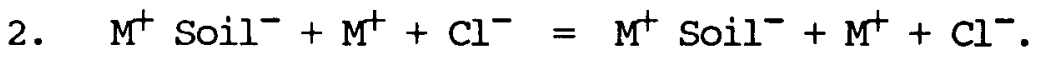

The theory of acidification predicts that, eventually, in the absence of acidic deposition, the $\mathrm{H}^{+}$in watershed soils (like the $\mathrm{H}^{+}$in the laboratory ion exchange resin) becomes "spent" (replaced with other cations) and the 
watershed can not impart acid to water (Overrein et al., 1980; Seip, 1980; Johnson et al., 1981; Driscoll and Likens, 1982; Van Bremmen et al., 1984; 1985; Berden et al., 1987; Reuss et al., 1987).

Unfortunately, the very existence of highly acidic soils invalidates the theory of acidification. By this theory, the existence of such soils is impossible because they have been receiving input of thousands of years of such non-acidic deposition. The acidity $\left(\mathrm{H}^{+}\right)$in the soil should have been "spent" a long time ago. Nevertheless, the highly acidic soils common to "sensitive" watersheds of Scandanavia and areas of eastern North America have an acid content equivalent to thousands of years of current levels of highly acidic deposition (Griffith et al., 1930; Heimberger, 1934; Plice, 1934; Lutz and Chandler, 1946; Tanm, 1950; Bergseth, 1977; Rosenqvist, 1978; 1980; Troedsson, 1980; Krug and Frink, 1983a, b). Such high levels of soil acidity can not be accounted for by recent man-made acidic deposition. Thus, the highly acidic soils of many "sensitive" regions of northern Europe and eastern North America must be naturally acidic.

The very process of life itself also invalidates the theory of acidification. For plants to live, they must take up mineral nutrient cations and anions. Because plants take up more cations than anions, the net result of nutrient uptake process is one of acidification since nutrient cations taken out of solution (plant ion exchange) are replaced by $\mathrm{H}^{+}$(Clymo, 1963; 1984; Rosenqvist, 1978; 1980; Driscoll and Likens, 1982; Nilsson et al., 1982; Krug et al., 1985; Rush et al., 1985; Neal et al., 1986). Thus the very process of nutrient uptake by plant life is one of acidification of water.

Unlike the closed laboratory ion exchange column whose $\mathrm{H}^{+}$ion exchange 
resin is fixed and contained, new "H+ ion exchange resin" is constantly being created by process of life.

Also, unlike the laboratory acid exchange resin, the original "resin" (biomass) is further modified by biochemical processes upon its death. In many "sensitive" watersheds, it is partially oxidized to create more acid: organic acids that are collectively known as humic acids. The creation of these additional (humic) acids does not lend itself to ion input/output budgets either. Organic acids are created by partial oxidation of biomass. The ultimate source of their $\mathrm{H}^{+}$is the non-ionic hydrogen of water $\left(\mathrm{H}_{2} \mathrm{O}\right)$. Thus, input of ionic hydrogen is not involved in the creation of organic acids.

The world is not made solely of ionic compounds (salts and mineral acids) and, therefore, can not be realistically described in terms of ion input/output budgets, as is done in studies of acidic deposition/watershed interaction. Elements (such as hydrogen) in non-ionic compounds can be chemically transformed into ionic compounds. Indeed, this is the process by which acid rain itself is created: acid $\left(\mathrm{H}^{+}\right)$is created from non-ionic hydrogen in fossil biomass and water by oxidation which transforms covalently-bound hydrogen to more ionic forms. combustion and the creation of acid rain involve such oxidation of non-ionic hydrogen, much as naturally occurs in "sensitive" watersheds with the creation of highly acidic soil organic matter. Thus, the creation of acid rain itself, like soil acidity, can not be realistically described in terms of hydrogen ion input/output budgets, as is done in studies of acidic deposition/watershed interaction.

The physical existence of watersheds also invalidates the theory of acidification. Watersheds and topography are created by erosional and 
depositional processes: processes that remove "spent" resin. This is why we have watersheds and drainage patterns. This is why lakes and ponds fill up. Unlike the laboratory ion exchange column, nature automatically and continuously produces fresh $\mathrm{H}^{+}$"ion exchange resin" and continuously removes spent "ion exchange resin". According to acidification theory, however, the dynamic biogeochemical processes of watersheds that enable soil and plant ion exchange to acidify water are assumed to be static or non-existent and, thereby, incapable of sustained acidification of water (Overrein et al., 1980; Seip, 1980; Johnson et al., 1981; Driscoll and Iikens, 1982; U.S. EPA, 1984; NAPAP, 1984; 1986; 1987a; 1988; Van Brenmen et al., 1984; 1985; Berden et al., 1987; Reuss et al., 1987).

These omissions of and erroneous considerations of biogeochemical processes from acidification theory are not random. Omission and errors are consistently those that necessitate overestimation of aquatic acidification by acid rain.

The following research results illustrate that biological processes can have a significant influence on the acidity of water even in environments that are commonly perceived as essentially "lifeless". Natural landscape development from such barren and "lifeless" landscapes is also illustrative of acidification and other natural watershed processes.

Accordingly to acidification theory, soils in "sensitive" landscapes are essentially transparent to acidic deposition: they are theorized as doing little to influence acid/base chemistry of acidic deposition passing through them. Also, exposed granitic rock, such as in the Norwegian mini-catchment studies, are often considered "barren". But even exposed granitic bedrock is not without life and the erosional/depositional processes required for 
natural acidification.

Cormonly, exposed bedrock has patches of lichens and moss. Lichens represent the start of biological colonization that will eventually transform exposed bedrock to soil. In this process, lichens survive by taking nutrients out of rain, melting snow, and weathering rock (which they help to weather). This life process is one of acidification (the net exchange of $\mathrm{H}^{+}$ for positive ions taken up as nutrients).

Abrahamsen et al. (1978) researched the interaction of simulated precipitation with "barren" bedrock having only $20 \%$ lichen cover. The $\mathrm{pH}$ of runoff was found to be both a function of neutral salt/biological ion exchange and the acid content of simulated rain. Runoff from simulated pH-5 rain with concentrations of neutral salts typical of local precipitation was initially $\mathrm{pH}$ 4.1-4.3 and increased with time to $\mathrm{pH} 4.6-4.7$ (Figure 11). When this simulated pH -5 "rain" was replaced by "rain" without neutral salts, runoff $\mathrm{pH}$ quickly rose to about $\mathrm{pH}-5$, the $\mathrm{pH}$ of "rain" (Figure 11). Application of pH 4.3 "rain", which is approximately the mean annual pH of annual precipitation in southernmost Norway, resulted in pH 4.3 nunoff (Abrahamsen et al., 1978).

The results from "barren" bedrock (Abrahamsen et al., 1978) are unlike the mini-catchment and soil leaching experiments of the SNSF-Project documented in Chapter 3.7.1.1 where there is little or no measurable change between control treatments and simulated ambient levels of acidic deposition (Seip et al., 1979a; 1980; Overrein et al., 1980). Despite assertions otherwise, the data show that highly acidic soil systems are decidedly robust in their ability to acidify/buffer runoff. They display homeostasis, resisting change. Exposed granite-like bedrock exerts less influence than does soil on 


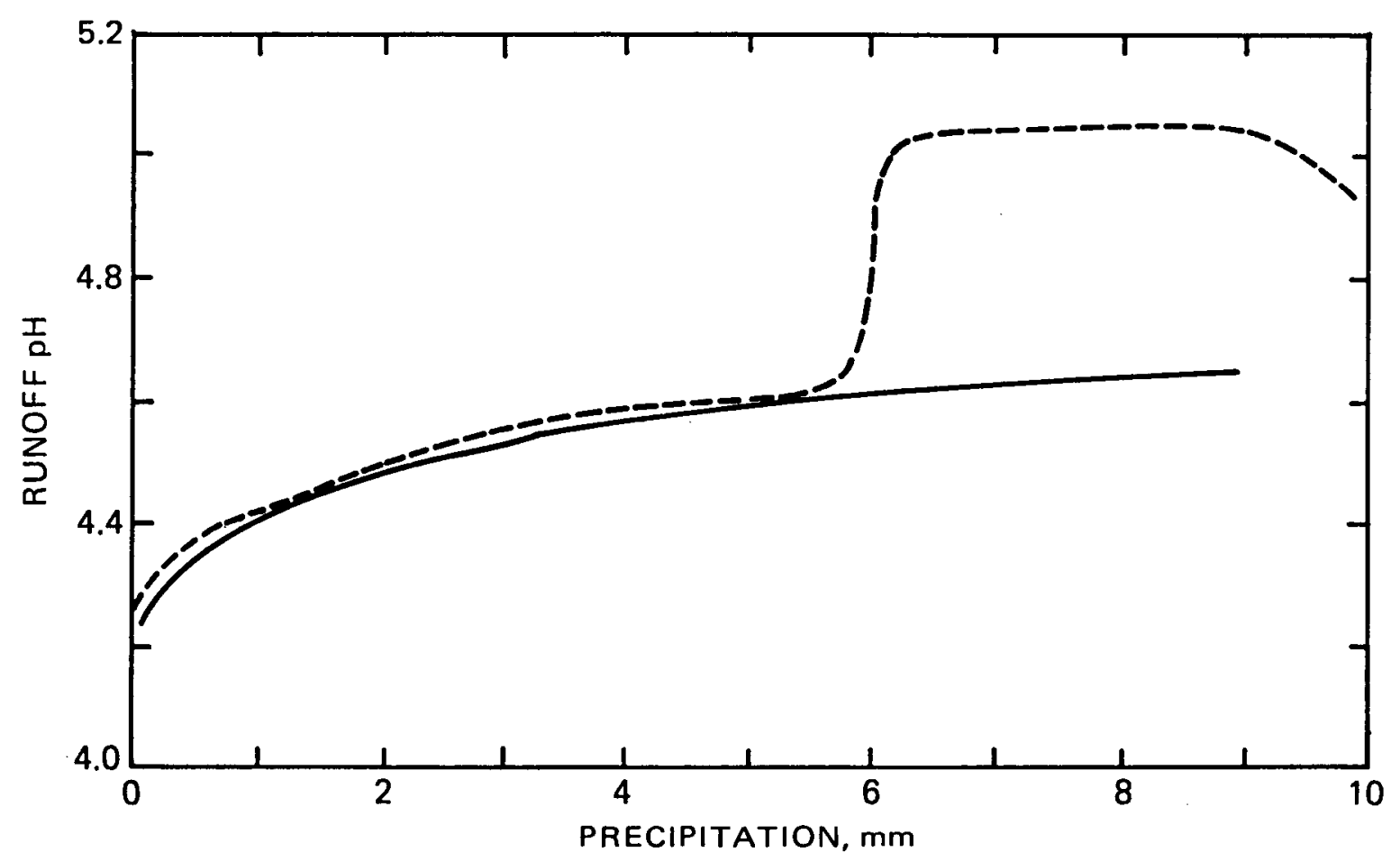

Figure 11. The effect of simulated pH 5 with normal background level of salt (_ ) and, partly through the experiment, without salt (---) on runoff pH from "barren" bedrock with $20 \%$ lichen cover in southern Norway. Modified from Overrein et al. (1980). 
runoff chemistry. However, net acidification is not $50 \mathrm{ueq} \mathrm{H}^{+} / \mathrm{L}$, as expected from acidification theory, but only about 25 ueq $\mathrm{H}^{+} / \mathrm{L}$, i.e., from $\mathrm{pH}$ 4.6-4.7 to $\mathrm{pH} 4.3$ (Abrahamsen et al., 1978). Net acidification of initial runoff may even be less as unpolluted simulated rain resulted in $\mathrm{pH} \sim 4.3$ runoff. Whether this initial flush of acidity is natural (the result of initially high rates of nutrient uptake that diminish as lichens satiate their demands for food) or the result of stored anthropogenic acidity is unclear.

Thus, even this supposedly unreactive landscape element ("barren" granitic rock) naturally acidifies and resists change; it displays homeostasis.

The next successional stage is occupation by mosses. Here, even greater acidification/buffering is observed. For example, pools on exposed granite in Australia have a pH of about 6.4, except when occupied by the mosses Isoetes sp. and Campylopus bicolor. When mosses are present, water pH values are 3.7-3.8, apparently due to plant ion exchange (Bayley, 1982).

Another study of exposed granite-like rock in Norway involved the effect of patches of moss on the $\mathrm{pH}$ of snowmelt from exposed granite-like rock. Rueslatten and Jorgensen (1978) found that patches of moss acidify pH 4.9-5.0 snowmelt to $\mathrm{pH}$ 3.9. However, after the $\mathrm{pH} 3.9$ runoff from the moss runs 50 meters over the rock, runoff $\mathrm{pH}$ rises to about $\mathrm{pH} 4.5$.

Greater acidification also results in greater rates of mineral weathering by acids. In this case, about $75 \%$ of the acid from moss runoff is neutralized, apparently by mineral weathering (Rueslatten and Jorgensen, 1978). In the aquatic effects literature, if $75 \%$ of $\mathrm{H}_{2} \mathrm{SO}_{4}$ deposition is converted in a watershed to basic $\mathrm{SO}_{4}{ }^{2-}$, i.e. $\left(\mathrm{Ca}^{2+}+\mathrm{Mg}^{2+}+\mathrm{K}^{+}+\mathrm{Na}^{+}\right) \mathrm{SO}_{4}{ }^{2-}$, the watershed is said to have a F-factor (or value) of 0.75 . 
Enhancing mineral weathering by acidification appears to be a way that ecosystems modify the enviromment to enhance the supply of nutrients that they need to live, especially acidophilic ecosystems in base-poor and nutrient-poor environments. It also results in accelerated soil formation. The greater biological activity of mosses relative to lichens can result in the accelerated development of mineral soil (by physicochemical weathering of rock). Greater biomass production can also help to develop the humic acid rich soils that tend to develop in rocky terrains of "sensitive" regions (Cain, 1931; Heimburger, 1934; Diebold, 1941; Lutz and Chandler, 1946; Bergseth 1977; Troedsson, 1980).

The next sequence of stages in landscape development is the shallow soil/ecosystem successional sequences, like those seen in the Norwegian minicatchments. As already discussed, these systems are even more robust in their homeostasis, their ability to resist change. Ambient levels of acidic deposition produce little or no measurable change in runoff acidity from the rocky mini-catchments (Seip et al., 1979a; 1980; Overrein et al., 1980; Table $8 ; 9 ; 10)$. The absence or presence of acidic deposition seems to make little or no measurable difference in the acidity of runoff (Seip et al., 1979a; 1980; Overrein et al., 1980; Table $8 ; 9 ; 10)$, contrary to what the theory of acidification predicts. Apparently, one of the reasons why levels of acidic deposition have so little influence on the acidity of runoff from Norwegian mini-catchments is that runoff is naturally acidic due to acidification by ion exchange. Nevertheless, Rosenqvist's hypothesis $(1978 ; 1980)$ predicts that there will be measurable acidification by acidic deposition. Therefore, Rosenqvist's (1978; 1980) ion exchange hypothesis (which accounts for the Ffactor due to ion exchange) apparently underestimates natural 
acidification/buffering processes of watersheds and does not take into consideration all watershed processes of acidification and buffering.

Nevertheless, acidification of runoff from Norwegian min-catchments by ion exchange is apparent. Table 9 shows that concentrations of sodium (Na) and magnesium (Mg) in runoff are less than values predicted from atmospheric inputs alone. On the basis of hydrogen ion budgets or ionic input/output budgets, watersheds contribute negative concentrations of $\mathrm{Na}$ and $\mathrm{Mg}$ to runoff. Negative concentrations are a physical impossibility.

Objective analysis of Table 9 data suggest that the mini-catchment is storing and/or eroding (in particulate form) atmospherically-deposited $\mathrm{Na}$ and Mg as well as some $\mathrm{Na}, \mathrm{Mg}, \mathrm{K}$, and $\mathrm{Ca}$ produced by mineral weathering. Net negative concentrations of $\mathrm{Na}$ and $\mathrm{Mg}$ mean that even rates of mineral weathering can not meet with the ion exchange uptake demands and/or erosional output of the watershed. The net uptake of $\mathrm{Na}$ and $\mathrm{Mg}$ and replacement with $\mathrm{H}^{+}$ is about $20 \mathrm{ueg} / \mathrm{L}$, which is the same as the input of $\mathrm{H}+$ from the $\mathrm{pH} 4.7$ acid rain (Table 9). But some indeterminant portion of the acid rain input of 20 ueq $\mathrm{H}^{+} / \mathrm{L}$ is necessarily consumed by mineral weathering. Atmospheric input of $\mathrm{H}^{+}$necessarily increases concentrations of mineral base cations in runoff. So, for example, $\mathrm{pH} 4.7$ acidic deposition is expected to contribute less than its full 20 ueq $\mathrm{H}^{+} / \mathrm{L}$ to runoff because some of its $\mathrm{H}^{+}$is retained in the watershed and replaced by base mineral cations in runoff (F-factor). Enhanced leaching of base mineral cations (F-factor) by acidic deposition masks the true degree of net contribution of $\mathrm{H}^{+}$to runoff by ion exchange, i.e., the net acidification of water by ion exchange before acidic deposition.

Enhanced leaching of base mineral cations resulting from acidic deposition 
(F-factor) is yet another example of how acidification by acid rain can be overestimated, and natural processes of acidification can be underestimated, by not considering factors that act to neutralize or buffer acidic deposition.

Apparently, naturally-acidic lakes existed in Nova Scotia in 1955 acidified by both weak organic acids and strong acids (Gorham, 1957; Table 11). Natural strong acid production may be by both soil and plant ion exchange, given the descriptions of the watersheds (heathy peaty forested watersheds with lakes often surrounded by sphagnum peats and lakes containing floating sphagmum mats (Gorham, 1957)). Mean concentration of non-marine Mg in lakewater (an estimate of net watershed mineral weathering contribution of Mg) is negative (Table 11) which indicates net strong acid production by ion exchange.

Watt et al. (1979) claimed that Nova Scotian lakes surveyed earlier by Gorham (1957) had subsequently become acidified by acidic deposition. They claimed that acidification of these Nova Scotian lakes was consistent with $\mathrm{H}_{2} \mathrm{SO}_{4}$ titration loss of alkalinity because of the increase in concentrations of non-marine $\mathrm{SO}_{4}{ }^{2-}$ and $\mathrm{H}^{+}$in lakewaters between 1955 and 1977 (Watt et al., 1979) .

Table 11 shows that mean concentration of non-marine $\mathrm{SO}_{4}{ }^{2-}$ for lakes on granite increased by 9.3 ueg/L whereas concentration of $\mathrm{H}^{+}$increased by 21.1 ueq/L (Table 11). Acidification theory considers increased concentration of non-marine $\mathrm{Ca}^{2+}$ to be a direct indicator of increased mineral weathering and increased alkalinity production (Henriksen, 1979; 1980; Watt et al., 1979). By acidification theory (Watt et al., 1979; U.S. EPA, 1980a, b; 1984; NAPAP, 1984; 1986; 1987a; 1988), alkalinity of Nova Scotian lakes on granite should 
Table 11. Water Chemistry Data $(1955,1977)$ for Nova Scotian Lakes on Granite Bedrock Watersheds.

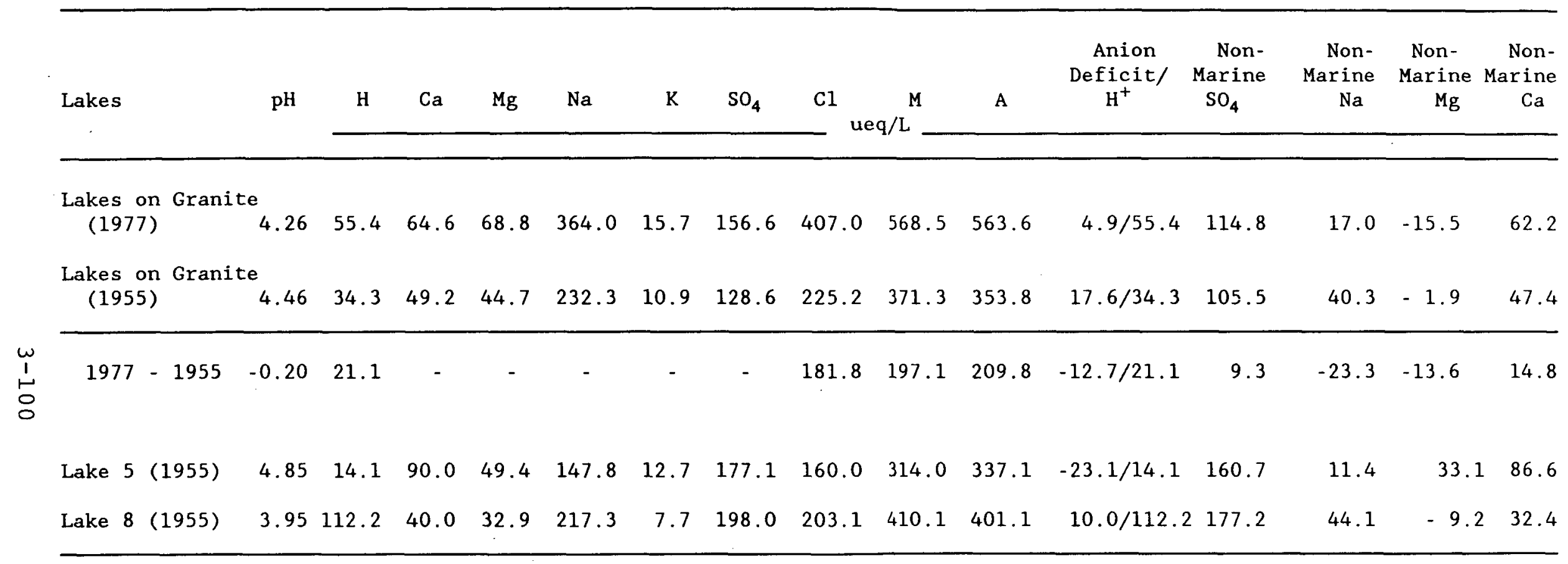

Data from Gorham (1957) and watt et a1. (1979).

All data are in ueq/L except $\mathrm{pH}$.

Data for lakes on granite are mean values for the 7 lakes analyzed and without watershed disturbance between 1955 and 1977

$\mathrm{M}=\mathrm{H}^{+}+\mathrm{Ca}^{2+}+\mathrm{Mg}^{2+}+\mathrm{Na}^{+}+\mathrm{K}^{+}$.

$\mathrm{A}=\mathrm{SO}_{4}^{2+}+\mathrm{Cl}^{*}$

Anion Deficit $=M-A$. 
have increased by $14.8 \mathrm{ueq} / \mathrm{L}$, the amount that the increase in non-marine $\mathrm{Ca}^{2+}$ exceeded the increase in non-marine $\mathrm{SO}_{4}{ }^{2-}$ between 1955 and 1977 (Watt et al. ,1979; Table 11).

Thus, strong acid $\left(\mathrm{H}_{2} \mathrm{SO}_{4}\right)$ titration of alkalinity predicts a slight increase in $\mathrm{pH}$ and alkalinity for these Nova Scotia lakes. But what actually happened was acidification not alkalinization (Table 11). This is exactly opposite of what is expected to have occurred from acidification theory. These Nova Scotian lakes can not have been acidified by acidic deposition as has been asserted (Watt et al., 1979; National Research Council, 1981; Havas et al., 1984).

Lakewater chemistry data (Table 11) show that in 1977, Nova Scotia lake watersheds retained even more $\mathrm{Na}$ and $\mathrm{Mg}, 36.9 \mathrm{ueq} / \mathrm{L}$ more, than they did in 1955. Also, anion deficit decreased by 12.7 ueg/L (from 17.6 ueq/L in 1955 to $4.9 \mathrm{ueg} / \mathrm{L}$ in 1977 , indicating organic acid buffering of these waters that were already highly acidic in 1955 (Table 11). In combination with the nonmarine $\mathrm{SO}_{4}^{2-}$ and $\mathrm{Ca}^{2+}$ data, these data indicate that most of the increased acidity of these waters can probably be attributed to strong acid production by natural watershed processes of ion exchange. Acidification would probably have been even greater in the absence of organic acid buffering.

Watt et al. (1979) recognized that concentration of seasalt in Nova Scotian lakes were considerably higher in 1977 relative to 1955 and noted that storms off the Atlantic Ocean were more prevalent prior to the 1977 sampling than prior to the 1955 sampling. Thus, seasalts being more heavily deposited in precipitation prior to the 1977 can be used to explain the elevated concentrations of the chemical components of seawater in Nova Scotian lakes in 1977 relative to 1955 (Watt et al., 1979). However, Watt et 
al. (1979), being consistent with the theory of acidification, did not consider seasalts to be capable of surface-water acidification (Watt et al., 1979) •

As shown earlier for a number of Norwegian studies, however, seasalt and other neutral salts are capable of acidification of surface waters (Abrahamsen et al., 1978; Rosenqvist, 1978; 1980; Overrein et al., 1980; Skartveit, 1980; 1981; Figure 10; 11; Table 6; 8; 9; 10). Sodium (Na) is the most common cation in seawater. But of the base cations $\left(\mathrm{Ca}^{2+}, \mathrm{Mg}^{2+}, \mathrm{K}^{+}\right.$, and $\left.\mathrm{Na}^{+}\right), \mathrm{Na}^{+}$is often the cation most weakly retained by ion exchange reactions in soil and the least in demand as a nutrient to be taken up by plant ion exchange.

Iag (1968) showed that coastal soils of southern Norway are greatly enriched in exchangeable $\mathrm{Mg}^{2+}$ relative to inland soils but only slightly enriched in respect to $\mathrm{Na}^{+}$(Table 12). This soil chemical gradient is related to the coastal gradient of seasalts in precipitation (Lag, 1968). Thus, marine $\mathrm{Mg}^{2+}$ appears to be a more likely ion-exchange acidifier of nearsurface runoff from highly acidic soils and their associated acidophilic ecosystems than is marine $\mathrm{Na}^{+}$.

Magnesium $\left(\mathrm{Mg}^{2+}\right)$ is plentiful in seawater. The concentration of $\mathrm{Mg}^{2+}$ is about $24 \%$ that of $\mathrm{Na}^{+}$on a charge-equivalent basis. The concentration of $\mathrm{Mg}^{2+}$ in seawater is about $200 \%$ that of $\mathrm{SO}_{4}{ }^{2-}$ on a charge-equivalent basis. The concentration of $\mathrm{SO}_{4}{ }^{2-}$ in seawater is considered to be so significant that marine $\mathrm{SO}_{4}{ }^{2-}$ is subtracted out of coastal freshwaters to estimate nonmarine $\mathrm{SO}_{4}{ }^{2-}$. Thus, concentration of non-marine $\mathrm{SO}_{4}{ }^{2-}$ and all other marinederived ions (including $\mathrm{Nat}$ and $\mathrm{Mg}^{2+}$ ) in coastal freshwaters are subtracted out of overall freshwater chemical composition because the accepted theory of 
Table 12. The Influence of Proximity to the Ocean of Exchangeable Bases in Humus of Southern Norway.

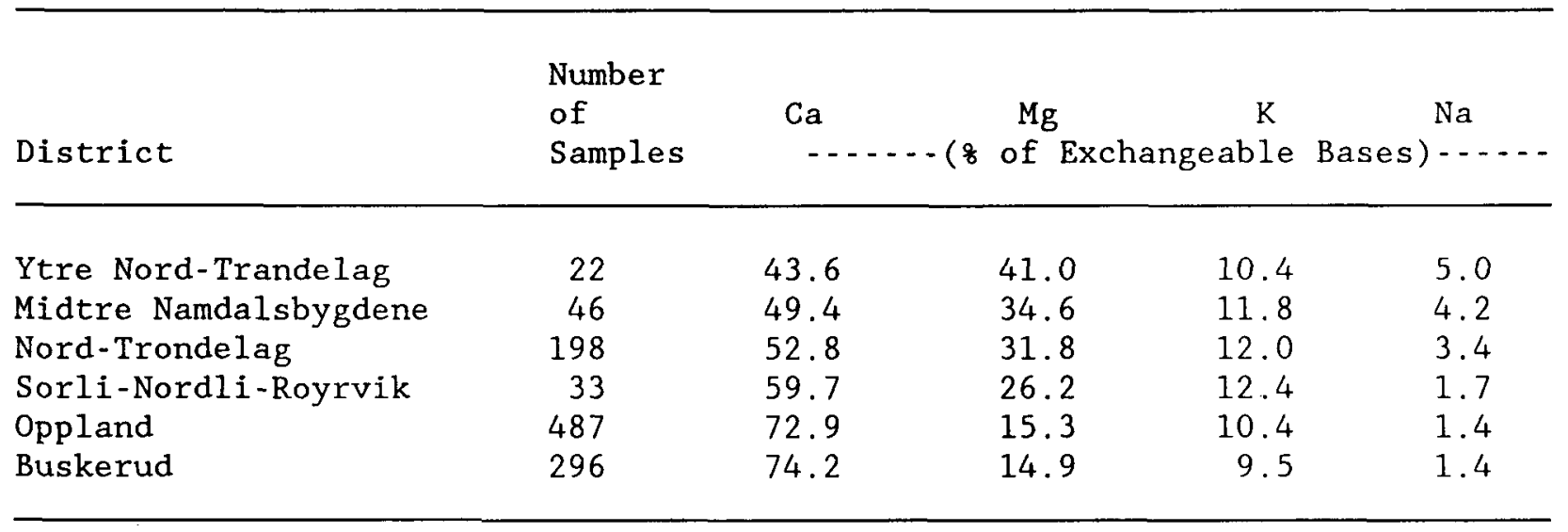

Data from Lag (1968).

Districts arranged in increasing distance from the ocean.

Oppland and Buskerud are considered true inland locations. 
acidification predicts that inputs of neutral salts are incapable of acidifying water. However, we have already seen that there is Norwegian and Canadian data showing otherwise.

Data from the eastern lakes NSWS (Kanciruk et al., 1986) also suggests the possibility of surface-water acidification by strong mineral acids produced by ion exchange of seasalt for some lakes. For example, Reuss (1988) presented data for a NSWS clearwater (DOC $=1.62 \mathrm{mg} \mathrm{C} / \mathrm{L}$ ), acidic (pH =4.50) Cape cod lake, Cahoon Pond, as being a classic example of acidification by deposition of $\mathrm{H}_{2} \mathrm{SO}_{4}$ : clearwater, no anion deficit (actually anion excess), and both the concentrations of non-marine $\mathrm{SO}_{4}{ }^{2-}$ and "acid cations" ( $\mathrm{H}^{+}$and ionic $\mathrm{Al}$ ) equal about $40 \mathrm{ueq} / \mathrm{L}$. Furthermore, the ratio of $\mathrm{Na} / \mathrm{Cl}$ was slightly greater than that of seawater and was claimed to prove that ion exchange for seasalt can not acidify water (Reuss, 1988) as has been earlier hypothesized (Krug et al., 1985).

The data used by Reuss (1988) for Cahoon Pond (Kanciruk et al., 1986) show that concentration of $\mathrm{Mg}^{2+}$ in pondwater is more than $100 \mathrm{ueq} / \mathrm{L}$ less than predicted just from atmospheric deposition of seasalts (Table 13). Thus, soil and plant ion exchange of $\mathrm{H}^{+}$for $\mathrm{Mg}^{2+}$ not only accounts for the approximately $40 \mathrm{ueq} / \mathrm{L}$ of "acid cations", but also accounts for the total elimination of alkalinity that must occur before there can be significant concentrations of "acid cations" in water (Krug, 1988; Table 13).

But the real extent of natural acidification of Cahoon Pond, and other NSWS lakes by soil and plant ion exchange remains unknown because acidic deposition necessarily increases the concentration of base cations to surface waters (F-factor), thereby, making uncertain pre-acidic deposition net strong acid production by ion exchange. Nevertheless, Cape cod surface waters 
Table 13. Some Measured and Predicted Chemical Values for

Cahoon Pond (1D2- 078) - - A NSWS $\mathrm{pH}<5.0$

Clearwater Seepage Pond on Cape Cod.

\begin{tabular}{lrrr}
\hline $\begin{array}{l}\text { Chemical } \\
\text { Parameter }\end{array}$ & Measured & $\begin{array}{c}\text { Marine } \\
\text { (ueq/L) }\end{array}$ & Non-marine \\
\cline { 2 - 3 } $\mathrm{pH} / \mathrm{H}$ & $4.50 / 31.6$ & $35.1^{*}$ & - \\
$\mathrm{Na}$ & 779.1 & 722.2 & 56.9 \\
$\mathrm{Ca}$ & 45.2 & 33.9 & 11.3 \\
$\mathrm{Mg}$ & 73.2 & 175.4 & -102.2 \\
$\mathrm{~K}$ & 14.7 & 15.8 & -1.1 \\
$\mathrm{SO}$ & 128.2 & 86.9 & 41.3 \\
$\mathrm{Cl}$ & 847.1 & 847.1 & 0.0 \\
\hline
\end{tabular}

Data from Kanciruk et al. (1986).

Both closed and equilibrium $\mathrm{pH}=4.50$.

Marine contributions assume that all $\mathrm{Cl}^{-}$is derived from seasalt and marine contributions are in proportion to mean seawater chemistry.

* Marine $\mathrm{H}^{+}=$Non-marine $\mathrm{Na}^{+}+\mathrm{Ca}^{2+}+\mathrm{Mg}^{2+}+\mathrm{K}^{+}$. That the sum of non-marine (watershed) base cations is negative is assumed to represent $\mathrm{H}^{+}$supplied to water by ion exchange of $\mathrm{H}^{+}$for $\mathrm{M}^{2+}$. 
can provide a useful case study with which to determine the relative importance of acidification of surface waters by strong acids from acidic deposition and from ion exchange. The NSWS suggests that cape cod has the highest proportion of highly acidic $(\mathrm{pH}<5.0)$ lakes in the Northeast (Kanciruk et al., 1986).

Cape cod lakes are fed principally by emerging groundwater from highly permeable sands. They receive negligible amounts of near-surface runoff and direct inputs of precipitation are expected to be relatively minor. Many Cape cod lakes and ponds are seepage lakes, as is Cahoon Pond (Mitchell and Soukup, 1981; Dowd, 1984; Kanciruk et al., 1986). Such seepage lakes can be described as big holes that expose the groundwater, i.e., such lakes are literally windows of the regional groundwater table which is tens of feet beneath the land surface. The groundwaters at cape cop are completely neutralized by mineral weathering (Mitchell and Soukup, 1981; Dowd, 1984). The principal effect of acidic deposition on water chemistry of such aged groundwater is to increase the concentration of mineral cations $\left(\mathrm{Ca}^{2+}, \mathrm{Mg}^{2+}\right.$, $\mathrm{K}^{+}, \mathrm{Na}^{+}$) and $\mathrm{SO}_{4}^{2-}$ (N.M. Johnson, 1979; 1982; Johnson et al., 1981; Henriksen, 1982; Jones et al., 1983; NAPAP, 1984; 1987a; Cosby et al., 1985; Gherini et al., 1985; Neal et al., 1986). This increased supply of base cations necessarily results in underestimation of natural acidification of water by ion exchange by current water chemistry data by the extent that deposition results in increased concentrations of basic sulfate to surface waters (e.g., $\mathrm{Ca}^{2+}+\mathrm{Mg}^{2+}+\mathrm{Na}^{+}+\mathrm{K}^{+}+\mathrm{SO}_{4}{ }^{2-}$ ). For example, if $40 \mathrm{ueq} / \mathrm{L}$ of $\mathrm{H}_{2} \mathrm{SO}_{4}$ deposition results in an increase of bases by 20 ueq/L, 20 ueq/L of acidification by ion exchange is masked acidic deposition/watershed interaction. For this hypothetical example, in the absence of acidic 
deposition, ion exchange acidified water $20 \mathrm{ueg} / \mathrm{L}$ more than predicted by current water chemistry. In the case of cape cod Kettle Ponds (which are windows on regional groundwater), apparently all $\mathrm{H}_{2} \mathrm{SO}_{4}$ deposition is neutralized in the aged groundwater that seeps into these lakes and ponds. Unlike the incomplete (75\%) neutralization by mineral weathering of acid in runoff from moss/rock (Rueslatten and Jorgensen, 1978), there appears to be sufficient contact in the very deep gravelly sands of the low relief watersheds of cape cod to completely neutralize acidic deposition, i.e. F-1 (Mitchell and Soukup, 1981; Dowd, 1984).

Thus, cape cod surface waters appear not to be acidified by either acidic deposition or acidic soils. Acidification appears to be by in-lake processes. Apparently, acidification is by sphagnum, and other mosses, that live within these waters (Winkler, 1985; 1988; personal communication). Paleolimnological investigations indicate that these waters have been highly acidic clearwaters for the last 12,000 years (Winkler, 1988; personal communication).

It has been long known that acidophilic ecosystems of the type common in many "sensitive" watersheds of eastern North America and northern Europe have been acidifying the enviromment on the order of the geologic time scale (Clymo, 1963; 1984; Gore, 1983; Andrus, 1986; Carter, 1986). Indeed, the very existence of acidophilic ecosystems (ecosystems that prefer or require highly acidic terrestrial and aquatic habitats) in "sensitive" watersheds present a simple and compelling de facto argument that many of these systems are naturally acidic.

Sphagnum mosses flourish in and create unusually acidic habitats. Sphagnum mosses are the best-known example of acidification of water by plant 
ion exchange (Clymo, 1963; Gore, 1983; Andrus, 1986; Carter, 1986; Malmer, 1986) .

There is a common misconception that sphagnum acidifies water by releasing organic acids. Thus, acidification by sphagnum is asserted to be a

process that produces highly colored waters acidified by weak organic acids. Clymo (1963; 1984) showed, however, that organic acids do not issue from the living plant but may issue from peats underlying the moss.

That oligotrophic (nutrient poor) wetland ecosystems typified by sphagnum reduce total concentration of ions in water is well recognized among wetland ecologists (Gore, 1983; Andrus, 1986; Carter, 1986; Malmer, 1986). Studies done on water moving through, and in intimate contact with oligotrophic wetland vegetation (as opposed to channelized flow somewhat isolated from vegetation) show that reduction in total ionic concentration is associated with increased acidity of water (Gorham and Pearsall, 1956; Pearsall, 1956; Newbould, 1960; Retzsch et al., 1982; Vitt and Bayley, 1984).

Sphagnum and other oligotrophic wetland communities exist where rates of nutrient inputs by water are low, i.e., relatively low flow and low rate of mineral weathering (Gorham and Pearsall, 1956; Pearsall, 1956; Newbould, 1960; Clymo, 1963; 1984; Gore, 1983; Andrus, 1986; Carter, 1986; Malmer, 1986). Thus, the hydrological settings of these naturally-acidifying ecosystems tend to be headwaters in siliceous geologic terrain with relatively low rates of mineral weathering having cool to temperate humid climates.

Thus, acidophilic plant communities can acidify waters in precisely those locations said to be acidified by acid rain. And the nature of such acidification can be precisely that attributed solely to acid rain: 
acidification by strong mineral acids.

Data from a watershed study of an acidic $(\mathrm{pH}<5.0)$ clearwater pond, Enmons Pond, in connecticut is useful in illustrating the influence of plant ion exchange on the creation of highly acidic clearwaters acidified by strong mineral acid. Enmons pond is located in a region receiving relatively high rates of acidic $\left(\mathrm{H}_{2} \mathrm{SO}_{4}\right)$ deposition. And, it is located precisely in that type of landscape believed to be most sensitive to acidification by acidic deposition: a headwater pond in recently-glaciated terrain on granite-like bedrock (Rush et al., 1985). Emmons Pond was one of 229 headwater lakes and streams in New England surveyed by the U.S. Fish and Wildlife Service (Haines and Akielaszak, 1983). Emmons Pond was reported to be a clear-cut case of acidification by acidic $\mathrm{H}_{2} \mathrm{SO}_{4}$ deposition (Haines and Akielaszak, 1983) .

However, research shows that at Emmons Pond, like the Cape cod lakes and ponds (Mitchell and Soukup, 1981; Dowd, 1984), there is essentially complete neutralization of acidic deposition within the watershed because of sufficient contact in the gravelly sands of the low relief watershed (Rush et al., 1985). Enmons pond is fed by emerging pH-6 groundwater. The groundwater is acidified to $\mathrm{pH} \sim 4.3$ as it passes through a sphagnum "lawn" (Table 14). Water chemistry data indicate that acidification is by moss uptake of nutrient cations and replacement with $\mathrm{H}^{+}$rather than by release of organic acids from the moss (Table 14). Concentrations of DOC actually decrease as water passes through sphagmum, from $6.1 \mathrm{mg} / \mathrm{L}$ in shallow groundwater to $2.0 \mathrm{mg} / \mathrm{L}$ after passing through the moss (Table 14). Also, there is an anion deficit of $41.4 \mathrm{ueg} / \mathrm{L}$ in the highly acidic clearwater issuing from the moss (Table 14) which is typical of acidic clearwaters having dissolved ionic metals (Table 4). 
Table 14. Select Mean Water Chemistry Data for the Emmons Watershed, 1983-84.

\begin{tabular}{lcccccccccc}
\hline Sample & $\mathrm{pH}$ & $\begin{array}{c}\mathrm{TOC} \\
(\mathrm{mg} / \mathrm{L})\end{array}$ & $\mathrm{Ca}$ & $\mathrm{Mg}$ & $\mathrm{K}$ & $\begin{array}{c}\mathrm{Na} \\
(\mu \mathrm{eq} / \mathrm{L})\end{array}$ & $\mathrm{Cl}$ & $\mathrm{SO}_{4}$ & ANC \\
\hline
\end{tabular}

$\begin{array}{llllllllll}\text { Shallow groundwater } & 6.07 & 6.1 & 107.3 & 56.3 & 31.3 & 107.7 & 38.5 & 197.4 & 73.5\end{array}$ $\begin{array}{lrllllllll}\text { Outlet Sphagnum } & 4.28 & 2.0 & 23.5 & 31.8 & 7.2 & 61.7 & 50.0 & 168.0 & -46.4\end{array}$ lawn (Hurricane Brook)

Data from Krug (1988). 
Total ionic concentration of water is reduced from 309 to $218 \mathrm{ueq} / \mathrm{L}$ as emerging groundwater is acidified by sphagnum (Table 14). Such decrease in ionic concentration has also been shown in other studies for water passing through similar acidophilic wetland ecosystems (Gorham and Pearsall, 1956; Pearsall, 1956; Newbould, 1960; Retzsch et al., 1982; Vitt and Bayley, 1984). Wetlands occupy only 5\% of the watershed of Emmons Pond (Rush et al., 1985). Nevertheless, the wetlands appear to be the predominant factor influencing water chemistry. While only occupying a very small fraction of the watershed, these wetlands are hydrologically very significant because virtually all water passing through the watershed passes through these wetlands (Rush et al., 1985). Water passing through the wetlands lose mineral bases and gain $\mathrm{H}^{+}$and ionic metals. The wetlands in the Emmons watershed also appear to significantly influence sulfur chemistry by lowering mean concentration of water passing through them (Krug, 1988; Table 14).

The Emmons Pond study illustrates that while $\mathrm{SO}_{4}{ }^{2-}$ is the dominant anion in water issuing from sphagnum, it can not be factually claimed that atmospheric deposition of $\mathrm{H}_{2} \mathrm{SO}_{4}$ is the source of $\mathrm{H}^{+}$. The role of acidic deposition in this case appears to be little more than to increase the total ionic concentration of water and total supply of nutrients to the wetland ecosystem. Without the sphagnum in the wetlands, Emmons Pond would not be an acidic, clearwater pond, it would be a circumneutral, clearwater pond (Krug, 1987; 1988). Contrary to common scientific belief, that the highly acidic clearwater coming out of the sphagnum is $\mathrm{SO}_{4}{ }^{2-}$ dominated does not mean that atmospheric $\mathrm{H}_{2} \mathrm{SO}_{4}$ deposition is the source of $\mathrm{H}^{+}$.

Application of acidification theory to contemporary water chemistry data and watershed input/output budgets miss possible offsetting sources and sinks 
of $\mathrm{SO}_{4}{ }^{2}$ - in watersheds. Therefore, it is uncertain that without direct study of internal watershed sources and sinks of $\mathrm{SO}_{4}{ }^{2-}$ the degree to which the overall flux of $\mathrm{SO}_{4}{ }^{2-}$ responds to increased $\mathrm{SO}_{4}{ }^{2-}$ deposition. Application of acidification theory to contemporary water chemistry data and watershed input/output budgets without objectively-designed and objectively-interpreted watershed studies also miss the uptake of nutrients by sphagnum and the release of $\mathrm{H}^{+}$by sphagnum. Such studies interpreted by the theory of acidification would simply assert, erroneously, that there is insufficient mineral weathering to neutralize inputs of $\mathrm{H}_{2} \mathrm{SO}_{4}$ in Emmons Pond and similar clearwaters.

Thus, certain correlations $\mathrm{(H}^{+}$to $\mathrm{SO}_{4}{ }^{2-}$, insufficient base cations to charge balance inorganic "strong acid" anions) are taken as causal. But correlation does not establish cause no matter how good the correlation.

In summary, Chapter 3.7.1.2, "Alternative Hypotheses of Acidification by Soil and Plant Ion Exchange", has demonstrated that soil and plant ion exchange can strongly acidify water, both on an episodic and sustained basis. Many of the field and laboratory data and observations used to demonstrate natural acidification of surface waters by soil and plant ion exchange are actually data and observations originally used to support the conclusion that such natural acidification is impossible and that the strong acidity of surface waters is necessarily a recent phenomenon due to the recent advent of acidic $\left(\mathrm{H}_{2} \mathrm{SO}_{4}\right)$ deposition.

It is quite clear that considerable evidence exists that invalidates the theory of surface-water acidification.

The real extent of natural acidification of surface waters by soil and plant ion exchange are necessarily understated by application of current 
acidification theory to contemporary water chemistry data. This is because acidic deposition necessarily alters water chemistry. But this alteration of water chemistry is far more complex than $\mathrm{H}_{2} \mathrm{SO}_{4}$ titration of alkalinity and interaction with assumedly steady state, closed mineral landscape systems.

Well known, natural watershed acidification/buffering processes indicate that the theory of acidification has major shortcomings. Nevertheless, very little process-oriented field and laboratory research has been sponsored by acidic deposition programs for studies of these well known watershed processes of acidification/buffering. Accordingly, very little data exists for laboratory and field experiments appropriately designed to assess these acidification/buffering processes in the context of their influence on the assessment of surface-water acidification by acidic deposition.

It is obvious that by not considering all factors that act to buffer against acidification, the damaging effects of acidic deposition on surface waters will be necessarily overestimated. Similarly, by not considering factors (other than acidic deposition) that act to acidify water, the damaging effects of acidic deposition on surface waters will be necessarily overestimated. Thus, ignoring any factor related to acidification, whether that factor acts to buffer or acidify, will necessarily overrepresent, by default reasoning, the role of the only acidifying agent being considered.

Without process-oriented research specifically designed to investigate the effects of acidic deposition/watershed interaction on soils and biology (more comprehensively than that research designed to support acidification theory), we will not be able to adequately evaluate the role of acidic deposition in surface-water acidification. 


\subsubsection{Some Acidification and Buffering Mechanisms of Highly}

Acidic, Organic Rich Landscape Elements

The theory of surface-water acidification assumes that processes necessary and sufficient to scientifically describe acidic deposition/watershed interactions are the interactions of acidic deposition with the processes occurring in deep, well drained mineral soil landscape elements (Henriksen, 1979; 1980; Overrein et al., 1980; Seip, 1980; U.S. EPA, 1980a, b; 1984; Johnson et al., 1981; National Research Council, 1981; NAPAP, 1984; 1986; 1987a; Van Breeman et al., 1984; 1985; Cosby et al., 1985; Reuss et al., 1986; 1987; Henriksen and Brakke, 1988).

Thus, the theory of surface-water acidification may be a reasonably accurate predictive tool for waters whose chemistries are solely controlled by the processes of deep soil, well drained mineral landscapes. Acidification theory is probably adequate for the majority of waters in "highly impacted" regions like southern Norway and the Northeast. Even in these "highly impacted" regions most waters have considerable alkalinities (Wright and Snekvik, 1977; Haines and Akielaszak, 1983; Kanciruk et al., 1986) which indicates that water chemistry is principally that of relatively aged, mineral-rich groundwater.

But, waters of concern tend to be very dilute and mineral poor, having little or no alkalinity. It is counter-intuitive and counter-real-worldobservational to believe that watershed processes of "sensitive" watersheds are principally controlled by the processes of deep, well drained mineral landscapes are weakest. Studies show that most highly acidic surface waters are not controlled by processes of deep, well drained mineral soil landscape elements (Braekke, 1976; Likkens et al., 1977; N.M. Johnson, 1979; Rosenqvist, 1978; 1980; Johnson et al., 1981; Overrein et al., 1980; Seip, 1980; Driscoll 
and Iikens, 1982; Duhaime et al., 1983; Jones et al., 1983; Krug and Frink, 1983a, b; Retzsch et al., 1983; Gherini et al., 1985; Lefohn and Klock, 1985; Rush et al., 1985; Schofield et al., 1985; James and Riha, 1986; KesselTaylor, 1986). It is precisely in such "sensitive" watersheds that any theory of surface-water acidification based on processes of deep, well drained mineral soil landscapes is weakest, subject to greatest error, and is least appropriate. Ironically, this is precisely where the theory of acidification is being applied - to situations where it is least relevant and least applicable.

But, if there is one area of interest where the theory of surface-water acidification may be a reasonably accurate predictive tool, it is for those waters whose chemistries are solely controlled by the processes of deep soil, well drained mineral landscapes. The acidification issue that may be addressable by acidification theory is the potential future acidification of currently non-acidic waters. However, the following discussion suggests that such surface waters are unlikely to become acidified by acidic deposition in the foreseeable future.

Runoff from mineral soils typical of recently-glaciated terrain of the northeastern United States contains negligible amounts of $\mathrm{H}^{+}$(e.g., Likens et al., 1977; N.M. Johnson, 1979; Johnson et al., 1981; Gherini et al., 1985). Numerous experiments show that ion exchange of acid added to mineral soils rapidly results in nearly complete replacement of added $\mathrm{H}^{+}$with base mineral cations $\left(\mathrm{Ca}^{2+}, \mathrm{Mg}^{2+}, \mathrm{Na}^{+}, \mathrm{K}^{+}\right)$, i.e. the $\mathrm{F}$-factor due to ion exchange alone approaches 1.0 (Reuss and Johnson, 1985). Only when base saturation of soil (base saturation is that portion of exchangeable cations that are base mineral cations) is less than $2 \%$ does the ion exchange F-factor go below 0.5 
(Reuss and Johnson, 1985). Base saturations of $2 \%$, or lower, are almost unheard of for even highly acidic Northeast (Prince and Raney, 1961) and Norwegian soils (Lag, 1968; Bergseth, 1977).

Chapters 3.6 and 3.7.1 show that the water chemistry of runoff is controlled by even brief and imperfect contact with soils through cation exchange reactions. Cation exchange reactions in soils are exceedingly rapid, generally being completed in microseconds for physically-unobstructed surfaces; commonly requiring only up to several seconds due to hysteresis for physically-obstructed surfaces (Kelley, 1948; Adamson, 1973; Sposito, 1984). Thus, it is not surprising that $F$ values for even $\mathrm{pH}<5.0$ waters examined so far are greater than 0.5 (Rueslatten and Jorgensen, 1978; Mitchell and Soukup, 1981; Dowd, 1984; Rush et al., 1985; Winkler, 1985; 1988; Krug, 1988; Table 14).

In conclusion, it appears that ion exchange F-Factor, alone, can account for the essential absence of appreciable $\mathrm{H}^{+}$in runoff from mineral soil landscape elements of recently-glaciated terrain.

The question then arises as to whether acidic $\mathrm{H}_{2} \mathrm{SO}_{4}$ deposition will soon deplete the soil's supply of base cations. Is the landscape, particularly granitic landscape of recently-glaciated terrain, capable of replenishing base mineral cations lost to ion exchange with $\mathrm{H}^{+}$?

Simple considerations of geology and mineralogy suggest that runoff from mineral soil landscape elements of recently-glaciated terrain is unlikely to become acidified in the foreseeable future (N.M. Johnson, 1979; 1982; Krug and Frink, 1983a, b). Even granitic watersheds, which are commonly believed to have relatively little bases to resist acidification, have been shown to have enormous acid neutralizing capacity relative to rates of acidic 
deposition (N.M. Johnson, 1979; 1982; Krug and Frink, 1983a, b). For example, the bedrock and soils of the Hubbard Brook Experimental Watershed are considered to be especially poor in bases with which to neutralize acidic deposition (Likens et al., 1977). Nevertheless, just two feet of unweathered Hubbard Brook soil (C horizon) has the capacity to neutralize about 220,000 years of acidic deposition, $\mathrm{pH}=4.3$ at $1 / \mathrm{m}^{\cdot} \mathrm{yr}$ (Krug and Frink, 1983b). It is inconceivable that current levels of fossil fuel consumption can be kept up for 2,200 centuries.

In conclusion, it appears that even granitic, shallow mineral soil landscapes have essentially infinite quantities of base mineral cations relative to inputs of acidic $\mathrm{H}_{2} \mathrm{SO}_{4}$ deposition.

However, the above statements are based on the implicit assumption that watersheds are static, closed systems (except for inputs of acidic deposition and inputs and outputs of atmospheric gases and water). Nevertheless, the very existence of watersheds belie such an assumption. The physical existence of watersheds is due to erosional and depositional processes that create the topography of watersheds which, in turn, influences the flow and direction of flow of water. Assuming rates of erosion of $1 \mathrm{in./100} \mathrm{yr.} \mathrm{and} 1$ in./1,000 yr. means that a new two feet of soil will present itself in 2,400 and 24,000 years, respectively.

In conclusion, it appears that base depletion by acidic deposition can not keep up with erosional/soil-forming processes of granitic terrains of the Northeast. On the long-term average, new supplies of weatherable bases are being exposed faster than acidic deposition can deplete them from the landscape. Waters currently not acidic are not likely to become acidified because of acidic $\mathrm{H}_{2} \mathrm{SO}_{4}$ deposition depleting the acid neutralizing capacity 
of mineral landscape elements of recently-glaciated terrains, such as occur in the northeastern United States.

The questions then arise, if acidic $\mathrm{H}_{2} \mathrm{SO}_{4}$ deposition is largely incapable of acidifying runoff from mineral soils of recently-glaciated terrains 1.)why are currently acidic waters acidic, and 2.) - what role has acidic deposition played in their acidification?

The answers to these questions lies in determining:

1.) - What landscape elements does acidic runoff issue from, and;

2.)- How does acidic deposition interact with landscape elements that supply acidic runoff to surface waters?

The "classic" view of an acidic lake or stream that has been passed on to us from studies in Scandinavia (Braekke, 1976; Overrein et al., 1980; Seip, 1980), Hubbard Brook (Likens et al., 1977; N.M. Johnson, 1979; Johnson et al., 1981; Driscoll and Likens, 1982), and the IIWAS research in the Adirondacks (Gherini et al., 1985; Schofield et al., 1985). All of these studies show that highly acidic surface waters receive disproportionately large amounts of water as near-surface runoff from the highly acidic, organic-rich surficial soil materials and peats that mantle the studied watersheds (Braekke, 1976; Likens et al., 1977; N.M. Johnson, 1979; Johnson et al., 1981; Overrein et al., 1980; Seip, 1980; Driscoll and Likens, 1982; Gherini et al., 1985; Schofield et al., 1985).

There appears to be a true consensus on the nature of "sensitive" watersheds. The advocates of the alternative hypotheses of acidification also report that acidic, near-surface runoff issues from the above mentioned highly acidic, organic rich soil material and/or acidophilic ecosystems (Rosenqvist, 1978; 1980; Duhaime et al., 1983; Jones et al., 1983; Krug and Frink, 1983a, b; Retzsch et al., 1983; Lefohn and Klock, 1985; Rush et al., 
1985; James and Riha, 1986; Kessel-Taylor, 1986).

Accordingly, the acidic deposition/watershed interactions relevant to the issue of aquatic acidification for many sensitive watersheds are not simply the interactions of acidic deposition with mineral bases but also the interactions of acidic deposition with highly acidic, organic-rich soils and peats. In these mantles, organic acids are formed and these acids are the first and primary terrestrial components to interact with acidic deposition (Krug and Frink, 1983a, b). It has been hypothesized that it is inappropriate to attribute the properties and processes of deep, well drained mineral soils to the highly acidic, organic-rich soils and acidophilic ecosystems that mantle many sensitive watersheds of eastern North America and northern Europe from which acidic runoff issues (Krug and Frink, 1983a; Krug et al. ,1985; Krug, 1987; 1988).

In summary, the chemistry of acidic deposition/watershed interaction for many "sensitive" watersheds includes the interaction of acid-with-acid (organic) and not just acid-with-base (mineral) as advocated by the theory of surface-water acidification. It should be expected that the reaction of acid-with-acid can be quite different from the reaction of acid-with-base.

The theory of acidification asserts that highly acidic soils necessarily yield alkaline water and have little capacity to neutralize inputs of acid. Accordingly, only small additions of strong acid to highly acidic soils and peats are asserted to result in large pH depressions because these base-poor, highly acidic materials have few bases with which to offset imputs of acid (Seip, 1980; Johnson et al., 1981; Driscoll and Likens, 1982; Nilsson et al., 1982; Peterson, 1984; U.S. EPA, 1984; NAPAP, 1984; 1986; 1987a; Van Bremmen et al., 1984; 1985; Ad Hoc committee on Acid Rain: Science and Policy, 1985; 
Cosby et al., 1985; Krug, 1985; Reuss et al., 1986; 1987; De Vries and Breeuwsma, 1987).

Nevertheless, numerous laboratory and field data already presented show that highly acidic soils can strongly buffer against $\mathrm{pH}$ depressions from addition of strong acids and can yield highly acidic waters in the absence of inputs of acid (e.g., Tables 6, 8, 10, Figure 10, and other experimental and field results presented in Chapter 3.7.1)

Table 15 shows a soil acidity/vegetation altitudinal relationship for the Smoky Mountains of North Carolina which resembles that of the Adirondack Mountains of New York (Krug and Frink, 1983a, b; Figure 9). Given the relationship of soil leachate $\mathrm{pH}$ to soil $\mathrm{pH}$, and combined with the altitudinal gradient in hydrology, it has been hypothesized that natural soil acidity plays a significant role in the relationship of increasing altitude to increasing water acidity observed in the Adirondacks and elsewhere (Krug and Frink, 1983a; Figure 9).

Table 15 also shows that acidic soils exert a remarkable ability to buffer runoff from acidification by exceptionally high rates of simulated acidic deposition: $\mathrm{pH} 3.2$ simulated precipitation has, relative to simulated unpolluted precipitation, little effect in acidifying runoff from highly acidic soil from the Smoky Mountains (Table 15). Also, the more humified and the more acidic the soil, the more acidic the water derived from that soil. Also, the more acidic and humified the soil, the better it resists change in pH upon even exceptionally high rates of acid addition (Table 15) .

That highly acidic soils yield highly acidic water in the absence of acidic deposition (Table 15), is impossible to reconcile with the theory of acidification. That highly acidic soils also strongly buffer runoff against 
Table 15. The pH of Leachate Generated by Passing Simulated Precipitation Through Soil Horizons From Three Forest Cover Types on the Raven Fork Watershed.

\begin{tabular}{|c|c|c|c|c|}
\hline \multirow{2}{*}{$\begin{array}{c}\text { Forest Cover } \\
\text { Type }\end{array}$} & \multirow{2}{*}{$\begin{array}{l}\text { Soil } \\
\text { Horizon }\end{array}$} & \multicolumn{3}{|c|}{ "Precipitation" $\mathrm{pH}$} \\
\hline & & 5.7 & 4.1 & 3.2 \\
\hline & & \multicolumn{3}{|c|}{ Leachate $\mathrm{pH}$} \\
\hline Northern & $\mathrm{Oe}$ & 4.8 & 4.8 & 4.6 \\
\hline Hardwood & $\mathrm{Oe}+\mathrm{Al}$ & 4.2 & 4.1 & 4.1 \\
\hline Red Spruce- & $0 i$ & 4.6 & 4.6 & 4.4 \\
\hline \multirow{2}{*}{ Yellow Birch } & $\mathrm{Oi}+\mathrm{Oa}$ & 3.9 & 3.8 & 3.6 \\
\hline & $\mathrm{Oi}+\mathrm{Oa}+\mathrm{Al}$ & 3.8 & 3.8 & 3.7 \\
\hline Red Spruce- & Oi & 4.0 & 3.9 & 3.6 \\
\hline \multirow[t]{2}{*}{ Frazier Fir } & $\mathrm{Oi}+\mathrm{Oa}$ & 3.6 & 3.5 & 3.4 \\
\hline & $\mathrm{O} \mathbf{i}+\mathrm{Oa}+\mathrm{A}$ & 3.5 & 3.5 & 3.4 \\
\hline
\end{tabular}

Data from Jones et al. (1983).

$0 i$ = partially decomposed litter, little humified.

$\mathrm{Oa}=$ moderately decomposed litter, moderately humified.

$\mathrm{Oa}=$ well decomposed humus, well humified.

$\mathrm{A}$ and $\mathrm{Al}=$ mineral soil enriched with humic acids. 
acidification (Table 15) is, likewise, impossible to reconcile with the theory of acidification.

In summary, Table 15 (as well as data earlier presented in Tables 6, 8, 10, Figure 10, and other experimental and field results presented in Chapter 3.7.1) illustrate that highly acidic soils strongly buffer against change in $\mathrm{pH}$ upon addition of strong acid. These data also show that such highly acidic soil materials yield highly acidic runoff in the absence of acidic deposition.

By ignoring processes that act to acidify and/or buffer water in landscape elements that supply acidic runoff to currently-acidic surface waters the theory of surface-water acidification necessarily overstates the role of acidic deposition in acidification of surface waters.

Thus, the theory of acidification does not accurately predict acidic deposition/watershed interactions for landscape elements that supply acidic runoff to many currently acidic surface waters. These data suggest an alternative hypothesis that many currently acidic surface waters were naturally acidic prior to the advent of man-made acidic deposition and that the effects of acidic deposition are superimposed upon natural processes that strongly acidify and buffer water (Krug and Frink, 1983a, b).

The following chapters discuss four processes of organic acidification/buffering generally ignored by acidification theory but which can help explain the data already presented and additional data concerning the water chemistry of "sensitive" watersheds:

1. - weak acid buffering by humic substances;

2. - pH-dependent solubility of terrestrial humic substances;

3. - flocculation of humic substances from solution; and 
4. - strong acid production by weak acids in soils. 


\subsubsection{Weak Acid Acidification/Buffering By Humic Substances}

There are both similarities and differences in the properties and behavior of bicarbonate and humic solutions. Both bicarbonate and humic solutions of weak organic acids buffer against changes in $\mathrm{pH}$ associated with the addition of strong mineral acid, such as $\mathrm{H}_{2} \mathrm{SO}_{4}$ (Figure $12 ; 13$ ). Not much change in water $\mathrm{pH}$ should be expected until most of the humate ( $\mathrm{RCOO}^{-}$) is consumed by titration with $\mathrm{H}_{2} \mathrm{SO}_{4}$ (Krug, 1987; Figure 13), much as little change in $\mathrm{pH}$ should be expected for bicarbonate solutions until most of the bicarbonate $\left(\mathrm{HCO}_{3}{ }^{-}\right.$) is consumed by titration with $\mathrm{H}_{2} \mathrm{SO}_{4}$ (Figure 12). One important difference between the two surface-water solutions is that humic solutions can be buffered at $\mathrm{pH}$ values considerably more acidic than is possible by carbonate solutions. Such buffering of acidic waters is indicated in Henriksen's predictive nomograph for waters in southern Norway (Chapter, 3.5; Figure 8). And, NSWS data for eastern U.S. lakes (Kanciruk et al., 1986) show that humic acids acidify surface waters to $\mathrm{pH}$ values as acidic as $\mathrm{pH} 3.8$ (Reuss, 1988; Krug, 1988).

Weak acid acidification/buffering of both carbonate and humate solutions is considered by some scientists in regard to aquatic acidification (e.g., Krug and Frink, 1983a, b; oliver et al., 1983; Gherini et al., 1985) but not by most who consider waters to be naturally inorganic solutions produced by carbonic acid weathering of minerals (Henriksen, 1979; 1980; Overrein et al., 1980; Seip, 1980; U.S. EPA, 1980a, b; 1984; Johnson et al., 1981; National Research Council, 1981; NAPAP, 1984; 1986; 1987a; Van Breeman et al., 1984; 1985; Cosby et al., 1985; Reuss et al., 1986; 1987; Henriksen and Brakke, 1988). Furthermore, weak acid acidification/buffering of water by humic 

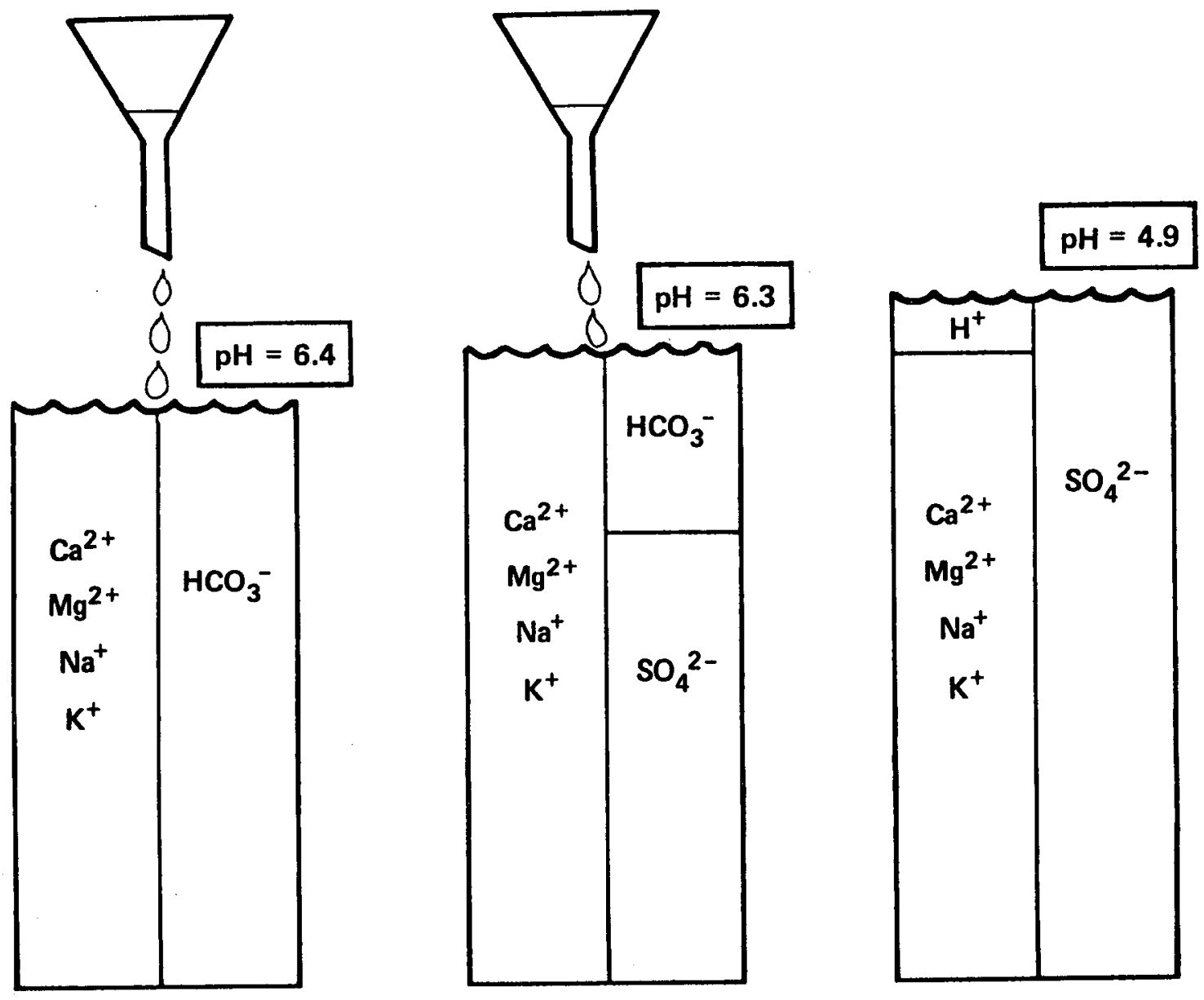

Figure 12. Titration of a bicarbonate solution of mineral bases. Little change in $\mathrm{pH}$ is observed until most bicarbonate is consumed by titration with sulfuric acid. 

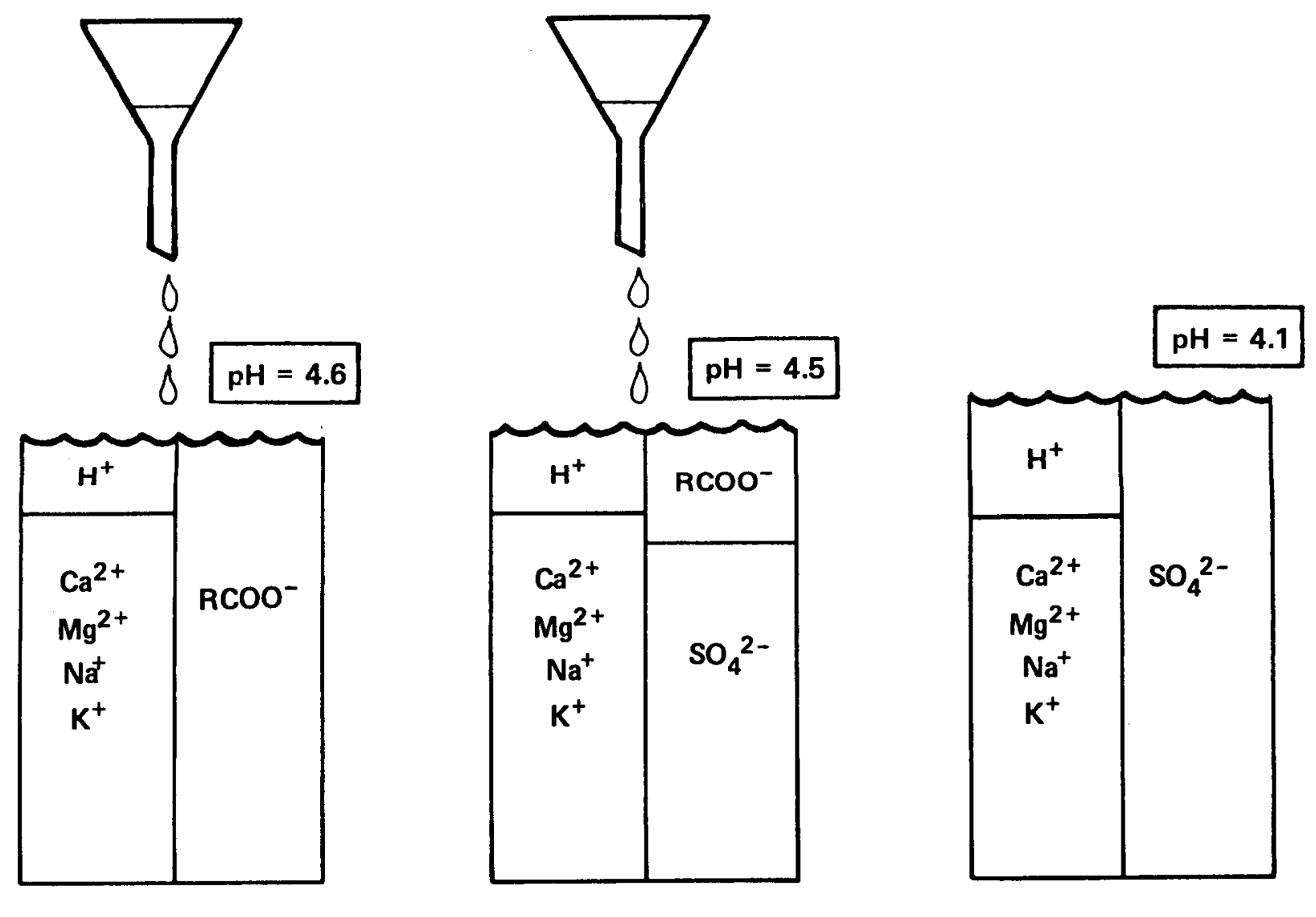

Figure 13. Titration of a humic acid solution by sulfuric acid. Iike the bicarbonate solution, the humic solution buffers against $\mathrm{pH}$ change by addition of strong acid. The humic solution is buffered at a range of $\mathrm{pH}$ values considerably more acidic than is possible by carbonate solutions open to the atmosphere. 
acids does not appear to be incorporated into acidification theory used by NAPAP (U.S. EPA, 1984; NAPAP, 1984; 1986; 1987a; 1988; Cosby et al., 1985; Reuss et al., 1986; 1987; Henriksen and Brakke, 1988).

While researchers believe that present-day concentrations of $\mathrm{HCO}_{3}{ }^{-}$do not represent pre-acid rain levels, they often do not consider that present-day concentrations of $\mathrm{RCO}^{-}$do not represent pre-acid rain levels. Besides examples already presented in Chapter 3.5, 3.6, and 3.7.1, interpretation of Regional IIWAS (RIIWAS) data by Driscoll and Newton (1985; Table 16) further illustrate this problem.

Barmes and Iittle Echo are seepage ponds in the Adirondack Mountains of New York, as are many of the highly acidic, base-poor waters of the lake district of coastal Australia which do not receive highly polluted man-made acidic deposition (Table 16; Chapter 3.9). The chemistry of seepage ponds is believed to be principally influenced by the chemistry of precipitation, especially if these waters are very dilute (contain few base mineral cations). Actually, all that can be said from the fact that waters are very dilute is that the water chemistry of such seepage ponds are little influenced base-rich groundwater. Seepage ponds like Barnes and Iittle Echo, and those in coastal Australia, receive most of their water from the surrounding watershed but the concentrations of the products of mineral weathering in their waters are very low. It seems that if surface waters are not chemically indicative of aged, mineral-rich groundwaters, they are automatically and incorrectly assumed, by default reasoning, to be influenced principally by atmospheric deposition (U.S. EPA, 1984; Driscoll and Newton, 1985) •

Because sulfate is the principal anion in these acidic seepage ponds and 
Table 16. Comparison of Some Highly Acidic Adirondack and Australian Waters.

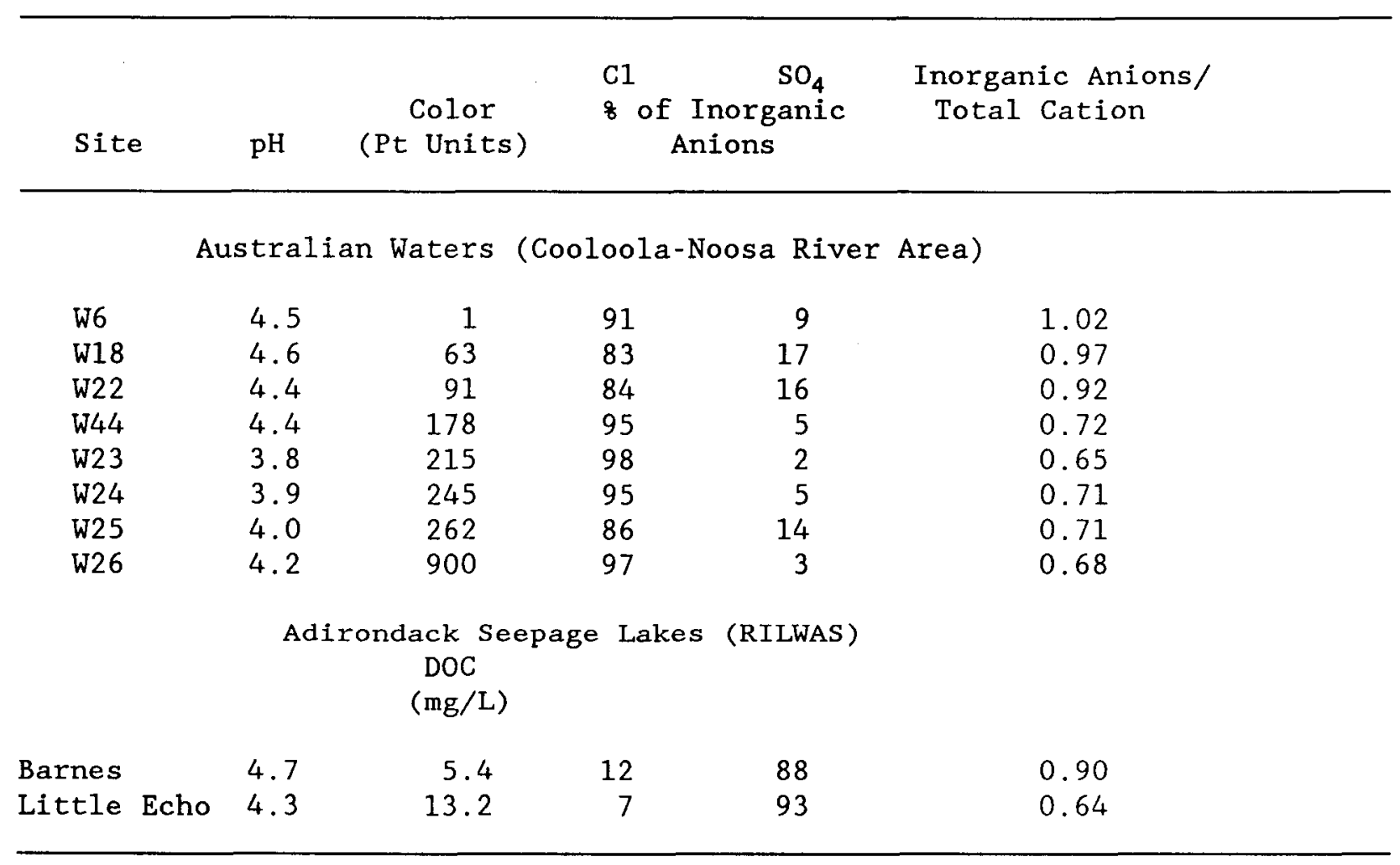

Inorganic Anions $=\mathrm{Cl}^{-}+\mathrm{SO}_{4}{ }^{2-}+\mathrm{NO}_{3}{ }^{-}$

Total Cations $=\mathrm{H}^{+}+\mathrm{Ca}^{2+}+\mathrm{Mg}^{2+}+\mathrm{K}^{+}+\mathrm{Na}^{+}+\mathrm{NH}_{4}^{+}$for Australian data.

Total Cations $=\mathrm{H}^{+}+\mathrm{Ca}^{2+}+\mathrm{Mg}^{2+}+\mathrm{K}^{+}+\mathrm{Na}^{+}+\mathrm{NH}_{4}^{+}+\mathrm{Al}^{2+}$ for Adirondack data. Australian data from Reeve et al. (1985).

Adirondack data estimated from Driscoll and Newton (1985). 
anion deficits are only about $10 \%$ and $36 \%$ for Barnes and Little Echo, respectively (Table 16), these ponds are stated to be acidified principally by deposition of $\mathrm{H}_{2} \mathrm{SO}_{4}$ (Driscoll and Newton, 1985). Such a conclusion is consistent with the theory of surface-water acidification; the titration of humic acids by acidic $\mathrm{H}_{2} \mathrm{SO}_{4}$ was not considered (Driscoll and Newton, 1985) .

However, consideration of $\mathrm{H}_{2} \mathrm{SO}_{4}$ titration of humic acids suggests that humic acids may have been an important acidifying agent for Barmes and Little Echo ponds in pre-deposition times. A value of $10 \mathrm{ueg} / \mathrm{L}$ reactive capacity per mg DOC/L of aquatic humic acid is considered to be a representative value for aquatic humic acids that have not been titrated by other acids (Oliver et al., 1983; Jones et al., 1986). Assuming that pre-deposition concentrations of humic acids were the same as current concentrations (assuming that acidic deposition has not reduced concentrations of aquatic humic acids), the reactive capacity of DOC in Barnes and Little Echo are estimated to have been $67 \%$ and $100 \%$ of their respective total ionic concentrations in pre-deposition times. Thus, when the interaction of acidic deposition with $\mathrm{RCOO}^{-}$is considered, using the same chemical considerations that is used for the interaction of acidic deposition with $\mathrm{HCO}_{3}{ }^{-}$, we find that Barnes and Little Echo ponds probably were not originally $\mathrm{HCO}_{3}^{-}$solutions of mineral bases. They were probably acidic humic waters before the advent of acidic deposition.

By being consistent with weak and strong acid/base chemistry, we see that Barnes and Iittle Echo were probably $\left(\mathrm{H}^{+}+\mathrm{Ca}^{2+}\right)+\mathrm{RCOO}^{-}$waters that were transformed to $\left(\mathrm{H}^{+}+\mathrm{Ca}^{2+}\right)+\mathrm{SO}_{4}{ }^{2-}$-dominated waters by titration with $\mathrm{H}_{2} \mathrm{SO}_{4}$ (Figure 13). The transformation of acidic humic waters to acidic sulfuric waters (Figure 13) is analogous to the transformation of $\mathrm{Ca}^{2+}+\mathrm{HCO}_{3}{ }^{-}$ 
-dominated waters to $\mathrm{Ca}^{2+}+\mathrm{SO}_{4}^{2-}$-dominated waters by titration with $\mathrm{H}_{2} \mathrm{SO}_{4}$ (Figure 12).

Not considering that deposition of strong acids also acts to titrate aqueous humic acids, thereby diminishing the concentration of $\mathrm{RCOO}^{-}$, necessarily results in underestimation of the influence of current concentrations of aqueous humic acids on the acidity/buffering of water chemistry. Such a conclusion is further supported by paleolimnological study of Little Echo Pond, current pH=4.3 (Table 16), which shows that it has experienced no measurable change in $\mathrm{pH}$ since pre-industrial times (Norton and Charles, 1986). Paleolimnological data and principals of weak and strong acid/base chemistry do not support the conclusion necessarily derived from acidification theory that Barnes and Little Echo were $\mathrm{Ca}^{2+}+\mathrm{HCO}_{3}^{-}$waters that had been transformed to $\left(\mathrm{H}^{+}+\mathrm{Ca}^{2+}\right)+\mathrm{SO}_{4}{ }^{2-}$ by acidic $\mathrm{H}_{2} \mathrm{SO}_{4}$ deposition.

The essentially universal use of non-marine $\mathrm{SO}_{4}{ }^{2-}$ in surface waters as a quantitative surrogate for atmospheric $\mathrm{H}_{2} \mathrm{SO}_{4}$ deposition highlights a fundamental inconsistency within the aquatic effects literature on the use of anion to indicate source of cation. No one in the aquatic effects literature claims that appreciable concentrations of non-marine $\mathrm{SO}_{4}{ }^{2-}$ in surface waters indicates that the $\mathrm{Ca}^{2+}$ in surface waters comes from atmospheric deposition of $\mathrm{CaSO}_{4}$. It is commonly believed that $\mathrm{Ca}^{2+}$ was originally associated with $\mathrm{HCO}_{3}{ }^{-}$and some of the $\mathrm{HCO}_{3}^{-}$has been subsequently titrated with and replaced by $\mathrm{SO}_{4}{ }^{2-}$. However, with $\mathrm{H}^{+}$, the presence of appreciable non-marine $\mathrm{SO}_{4}{ }^{2-}$ is almost invariably considered proof that the source of $\mathrm{H}^{+}$in surface waters is from the atmospheric deposition of $\mathrm{H}_{2} \mathrm{SO}_{4}$. Few scientists appear to recognize that currently acidic waters may have been previously acidic having $\mathrm{H}^{+}$ associated with RCOO', some of which has been subsequently titrated with and 
replaced by $\mathrm{SO}_{4}^{2-}$. But if anion indicated source of $\mathrm{H}^{+}$, or any cation, then one would have to conclude from Table 16 that the highly acidic and base-poor waters of coastal Australia, many of which are seepage waters (Bayley, 1964; Bayley et al., 1975; Reeve et al., 1985), suffer from a severe $\mathrm{HCl}$ acid rain problem. This is simply untrue. Apparently, inputs of seasalt are leaching $\mathrm{H}^{+}$out of the runoff through the highly acidic podzol soils and peats in their watersheds (Reeve and Fergus, 1983; Reeve et al., 1985). Acidification theory needs to consider that, not only can groundwater and precipitation influence the chemistry of surface waters, but near-surface runoff through acidic soils and/or acidophilic ecosystems can also autonomously influence the chemistry of surface waters.

In summary, consistent and scientific application of weak and strong acid/base chemistry and field data all indicate that even an accurate estimate of increase in non-marine $\mathrm{SO}_{4}{ }^{2-}$ is not a scientifically-sound quantitative surrogate for acidification of surface waters by acidic $\mathrm{H}_{2} \mathrm{SO}_{4}$ deposition. These data and chemical principals show that the use of nonmarine $\mathrm{SO}_{4}{ }^{2-}$ as a quantitative surrogate for acidification necessarily overstates the role of acidic $\mathrm{H}_{2} \mathrm{SO}_{4}$ deposition in acidification of surface waters. Current acidification theory necessarily overstates the role of acidic $\mathrm{H}_{2} \mathrm{SO}_{4}$ deposition by not adequately considering the role of aquatic humic acids in acidifying and buffering surface waters.

The next Chapters suggest that the error in overestimation may be even larger because pre-deposition concentrations of humic acids may have been even larger than they are today. 
3.7.2.2 pH-Dependent Solubility of Terrestrial Humic Substances

Many "sensitive" watersheds of eastern North America and northern Europe are mantled by highly acidic, organic-rich soil materials and peats. Furthermore, acidic surface waters generally receive mostly near-surface runoff from their highly acidic, organic-rich watershed mantles. Thus, highly acidic organic (humic) material is not only the first terrestrial component that acidic deposition interacts with, but it is also the principal terrestrial component that controls acidic deposition/watershed interaction of many currently acidic surface waters (Braekke, 1976; Rosenqvist, 1978; 1980; Johnson et al., 1981; Overrein et al., 1980; Seip, 1980; Driscoll and Likens, 1982; Duhaime et al., 1983; Jones et al., 1983; Krug and Frink, 1983a, b; Retzsch et al., 1983; Gherini et al., 1985; Lefohn and Klock, 1985; Rush et al., 1985; Schofield et al., 1985; James and Riha, 1986).

Based on considerations of hydrologic flowpath and the nature of watershed materials which interact with runoff to currently highly acidic surface waters, an hypothesis was advanced that most currently highly acidic surface waters were not bicarbonate solutions of mineral bases in pre-deposition times (Krug and Frink, 1983a, b). It was hypothesized that most currently highly acidic surface waters in the Northeast were highly acidic in predeposition times and that the principal influence of acidic $\mathrm{H}_{2} \mathrm{SO}_{4}$ deposition was the qualitative change in the nature of acidity rather than the transformation of surface waters with alkalinity $\left(\mathrm{HCO}_{3}{ }^{-}\right)$into surface waters with acidity $\left(\mathrm{H}^{+}\right)$. It was claimed that the principal effect of acidic deposition falling on many "sensitive" watersheds was to decrease the concentration of humic acids in near-surface runoff with little or no 
measurable change in runoff $\mathrm{pH}$ because of the pH-dependent solubility of terrestrial humic substances (Krug and Frink, 1983a, b). Thus, many waters now acidified principally by $\mathrm{H}_{2} \mathrm{SO}_{4}$, and having what are considered "negligible" concentrations of organic acids, may have been originally highly acidic and humic-rich in pre-deposition times (Krug and Frink, 1983a, b).

This hypothesis based on the pH-dependent solubility of terrestrial humic substances has profound consequences regarding the perceived aquatic effects of acidic deposition. The organic-acid buffering hypothesis of $\mathrm{Krug}$ and Frink (1983a, b) predicts that current acidification theory grossly overstates the magnitude and extent of surface-water acidification by acidic deposition. For example, current acidification theory would assume that a surface water having a pre-deposition value of $60 \mathrm{ueg} / \mathrm{L}$ of non-marine, base mineral cations, which is about the current value for Little Echo Pond (Driscoll and Newton, 1985), would have a pre-deposition pH of about 7.1 produced by carbonic acid weathering of minerals ${ }^{1}$. Thus, such a surface water with a current $\mathrm{pH}$ value of about 4.3 , which is the about the current

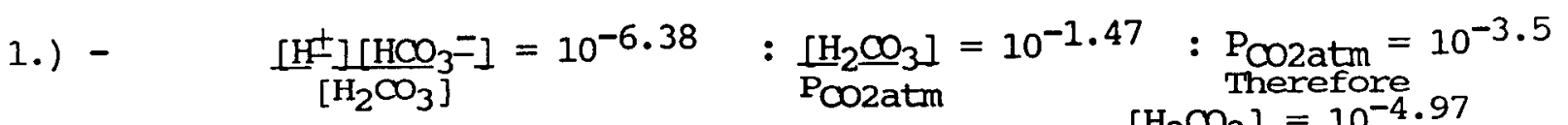

$$
\begin{aligned}
& {\left[\mathrm{H}^{+}\right]\left[\mathrm{HCO}_{3}^{-}\right]=10^{-6.38} \times 10^{-4.97} \text {, or }} \\
& \mathrm{pH}+\mathrm{pHCO}_{3}^{-}=6.38+4.97 \text { : assume base cations }(\mathrm{BC})=\mathrm{HCO}_{3}^{-} \\
& \text {Therefore } 60 \text { ueq } \mathrm{BC} / \mathrm{L}=60 \text { ueq } \mathrm{HCO}_{3}-/ \mathrm{L} \\
& 60 \mathrm{ueq} / \mathrm{L} \text { of } \mathrm{HCO}_{3}^{-}=60 \times 10^{-6} \text {, or } \\
& \mathrm{p}\left(20 \times 10^{-6}\right)=4.22 \\
& \mathrm{pH}+4.22=6.38+4.97 \text {, or } \\
& \mathrm{pH}=6.38+4.97-4.22 \text {, or } \\
& \mathrm{pH} \quad=7.13
\end{aligned}
$$


mean pH value for Little Echo Pond (Driscoll and Newton, 1985; Table 16), would be predicted to have been principally acidified from pH 7.1 to 4.3 by acidic deposition (acidified nearly $3 \mathrm{pH}$ units by acidic deposition) - But the organic-acid buffering hypothesis of Krug and Frink (1983a, b) predicts that Little Echo Pond was probably highly acidic in pre-industrial times and that the principal effect of acidic deposition on Little Echo Pond was to transform it from a highly acidic humic water to a highly acidic, largely $\mathrm{SO}_{4}{ }^{2-}$ water with little or no measurable change in $\mathrm{pH}$. The predicted result of the organic-acid buffering hypothesis (little or no measurable change in $\mathrm{pH}$ ) is quite different from that predicted by current acidification theory (a nearly $3 \mathrm{pH}$ unit change in $\mathrm{pH}$ ) using carbonate chemistry and assuming no change in the F-factor.

Paleolimnology supports the organic-acid-buffering hypothesis for Little Echo Pond in the Adirondack Mountains of New York, showing that no measurable change in $\mathrm{pH}$ (within the resolution of the paleolimnological method, $\pm 0.3 \mathrm{pH}$ units) has occurred for Little Echo Pond over the last several hundred years (Charles and Norton, 1986).

The organic-acid buffering hypothesis of acidic deposition/watershed interaction considers the interaction of acid-with-organic-acids and not just acid-with-mineral-bases in "sensitive" watersheds. It should be expected that the reaction of acid-with-acid can be quite different from the reaction of acid-with-base. Likewise, it is expected that the conclusions derived from considering only acid-to-mineral-bases deposition/watershed interactions can be significantly different from conclusions that also consider acid-toorganic-acids deposition/watershed interactions.

Nevertheless, as is also the case with the comparison of strong acid 
titration of $\mathrm{HCO}_{3}{ }^{-}$versus $\mathrm{RCOO}^{-}$discussed in Chapter 3.7.2.1, the heart of the organic-acid-buffering hypothesis is just the consistent application of chemical principles already used in acidification theory for describing the interaction of acid-with-mineral-bases and applied to the material that acidic deposition is interacting with in the watersheds of many "acidified" surface waters, i.e., acidic deposition is interacting largely with highly acidic, organic materials. The same chemical principles dictating that inputs of $\mathrm{H}_{2} \mathrm{SO}_{4}$ will increase dissolution and loss of mineral bases from watersheds also dictate that inputs of sulfuric acid will decrease the dissolution and export of humic acids from the watershed. These solubility effects are described by well known and fundamental chemical principles and laws, e.g., the Law of Mass Action, Le Chatelier's Principle, and the Common Ion Effect ${ }^{1}$.

The unity of underlying fundamental principles allows the use of pre-

1.) - Highly acidic soil humus and peat are principally composed of molecules of humic acids that are held together in a solid or gel state by hydrogen bonding between $\mathrm{H}$ and $\mathrm{O}$ of acidic functional groups (e.g., $\mathrm{RCOOH}$ ) of the organic acids themselves (Krug and Frink, 1983a; Krug et al., 1985). Thus any process that influences the proportion of $\mathrm{H}^{+}$that remains on the acidic functional groups of humic acids influences the proportion of humic acids that themselves dissociate and separate from acid humus and peat to go into solution. The concentration of $\mathrm{H}^{\mathrm{F}}$ in water influences the degree that $\mathrm{RCOOH}$ dissociates ( $\mathrm{ROOOH}=\mathrm{RCOO}^{-}+\mathrm{H}^{+}$) and, thereby, the proportion of RCOO- itself that dissociates to enter solution from acid humus and peat. Accordingly, humic acids have a pH-dependent solubility that is described by a number of well known chemical principles and laws, e.g., the Law of Mass Action, Le Chatelier's Principle, and the common Ion Effect. The pH-dependent solubility of humic acids is illustrated by what soil chemists do in order to study the chemistry of humic acids. To get humic acids into solution, soil chemists add base to highly acidic peat or soil humus, commonly pH 10 sodium hydroxide $(\mathrm{NaOH})$. This dissolves most of the humus or peat. They do not use $\mathrm{pH} 5.6$ water to dissolve these solid-phase organic acids because only a small fraction of the acids dissolve: albeit the solutions produced by treatment with $\mathrm{pH} 5.6$ water will be highly colored and acidic. It is expected that if even more acidic water is passed through these materials (e.g., pH 4.0 acid rain), an even smaller proportion of the humic acids dissolve. 
existing concepts and terminology to explain the interaction of acidic deposition with the pH-dependent solubility of terrestrial humic substances.

The term and concept of F-factor, already in the aquatic effects literature (e.g., Henriksen and Brakke, 1988), which I will define here as $\mathrm{F}_{\text {mineral }}$, is a quantitative estimate of the proportion $\mathrm{H}^{+}$of added $\mathrm{H}_{2} \mathrm{SO}_{4}$ which is consumed by dissolution of base mineral cations and transmitted to the receiving water as basic sulfate:

$$
\begin{aligned}
\mathrm{F}_{\text {mineral }} & \left.=\frac{\left[\mathrm{Ca}^{*}\right.}{*}+\mathrm{Mg}^{*}+\mathrm{K}^{*}+\mathrm{Na}^{*}\right]::^{*} \\
{\left[\mathrm{SO}_{4}^{*}\right] } & =\text { estimated increase by deposition. } \\
{[\mathrm{j}} & =\text { concentration. }
\end{aligned}
$$

Thus, the proportion of deposited $\mathrm{H}_{2} \mathrm{SO}_{4}$ which goes to increase $\mathrm{H}^{+}$in receiving waters of watersheds as predicted by $F_{\text {mineral }}$ is:

$$
\begin{aligned}
& \mathrm{H}^{+}{ }_{\mathrm{H} 2 \mathrm{SO} 4}=\left[\mathrm{SO}_{4}^{*}\right]-\left[\mathrm{Ca} *+\mathrm{Mg}^{*}+\mathrm{K}^{*}+\mathrm{Na}^{*}\right] \text {, or } \\
& \mathrm{H}^{+}{ }_{\mathrm{H} 2 \mathrm{SO} 4}=1-\frac{\left[\mathrm{Ca}^{*}+\mathrm{Mg}^{*}+\mathrm{K}^{*}+\mathrm{Na}^{*}\right]}{\left[\mathrm{SO}_{4}^{*}\right]} \text {, or } \\
& \mathrm{H}_{\mathrm{H} 2 \mathrm{SO} 4}^{+}=\left(1-\mathrm{F}_{\text {mineral }}\right) \times\left(\left[\mathrm{SO}_{4}^{*}\right]\right)
\end{aligned}
$$

For example, if $\mathrm{F}_{\text {mineral }}$ is 0.5 then $\mathrm{H}_{\mathrm{H} 2 \mathrm{SO} 4}^{+}=(1-0.5) \times\left(\left[\mathrm{SO}_{4} *\right]\right)$, or $\mathrm{H}_{\mathrm{H} 2 \mathrm{SO} 4}^{+}=0.5\left[\mathrm{SO}_{4}{ }^{*}\right]$. This means that, by considerations of $\mathrm{F}_{\text {mineral, }}$ it is estimated that $50 \%$ of $\mathrm{H}^{+}$in deposited $\mathrm{H}_{2} \mathrm{SO}_{4}$ is transmitted to the receiving water if $\mathrm{F}_{\text {mineral }}=0.5$, i.e., acidic $\mathrm{H}_{2} \mathrm{SO}_{4}$ deposition has increased the concentration of $\mathrm{H}^{+}$in the receiving water by about $50 \%$ of its estimated increase in concentration of $\mathrm{SO}_{4}{ }^{2-}$.

I now propose a new F-factor, Forganic, as a term to express the quantitative estimate of the predicted (or measured) decrease in dissolution and concentration of humic acids in solution induced by addition of strong acids, such as $\mathrm{H}_{2} \mathrm{SO}_{4}$ :

$$
\begin{aligned}
& \mathrm{F}_{\text {organic }}=\frac{\left[\mathrm{RCOOH}^{* *}\right]}{\left[\mathrm{SO}_{4}{ }^{*}\right]} \quad \begin{aligned}
: * * & =\text { estimated decrease by deposition } \\
* & =\text { estimated increase by deposition. }
\end{aligned} \\
& \text { [ ] = concentration. }
\end{aligned}
$$


Thus, the proportion of deposited $\mathrm{H}_{2} \mathrm{SO}_{4}$ which goes to increase $\mathrm{H}^{+}$in receiving waters of watersheds by considerations of only Forganic is:

$$
\begin{aligned}
& \mathrm{H}^{+} \mathrm{H} 2 \mathrm{SO} 4=\left[\mathrm{SO}_{4} *\right]-\left[\mathrm{RCOO}^{-* *}\right] \text {, or } \\
& \left.\mathrm{H}_{\mathrm{H} 2 \mathrm{SO} 4}^{+}=1-\frac{\left[\mathrm{RCOO}^{-}\right.}{\left[\mathrm{SO}_{4}^{*}\right]}\right] \text {, or } \\
& \mathrm{H}_{\mathrm{H} 2 \mathrm{SO} 4}^{+}=\left(1-\mathrm{F}_{\text {organic }}\right) \times\left(\left[\mathrm{SO}_{4}{ }^{*}\right]\right)
\end{aligned}
$$

For example, if $\mathrm{F}_{\text {organic }}$ is 0.5 then $\mathrm{H}^{+} \mathrm{H} 2 \mathrm{SO} 4=(1-0.5) \mathrm{X}\left(\left[\mathrm{SO}_{4} *\right]\right)$, or $\mathrm{H}^{+}{ }_{\mathrm{H} 2 \mathrm{SO} 4}=0.5\left[\mathrm{SO}_{4} *\right]$. This means that, by considerations of $\mathrm{F}_{\text {organic only, }}$ acidic $\mathrm{H}_{2} \mathrm{SO}_{4}$ deposition is estimated to have increased the concentration of $\mathrm{H}^{+}$in the receiving water by about $50 \%$ of its estimated increase in concentration of $\mathrm{SO}_{4}{ }^{2-}$.

In one sense, the result of reaction of acid-with-acid is quite different to the reaction of acid-with-base. In another very real sense, however, they are closely related. Not only are both F-factors fundamentally linked by common chemical principles, but both F-factors work toward the same end. Both F-factors are part of overall watershed homeostasis that resists change - acidification by acidic deposition. To the degree that runoff to a receiving water contacts mineral material (in the watershed or in the stream or lake bottom) or acts in increase ion exchange loss of base mineral cations from soil (either base mineral cations held in highly acidic organic soils and peats or mineral soils), Fmineral acts to resist acidification. To the degree that water is in contact with highly acidic organic matter, Forganic acts to resist further acidification by decreasing the amounts of organic acids that would otherwise be in solution.

I propose that for "sensitive", currently acidic waters, the overall net increase of $\mathrm{H}^{+}$in surface waters as the result of acidic $\mathrm{H}_{2} \mathrm{SO}_{4}$ deposition is:

$$
\mathrm{H}_{\mathrm{H} 2 \mathrm{SO} 4}^{+}=\left(1-\mathrm{F}_{\text {mineral }}-\mathrm{F}_{\text {organic }}\right) \times\left(\left[\mathrm{SO}_{4} \star\right]\right)
$$


A review of peer-reviewed literature by Krug (1987) found 11 publications that report results of laboratory simulated acidic deposition/onganic soil and peat interaction.

"All of these studies report decreased concentrations of organic acids accompanied by relatively little measurable change in solution pH upon application of simulated acid rain." (Krug, 1987).

However, only one (James and Riha, 1986) of these 11 laboratory studies was performed so that the relative importances of $F_{\text {mineral }}$ and $F_{\text {organic }}$ could be quantitatively estimated.

Quantitative mechanistic study of highly acidic, organic-rich New York forest soils by James and Riha (1986) showed that Fmineral became progressively less important in buffering imput of acid with increasing soil acidity. This fact is well known in the aquatic effects literature and is used to support the theory that highly acidic, organic-rich soils and peats acid soils do little to remove acidity deposited on them. Acidification theory predicts that the more acidic the soil, the less able it is to filter out added $\mathrm{H}^{+}$(Braekke, 1976; Seip et al., 1979a, b; 1980; Van Breemen et al., 1984; Reuss et al., 1986; 1987). However, organic-acid buffering accounted for $38 \%$ to $79 \%$ of total buffering of acid input to highly acidic, New York forest soils. The greater levels of organic acid buffering occurred in the most highly acidic soils. The studied soils buffered from $67 \%$ to $96 \%$ of added $\mathrm{H}^{+}$(James and Riha, 1986).

Thus, for highly acidic, organic-rich soils of New york typical of "sensitive" watersheds in the Adirondacks and elsewhere in New York (James and Riha, 1986), only $4 \%$ to $33 \%$ of added strong acid went to increase the acidity of water passing through such soils. These results expressed in terms of acidic $\mathrm{H}_{2} \mathrm{SO}_{4}$ deposition to increase flux of $\mathrm{H}^{+}$are: 


$$
\begin{aligned}
& \left.\mathrm{H}_{\mathrm{H} 2 \mathrm{SO} 4}^{+}=\left(1-\mathrm{F}_{\text {mineral }}-\mathrm{F}_{\text {organic }}\right) \times\left(\left[\mathrm{SO}_{4}\right]\right]\right), \\
& \mathrm{H}_{\mathrm{H} 2 \mathrm{SO} 4}^{+}=\left(1-\mathrm{F}_{\text {mineral }}-(0.38-0.79)\right) \times\left(\left[\mathrm{SO}_{4} *\right]\right), \\
& \mathrm{H}_{\mathrm{H} 2 \mathrm{SO} 4}^{+}=(1-(0.67-0.96)) \times\left(\left[\mathrm{SO}_{4} *\right]\right), \\
& \mathrm{H}_{\mathrm{H} 2 \mathrm{SO} 4}^{+}=0.04-0.33\left[\mathrm{SO}_{4} *\right] .
\end{aligned}
$$

Accordingly, organic-acid buffering can be a very important process in highly acidic, organic-rich soils that is not accounted for in acidification theory.

These New York forest soils data, and data of the other 10 similar but less detailed studies of organic-acid buffering (Krug, 1987), offer an explanation for the Smoky Mountain soils' ability to acidify/buffer water and that greatest buffering occurred in the most acidic soils and water (Table 15). Organic-acid buffering also helps explain why Norwegian SNSF-Project laboratory and field studies show little or no measurable change in water pH upon addition of ambient levels of acidic deposition (Table 8; 9; 10; Figure 10; Seip et al., 1979a,b; 1980; Overrein et al., 1980).

Whereas the earlier Norwegian SNSF-Project studies did not measure the organic chemistry of waters (waters were assumed to be inorganic solutions), recently, mini-catchments in southermmost Norway were studied for the relative effects of acid rain and simulated "clean rain" on the inorganic and organic chemistry of runoff with a long-term acid exclusion experiment (1984 - 1987) at the Risdalsheia mini-catchments (Wright et al., 1988; Table 17).

Because of their very small size and high proportion of exposed bedrock and patches on thin, highly acidic, organic-rich soil, there is comparatively little opportunity for such Norwegian mini-catchments to modify runoff chemistry relative to larger, and more fully soil-covered catchments. Thus, such mini-catchments are recognized as being worst-case situations where the 
Table 17. Some Mean Chemical Data for Runoff from the Risdalsheia MiniCatchments in Southernmost Norway Receiving Amient Acidic Deposition and Simulated "Clean Atmospheric Deposition".

Chemical (Roof, Acid Rain) Mini-Catchment (Roof, Clean Rain) Mini-Catchment $\begin{array}{lllllllllll}\text { Parameter } & \text { Pre } & 1984 & 1985 & 1986 & 1987 & \text { Pre } & 1984 & 1985 & 1986 & 1987\end{array}$

\begin{tabular}{lccccccccccccc}
\hline $\mathrm{pH}$ & 4.1 & 4.0 & 4.1 & 4.1 & 4.1 & 4.1 & 4.0 & 4.1 & 4.1 & 4.1 \\
$\mathrm{NO}_{3}{ }^{\circ}$ & 72 & 37 & 22 & 38 & 37 & 62 & 5 & 9 & 17 & 7 & \\
$\mathrm{SO}_{4}{ }^{2-}$ & 106 & 112 & 99 & 131 & 106 & 137 & 73 & 68 & 64 & 53 \\
$\mathrm{TOC}$ & 5.3 & 9.1 & 14.1 & 10.7 & 9.4 & & 8.4 & 17.3 & 19.8 & 15.6 & 15.4 \\
\hline
\end{tabular}

Data from Wright et al., (1988).

TOC $=$ Tota1 Organic Carbon.

TOC in $\mathrm{mg} / \mathrm{L}$.

$\mathrm{NO}_{3}^{-}$and $\mathrm{SO}_{4}^{2-}$ in ueq/L. 
influence of acidic deposition on the acidity of water is expected to be most pronounced - where $\mathrm{H}^{+} \mathrm{H} 2 \mathrm{SO} 4$ is expected to be largest (Seip et al., 1979a,b; 1980; Overrein et al., 1980).

The long-term acid exclusion experiment at the Risdalsheia mini-catchments show no measurable influence of ambient levels of acidic deposition on the pH of runoff from the very small and rocky mini-catchments (Table 17; Wright et al., 1988). The results of wright et al. (1988; Table 17) are consistent with the results of the earlier mini-catchment studies (Seip et al., 1979a,b; 1980; Overrein et al., 1980). Wright et al. (1988) noted that effect of the clean precipitation treatment compared to that of ambient acidic deposition:

"The decline in strong-acid anion concentrations is compensated for partly by a decrease in concentrations of base cations (55\%) and partly by an increase in alkalinity (45\%)." (Wright et al., 1988).

"Alkalinity" is actually the anion deficit estimate of acid organic anions, $\mathrm{RCOO}^{-}$, because surface waters with $\mathrm{pH} 4.0-4.1$, as measured for the "clean rain" Risdalsheia mini-catchment experiment of Wright et al. (1988), do not have alkalinity. The choice of the term alkalinity by Wright et al. (1988) can be misleading in that it may cause readers to conclude that acidic deposition/watershed interaction for the Risdalsheia mini-catchments is well described by the theory of acidification - acidic deposition is acting to reduce alkalinity produced by carbonic acid weathering of minerals in the mini-catchments. This is not true. The buffering ascribed to by Wright et al. (1988) is buffering by organic acids not buffering due to $\mathrm{HCO}_{3}{ }^{-}$.

Relating the influence of acidic deposition on surface water $\mathrm{H}^{+}$in terms of "strong acid anions", in this case assuming total "strong acid anions" equal $\mathrm{SO}_{4}{ }^{2-}$, the results of acid-exclusion experiments for the Risdalsheia mini-catchments show: 


$$
\begin{aligned}
& \mathrm{H}_{\mathrm{H} 2 \mathrm{SO} 4}^{+}=\left(1-\mathrm{F}_{\text {mineral }}-\mathrm{F}_{\text {organic }}\right) \mathrm{X}\left(\left[\mathrm{SO}_{4} *\right]\right) \text {, } \\
& \mathrm{H}^{+}{ }_{\mathrm{H} 2 \mathrm{SO} 4}=(1-(0.55)-(0.45)) \mathrm{X}\left(\left[\mathrm{SO}_{4}{ }^{*}\right]\right): \text { replace }=\text { with } \sim \text { because it is } \\
& \text { unlikely that no change in } \\
& {\left[\mathrm{H}^{+}\right] \text {has occurred. }}
\end{aligned}
$$

$\mathrm{H}^{+} \mathrm{H} 2 \mathrm{SO} 4-0 \mathrm{X}\left(\left[\mathrm{SO}_{4} *\right]\right)$, or

$\mathrm{H}_{\mathrm{H} 2 \mathrm{SO} 4}^{+} \sim 0$.

Examination of the data from the Risdalsheia mini-catchments show two major reasons why the high ambient levels of acidic deposition in southermmost Norway have no measurable influence on runoff $\mathrm{pH}$ from the minicatchments:

1.) - runoff is acidified by strong acids produced by ion exchange in the absence of acidic deposition. Fmineral induced by acidic deposition masks natural strong acid production by ion exchange in the mini-catchments and, thereby, results in overestimation of change in strong acidity, and;

2.) - runoff is acidified by weak organic acids in the absence of acidic deposition. Forganic shows that the mini-catchments were acidified to a much greater degree by weak organic acids in the absence of acidic deposition.

Input/output budgets for the Risdalsheia mini-catchments (Wright, 1987) show that strong acid production by ion exchange is about $50 \%$ of $F_{\text {mineral }}$ induced by acidic deposition. Thus, in the absence of acidic deposition, natural levels of strong acidity in mini-catchment runoff are about $50 \%$ of Fmineral induced by acidic deposition. For the "acid rain" mini-catchment, deposition input of base cations $\left(\mathrm{Ca}^{2+}+\mathrm{Mg}^{2+}+\mathrm{Na}^{+}+\mathrm{K}^{+}\right)$for $1984-1986$ is $202 \mathrm{meq} / \mathrm{m}^{2}$ and dissolved runoff output is $225 \mathrm{meg} / \mathrm{m}^{2}$ (Wright, 1987). For the "clean rain" mini-catchment, deposition input of base cations for $1984-1986$ is $208 \mathrm{meq} / \mathrm{m}^{2}$ and dissolved runoff output is $187 \mathrm{meq} / \mathrm{m}^{2}$ (Wright, 1987). Thus, the input/output budget for the "clean rain" experiment indicates that $21 \mathrm{meq} \mathrm{H}^{+} / \mathrm{m}^{2}$ was produced by ion exchange for 1984 - 1986 which (for the $1,427 \mathrm{~mm}$ of runoff produced in $1984-1986)$ is $14.27 \mathrm{ueq} \mathrm{H}^{+} / \mathrm{L}$. 
Thus, the mean annual $\mathrm{pH}$ of runoff for the "clean rain" mini-catchment is naturally $\mathrm{pH}=4.83$ due to strong acids alone produced by ion exchange. Because of seasalt input in "clean rain" (Wright, 1987), strong acidity produced by ion exchange appears to be $\mathrm{HCl}$. As seen in Table 16, strong mineral acidity of the highly acidic waters in coastal Australia associated with highly acidic podzol soils and peats appears to be $\mathrm{HCl}$. In the presence of acidic deposition, however, $F_{\text {mineral }}$ causes output of base cations dissolved in runoff to be greater than depositional inputs, thereby, masking the natural production of strong acidity by ion exchange in the minicatchment.

Forganic induced by acidic deposition masks natural acidification by weak organic acids in the mini-catchments. Table 17 shows that "strong acid anions" $\left(\mathrm{NO}_{3}^{-}, \mathrm{SO}_{4}{ }^{2-}\right)$ are strongly influenced by the absence or presence of acidic deposition. Runoff from simulated "clean rain" had only about half the concentration of $\mathrm{NO}_{3}{ }^{-}+\mathrm{SO}_{4}{ }^{2-}$ present in runoff from acid rain for the four years of the experiment (74 ueq/L versus $145.5 \mathrm{ueg} / \mathrm{L}$, respectively). Despite a net difference of about $70 \mathrm{ueq} / \mathrm{L}$ in mean concentration of strong acid anions between the acid rain and simulated "clean rain" experiments, measured mean pH values were virtually identical for all four years of both treatments: $\mathrm{pH} 4.1$ for runoff from acid rain and $\mathrm{pH}-4.1$ for runoff from simulated "clean rain" (Table 17 ).

The relationship between change in strong acid anions and organic acids (as represented by $T O C$ ) is profound, obvious, and precisely as predicted by Forganic (Table 17). Concentrations of TOC are considerably higher in pH 4.1 runoff from the simulated "clean rain" treatment than they are in pH 4.1 runoff from "acid rain" (Table 17). And, just as important, there is a 
within-treatment relationship between concentrations of strong acid anions and TOC: mainly that the lower the concentration of strong acid anions the higher the concentration of TOC (Table 17). For the acid rain minicatchment, using a roof in 1984 resulted in a mean decrease in $\mathrm{NO}_{3}{ }^{-}$ concentration of $35 \mathrm{ueq} / \mathrm{L}$. The decrease in concentration of $\mathrm{NO}_{3}{ }^{-}$was accompanied by an increase in Toc from 5.3 to $9.1 \mathrm{mg} / \mathrm{L}$ (Table 17). The next year (1985) there was a further decrease in both mean concentrations of $\mathrm{SO}_{4}{ }^{2-}$ and $\mathrm{NO}_{3}{ }^{-}$for an additional decrease of $28 \mathrm{ueq} / \mathrm{L}$. Mean concentration of TOC rose again, this time to $14.1 \mathrm{mg} / \mathrm{L}$. In 1986 and 1987 , mean concentrations of strong acid anions increased and mean concentrations of TOC decreased to around $10 \mathrm{mg} / \mathrm{L}$ (Table 17). All of this time mean $\mathrm{pH}$ remained essentially unchanged at $\mathrm{pH} \sim 4.1$.

In conclusion, the principal effect of acidic deposition on runoff chemistry of mini-catchments in southermost Norway is the qualitative shift in the nature of the acidity of runoff, not its pH. In the absence of acidic deposition, runoff $\mathrm{pH}$ is about 4.1 , acidified primarily by weak organic acids and, secondarily, by strong mineral acids produced by ion exchange. It is interesting to note that the nature and quantitative proportions of weak and strong acidity of mini-catchment runoff from "clean rain" is quite similar to that of $\mathrm{pH} 4$ waters of coastal Australia (Table 16), an area that does not receive acidic deposition. In the presence of acidic deposition, runoff $\mathrm{pH}$ is still about 4.1 but acidified, however, primarily by strong acids from acidic deposition and, secondarily, by weak onganic acids.

Wright et al. (1988) concluded from the results of their acid-exclusion experiments for the Risdalsheia mini-catchments that:

"our data from the acid-exclusion experiment at Risdalsheia show that a decrease in acid deposition results in decreased concentrations of 
strong-acid anions in runoff. It is therefore likely that a major reduction in the flux of strong-acid anions will cause a major change in $\mathrm{pH}^{\prime}$ (Wright et al., 1988).

Their data (Table 17) support the conclusion of Wright et al. (1988) regarding the influence of acidic deposition on concentration of "strong acid anions" but do not support their conclusion regarding the influence of acidic deposition on pH. As is seen in Table 17, there is no measurable effect of "clean rain" versus "acid rain" on the mean annual pH values of runoff from the Risdalsheia mini-catchments.

Recently, Driscoll et al. (1988b) presented data that they claim supports the organic-acid buffering hypothesis of Krug and Frink (1983a), i.e., the principal influence of acidic deposition on currently acidic waters is to qualitatively change the nature of the acidity rather than the level of the acidity. Driscoll et al. (1988b) studied what are claimed to be two equivalent mountainous watersheds with similar altitudinal streamwater acidity gradients: one unpolluted (Jamieson Creek, British Columbia), and one polluted (Hubbard Brook, New hampshire). Because the highly acidic headwaters of Jamieson Creek are principally acidic due to organic acids and those of Hubbard Brook are principally acidic due to strong acids led Driscoll et al. (1988b) to conclude their study suggests that the principal effect of acidic deposition is the qualitative shift in the nature of acidity (shifting organic acidic waters to waters acidified by strong acids and containing appreciable concentrations of toxic, ionic aluminum) rather than the level of acidity, as previously believed.

In summary, the organic-acid-buffering hypothesis ( $F_{\text {organic }}$ ) is consistent with chemical principles applied previously only to the interaction of acidic/deposition with mineral landscape elements. This hypothesis simply 
acknowledges the nature and composition of the landscape elements that are principally responsible for highly acidic runoff to receiving waters (Krug and Frink, 1983a, b).

Laboratory and field experiments show that the pH-dependent solubility of humic acids is likely to play an important role in acidification/buffering of acidic, near-surface runoff in many "sensitive" watersheds. Addition of H2SO4 (and other strong acids) reduces solubilization of humic acids, transforming $\mathrm{RCOOH}$ solutions to $\mathrm{H}_{2} \mathrm{SO}_{4}$ (and other strong acids) solutions. Change in $\mathrm{pH}$ is much smaller than predicted by the dominant theory of acidification. The magnitude of estimated change in $\mathrm{SO}_{4}{ }^{2-}$ is much greater than change in $\mathrm{H}^{+}$and other cations. Again, anions, such as $\mathrm{SO}_{4}{ }^{2-}$, do not necessarily indicate source of $\mathrm{H}^{+}$and the change in concentration of "strong

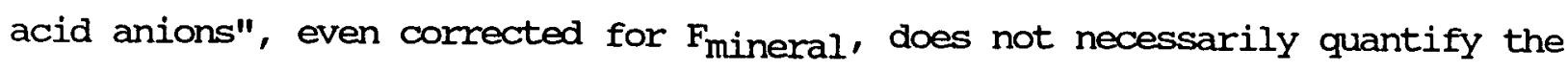
magnitude of change in concentration of $\mathrm{H}^{+}$. Laboratory and field experiments verify the hypothesis that the dominant theory of acidification can grossly overstate the magnitude and extent of surface-water acidification by acidic deposition by not considering the pH-dependent solubility of terrestrial humic substances. 


\subsubsection{Flocculation of Humic substances from Solution}

Many currently highly acidic surface waters in "sensitive" watersheds receive principally near-surface runoff that has passed through highly acidic, organic-rich material. Accordingly, it has been hypothesized that in pre-deposition times many currently acidic surface waters were naturally highly acidic and humic-rich (Krug and Frink, 1983a, b). Because acidic deposition necessarily influences surface-water chemistry, the interactions of acidic deposition with aquatic humic substances can be an important interaction to consider for many "sensitive" watersheds.

Acidic deposition can interaction with aquatic humic substances through the process of flocculation by which aquatic humic substances aggregate into particles large enough to settle out of solution. Physicochemical flocculation of humic substances from solution by cations can be categorized into two main categories:

1.) - Intermolecular bonding with $\mathrm{H}^{+}$(weak-acid buffering), and;

2.) - Intermolecular bonding with cations other than $\mathrm{H}^{+}$.

It appears that flocculation of aquatic humic substances by acidic deposition/aquatic humic substance interactions are particularly relevant to the issue of aquatic acidification because acidic deposition is widely considered to result in increased concentrations of both $\mathrm{H}^{+}$and ionic aluminum in surface waters. This chapter will show that both $\mathrm{H}+$ and ionic aluminum can have significant roles in the flocculation of aquatic humic substances. Furthermore, it will be shown that the interactions associated with the two mechanisms of flocculation categorized above, and which are represented by $\mathrm{H}^{+}$and ionic aluminum, do acidify and buffer water. 
The weak acid nature of aquatic humic acids that buffer against changing $\mathrm{pH}$ with the addition of $\mathrm{H}^{+}$also cause humic acids to flocculate upon addition of $\mathrm{H}^{+}$(Hayes and Swift, 1978; Davis and Mott, 1981; Ritchie and Posner, 1982; Krug and Isaacson, 1984). Flocculation causes concentration of dissolved organic carbon (DOC) to be reduced. Thus, even if accurate measurements of the acidification/buffering capacity of dissolved humic substances were made, (vis-a-vis Oliver et al., 1983; Gherini et al., 1985; Kramer and Davies, 1988), such measurements would not include the acid consumed and removed from solution by weak-acid buffering and flocculation of aquatic humic substances ${ }^{1}$ (Krug, 1987).

Humic substances can also be removed from solution through the mechanism of intermolecular bonding with cations other than $\mathrm{H}^{+}$, the most notable of

1.) - Hydrogen bonding is the principal mechanism by which humic acids in highly acidic humus and peats are held together. To get humic acids into solution, soil chemists add base to highly acidic peat or soil humus, such as pH 10 sodium hydroxide $(\mathrm{NaOH})$. The reverse of this procedure is to rapidly precipitate the solubilized humic substances by addition of strong acid, such as $\mathrm{pH} 1$ solution. The precipitation of humic substances from solution by addition of strong acid is a standard method long used to operationally define humic and fulvic acids. The relatively large humic acid molecules precipitate rapidly upon acid addition while the relatively small fulvic acid molecules do not. It is commonly believed that fulvic acids do not flocculate with additions of acid and, because about $80 \%$ of aquatic humic substances are operationally defined as fulvic acids (Thurman, 1984), it could be argued that $\mathrm{H}^{+}$-induced flocculation of aquatic fulvic acids does not occur. I disagree with this supposition for the following reasons: these fulvic acids were originally aggregated in a solid or gel state before they were solubilized by dissociation of hydrogen bonds through removal of $\mathrm{H}^{+}$so it should be expected that they can re-aggregate by hydrogen bonding induced by addition of $\mathrm{H}^{+}$; laboratory experiments show that fulvic acid molecules do, in fact, polymerize and aggregate upon addition of acid (e.g., Wershaw and Pinckney, 1971; Ritchie and Posner, 1982; Thurman et al., 1982; Cressey et al., 1983; Krug and Isaacson, 1984); that time required for precipitation from solution is strongly dependent on the original size of polymers is well established (e.g., Hsu, 1973), and; $\mathrm{H}^{+}$-induced aggregates of fulvic acids may become large enough to flocculate given the much longer retention times of lakes relative to the rapid separations necessary for benchtop chemical analysis. 
these being aluminum (Hargrove and Thomas, 1982). A practical and relevant demonstration of this process is the use of alum - a compound of potassium aluminum sulfate, $\mathrm{AlK}\left(\mathrm{SO}_{4}\right)_{2} \cdot 12 \mathrm{H}_{2} \mathrm{O}$ - in treating water to remove organic color.

Humic-aluminum interactions are naturally important in surface waters: especially highly acidic surface waters. Some aspects of these humicaluminum interactions are well known in the aquatic effects literature. For example, organically-complexed Al is generally believed to be the natural product of podzolization - the predominant soil-forming process of many "sensitive" watersheds in eastern North America and northern Europe. Organically-complexed $\mathrm{Al}$ is believed to be less toxic to aquatic organisms than ionic Al. Ionic Al in water is believed by many to be the unique product of acid rain (Driscoll et al., 1980; Johnson et al., 1981; U.S.EPA, 1984 ; Reuss et al., 1986; 1987).

The natural formation of organoaluminum complexes is only considered in the sense that natural processes are not "harmful" to or relevant to the issue of aquatic acidification. The same logic has been applied to the immobilization of humic acids by ionic $\mathrm{Al}$ and $\mathrm{Fe}$ in soils. This process is only considered in regard to humic acids "inactivating" the ability of ionic $\mathrm{Al}$ and $\mathrm{Fe}$ to sorb $\mathrm{SO}_{4}{ }^{2-}$. Also, these same organic acids are "informally" recognized as acidifying soils so that highly acidic, organic-rich soils and peats are considered to be "transparent" to acidic deposition - do little to stop the movement of either $\mathrm{H}^{+}$or $\mathrm{SO}_{4}{ }^{2-}$ through them (Seip, 1980; overrein et al., 1980; Johnson et al., 1981; National Research Council, 1981; Driscoll and Likens, 1982; Nilsson et al., 1982; Havas et al., 1984; Neal et al., 1986; Peterson, 1984; Van Breemen et al., 1984; Reuss et al., 1986; 1987; De 
Vries and Breeuwsma, 1987).

However, waters are acidified by complexation of organic acids with cations (such as $\mathrm{Al}, \mathrm{Fe}, \mathrm{Ca}$, and $\mathrm{Mg}$ ) that complex fairly strongly with humic acids. Such complexation releases $\mathrm{H}^{+}$thereby creating free hydrogen ion:

$$
2 \mathrm{RCOOH}+\mathrm{AlCl}_{3}+\mathrm{H}_{2} \mathrm{O}=\mathrm{Al}(\mathrm{OH})\left(\mathrm{RCOO}^{-}\right)_{2}+3 \mathrm{HCl} \text {. }
$$

In this case, the addition of $\mathrm{AlCl}_{3}$ to humic acid (RCOOH) results in the formation of hydrochloric acid $(\mathrm{HCl})$. The original source of the $\mathrm{H}^{+}$is flocculated out of solution. By considerations of solution chemistry alone, it appears, quite erroneously, that the water is acidified by addition of $\mathrm{HCl}$. If alum was added, it would appear, quite erroneously, that the water had been acidified by addition of $\mathrm{H}_{2} \mathrm{SO}_{4}$.

Figure 14 illustrates the creation of strong mineral acid from weak humic acid. Solutions of $\mathrm{AlCl}_{3}$ and humic acids are weak acid solutions, as described by their titration curves in Figure 14. However, when they are mixed together, their titration curves are displaced to increasingly more acidic $\mathrm{pH}$ values. Added $\mathrm{AlCl}_{3}$ displaces $\mathrm{H}^{+}$off humic acids (as described in the equation above). The resulting solutions are more acidic than either the solution of humic acid or $\mathrm{AlCl}_{3}$ by themselves.

The release of $\mathrm{H}^{+}$and subsequent lowering of $\mathrm{pH}$ is the creation of strong mineral acid from weak organic acid. It is a well known phenomenon in the aqueous chemistry literature. Aqueous chemists have for many years used the production of strong acid produced by salts added to organic acids as a classical means to quantify complexation of the cations of neutral salts with organic acids (Martel and Calvin, 1952).

The complexation of ionic Al with humic acids is naturally important in both soils and waters. The creation of strong mineral acids from 


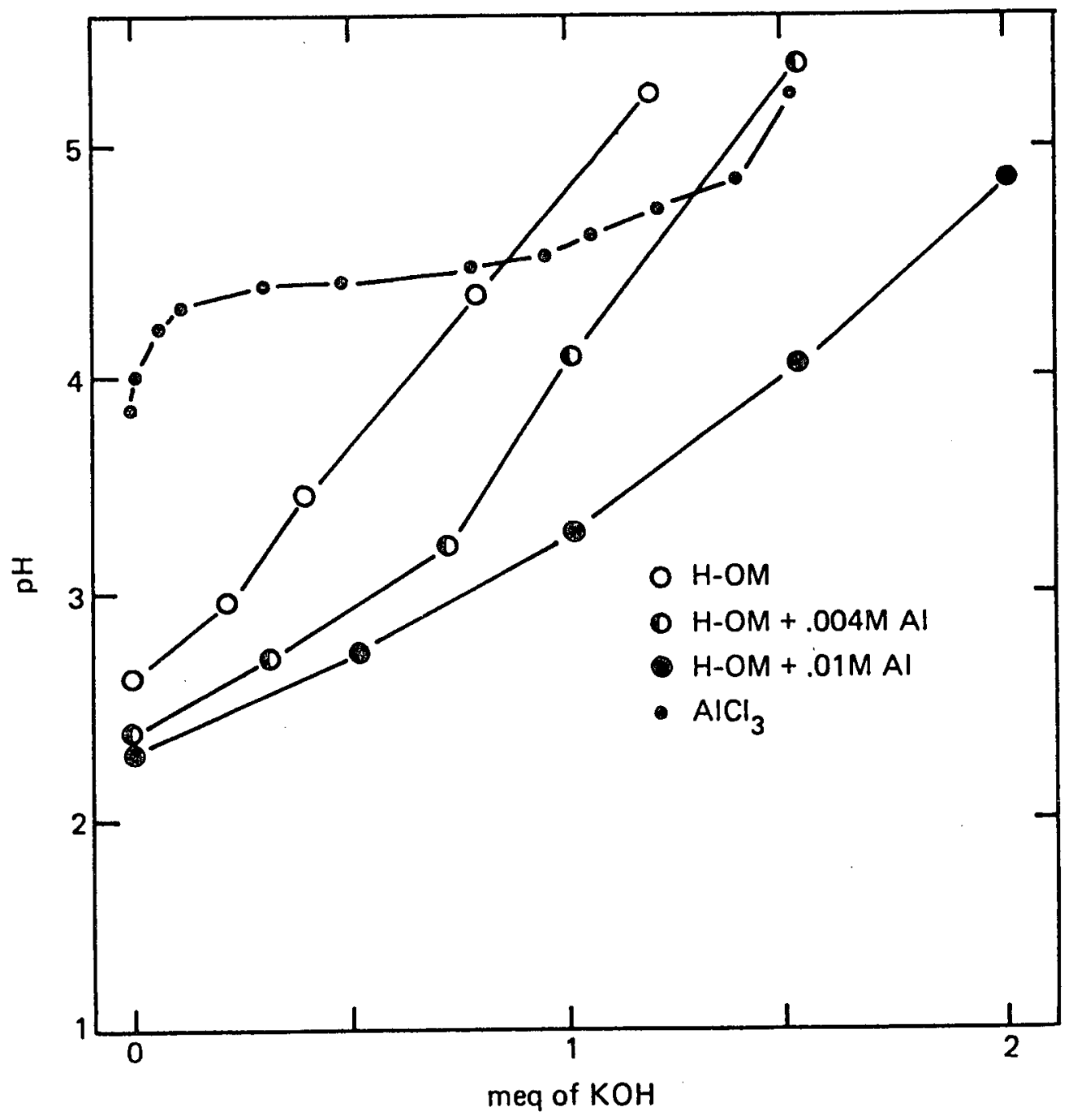

Figure 14. Potentiometric titration curves for acid-saturated peat in the presence of $0,0.004,0.01 \mathrm{M} \mathrm{AlCl}_{3}$, and $0.01 \mathrm{M} \mathrm{AlCl}_{3}$ alone. Displacement of peat titration curve to increasingly more acidic $\mathrm{pH}$ values with addition of increasing concentrations of $\mathrm{AlCl}_{3}$ illustrates the creation of strong acid from weak organic acids by ion exchange. From Hargrove and Thomas (1982). 
complexation of neutral salts (including Al) with humic acids is well recognized by soil chemists (e.g., Stevenson, 1977; Hargrove and Thomas, 1982), but is overlooked in regard to acidification of water (Krug, 1987). The interaction of aquatic humic substances with cations, such as aluminum (Al) and iron (Fe), create free $\mathrm{H}^{+}$that can be measured in solution as strong mineral acid. This source of strong acid from flocculated humic acids is not apparent from considerations of solution chemistry alone, as is done by acidification theory.

That flocculation of humic substances and Al occurs in Adirondack lakes has been shown for Darts Lake, downstream of Big Moose Lake (White and Driscoll, 1985). Krug (personal observation) is familiar with this drainage basin and has observed that humic flocculation can be particularly intense above Big Moose Lake. The bottom of Constable Creek (a major tributary to Big Moose Lake) can be covered by flocculated humic substances to the degree that the creek bottom appears to be covered by "black snow". Krug has also observed that flocculated humic substances can cover the bottom of Big Moose Lake itself.

The IIWAS study reported that the DOC concentration of water leaving acidic Woods Lake $(\mathrm{pH}-5)$ is about half that of water entering the pond. Likewise, about half of the Al entering the pond is retained in the pond. The amount of retained Al is significant, being equivalent to about one-fifth of the output of base cations from the watershed (Schofield et al., 1985). Assuming base cations represents an equivalent quantity of alkalinity, aluminum flocculated in Woods Lake alone may produce enough strong acid to titrate one-fifth of the alkalinity produced by net mineral weathering in the watershed. 
In conclusion, chemical theory, and laboratory and field experiments show that flocculation of aquatic humic substances occurs and can play an important role in acidification/buffering of surface waters in "sensitive" watersheds. Humic-aluminum interactions are naturally important in surface waters, especially highly acidic surface waters. Some aspects of these humic-aluminum interactions are well known in the aquatic effects literature, particularly that flocculation and detoxification of Al are involved. But the natural formation of organoaluminum complexes is selectively considered in acidic deposition studies only in the sense that this process is not "harmful" and is, therefore, not a contributor to acidification and is not associated with detrimental effects of aquatic acidification. That such complexation/flocculation can also convert weak organic acidity to strong mineral acidity is not considered by the theory of acidification. By not considering the contribution of organic complexation to strong acidity of surface waters, acidification theory, by default reasoning, necessarily attributes strong acidity to the one factor it considers capable of producing strong acidity - acidic deposition. By not considering that strong acid addition necessarily acts to protonate (re-associate $\mathrm{H}^{+}$) aquatic humic acids and can cause their aggregation and flocculation, acidification theory, by default reasoning, necessarily underestimates the role of aquatic humic acids in buffering and, thereby, necessarily overestimates the role of acidic deposition in acidification of surface waters.

Thus, acidification theory, by not considering acidification/buffering mechanisms associated with flocculation of aquatic humic substances, by default reasoning, necessarily overestimates the role of acidic deposition in the acidification of surface waters. 
3.7.2.4 Strong Acid Production by Weak Acids in Soils

An alternative hypothesis has been advanced that podzolization, the predominant soil-forming process in many sensitive watersheds of eastern North America and northern Europe (Bridges, 1970; Petersen, 1976; Krug and Frink, 1983a, b; Figure 9), can naturally impart strong acids and ionic aluminum to surface waters (Krug and Frink, 1983a, b; Krug et al., 1985; Krug, 1987). By this hypothesis, acidic deposition can increase concentrations of strong acids and ionic aluminum in surface waters by such watershed interactions as organic-acid buffering, removal of complexing organic anions, and ion exchange. However, contrary to acidification theory, the alternative hypothesis predicts that acidic deposition is not solely responsible for the existence of strong acids and ionic aluminum in runoff from highly acidic, organic-rich soils and peats typical of many "sensitive" watersheds (Krug and Frink, 1983a, b; Krug et al., 1985; Krug, 1987).

This alternative hypothesis of acidification is based upon consideration of the processes inherent to soil-forming process of podzolization. Podzolization is characterized by the formation of humic acids and subsequent complexation of a substantial portion of these humic acids in soil solution by ionic aluminum and iron (Joffe, 1949; Petersen, 1976). The creation of free $\mathrm{H}^{+}$by complexation of weak organic acids is well recognized by soil and solution chemists (e.g., Martell and Calvin, 1952; Stevenson, 1977; Hargrove and Thomas, 1982), but is overlooked by acidification theory (Krug and Frink, 1983a, b; Krug et al., 1985; Krug, 1987). Accordingly, it is hypothesized that highly acidic, organic-rich soils and peats typical of many "sensitive" watersheds of eastern North America and northern Europe) can naturally 
produce strong acids which is overlooked by acidification theory (Krug and Frink, 1983a, b; Krug et al., 1985; Krug, 1987).

This alternative hypothesis of acidification is also based on the assumption that ionic aluminum must be a natural constituent of podzolized soils because it is required by the pozolization, soil-forming process to flocculate and complex organic acids. Additionally, that aluminum toxicity is a pervasive and natural problem in highly acidic forest soils, regardless of whether the area is receiving acidic deposition or not (e.g., Joffe, 1949; van Wambeke, 1976), further supports chemical complexation theory and experiments that toxic, ionic aluminum in the environment can be a natural product of highly acidic soils (Krug and Frink, 1983a, b; Krug et al.., 1985; Krug, 1987).

That omission of such processes by acidification theory can result in significant error in overestimating the role of acidic deposition is suggested by the aquatic effects literature itself. It is well recognized in the aquatic effects literature that organometallic complexation reactions of the podzol soil-forming process have a significant influence on the chemistry of many "sensitive", acidic surface waters, i.e., many "sensitive" acidic surface waters have appreciable concentrations of organically-complexed aluminum and complexation of humic acids by ionic $\mathrm{Al}$ and Fe within the drainage basin tends to remove most of the humic acids from runoff before it enters acidic surface waters (e.g., Driscoll et al., 1980; Johnson et al., 1981; U.S. EPA, 1984; Reuss et al., 1986; 1987). For example, lysimeters show that soil solution draining highly acidic, organic-rich surficial soil material of the Woods Lake watershed in the Adirondacks average $20 \mathrm{mg}$ DOC/L (Schofield et al., 1985). But the same study shows that most of this 
solubilized organic matter never makes it to woods Lake; water entering Woods Lake averages $4 \mathrm{mg}$ DOC/L (Schofield et al., 1985).

It has become recently recognized that the podzolization soil-forming process can play an important role in altitudinal surface water acidity and chemistry gradients. It appears that many acidic lakes and streams in "sensitive" watersheds are fed principally by near-surface runoff whose water chemistry reflects the podzolization process of surficial soil horizons $(0$ and A horizons) :

"The factors thought to make these landscapes sensitive to acid rain also limit neutralization of runoff acidified by acid soil. The thin and rocky soils that develop on these areas naturally produce such thick humus that they are often classified as organic soils $(17,24$, 27-31), and they have a lower pH than the thicker soils downslope (27, 31-33). This topographic gradient in soil chemistry and other properties, where the upland soils are "leaky" and act as A horizons and the lower-lying sites act as B horizons, is known as a geochemical soil catena (34). Thus, a gradient in stream acidity paralleling a soil catena in mountainous areas should not be surprising, although it is not always evident. Such gradients have been observed at Hubbard Brook and other mountainous watersheds in the northeastern United States, but the acidification has been attributed entirely to acid rain." (Krug and Frink, 1983a).

The role of organometal complexation in the podzol soil-forming process in relation to surface-water chemistry has been subsequently verified by data from the Hubbard Brook Experimental Forest watershed in the White Mountains of northern New Hampshire. While there is considerable watershed variability, there is a general altitudinal gradient in soils, vegetation, and hydrology similar to those described for the Adirondack Mountains of New York (Figure 9) and the Smoky Mountains of North Carolina (Jones et al., 1983; Table 15). In the Hubbard Brook watershed, soils become thinner and more acidic with altitude, the forest ecosystem becomes more coniferous and acidophilic, and streamwater becomes more acidic with altitude (Likens et al., 1977; Johnson; 1979; Driscoll et al., 1985; 1988a,b; Lawrence et al., 
1986). Low altitude streamwater is circumneutral with very low concentrations of dissolved organic carbon (DOC) and aluminum. With altitude, streamwater becomes more acidic and organic- and aluminum-rich with mean $\mathrm{pH}$ as low as 4.1 and mean $\mathrm{DOC}$ for $\mathrm{pH} 4.1$ headwaters between 12 and 15 mg/L (Lawrence et al., 1986; Driscoll et al., 1988b). Elevated levels of total aluminum in the highly acidic headwaters reflect elevated levels of organically-complexed aluminum, and other forms of aluminum (including ionic aluminum), in the organic-rich, highly acidic headwaters of the Hubbard Brook watershed (Lawrence et al., 1986).

Similar altitudinal and drainage relationships between $\mathrm{pH}$, DOC, and aluminum chemistry have been reported for a number of acidic lakes over a relatively large area in the Adirondacks (Driscoll et al., 1987; 1988b) .

While acidity in the Hubbard Brook watershed and for the reported Adirondack lakes is positively correlated to DOC and, thereby, humic acids, it appears that strong acidity is the principal form of acidity in these highly acidic, relatively organic-rich headwaters (Lawrence et al., 1986; Driscoll et al., 1987; 1988b). Driscoll et al. (1988b) agree with the organic acid buffering hypothesis (qualitative change from weak acidity to strong acidity induced by acidic deposition) but the possibility that complexation of humic acids with metals can naturally, to some extent, create strong acidity and ionic aluminum in the absence of acidic deposition has not been suggested (Lawrence et al., 1986; Driscoll et al., 1987; 1988b) .

However, that the podzol soil-forming process can result in the creation of strong acidity and ionic aluminum in water has been addressed in an area that can be considered as a control area - an area with highly acidic, organic-rich podzol soils and associated peats but not having acidic 
deposition. The podzol soil-forming process that predominates in many "sensitive" watersheds of eastern North America and northern Europe also occurs in some unpolluted coastal areas of Australia. Australian soil scientists have shown that podzolization can produce both strong mineral acidity as well as weak organic acidity (Reeve and Fergus, 1983; Reeve et al., 1985). The coastal area of eastern Australia studied by Reeve and Fergus (1983) and Reeve et al. (1985), the Cooloola National Park and adjoining Noosa River area, have podzolized sandy soils and associated acidic peats but does not have acidic deposition. The inorganic chemistry of surface waters here reflects the chemistry of precipitation containing very dilute seaspray and no acidic $\mathrm{H}_{2} \mathrm{SO}_{4}$ deposition: mean anion concentrations for acidic waters are $\mathrm{Cl}^{-}=91 \%$ and $\mathrm{SO}_{4}{ }^{2-}=9 \%$ of total anion concentration, which is exactly the proportions found in seawater (Reeve et al., 1985; Table 16).

Reeve and Fergus (1983) demonstrate that podzol soils can create highly acidic clearwaters by leaching acidic black water through subsoil (C) horizons of two podzol soils (Table 18) obtained from watersheds of the Cooloola-Noosa area in Australia that have naturally highly acidic clear and colored waters (Table 16). The highly acidic cooloola-Noosa black water (pH $=4.5 ;$ color $=106$ platinum units) is transformed into remarkably clear and highly acidic water ( $\mathrm{pH}=4.6 ;$ color $=2$ platinum units) after passing through the $\mathrm{C}$ horizon material (Table 18). These data suggest that clearwaters acidified by mineral acids can be a natural by-product of the podzolization soil-forming process.

Most highly acidic Australian waters studied were considered by Reeve et al. (1985; Thompson, personal communication; Table 16) to be acidified by a 
Table 18. Composition of Australian Humic Water Before and After Leaching Through Two Podzol A and Two Podzol C Horizons.

\begin{tabular}{|c|c|c|c|c|c|}
\hline \multirow{2}{*}{ Parameter } & \multirow[t]{2}{*}{$\begin{array}{l}\text { Humic Water } \\
\text { Before Leaching }\end{array}$} & \multicolumn{2}{|c|}{$\begin{array}{l}\text { Leached through } \\
\text { A Horizons }\end{array}$} & \multicolumn{2}{|c|}{$\begin{array}{c}\text { Leached through } \\
\text { C Horizons }\end{array}$} \\
\hline & & 1 & 2 & 1 & 2 \\
\hline Color (Pt Unit) & 106 & 106 & 106 & 2 & 2 \\
\hline & 4.5 & 4.4 & 4.0 & 4.6 & 4.6 \\
\hline $\mathrm{Al} \quad(\mathrm{mg} / \mathrm{L})$ & 0.22 & 0.32 & 0.36 & 0.47 & 0.63 \\
\hline $\mathrm{Fe}(\mathrm{mg} / \mathrm{L})$ & 0.06 & 0.10 & 0.13 & 0.04 & 0.11 \\
\hline
\end{tabular}

Data from Reeve and Fergus (1983). 
natural mix of weak and strong acidity of relative proportions similar to that observed in the Adirondacks (Table 16). The existence of highly acidic clearwaters due to podzolization appears to be due to the presence of ionic Al and Fe which flocculate out humic acids but is limited to conditions where there are insufficient bases in subsoils with which to neutralize H+. The absence of sufficient bases appears to be the consequence of long periods of intense weathering of coastal marine quartzose sands uninterrupted by glaciation (Thompson, 1981; Thompson and Moore, 1984; Reeve et al., 1985), as is also observed in other sandy coastal plain areas not subject to recent glaciation, such as the Atlantic Coastal Plain of the eastern United States extending from New Jersey into Florida (Gammon et al., 1953; U.S. Soil Conservation Service, 1967; Long et al., 1969; Rhodehamel, 1973; Holzhey et al., 1975; Krug, 1981; Means et al., 1981).

The leaching experiment of Reeve and Fergus (1983) also indicates that ionic aliminum can naturally issue from highly acidic, podzol soils. The naturally, highly acidic clearwater issuing from podzol soil in their experiment contained considerable concentrations of Al, averaging about 500 $\mathrm{ug} / \mathrm{L}$ (Table 18). Some of this dissolved aluminum is presumably toxic, ionic aluminum given what is essentially the absence of humic substances and the highly acidic pH of 4.6 of the leachate (Table 18).

Surface water chemistry data support the conclusion drawn from the soil leaching experiment of Reeve and Fergus (1983; Table 18) that aluminum, and other metals, can naturally be in waters issuing from highly acidic soils. Highly acidic and colored waters of the cooloola-Noosa area can have anion deficits (Table 16) that typify waters acidified by large concentrations of humic acids. However, highly acidic, clearwaters of cooloola-Noosa having no 
anion deficit (Table 16) and even anion excesses of up to $75.7 \mathrm{ueq} / \mathrm{L}$ have been reported (Reeve et al., 1985). As seen in Table 4, low DOC (DOC<2 mg/L) $\mathrm{pH}<5.0$ NSWS eastern lakes average about $25 \mathrm{ueq} / \mathrm{L}$ anion excess - can be attributable to ionic metals not accounted for in the ion balance equation. The large anion excesses of some naturally acidic Australian waters equal the highest found in the NSWS of eastern U.S. lakes (Kanciruk et al., 1986).

That highly acidic, organic-rich soil naturally releases highly acidic waters containing ionic aluminum and is highly toxic to fish has been demonstrated by the research of Jones et al. (1983). Jones et al. (1983) passed simulated unpolluted rain through highly acidic, organic-rich soil (Table 15). Not only did this soil strongly acidify water (Table 15), but it also imparted concentrations of monomeric ionic Al to water (Jones et al., 1983). Water derived from Smoky Mountain soil by simulated unpolluted rain was highly toxic to trout even when greatly diluted (Jones et al., 1983).

In summary, acidification theory predicts that (in the absence of acid mine drainage) acidic deposition is the only factor capable of sustaining strong acidity in surface waters. Scientific consensus is so strong about the presence of ionic Al being an artifact of acidic deposition that virtually any indication of ionic Al in water is taken as proof of acidic deposition's detrimental, toxic effect on surface waters (Almer et al., 1974; Braekke, 1976; Overrein et al., 1980; Driscoll et al., 1980; Henriksen, 1980; Seip, 1980; Haines, 1981; Johnson et al., 1981; Driscoll and Likens, 1982; U.S. EPA, 1984; Van Breemen et al., 1984; 1985; Driscoll and Newton, 1985; Gherini et al., 1985; Reuss et al., 1986; 1987; Brakke et al., 1987; Malanchuk and Turner, 1987; Brakke et al., 1988; Reuss, 1988; Wright et al., 1988). 
An alternative hypothesis has been advanced which acknowledges that acidic deposition can increase concentrations of strong acids and ionic aluminum in surface waters but claims acidic deposition is not solely responsible for the existence of strong acids and ionic aluminum in runoff from highly acidic, organic-rich soils and peats typical of many "sensitive" watersheds (Krug and Frink, 1983a, b; Krug et al., 1985; Krug, 1987).

Considerable data published in the scientific literature contradict the reported scientific consensus that acidic deposition is solely responsible for the existence of strong acidity and ionic aluminum in surface waters. The podzolization soil-forming process that predominates in many "sensitive" watersheds in eastern North America and Northern Europe necessarily produces strong acidity and ionic aluminum. Cases are presented for southern Hemisphere watersheds where the podzolization soil-forming process acidifies water strictly through the production of strong acidity and essentially all aluminum in solution is ionic. However, it is expected that weak organic acids and organically-complexed aluminum are naturally present, if not predominant, in runoff issuing from highly acidic soils and peats typical of many "sensitive" watersheds.

This review suggests that research is needed to quantify the preacidification concentrations of strong acid and ionic aluminum in runoff from highly acidic soils of many "sensitive" watersheds. Only when this is accomplished can quantitative estimates be derived for the influence of acidic deposition on the chemistry of near-surface runoff in many "sensitive" watersheds of eastern North America and northern Europe. 


\subsection{Paleolimnological Investigations}

Paleolimnology offers an independent means by which to test the acidification theory and the alternative hypotheses of acidification. Paleolimnology can provide a direct answer to the question - in the preindustrial era, were currently acidic, $\mathrm{pH}<5.5$, lakes $\mathrm{HCO}_{3}{ }^{-}$solutions of mineral bases, $\mathrm{pH}>5.5$, as predicted by the acidification theory, or were most currently acidic lakes naturally acidic prior to acidic deposition, as predicted by the alternative hypotheses of acidification?

I have been able to find reported paleolimnological investigations for 29 currently acidic surface waters in southern Norway and "sensitive" areas of the northeastern United States - two areas in which numerous studies have claimed recent widespread and profound acidification of surface waters. And two of these acidic lakes examined paleolimnologically were also the focus of especially intensive, long-term acidification research which has been used to support acidification theory - Lake Langtjern in southern Norway, and Woods Lake in the Adirondack Mountains of New York. Accordingly, conclusions of studies based on acidification theory and paleolimnology can be directly made for both Lake Langtjern and Woods Lake.

The contention that widespread, recent acidification of surface waters has occurred in southern Norway and the northeastern United States is not well supported by the results of paleolimnological investigations.

Review of paleolimnological investigations shows that 9 of 10 lakes in southern Norway with present pH less than 5.5 also had a pH less than 5.5 in pre-industrial times (Scruton et al., 1987; Krug, 1988). Lake Langtjern is one of the 10 lakes examined (Overrein et al., 1980; Scruton et al., 1987). 
Its watershed and water chemistry have been studied continuously for at least seven years, 1974 - 1980, (Henriksen and Wright, 1977; Overrein et al., 1980; Wright, 1983) and this lake has also had the last 800 years of its sediment examined paleolimnologically (Overrein et al., 1980; Scruton et al., 1987).

By acidification theory, Lake Langtjern is considered to be a model case of acidification by acidic deposition. It is a headwater lake with a very short water retention time ( 0.2 years) in the interior of southern Norway so that:

"streamwater and lakewater chemistry at Langtjern is dominated by strong acids, particularly sulfate, the major anion. Langtjern is thus highly affected by chemical components such as $\mathrm{H}^{+}$and $\mathrm{SO}_{4}$." And, in conclusion, "If the $\mathrm{H}^{+}$budget for Langtjern is typical then we have an explanation for the general observation that uppermost, head-water lakes are often lowest in $\mathrm{pH}$ and lose their fish populations first (Wright \& Johannesen 1980)." (Wright, 1983).

However, there was no attempt to reconcile the conclusion derived from acidification theory (Wright, 1983) with the earlier published paleolimnological results (Overrein et al., 1980) that Lake Langtjern has been acidic for at least the last 800 years. Over the last 800 years, Lake Langtjern was reported to be most acidic, pH-4.3, around 1200 A.D. (Overrein et al., 1980; Scruton et al., 1987). Current $\mathrm{pH}$ is reported to be -4.7 (Henriksen and Wright, 1977; Overrein et al., 1980; Wright, 1983; Scruton et al., 1987). Thus, paleolimnology does not support the conclusion derived from acidification theory that lake Langtjern (and similar headwater lakes in southern Norway) was transformed to an acidic lake from a lake with bicarbonate alkalinity (pH greater than 5.5 ) .

Davis et al. (1983) examined a number of lakes in southern Norway and New England (5 in New England and 6 in southern Norway) with pH values currently less than $\mathrm{pH}$ 5.5. While they reported evidence suggesting recent but only 
very slight changes in acidity (and only for some, not all lakes examined) correlated to increased acidic deposition, they also reported evidence suggesting that land-use changes and other types of disturbance can influence the acidity of surface waters:

"Even minor land use changes or disturbances in lake watersheds introduce ambiguity to the sedimentary evidence relating to atmospheric influences." Furthermore, "It is very difficult to find lakes whose sediments are completely free of the influences of human and non-human disturbances to the watersheds" (Davis et al., 1983).

In conclusion, the Davis et al. (1983) study showed that currently acidic lakes were acidic in pre-industrial times and it supports the changing landuse hypothesis of Rosenqvist $(1978 ; 1980)$.

Subsequently, Davis et al. (1985) studied 2 lakes in southern Norway to determine not only changes in $\mathrm{pH}$, but also changes in onganic acidity (changes in total organic carbon $(\mathrm{TOC})$ ). The 2 lakes studied are now subjectively described as clearwaters with relatively low concentrations of TOC, $2.2-3.2 \mathrm{mg} / \mathrm{L}$ (Davis et al., 1985). But in the past their TOC levels were 2 - 3 times higher than the present:

"The results indicate that in pre-industrial times both lakes were acidic ( $\mathrm{pH}$ 4.9-5.1, no bicarbonate alkalinity) and relatively humic (TOC 6-9 p.p.m.). This acidification started around 1920 at Hovvatn and in the 1940's at Holmvatten, and was accompanied by TOC decreases of 3-6 p.p.m. This supports the hypothesis and suggests that the acidification of such lakes transformed them from organic weak acid dominated to mineral strong acid dominated" (Davis et al., 1985).

In conclusion, the study of Davis et al. (1985) supports the organic acid buffering hypothesis (Krug and Frink, 1983a).

For the northeastern United States, the National Academy of Science review of paleolimnological studies found that of 16 lakes examined with current acidic inferred $\mathrm{pH}$ values $(\mathrm{pH}<5.5), 14$ of the 16 also had acidic pre-industrial inferred pH values of less than 5.5 (Charles and Norton, 
1986). Charles and Norton (1986) concluded:

"The number of lakes with a pre-1800 diatom-inferred pH value less than 5.5 suggests that these types of lakes were relatively common in the Adirondack Mountains and New England before the Industrial Revolution" (Charles and Norton, 1986, p.357).

Charles and Norton (1986) observed that there has been some acidification of some currently acidic surface waters (but not all currently acidic surface waters) that appeared to correlate with the advent of acidic deposition. But what acidification had been observed was not nearly as great as is predicted by the dominant theory of acidification which assumes that bicarbonate alkalinity waters were titrated to sulfuric acid waters (Charles and Norton, 1986). An example of this was given in Chapter 3.7.2.1 where very dilute water with only $60 \mathrm{ueq} / \mathrm{L}$ of $\mathrm{HCO}_{3}{ }^{-}$produced by mineral weathering is calculated to have a pre-industrial pH of 7.1 , which is a much higher $\mathrm{pH}$ value than 5.5. Thus, the observation between acidification predicted by acidification theory and that acidification observed (if seen at all) is remarkably large.

Paleolimnological analysis, laboratory studies and observations of loss of humic color from waters led Norton and Charles (1986) to conclude that for most currently $\mathrm{pH}<5.5$ waters examined, acidic deposition was converting humic acid waters to sulfuric acid waters. This conclusion supports the organic acid buffering hypothesis (Krug and Frink, 1983a). The principal detrimental effect for most currently acidic surface waters does not appear to be acidification (because these waters were already acidic) but the loss of humic acids which can result in increasing proportion of ionic Al (Davis et al., 1985; Krug et al., 1985; Charles and Norton, 1986).

Lakes that appear to have been bicarbonate waters which could have become acidified by acidic deposition appear to be the exception rather than the 
rule in the northeastern United States (Norton and Charles, 1986). One of the two lakes in the Northeast that has been transformed from a pH>5.5 lake to a currently acidic lake is Big Moose lake in the Adirondack Mountains of New York. It has undergone the largest recorded change in $\mathrm{pH}$ of any currently acidic water in the Northeast that has been examined paleolimnologically, having gone from around pH 5.8 to 4.8 (Norton and Charles, 1986). However, the magnitude of $\mathrm{pH}$ change for even Big Moose lake is considerably less than commonly believed to be possible by acidification theory. By acidification theory, "sensitive", acidic lakes have an estimated change in $\mathrm{F}$ of about 0.2 (Henriksen and Brakke, 1988). Nevertheless, Big Moose Lake has a calculated change in $\mathrm{F}$ of 0.76 , or $76 \%$ of input of $\mathrm{H}_{2} \mathrm{SO}_{4}$ is converted to basic sulfate (Charles et al., 1987). Furthermore, historical observations of changes in water color, paleolimnological records of changes in diatoms and chrysophytes all indicate that in pre-deposition times the water of Big Moose Lake was more highly colored and humic rich than present (Charles et al., 1987).

Like Lake Langtjern in southern Norway, Woods Lake in the. Adirondacks has had both intensive watershed study and paleolimnological investigation. Indeed, Woods Lake is the most intensively studied acidic ( $\left.\mathrm{pH}^{-5}\right)$ lake in the northeastern United States. It was used to develop the ILWAS model, the most data intensive, mechanistic, and comprehensive of the three process-oriented acidification models used by NAPAP (Malanchuk and Turner, 1987). The ILWAS model predicts that a 50\% reduction in sulfate deposition will cause the $\mathrm{pH}$ of Woods Lake to rise from $\mathrm{pH}-5$ to $\mathrm{pH}-6$ during the growing season, late April through November (Malanchuk and Turner, 1987), the time when diatoms (the fossils of which were used in the paleolimnology study of Woods Lake) are 
principally deposited in sediments (Davis et al., 1988). Nevertheless, two separate paleolimnological studies of Woods Lake indicate that it was pH-5 in pre-industrial times (Del Prete and Galloway, 1983; Davis et al., 1988). The reported composition of pre-industrial diatoms of Woods lake is different than the current composition even though both current and pre-industrial era waters are at essentially the same $\mathrm{pH}$ (Davis et al., 1988) which suggests a qualitative shift in the nature of the acidity, such as a change from acidic humic water to acidic clearwater.

Woods Lake underwent a marked rise in $\mathrm{pH}$ to above 5.5 that corresponded to large fires and cutting around the turn-of-the-century (Davis et al., 1988). Subsequently, Woods Iake became re-acidified (Davis et al., 1988). It was reported that acidic deposition is responsible for the reacidification of Woods Lake following the intensive disturbance around the turn-of-the-century (Davis et al., 1988). However, it should be noted that Woods lake is now located in the Adirondack Park and Forest Preserve which is protected from any such re-occurrence of destructive fires and where highly destructive land use (such as was practiced earlier) is forbidden. Accordingly, acidic deposition may not be the only possible explanation for the re-acidification of Woods Lake.

Paleolimnological studies of three currently acidic lakes in the northeasterm United States have been reported that are not summarized in the National Academy of Science review (Charles and Norton, 1986). They are: Lake Colden ( $\mathrm{pH}-5)$, an high altitude lake in the High Peaks Region of the Adirondacks (Douglas and Smol, 1988); Duck Pond (pH-4.6) in the Cape Cod National Seashore in Massachusetts (Winkler, 1985; 1988), and; Sargent Mountain Pond (pH 4.6) in Acadia National Park in Maine (Kahl et al., 1985). 
Like the majority of other Northeast lakes examined, all three of these currently acidic lakes were found to be acidic in pre-industrial times (Kahl et al., 1985; Winkler, 1985; 1988; Douglas and Smol, 1988).

Thus, out of 19 currently acidic lakes in the Northeast examined whose data have been reported, 17 were acidic in pre-industrial times. As in southern Norway, roughly speaking, only about 1 in 10, or about $10 \%$ of currently acidic lakes were found to have pH values greater than 5.5 in preindustrial times.

Lake colden, is a high altitude, clearwater lake $(\mathrm{pH}=5.00, \mathrm{TOC}=3.21$ $\mathrm{mg} / \mathrm{L}$ (Krug, personal observation, August 28, 1985)) in the High Peaks of the Adirondacks. Lake colden has been used as a symbol of a scenic, high altitude trout lake that has become sterilized by acidic deposition. It was well known as an excellent trout lake in the early 1900's but is currently acidic (pH 5) and fishless (Douglas and Smol, 1988). However, paleolimnology shows that it was highly acidic in pre-industrial times. Furthermore, after the watershed began to be cut and burned, water pH levels went up, apparently allowing fish to survive. In the 1920's, the State of New York acquired the land around lake colden and added it to the Adirondack Park and Forest Preserve, protecting it from fire and lumbering. Subsequently, lake pH fell towards pre-settlement levels and fish disappeared (Douglas and Smol, 1988).

"Its present fishless state is not an umprecedented event, as in 1859 it was described as supporting 'only lizards and leeches in its cold waters' (Masten, 1968)" (Douglas and Smol, 1988).

In conclusion, the absence and presence of fish, and acidity of water in Lake Colden appears to strongly related to land-use change.

Duck Pond is an acidic $\left(\mathrm{pH}_{4}, 6\right)$ clearwater seepage pond of exceedingly high transparency in Cape cod (Winkler, 1985; 1988). Paleolimnological 
investigation indicates that Duck Pond a naturally acidic clearwater pond that is no more acidic now than it was 12,000 years ago. At times in its past it has been more acidic than it is at present (Winkler, 1985; 1988). However, the pond experienced several pH 5 to 6 excursions over the last 12,000 years. The latest high $\mathrm{pH}$ excursion occurred in the 1600's when colonists came in and cleared the forest. Upon land abandonment around 1800, pH dropped within decades to its present level from about pH 5.5 (Winkler, 1985; 1988).

Three more lakes in the Cape cod National Seashore are currently undergoing paleolimnological investigation. Preliminary results indicate that these three lakes are similar to Duck Pond in history of their watersheds and water chemistries (Winkler, personal communication). It appears that lake acidity is strongly related to man-made and natural watershed disturbances in the Cape Cod National Seashore.

Sargent Mountain Pond is a clearwater (mean color 14 Co-Pt units, perfect ion balance) acidic ( $\mathrm{pH}^{4.6)}$ pond in Acadia National Park in Maine whose inferred pH has not significantly changed in the approximately 300 years represented in the sediment core. No land-use changes for its watershed were reported (Kahl et al., 1985).

In summary, acidification theory is not well supported by paleolimnological studies. The alternative hypotheses of acidification are well supported by paleolimnological investigations. These studies indicate that approximately $90 \%$ of currently acidic surface waters examined in southern Norway and the northeastern United States are naturally acidic waters that were acidic in the pre-industrial era. Lakes that appear to have been bicarbonate waters which could have become acidified by acidic 
deposition appear to be the exception rather than the rule.

The effects of land-use change and other types of watershed disturbance on acidification of surface waters is reported for many of the lakes examined. Acidification of surface waters by acidic deposition appears to be superimposed upon natural processes of acidification. The principal influence of acidic deposition appears not to be a marked acidification of surface waters but rather a qualitative shift in the nature of acidity from organic acid water to sulfuric acid water. Paleolimnology suggests that most naturally acidic surface waters were more organic rich in the pre-industrial era, although at least one naturally acidic surface water was apparently naturally acidified by strong acidity produced by soil/plant ion exchange.

Paleolimnological studies suggest that the principal detrimental aquatic effect of acidic deposition may be the loss of humic substances in naturallyacidic surface waters and a concomitant shift in the speciation of aluminum. 
3.9 Observations of Naturally-Acidic Waters Associated with Acidic Soils not Exposed to Man-Made Acidic Deposition

The absence or presence of acidic surface waters in "sensitive" watersheds not receiving man-made acidic deposition can be used as an independent test of the fundamental premises of acidification theory and the alternative hypotheses of acidification (and results of paleolimnology):

1.) - Acidification theory - currently acidic surface waters are acidic because of acidic deposition.

2.) - Alternative hypotheses of acidification (and results of paleolimnology) - acidification of surface waters by acidic deposition is superimposed upon natural processes of acidification. Most currently acidic surface waters were acidic in pre-industrial times. The principal effect of acidic deposition on currently acidic surface waters has been a qualitative shift in the nature of acidity.

The first objective of such a test is to determine if there are "sensitive" watersheds in areas of the world not receiving man-made acidic deposition that are analogous to "sensitive" watersheds said to have been acidified by "acid rain". If so, the second objective is to obtain water chemistry data for these "sensitive", unpolluted watersheds to determine if highly acidic surface waters do, or do not, exist in percentages comparable to similar "sensitive" regions receiving acidic deposition.

The highly acidic, humic-rich landscapes typical of many "sensitive" watersheds in eastern North America and northern Europe are the result of the soil-forming process known as podzolization. The development of highly acidic, organic-rich podzol soils and associated peaty soils is most favored by cool, moist climates of the type encountered in recently-glaciated terrains such as southeast Canada, the Adirondack Mountains, New England, 
parts of the upper Midwest, southern Scandinavia, and maritime portions of northern mainland Europe. The intensity of the podzol soil-forming process diminishes as climate becomes progressively colder (to the north), drier (to the west in North America and east and south in Europe), and warmer to the south in both Europe and North America (Bjorlykke, 1928; Jenny, 1941; Joffe, 1949; Bridges, 1970; Petersen, 1976; Foth, 1984).

Quartz sands in non-glaciated terrains enable podzolization to be pronounced in moist warm, and even moist tropical climates. An example of this are the strikingly podzolized soils and associated highly acidic peats of the Atlantic Coastal Plain of the eastern United States which extend into the moist subtropical climate of Florida (Marbut, 1935; Joffe, 1949). Podzol soils and associated highly acidic peats are also widespread in the Amazon Basin and are developed from sandy deposits derived from granites and gneisses (Klinge, 1965; Sioli, 1975). Podzolized soils and peats analogous to those of the Atlantic Coastal Plain (Marbut, 1935; Joffe, 1949; Holzhey et al., 1975) also predominate on the sandy coastal deposits of coastal eastern Australia, going from relatively moist and cool Tasmania through the moist subtropical and tropical climates of Queensland (Bayley, 1964; Thompson, 1981; 1983; Thompson and Moore, 1984; Reeve et al., 1985).

Highly acidic podzolized soils and associated peats more typical of southern Scandinavia (Bergseth, 1977; Lag, 1979) and southeastern Canada (Clayton et al., 1977) exist in the recently-glaciated terrain of western Tasmania (Davies, 1965) and the recently-glaciated terrain of the moist, cool to temperate climates of the west coast of the South Island of New Zealand (Mclintock, 1960; Mew and Lee, 1981).

This worldwide distribution of highly acidic podzolized soils and 
associated peats is clearly delineated as soils with toxic levels of acidity on the world soil map of problem acid soils prepared by the Soil Geography Unit of the U.S. Department of Agriculture (Van Wambeke, 1976).

In conclusion, there are a number of locations identified above (the Amazon, Tasmania and much of the coastal plain of eastern Australia, and the west coast of the South Island of New Zealand) where "sensitive" watersheds occur in essentially the total absence of man-made acidic deposition (Galloway et al., 1982; Keene et al., 1983; Ayers and Gillett, 1984; Ayers et al., 1986; Verhoeven et al., 1987).

Florida is one location having "sensitive" watersheds where there is manmade acidic deposition but it is questioned as to whether deposition is acidic enough to result in acidification of surface waters (Linthurst et al., 1986; Reuss et al., 1987). 


\subsubsection{Recently-Glaciated "Sensitive" Watersheds}

Most of Tasmania's several thousand lakes were created by recent glaciation (ice sheets and mountain glaciers) and these lakes predominantly occur in the moist (40 to $100^{+}$in. ppt/yr) western half of Tasmania which is largely an unsettled wilderness (Davies, 1965; Buckney and Tyler, 1973). Many lakes in the drier east were formed by periglacial activity (Buckney and Tyler, 1973). Tasmania is over $26,000 \mathrm{mi}^{2}$; the main island being about 340 miles wide from west to east (from Cape Grim, a pristine background atmospheric monitoring site for the World Meteorological Organization, WMO (Ayers et al., 1986) to Eddystone Point) and about 350 from north to south (from Cape Grim to S.E. Cape).

There are corresponding west-to-east climatic, soil, and vegetational gradients across Tasmania. Highly acidic podzol soils and peats, and associated acidophilic vegetation occur in the moist and recently-glaciated terrain of the west (Davies, 1965; Buckney and Tyler, 1973).

The alternative hypotheses of acidification and the results of paleolimnological investigations predict that acidic surface waters will cooccur with the highly acidic, organic-rich soils and peats of the west. A surface water acidity gradient paralleling the soil acidity gradient is also predicted.

Buckney and Tyler (1973; Table 19) conducted a regional survey of 170 Tasmanian lakes and rivers: 75 of which are in the west; 54 in the mountainous, high rainfall southwest, and; 21 in the more moderate rainfall and less mountainous northwest. Buckney and Tyler (1973) report that the surveyed surface waters are representative of their respective, distinct 
Table 19. Some Chemical Parameters of the $17 \mathrm{pH}<5.0$ Surface Waters Found of 75 Surveyed in Western Tasmania by Buckney and Tyler (1973).

\begin{tabular}{|c|c|c|c|c|c|c|c|c|c|c|c|c|c|c|c|}
\hline \multirow[b]{2}{*}{ Sample } & \multirow[b]{2}{*}{$\mathrm{pH}$} & \multirow[b]{2}{*}{ Color } & \multirow[b]{2}{*}{$\mathrm{Na}$} & \multirow[b]{2}{*}{$\mathbf{K}$} & \multirow[b]{2}{*}{$\mathrm{Ca}$} & \multirow[b]{2}{*}{$\mathbf{M g}$} & \multirow[b]{2}{*}{$\mathrm{Cl}$} & \multirow{2}{*}{$\mathrm{SO}_{4}$} & \multicolumn{2}{|l|}{ Non-Marine } & \multirow[b]{2}{*}{ A } & \multirow{2}{*}{$\begin{array}{c}\text { Anion } \\
\text { Deficit }\end{array}$} & \multirow{2}{*}{$\mathrm{B} C_{\text {INPUT }}$} & \multirow[b]{2}{*}{$B C_{\text {OUTPUT }}$} & \multirow{2}{*}{$\begin{array}{l}\mathrm{Net} \\
\mathrm{H}^{+}\end{array}$} \\
\hline & & & & & & & & & $\mathrm{SO}_{4}$ & $\mathbf{M}$ & & & & & \\
\hline \multicolumn{16}{|l|}{ SOUTHWEST } \\
\hline 1 & 4.5 & 140 & 304 & 17 & 42 & 103 & 472 & 27 & -21 & 498 & 499 & -1 & 499 & 466 & 33 \\
\hline 2 & 4.5 & 160 & 283 & 15 & 60 & 100 & 460 & 32 & -15 & 490 & 492 & -2 & 492 & 458 & 34 \\
\hline 3 & 4.9 & 100 & 266 & 23 & 42 & 93 & 420 & 80 & 37 & 436 & 500 & -64 & 463 & 424 & 39 \\
\hline 4 & 4.2 & 280 & 239 & 24 & 13 & 23 & 315 & 33 & 1 & 362 & 348 & 14 & 347 & 299 & 48 \\
\hline 5 & 4.8 & 120 & 140 & 8 & 52 & 61 & 200 & 37 & 16 & 277 & 237 & 40 & 221 & 261 & -40 \\
\hline 6 & 4.8 & 200 & 152 & 13 & 60 & 83 & 324 & 35 & 2 & 324 & 359 & -35 & 357 & 308 & 49 \\
\hline 8 & 4.8 & 200 & 167 & 11 & 47 & 85 & 234 & 69 & 45 & 326 & 303 & 23 & 258 & 310 & -52 \\
\hline 9 & 4.8 & 60 & 153 & 9 & 39 & 53 & 244 & 23 & -2 & 270 & 267 & 3 & 267 & 254 & 13 \\
\hline 10 & 4.8 & 80 & 189 & 9 & 33 & 69 & 271 & 27 & -1 & 316 & 298 & 18 & 298 & 300 & -2 \\
\hline 11 & 4.5 & 100 & 145 & 3 & 37 & 73 & 241 & 27 & 2 & 290 & 268 & 22 & 266 & 258 & 8 \\
\hline 12 & 4.7 & 100 & 118 & 21 & 35 & 58 & 248 & 21 & -4 & 252 & 269 & -17 & 269 & 232 & 37 \\
\hline 28 & 4.3 & 140 & 313 & 19 & 42 & 103 & 472 & 27 & -21 & 527 & 499 & 28 & 499 & 477 & 22 \\
\hline 30 & 4.5 & 100 & 129 & 8 & 26 & 44 & 211 & 19 & -3 & 239 & 230 & 9 & 230 & 207 & 23 \\
\hline 31 & 4.8 & 120 & 121 & 5 & 24 & 74 & 220 & 23 & 0 & 240 & 243 & -3 & 243 & 224 & 19 \\
\hline 32 & 4,9 & 150 & 154 & $\underline{10}$ & $\underline{45}$ & 74 & 287 & 48 & 19 & $\underline{295}$ & 335 & -40 & $\underline{316}$ & $\underline{283}$ & 33 \\
\hline MEAN & 4.6 & 137 & 192 & 13 & 40 & 73 & 308 & 35 & 4 & 343 & 343 & 0 & 335 & 317 & 18 \\
\hline \multicolumn{16}{|l|}{ NORTHWEST } \\
\hline 5 & 4.8 & 280 & 566 & 105 & 283 & 400 & 842 & 320 & 234 & 1370 & 1162 & 208 & 928 & 1354 & -426 \\
\hline 21 & 4.8 & 560 & 610 & 105 & 55 & 277 & 1430 & 115 & -32 & 1063 & 1545 & -482 & 1545 & 1047 & 498 \\
\hline
\end{tabular}

Color - Platinum-cobalt units, PCU.

Non-marine $\mathrm{SO}_{4}$ - surface water $\mathrm{SO}_{4}-\mathrm{SO}_{4 \text { marine }} . \mathrm{SO}_{4 \text { marine }}$ is estimated by the $\mathrm{SO}_{4} / \mathrm{Cl}$ equivalent ratio of seawater, 0.1026. Negative values mean that net watershed retention of $\mathrm{SO}_{4}$ exceeds watershed plus estimated marine input.

$\mathrm{M}-\mathrm{H}^{+}+\mathrm{Na}^{+}+\mathrm{K}^{+}+\mathrm{Ca}^{2+}+\mathrm{Mg}^{2+}$.

$\mathrm{A}-\mathrm{Cl}^{*}+\mathrm{SO}_{4}^{2-}$

Anion Deficit - $M$ - A. Negative values are anion excesses.

$\mathrm{BC}_{\text {INPIT }}$ - Total ionic concentration of base cations $\left(\mathrm{Na}^{+}+\mathrm{K}^{+}+\mathrm{Ca}^{2+}+\mathrm{Mg}^{2+}\right.$ ) in surface water is estimated to be

equivalent to seaspray input. Seaspray input is estimated by assuming that all $\mathrm{Cl}^{-}$is due to seaspray and that all $\mathrm{SO}_{4}{ }^{2-}$ present in surface waters up to the $\mathrm{SO}_{4} / \mathrm{Cl}$ equivalent ratio of 0.1026 (that of seawater) is due to atmospheric inputs of seaspray.

$\mathrm{BC}_{\text {OUTPU }}$ - watershed output of base cations, which is defined as the total ionic concentration of base cations in surface waters.

Net $\mathrm{H}^{+}$- NET ION EXCHANGE STRONG ACID PRODUCTION - $\mathrm{BC}_{\text {INPUT }}$ - $B C_{\text {OUTPUT }}$. Values of $B C_{\text {INPUT }}-\mathrm{BC}_{\text {OUTPUT }} 0$ are assumed to represent soil and plant ion exchange production of strong acid, principally $\mathrm{HCl}$. Values of $B C_{I N P U T}-B_{O U T P U T} 0$ are assumed to represent net watershed production of $\mathrm{BC}_{-} \mathrm{SO}_{4}{ }^{2-}, \mathrm{BC}-\mathrm{RCOO} 0^{\circ}$, and $\mathrm{BC}-\mathrm{HCO}_{3}{ }^{\circ}$, i.e., in other words, production of basic non-marine sulfates, humates, and alkalinity exceeds watershed conversion of seasalts to strong mineral acidity. This definition of NET ION EXCHANGE STRONG ACID PRODUCTION assumes that watershed retention of marine SO, converts input of $\mathrm{BC}-\mathrm{SO}_{4 \text { marine }}$ to $\mathrm{BC}-\mathrm{HCO}_{3}{ }^{-}$. By this definition, because of watershed retention of marine $\mathrm{SO}_{4}$, there can be net watershed retention of base cations without net ion exchange production of strong acidity. 
surface water provinces of Tasmania (Buckney and Tyler, 1973).

Clearly, in terms of numbers of surface waters sampled, the numerous glacial lakes and streams of the wilderness west are underrepresented in favor of the more accessible surface waters of the drier and more settled east.

Overall, $10 \%$ of the surveyed Tasmanian surface waters have $\mathrm{pH}$ values less than 5.0 (Buckney and Tyler, 1973; Table 19). There are no $\mathrm{pH}<5.0$ surface waters reported from the east. However, in the glaciated and mountainous southwest, $28 \%$ of sampled surface waters are $\mathrm{pH}<5.0$, and $9.5 \%$ are $\mathrm{pH}<5.0$ in the less mountainous and somewhat drier northwest (Buckney and Tyler, 1973; Table 19). In the southwest, $37 \%$ of the sampled surface waters are pH $<5.5$ (Buckney and Tyler, 1973).

Concentrations of DOC or TOC are not reported by Buckney and Tyler (1973), however, color (Pt units) is. All pH<5.0 Tasmanian waters surveyed have color $\geq 60$ Pt units (Buckney and Tyler, 1973; Table 19). Thus, highly acidic $(\mathrm{pH}<5.0)$ Tasmanian surface waters can be subjectively described as humic colored (Krug et al., 1985).

Iimnological investigations of highly acidic, southwest Tasmanian waters indicate that they have a sparse fauna and flora typical of acid-stressed aquatic ecosystems (Bayley, 1964; 1973; King and Tyler, 1981).

In most pH<5.0 Tasmanian watersheds, ion exchange processes appear to play an important complementary role in acidification. Ion exchange appears to often result in the near-complete removal of watershed-produced alkalinity through strong acid titration (Table 19). Thus, ion exchange processes enable organic acids to have the apparent primary role in acidification of surface waters by removing most, or all, alkalinity so that organic acids can 
impart free $\mathrm{H}^{+}$to water rather than simply use $\mathrm{H}^{+}$to titrate alkalinity. There appears to be a net release of strong acidity to a number of $\mathrm{pH}<5.0$ surface waters by ion exchange processes (Table 19). For a few waters, the amount of strong acid production appears to be great enough to result in anion excesses (Table 19), which is indicative of unaccounted for ions, possibly ionic metals dissolved by strong acid (Chapter 3.5).

In conclusion, acidic Tasmanian surface waters are generally acidified by a mix of weak and strong acids (Table 19) like the waters in the "clean rain" experimental Risdalsheia mini-catchment in southermmost Norway (Table 17; Wright, 1987; Wright et al., 1988) and Jamieson Creek in British columbia, which is said not to be receiving man-made acidic deposition (Driscoll et al., 1988b). Both the Risdalsheia experiment and the comparison of Jamieson Creek with Hubbard Brook, New Hampshire (Driscoll et al., 1988b) support the alternative hypotheses of acidification (Chapter 3.7.2.2; Table 17) in that the principal effect of high rates of acidic deposition is not to increase the acidity of water but to cause a qualitative shift in the nature of water acidity, i.e., acidic deposition transforms acidic humic water to acidic sulfate water and acidic deposition increases watershed leaching of bases and, thereby, masks natural strong acid production.

The "sensitive" watersheds of Tasmania have a proportion of highly acidic surface waters that favorably compare with percentages reported for "sensitive" watersheds receiving high rates of acidic deposition. For example, excepting Florida, the NSWS ${ }^{1}$ found that $3.7 \%$ of lakes sampled in

1.) - The NSWS survey may not be directly comparable with other surveys of "sensitive" watersheds because (to the best of my knowledge) it is the only survey published that reportedly has a statistically-valid basis (Kanciruk et al., 1986) for developing population estimates of acidic surface waters. 
"sensitive" watersheds in the eastern United States (the upper Midwest and Northeast) have pH values less than 5.0 (Kanciruk et al., 1986). For recently-glaciated terrain, the NSWS found that the Adirondacks have the highest percentage of $\mathrm{pH}<5.0$ surface waters, $10 \%$ are $\mathrm{pH}<5.0$. However, the percentage of $\mathrm{pH}<5.0$ lakes and ponds in the Adirondacks is likely to be higher than $10 \%$ because NSWS excluded impoundments with areas of less than 4 ha. Smaller impoundments tend to be more acidic than larger ones (Malanchuk and Turner, 1987; Krug, 1988).

Survey of $226 \mathrm{small}$ New England headwater lakes and streams located in "especially sensitive" watersheds found that $8.4 \%$ have $\mathrm{pH}<5.0$ (Haines and Akielaszak, 1983). A survey of 155 small headwater lakes in southern Norway found that $18 \%$ have $\mathrm{pH}<5.0$ (Wright et al., 1977).

Gorham's (1957) survey of Nova Scotian lakes reported 43\% having pH values less than 5.0. The canadian national acid rain lake survey reports that 47.3\% of Nova Scotian lakes surveyed are pH<4.7 (Kelso et al., 1986), easily the highest percentage reported for a region in North America, with Florida coming in second (Kanciruk et al., 1986; Kelso et al., 1986). Curiously neither Florida (Reuss et al., 1987) nor Nova Scotia (Underwood et al., 1987) receive high rates of acidic deposition.

These Nova Scotian and Florida surface-water data merit further comment. The Florida region of the NSWS may not to be receiving acidic deposition severe enough $(\mathrm{pH}>4.7)$ to result in chronic surface-water acidification (Linthurst et al., 1986; Reuss et al., 1987) and the mean annual precipitation $\mathrm{pH}$ for Nova Scotia ranges from 4.6 to about 4.9 across the Province (Underwood et al., 1987). Gorham's (1957) lakes may not have been receiving acidic deposition at all (Likens et al., 1979; Watt et al., 1979; 
National Research Council, 1981; Havas et al., 1984). Indeed, Henriksen (1980) reported that he used early post World War II Nova Scotia and Georgia surface waters as waters not receiving acidic deposition in order to develop his predictive surface water acidification nomograph.

That the highest percentages of highly acidic lakes in North America exist in relatively low or no acidic deposition areas, by itself, suggests the possibility that, contrary to the predictions of acidification theory, highly acidic surface waters can be a natural phenomenon of these regions.

Returning to the Tasmanian surface waters, the highly acidic surface waters in "sensitive" watersheds of Tasmania occur in percentages that compare favorably to percentages reported for similar "sensitive" regions receiving high rates of acidic deposition. This finding does not support the basic premise of acidification theory that such proportions of highly acidic surface waters are necessarily due to acidic deposition. However, this finding does support the basic premise of the alternative hypotheses of acidification (and the results of paleolimnology) that highly acidic surface waters in such "sensitive" regions were relatively common prior to acidic deposition. The nature of acidity in highly acidic Tasmanian surface waters supports the other fundamental premise of the altermative hypotheses of acidification that the principal effect of acidic deposition is the qualitative shift in the nature of water acidity rather than acidification per se.

The survey of Tasmanian surface waters supports the following predictions of the alternative hypotheses of acidification:

1.) - acidic surface waters naturally co-occur with highly acidic, organic-rich soils and peats typical of many "sensitive" watersheds of eastern North America and northern Europe. Natural soil acidity gradients can result in natural surface water 
acidity gradients.

2.) - the qualitative and quantitative nature of acidity in Tasmanian waters supports the hypothesis (and results of paleolimnology) that acidification of surface waters by acidic deposition is superimposed upon natural processes of acidification and that most currently acidic surface waters were acidic in preindustrial times. The principal effect of acidic deposition on currently acidic surface waters is a qualitative shift in the nature of acidity resulting in the transformation of waters naturally acidified principally by weak organic acids to waters acidified principally by strong sulfuric acid with relatively little change in $\mathrm{pH}$. Also, acidic-deposition-induced increased leaching of mineral base cations $\left(\mathrm{Ca}^{2+}+\mathrm{Mg}^{2+}+\mathrm{K}^{+}+\mathrm{Na}^{+}\right)$can mask the natural production of strong acid by soil and plant ion exchange that may co-occur with organic acidity in naturallyacidified waters.

A second area of recently-glaciated terrain having highly acidic podzol soils and associated peats typical of many "sensitive" watersheds of eastern North America and northern Europe is the west coast of the South Island of New Zealand. Verhoeven et al. (1987) report that precipitation chemistry of this area is remarkably clean, similar to that of the wMO site at Cape Grim in Tasmania. Precipitation $\mathrm{pH}$ is 5.6-5.7. Land airmass storms produce exceedingly dilute precipitation $(1-2 \mathrm{us} / \mathrm{cm})$ and seastorms contain elevated levels of seasalts (concentrations of $\mathrm{Cl}^{-}$in coastal precipitation from seastorms range $10-165 \mathrm{ueq} / \mathrm{L})$. Fog and cloud water have essentially the same chemistry as rain, e.g.,pH 5.6, indicating an amazingly pristine atmospheric environment (Verhoeven, 1987). In May 1988, Dr. John Adams (Lincoln college, Canterbury, New Zealand) and I collected precipitation from a land airmass storm on the west coast (along with samples of local surface waters). It had a pH of 5.67 and a conductivity of $1.55 \mathrm{us} / \mathrm{cm}$, being little more than distilled water having dissolved $\mathrm{CO}_{2}$. West coast precipitation is apparently even lacking simple organic acids that are present and acidify precipitation to $\mathrm{pH}-5$, or less, at some other pristine sites (Keene et al., 
1983) .

Highly acidic surface waters (other than those derived from volcanic waters of the North Island) in New Zealand occur in considerable numbers (Jolly and Brown, 1975; MCDowall and Eldon, 1980; Pearce and Griffiths, 1980; Collier and Winterbourn, 1987) under the Rimu and Rata forests of the west coast in association with the highly acidic, gley (imperfectly drained) podzols developed on the granites and glacial tills in Westland, west of the Alpine Fault of the South Island (Holloway, 1954; McLintock, 1960; Mew and Leamy, 1977; Mew and Iee, 1981). $\mathrm{pH}$ values as acidic as 3.3 have been reported, ostensibly due to humic acids (Jolly and Brown, 1975; McDowall and Eldon, 1980; Pearce and Griffiths, 1980; Collier and Winterbourm, 1987). However, comprehensive chemical analyses of these acidic waters appear to be absent from the published scientific literature.

Table 20 presents water chemistry data for 8 pH<5.0 streams and lakes sampled by Dr. John Adams of Lincoln College (Canterbury, New Zealand) and the author and analyzed by the central Analytical Laboratory (CAL) of the Illinois State Water Survey (ISWS). Generally, total concentration of base mineral cations is but little more (and in one case less) than expected from atmospheric input of seasalt. Often, watershed output of individual cations is less than estimated atmospheric input of seasalt. Acidification by organic acids is apparently enhanced by soil and plant ion exchange that produces enough $\mathrm{H}^{+}$by cation uptake to neutralize nearly all alkalinity produced by mineral weathering (Table 20).

The streams sampled commonly run in channels cut 4 to 8 feet deep in mineral, podzol soils. The podzol soil profiles are less than 2 feet thick (also see Mew and Lee, 1981). Thus, it was surprising to me that these 
Table 20. Water Chemistry Data for Some pH<5.0 Surface Waters of the West Coast of the South Island of New Zealand.

\begin{tabular}{|c|c|c|c|c|c|c|c|c|c|c|c|}
\hline SAMPLE & $\mathrm{pH}$ & $\begin{array}{c}\mathrm{DOC} \\
(\mathrm{mg} / \mathrm{L})\end{array}$ & H & $\mathbf{C a}$ & $\mathrm{Mg}$ & $\mathrm{Na}$ & $\mathrm{K}$ & $\begin{array}{l}\mathrm{Cl} \\
\mathrm{\mu eq} / \mathrm{L} \text { ) }\end{array}$ & $\mathrm{SO}_{4}$ & $\begin{array}{l}\text { ANION } \\
\text { DEFICIT }\end{array}$ & $\begin{array}{c}\text { NET ION EXCHANGE } \\
\text { STRONG ACID PRODUCTION }\end{array}$ \\
\hline \multicolumn{12}{|c|}{ SALTWATER STATE FOREST } \\
\hline Tunnel Creek & 4.53 & 14.31 & 29.5 & 25.9 & 41.0 & 139.1 & 5.8 & 129.7 & $<19$ & 92.6 & -63 \\
\hline $\begin{array}{l}\text { Unnamed Creek } \\
\text { (Darby Road) }\end{array}$ & 4.31 & 15.25 & 48.9 & 25.4 & 43.5 & 145.2 & 4.1 & 183.3 & 41.7 & 42.1 & 6.8 \\
\hline $\begin{array}{l}\text { Hinatua R., } \\
\text { South Br. } \\
\text { (Metal Pit Rd.) }\end{array}$ & 4.40 & 16.02 & 39.8 & 26.0 & 36.5 & 117.4 & 7.8 & 110.0 & $<19$ & 98.5 & -58.7 \\
\hline $\begin{array}{l}\text { Unnamed Tarn } \\
\text { (SSE of Mermaid } \\
\text { Peninsula) }\end{array}$ & 4.72 & 12.38 & 19.0 & 35.1 & 43.9 & 141.7 & 9.7 & 163.6 & $<19$ & 66.8 & -47.8 \\
\hline \multicolumn{12}{|c|}{ IANTHE STATE FOREST } \\
\hline $\begin{array}{l}\text { Unnamed stream } \\
\text { (Rooney's Tract) }\end{array}$ & 4.84 & 1.5 .22 & 14.4 & 67.7 & 45.5 & 73.3 & 4.2 & 124.1 & $<19$ & 62.0 & -47.6 \\
\hline $\begin{array}{l}\text { Pool } \\
\text { (Rooney's Tract) }\end{array}$ & 4.77 & 1.5 .96 & 16.9 & 60.1 & 47.6 & 139.1 & 19.2 & 149.5 & 35.4 & 98.0 & -81.8 \\
\hline \multicolumn{12}{|l|}{ NZMS $1550 / 51$ MAP } \\
\hline Okuku Reservoir & 4.87 & 7.64 & 13.4 & 39.2 & 35.0 & 123.0 & 4.5 & 155.1 & 35.4 & 24.6 & -11.2 \\
\hline Lake Mudgie & 4.77 & 7.56 & 16.9 & 21.1 & 29.6 & 109.6 & 4.2 & 121.3 & $<19$ & 41.4 & -24.2 \\
\hline \multicolumn{12}{|c|}{ 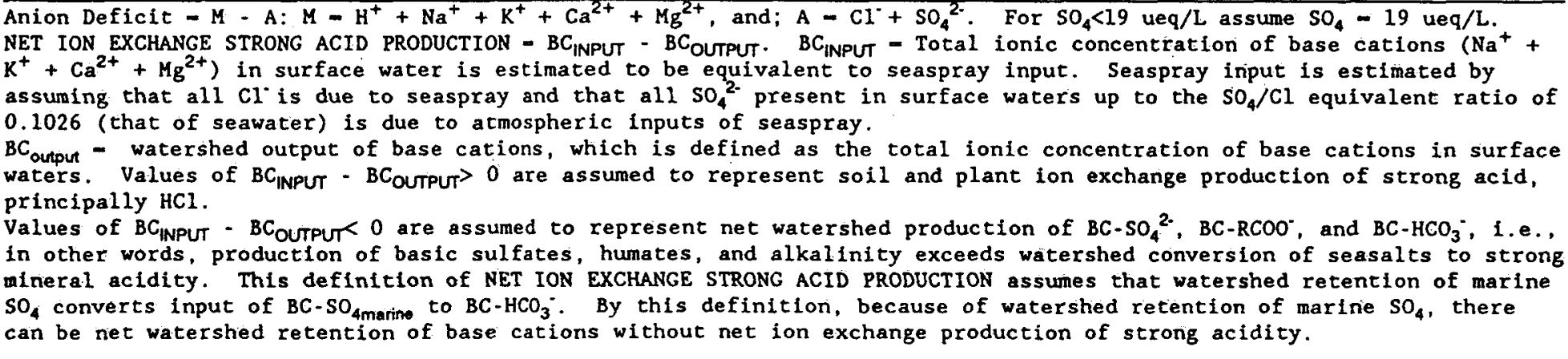 } \\
\hline
\end{tabular}


waters were highly acidic because of their intimate contact with weatherable mineral bases. However, water chemical analysis shows that these waters are poor in base mineral cations (Table 20). Apparently, acid cation exchange by the luxuriant growth of mosses and forest vegetation neutralizes most to all of the alkalinity produced by mineral weathering, thereby, enabling $\mathrm{H}^{+}$from organic acids to lower water $\mathrm{pH}$ rather than be consumed by alkalinity (Table 20).

This survey of acidic New Zealand surface waters is too limited to provide a quantitative estimate of proportion of acidic surface waters in this region of forested podzol soils. Nevertheless, my experience suggests that highly acidic surface waters are the rule rather than the exception on the forested, podzol soil landscapes of the west coast of the South Island of New Zealand.

It is my experience that going "blind" (without previous survey information) into "sensitive" regions of the Northeast in the hopes of finding highly acidic surface waters is very frustrating. But, in New zealand, we found highly acidic surface waters to be so common that shortly after our survey began, I no longer trusted the pH meter, the buffers, and its calibration because we could not find any waters that registered above pH 5.0. Therefore, we drove out to an area with considerable erosion, and found a river running through a deep ravine that must be receiving mostly deep and aged groundwater. The river's pH measured 7 . Faith restored, Dr. Adams and I continued about the survey. Field pH values were later found to be within \pm 0.1 of ISWS laboratory $\mathrm{pH}$ values.

Highly acidic surface waters are so common in the surveyed area of New Zealand that not only were many "blindly" found on the first day, but the entire trip's allotment of sample containers were used up on that first day. 
After that point the survey continued, but only measurements of pH were taken. Accordingly, I believe that the majority of surface waters derived from drainage of the forested, podzol soil landscapes of the west coast of the South island of New Zealand are $\mathrm{pH}<5.0$.

In conclusion, there appears to be exceptionally high percentages of highly acidic surface waters in recently-glaciated "sensitive" (mantled by highly acidic podzol soils and associated peats) watersheds in Australia and New Zealand not receiving man-made acidic deposition. That these naturally highly acidic surface waters are relatively common in "sensitive" watersheds, combined with the nature of their acidity strongly support the alternative hypotheses of acidification and results of paleolimnological investigations: most currently acidic surface waters were always acidic; acidification by acidic deposition is superimposed upon natural processes of acidification , and; the principal effect of acidic deposition on such surface waters has been the qualitative shift in the nature of acidity rather than acidification per se, as necessarily expounded by acidification theory. 


\subsubsection{Non-Glaciated "Sensitive" Watersheds}

NAPAP has not limited its surface water surveys to just recently-glaciated "sensitive" watersheds. Highly acidic lakes and streams have been found in non-glaciated "sensitive" watersheds of the eastern United States (NAPAP, 1984 ; 1987; Linthurst et al., 1986; Malanckuk and Turner, 1987).

However, review of the scientific literature shows that highly acidic surface waters also occur in non-glaciated "sensitive" watersheds not receiving acidic deposition. For example, Rosenqvist (1980) presented data showing that highly acidic $(\mathrm{pH}<5.0)$ clear and colored surface waters exist in the Amazon Basin in association with highly acidic soils. Furthermore, Rosenqvist (1980) cited that, nearly two centuries ago, Alexander von Humbolt described these waters as being nearly lifeless and having a sparse fauna and flora which is now recognized as being diagnostic of highly acidic waters. The 1984 cousteau documentary on the Amazon noted that natives call the highly acidic waters of the Amazon "rivers of hunger" because so little lives in them. The largest of these $\mathrm{pH}_{4}$ 's rivers is the Rio Negro, which is about the size of the Mississippi River.

Apparently highly acidic waters are the rule rather than the exception in the Rio Negro drainage basin (Klinge and Ohle, 1964; Junk, 1983), which is equivalent in size to a substantial portion of the United States. Such a distribution of highly acidic surface waters greatly exceeds that reported for any region receiving acidic deposition.

Rosenqvist's claim that pH less than 5.0 clearwaters naturally exist in the Amazon Basin is supported by evidence readily available in the scientific literature. A recent review of Amazon Basin water-chemistry data states, 
"clear-water brooks of the Tertiary 'Barreiras' ... are colorless and quite transparent, and have a pH from 4.5 to 4.9 " (Junk, 1983, p. 273). This sumary statement is based on over 100 stream survey observations. It is of further interest to note that unlike most waters which can be phosphorus limited, these Amazon waters contain so little $\mathrm{SO}_{4}{ }^{2-}$ that they can be both phosphorus and sulfur limited (Klinge and Ohle, 1964; Fittkau, 1964; Junk, 1983). It appears to be extremely unlikely that these Amazon clearwater, pH less than 5.0 streams are acidified by man-made deposition of $\mathrm{H}_{2} \mathrm{SO}_{4}$.

Nevertheless, subsequent to Rosenqvist's (1980) publication, there is a reported scientific consensus that clearwaters more acidic than predicted by carbonate chemistry (other than acid mine drainage) are necessarily the product of acidic deposition. Some examples of the reported consensus follow.

"Lakes and streams naturally acidified . . . . are always distinctly tea-colored, and can readily be distinguished from the clear-water lakes now undergoing acidification because of man's activities." (National Research Council, 1981, p. 152).

The Critical Assessment Review Papers (CARP), published by the U.S. EPA (1984) in regard to assessing the aquatic effects of acidic deposition states:

"SUMMARY -- ALTERNATIVE EXPIANATIONS FOR ACIDIFICATION. Certainly natural processes and land use changes can result in slightly acidic waters . . . . There is no evidence, however, that land use changes in areas not (emphasis added) receiving acidic deposition produce clear waters with $\mathrm{pH}^{\prime} \mathrm{s}$ much less than 5.5. . . . Thus natural acidification, or the return of a system to its natural state will not produce clearwater oligotrophic lakes with pH much less than 5.5" (U.S. EPA, 1984, p. 4-107).

Later on the CARP document concludes:

"It appears that regional acidification and episodic pH depressions $(\mathrm{pH}<5)$ in clearwater lakes and streams occur only in response to increased atmospheric deposition of strong acid." U.S. EPA, 1984, p. 4-168). 
Apparently, the Critical Assessment Review Papers (U.S. EPA, 1984) ignore data reported in the scientific literature (e.g., Klinge and Ohle, 1964; Fittkau, 1964; Siolị, 1975; Junk, 1983) and by Rosenqvist (1980) and do not consider the possibility that highly acidic humic (colored) waters may have been transformed to highly acidic (clear) sulfate waters by acidic deposition (Krug and Frink, 1983a, b).

Subsequently, the National Surface Water Survey (NSWS) found that clear and colored highly acidic $(\mathrm{pH}<5.0)$ lakes are more common in Florida and southern Georgia (collectively known as the Florida region of the NSWS) than anywhere else in the eastern United States, including the Adirondacks (Kanciruk et al., 1986). Although Florida is certainly not a remote area, mean precipitation $\mathrm{pH}$ for the region is greater than 4.6 and Linthurst et al. (1986) report that the existence of these lakes cannot be explained entirely in terms of acidification by acidic deposition. Of over 1600 lakes examined by the NSWS in "sensitive" regions in the eastern U.S., only $75 \mathrm{pH}<5.0$ lakes were found (4.7\%). Of these 75 lakes, 25 were found in Florida of only about 150 lakes sampled there $(16.6 \%$ of lakes surveyed are $\mathrm{pH}<5)$. Despite lower rates of acidic deposition, the proportion of highly acidic lakes per sampled lakes is five times greater in Florida (16.6\%) than in the rest of the "sensitive" areas surveyed by the NSWS in the eastern U.S. (3.7\%) .

NAPAP's Interim Assessment claimed that acidic deposition contributed significantly to acidification of lakes in the upper Midwest and the Northeast, but did not make such a claim for the acidic Florida lakes (Malanchuk and Turner, 1987).

In the Nature review article, "Chemical Processes Governing Soil and Water Acidification", Reuss et al. (1987) claimed that "acidified freshwaters are $3-188$ 
largely confined to areas within the pH 4.7 isoline" of North America and Europe. The North America pH 4.7 isoline excluded all of the NSWS's Florida sampling region (Kanciruk et al., 1986). Reuss et al. (1987) asserted that anion indicates source of acidity, " 'Show me your anion and I will show you who you are' ". Thus, they acknowledged that:

"Natural organic acids can cause acidic $(\mathrm{pH}<5.0)$ surface waters in regions not receiving acidic deposition, for example, in bog waters in central Canada 39 , several lakes in Florida 40 , and rivers in the Amazon region 41 . Such waters are usually highly colored." (Reuss et al.,1987).

But, low DoC, clearwaters more acidic than pH 5.0 (exemplified by 2-8 mg DOC/L Adirondack waters cited by Reuss et al. (1987)) as well as the presence of ionic metals (such as aluminum) are considered by Reuss et al. (1987) to be the result of acidic $\left(\mathrm{H}_{2} \mathrm{SO}_{4}\right)$ deposition. As we have already seen, however, there are numerous $\mathrm{pH}<5.0$ clearwaters in both the Amazon and Florida. Table 21 shows that about half (12 of 25) of $\mathrm{pH}<5.0$ NSWS Florida lakes have DOC concentrations less than or equal to those values cited by Reuss et al. (1987) as being clearwaters acidified by acidic $\left(\mathrm{H}_{2} \mathrm{SO}_{4}\right)$ deposition (e.g., Adirondack lakes). Furthermore, $\mathrm{Cl}^{-}$, not $\mathrm{SO}_{4}{ }^{2-}$, appears to be the dominant inorganic anion in the highly acidic Florida surface waters (Table 21). Additionally, despite relatively low rates of acidic $\left(\mathrm{H}_{2} \mathrm{SO}_{4}\right)$ deposition, anion excess values (an indicator of ionic metals) in some Florida clearwaters is appreciable with lake 3B2-085 having the highest anion excess of the entire NSWS data set (Kancinuk et al., 1986; Table 21). Despite the inaccurate portrayal of highly acidic Florida NSWS lakes (Reuss et al., 1987), the importance of acidic deposition for these lakes can be controversial. One means by which this question may be resolved is by examination of surface waters of similar watersheds that exist in the absence of acidic deposition. 
Table 21. Some Chemical Parameters of the $25 \mathrm{pH}<5.0$, found in the 150 Lakes of the "Florida" Sampling Region of the NSWS.

\begin{tabular}{|c|c|c|c|c|c|c|c|c|}
\hline $\begin{array}{l}\text { NSWS Lake } \\
\text { ID No. }\end{array}$ & Closed pH & ANC & Color/DOC & $\mathrm{SO}_{4}$ & $\mathrm{Cl}$ & M & $\mathrm{A}$ & $A-M$ \\
\hline $3 B 1-027$ & 4.81 & -23.1 & $20 / 0.94$ & 82.2 & 112.3 & 195.4 & 197.1 & 1.7 \\
\hline $3 \mathrm{~B} 1-036$ & 4.78 & -28.4 & $5 / 1.35$ & 76.4 & 145.0 & 239.6 & 225.0 & -14.6 \\
\hline $3 B 1-057$ & 4.34 & -58.7 & $225 / 20.18$ & 25.4 & 137.1 & 274.0 & 167.3 & -106.7 \\
\hline $3 B 1-067$ & 4.54 & -37.3 & $300 / 36.91$ & 67.7 & 349.8 & 674.1 & 436.1 & -238.0 \\
\hline $3 B 1-073$ & 4.57 & -36.7 & $25 / 5.39$ & 197.2 & 274.2 & 469.4 & 473.4 & 4.0 \\
\hline $3 B 1-077$ & 4.66 & -32.5 & $5 / 0.38$ & 125.8 & 187.0 & 314.0 & 315.6 & 1.6 \\
\hline $3 B 1-090$ & 4.41 & -51.4 & $25 / 1.14$ & 111.0 & 149.5 & 248.2 & 262.5 & 14.3 \\
\hline $3 B 1-105$ & 4.45 & -46.1 & $5 / 0.29$ & 193.4 & 155.2 & 345.2 & 350.1 & 4.9 \\
\hline $3 B 1-106$ & 4.72 & -30.6 & $10 / 0.39$ & 204.9 & 154.6 & 337.2 & 361.2 & 24.0 \\
\hline $3 B 1-140$ & 4.87 & -23.8 & $5 / 1.60$ & 52.7 & 53.0 & 111.2 & 108.8 & -2.4 \\
\hline $3 \mathrm{~B} 2-001$ & 4.06 & -116.9 & $200 / 35.10$ & 3.1 & 161.6 & 291.6 & 166.1 & -125.5 \\
\hline $3 B 2-003$ & 4.33 & -62.7 & $150 / 25.90$ & 7.8 & 155.4 & 271.5 & 165.1 & -106.4 \\
\hline $3 B 2-005$ & 4.01 & -127.2 & $200 / 34.02$ & 3.0 & 172.9 & 315.4 & 177.0 & -138.4 \\
\hline $3 B 2-006$ & 4.05 & -122.1 & $225 / 38.44$ & 4.7 & 177.8 & 304.0 & 177.8 & -126.2 \\
\hline $3 B 2-010$ & 4.08 & -113.4 & $200 / 40.56$ & 6.2 & 196.6 & 375.4 & 204.4 & -171.0 \\
\hline $3 \mathrm{~B} 2-011$ & 3.96 & -148.8 & $200 / 38.44$ & 12.8 & 225.7 & 391.4 & 240.1 & -151.3 \\
\hline $3 B 2-027$ & 4.76 & -23.3 & $50 / 3.99$ & 226.9 & 332.9 & 568.4 & 565.9 & -2.5 \\
\hline $3 B 2-085$ & 4.42 & -46.1 & $5 / 0.96$ & 191.8 & 227.7 & 324.8 & 421.0 & 96.2 \\
\hline $3 B 2-087$ & 3.81 & -209.1 & $300 / 48.22$ & 10.5 & 140.8 & 315.2 & 152.5 & -162.7 \\
\hline $3 B 2-093$ & 3.86 & -178.9 & $225 / 43.02$ & 4.1 & 202.3 & 366.0 & 207.7 & -158.3 \\
\hline $3 B 2-100$ & 4.04 & -133.1 & $200 / 35.68$ & 6.9 & 179.7 & 331.8 & 187.9 & -143.9 \\
\hline $3 B 2-103$ & 4.18 & -87.0 & $175 / 31.08$ & 3.8 & 147.5 & 276.8 & 152.5 & -124.3 \\
\hline $3 B 3-002$ & 4.64 & -28.9 & $100 / 11.34$ & 27.5 & 96.8 & 178.7 & 126.2 & -52.5 \\
\hline $3 B 3-133$ & 4.76 & -26.2 & $5 / 3.93$ & 32.1 & 53.9 & 103.2 & 87.7 & -15.5 \\
\hline $3 B 3-176$ & 4.84 & -23.9 & $20 / 4.05$ & 31.4 & 76.2 & 128.6 & 110.2 & -18.4 \\
\hline
\end{tabular}

Data from Kanciruk et al., 1986.

Units are ueq/L except for: pH; color (Platinum-cobalt units, PCU), and; dissolved organic carbon ( $\mathrm{DOC}=\mathrm{mg} / \mathrm{L}$ ).

$\mathrm{A}=\mathrm{SO}_{4}^{2-}+\mathrm{HCO}_{3}^{-}+\mathrm{Cl}^{-}+\mathrm{NO}_{3}^{-}+\mathrm{F}^{-}$

$\mathrm{M}=\mathrm{H}^{+}+\mathrm{Ca}^{2+}+\mathrm{Mg}^{2+}+\mathrm{Na}^{+}+\mathrm{K}^{+}+\mathrm{NH}_{4}^{+}$.

A-M equals anion excess. 
Podzolized soils and peats analogous to those predominating the Atlantic Coastal Plain of the eastern United States (Marbut, 1935; Joffe, 1949; Holzhey et al., 1975) also predominate the sandy coastal plain of eastern Australia (Bayley, 1964; Thompson, 1981; 1983; Thompson and Moore, 1984; Reeve et al., 1985).

Australia has three lake districts: Tasmania, the western volcanic plains of Victoria, and the coastal plain, particularly Frazier Island (Bayley et al., 1975). The Victoria lake district does not represent "sensitive" watersheds because of base-rich, volcanic landscape.

Frazier Island appears to be a reasonable control to compare with Florida NSWS surface waters because of their similarity in soils and climate. Frazier Island is reported to be the largest sand island in the world, 160 $\mathrm{km}^{2}, 61.8 \mathrm{mi}^{2}$ (Bayley et al., 1975), and is located in Queensland. Surface waters, soils and geology of Frazier Island are essentially a continuum of the coastal plain from which it is but narrowly separated (Thompson, 1981; 1983; Thompson and Moore, 1984; Reeve et al., 1985). It is located within several miles of Cooloola National Park-Noosa River Area. Frazier Island and the Cooloola-Noosa Area are subtropical and moist, lying $25^{\circ}$ to $26^{\circ}$ south latitude as compared to $-30^{\circ}$ north latitude for northern Florida.

There is a general correlation between soil acidity and surface water acidity of the Australian coastal plain. Soils of the western coastal plain that abut the Pacific Ocean tend to be youngest, most disturbed and least acidic. Soils of the eastern drainages tend to be less disturbed, more mature and the most acidic (Thompson, 1981; 1983; Thompson and Moore, 1984; Reeve et al., 1985). Little and Roberts (1983) report that chemical analyses for 77 stream waters show that the mean $\mathrm{pH}$ of streams draining the eastern 
portion of Frazier Island have a mean $\mathrm{pH}$ of 5.0 and the streams draining the western portion have a mean $\mathrm{pH}$ of 5.5. Similar relationships between soil development, disturbance, and acidity of surface waters also have been consistently reported for other areas of the Australian coastal plain (Jennings, 1957; Bayley, 1964; Bayley et al., 1975; Timms, 1982; Reeve et al., 1985).

Little and Roberts (1983) developed an input/output budget which shows that less $\mathrm{K}$ and $\mathrm{Ca}$ is exported from Frazier Island watersheds than is being deposited in precipitation. They also report that more $\mathrm{Na}$ is being exported and that the precipitation input/stream output of $\mathrm{Mg}$ is about equal. However, incomplete chemical analysis, namely no determination of $\mathrm{SO}_{4}{ }^{2-}$ by either Little and Roberts (1983) or Bayley (1964; Table 22) does not enable development of estimated net ion exchange strong acid production. Nevertheless, cation $/ \mathrm{Cl}^{-}$ratios indicate that concentrations of various cations are often less than estimated seaspray input (Table 22), which support the data of little and Roberts (1983) and suggest strong acid production by natural ion exchange processes.

Frazier Island has 30 main lakes that are named, and numerous (generally smaller) lakes that are not (Bayley et al., 1975). Little and Roberts (1983) report that the mean $\mathrm{pH}$ of 11 main lakes that they have analyzed is $\mathrm{pH}=4.9$. Two studies (Bayley, 1964; Bayley et al., 1975) report a variety of chemical and physical factors for 19 of the 30 major lakes (plus one minor, unnamed lake and two streams) of Frazier Island, including pH (Table 22). The largest lake, Lake Boemingen, has a surface area of $1 \mathrm{mi}^{2}$ (which by itself is $1.6 \%$ of the total area of Frazier Island) and a pH of 4.7 (Table 22). Overall, $79 \%$ of the main lakes of Frazier Island are $\mathrm{pH} \leq 5.0$ and $84 \%$ are 
Table 22. Some Physical and Chemical Data for Lakes in Frazier Island, Australia.

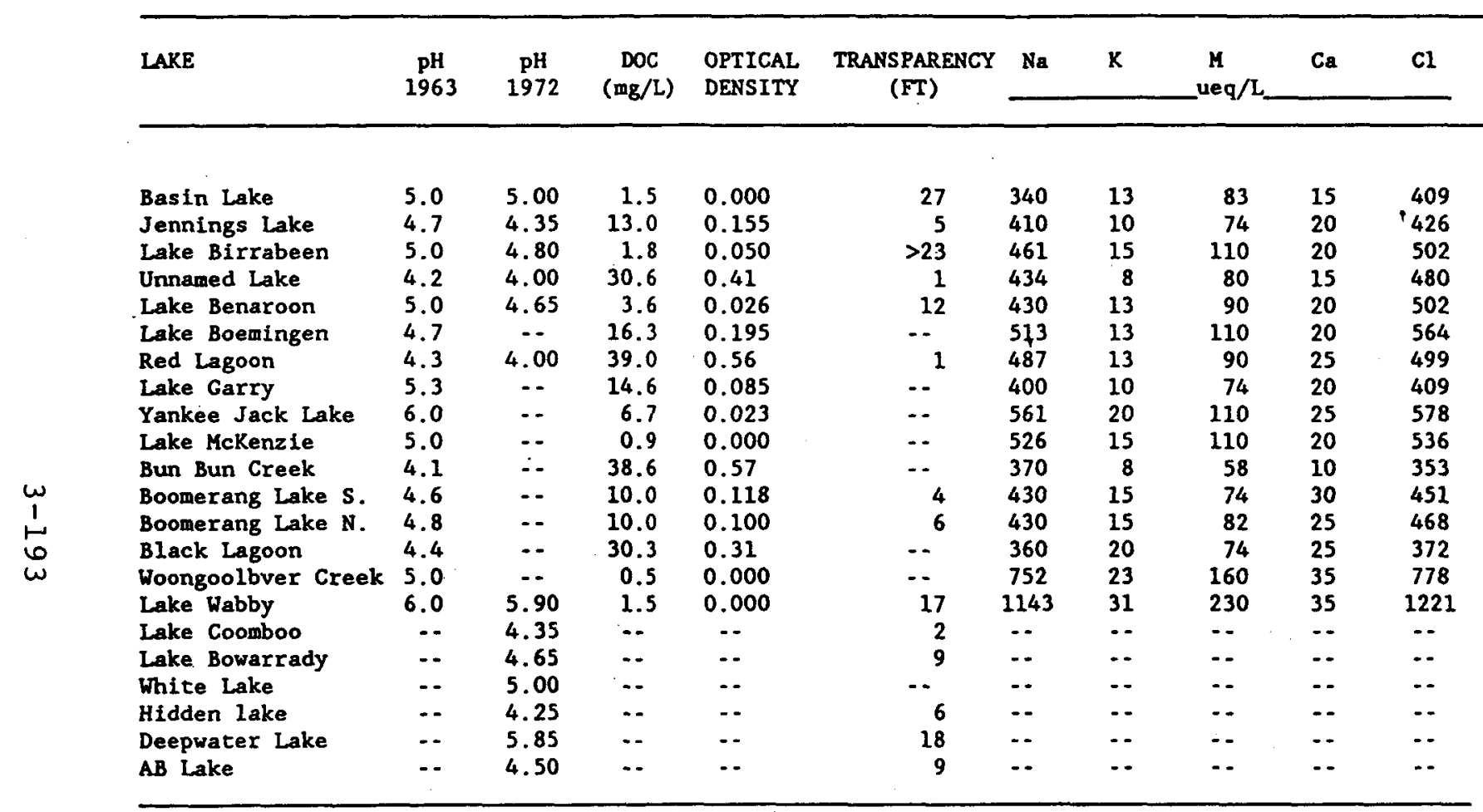

Data from Bayley (1964) and Bayley et al. (1975).

$\mathrm{mg} / \mathrm{L}$ DOC (dissolved organic carbon) $-\mathrm{mg} / \mathrm{L} \mathrm{O}_{2}$ consumed by permanganate oxidation. Permanganate oxidation is about 408 efficient in oxidation of DOC (Hutchinson, 1957, pp.879-880; Gjessing, 1976, pp.44), therefore, $\left(0_{2} / C\right) X(0.4)-(32 / 12)$ $X(0.4)-1$. Therefore, $1 \mathrm{mg} \mathrm{O}_{2}$ is consumed by permanganate oxidation per $\mathrm{mg}$ of $\mathrm{DOC}$.

Optical density determined at a wavelength of $385 \mathrm{mu}$. An optical density of 0.000 is that of the distilled water blank used by Bayley (1964). Accordingly, a number of acidic, low DOC Frazier Island lakes have the transparency and color of pure water, i.e., they are absolutely colorless.

Transparency - secchi disk transparency. 
$\mathrm{pH}<5.5$ (Table 22). The existence of the few $\mathrm{pH}>5.5$ lakes appears to be related to disturbance (Bayley, 1964; Bayley et al., 1975), as is also indicated by the relationships between landscape and surface-water chemistry at the nearby Cooloola-Noosa Area (Reeve et al., 1985).

Reported concentrations of DOC for acidic waters of Frazier Island range from $0.5 \mathrm{mg} / \mathrm{L}$ to $39 \mathrm{mg} / \mathrm{L}$ (Table 22). Overall, for main lakes with both reported values of $\mathrm{DOC}$ and $\mathrm{pH}, 23 \%$ of the $\mathrm{pH} \leq 5.0$ lakes have concentrations of DOC that are less than $2 \mathrm{mg} / \mathrm{L}$ and 31\% have concentrations of DOC low enough to be considered clearwaters by the criteria set forth by Reuss et al. (1987; Table 22). Highly acidic clearwaters appear to relatively common on Frazier Island, ranging from $18 \%$ to $25 \%$ of all main lakes based on the data in Table 22.

Water chemical analysis of lakes and streams of the Cooloola-Noosa Area (Table 23) are very similar to that of Frazier Island (Table 22). Highly acidic surface waters appear to be the rule rather than the exception. Reported concentrations of $\mathrm{DOC}$ for $\mathrm{pH} \leq 5.0$ Cooloola-Noosa waters range from 0.7 to $34 \mathrm{mg} / \mathrm{L}$ (Table 23). Organic acids appear to play the major role in surface water acidity. However, there is a sizeable minority of acidic clearwaters apparently acidified by strong mineral acid (HCl) with little or no anion deficit (or even anion excess) and low concentrations of DOC (Table 23). Ion exchange processes appear to play an important complementary role in acidification of even highly colored, organic-rich surface waters by the often near-complete removal of watershed-produced alkalinity through strong acid titration, thus, enabling organic acids to acidify water rather than titrate alkalinity. Often, concentrations of individual cations are less than estimated from inputs of seaspray alone (Table 23). If it were not for 
Table 23. Water Chemistry Data For Cooloola-Noosa Surface Waters.

\begin{tabular}{|c|c|c|c|c|c|c|c|c|c|c|c|c|c|}
\hline & & & Colior & DOC & & & & & & & Non-Mar & le ANION: & $\mathrm{Net}$ \\
\hline SITE & $\mathbf{n}$ & $\mathrm{pH}$ & (PCU) & $(\mathrm{mg} / \mathrm{L})$ & $\mathrm{Ca}$ & $\mathrm{Mg}$ & $\mathrm{Na}$ & $\mathrm{k}$ & Cl & $\mathrm{SO}_{4}$ & $\mathrm{SO}_{4}$ & DEFICIT & $\mathrm{H}^{+}$ \\
\hline \multicolumn{14}{|l|}{ LAKES AND PONDS } \\
\hline Lake Freshwater & 5 & 6.1 & 7 &.- & 30 & 170 & 750 & 25 & 880 & 100 & 10 & -1 & -5 \\
\hline W41 & 1 & 4.2 & 185 & $\cdots$ & 60 & 80 & 370 & 10 & 460 & $<20$ & -27 & 103 & -60 \\
\hline W42 & 2 & 5.0 & 9 & $\cdots$ & 40 & 140 & 540 & 30 & 680 & 80 & 30 & -3 & 0 \\
\hline Lake Coolamera & 5 & 5.0 & 71 & - & 20 & 90 & 420 & 9 & 490 & $<20$ & -30 & 46 & -29 \\
\hline W44 & 2 & 4.4 & 178 & -. & 30 & 80 & 330 & 15 & 380 & 20 & -19 & 137 & -55 \\
\hline Brackish Lagoon & 1 & 5.0 & 131 & $-\cdot$ & 30 & 70 & 340 & 15 & 350 & $<20$ & -16 & 99 & -85 \\
\hline Broutha Waterhole & 3 & 4.2 & 256 & -. & 40 & 180 & 840 & 27 & 970 & 190 & 90 & 84 & -17 \\
\hline Lake Poona & 5 & 4.6 & 54 & -. & 10 & 90 & 370 & 14 & 420 & 30 & -13 & 61 & -34 \\
\hline Lake Como & 1 & 5.1 & 6 & -- & 170 & 400 & 1420 & 60 & 1830 & 300 & 112 & 32 & -32 \\
\hline \multicolumn{14}{|l|}{ SELECTED STREAMS } \\
\hline Frankis Gulch & 9 & 5.2 & 4 & .. & 23 & 117 & 541. & 17 & 630 & 63 & -2 & 7 & -5 \\
\hline$\star$ & 1 & 5.24 & $\cdots$ & 1.60 & 21 & 122 & 548 & 17 & 674 & 60 & $-\overline{9}$ & -30 & 26 \\
\hline Searys Creek & 9 & 5.0 & 21 & -. & 16 & 89 & 393 & 10 & 458 & 54 & 7 & 6 & -4 \\
\hline * & 1 & 4.84 & .. & 6.25 & 15 & 100 & 413 & 10 & 485 & 48 & -2 & 8 & -5 \\
\hline Bubbling Springs & 9 & 4.9 & 13 & -. & 135 & 680 & 3150 & 87 & 3760 & 373 & -13 & .77 & 81 \\
\hline ** & 1 & 4.89 & $\ldots$ & 0.73 & 93 & 470 & 1774 & 38 & 2310 & 177 & -60 & -107 & 112 \\
\hline W4 & 9 & 4.5 & 77 & .. & 18 & 90 & 395 & 9 & 477 & 11 & -38 & 58 & -24 \\
\hline$\star$ & 1 & 4.42 & -- & 13.05 & 15 & 106 & 430 & 10 & 488 & $<19$ & -31 & 89 & -54 \\
\hline Paleosol Creek & 3 & 3.8 & 215 & -. & 20 & 90 & 410 & $<10$ & 440 & 10 & -35 & 238 & -80 \\
\hline * & 1 & 3.98 & $\ldots$ & 34.34 & 16 & 92 & 430 & 5 & 480 & 29 & -20 & 139 & -34 \\
\hline
\end{tabular}

Data from Reeve et al. (1985). All units are $\mu$ eq/L unless otherwise stated.

* - samples analyzed at the Central Analytical Laboratory of the Illinois State Water Survey. Original data.

** - Bubbling Springs was not located. Therefore, a nearby, spring-fed clearwater stream was sampled.

Non-marine $\mathrm{SO}_{4}-$ surface water $\mathrm{SO}_{4}$ - $\mathrm{SO}_{4 \text { marine. }} \mathrm{SO}_{4 \text { marine }}$ is estimated by the $\mathrm{SO}_{4} / \mathrm{Cl}$ equivalent ratio of seawater, 0.1026 . Negative values for $\mathrm{SO}_{4 m a r i n e}$ indicate that net watershed retention of $\mathrm{SO}_{4}$ exceeds watershed plus estimated marine input. $\mathrm{M}-\mathrm{H}^{+}+\mathrm{NH}^{4+}+\mathrm{Na}^{+}+\mathrm{K}^{7}+\mathrm{Ca}^{2+}+\mathrm{Mg}^{2+}$ except for $\star$ data which is $\mathrm{M}-\mathrm{H}^{+}+\mathrm{Na}^{+}+\mathrm{K}^{+}+\mathrm{Ca}^{2+}+\mathrm{Mg}^{2+}$.

$\mathrm{A}=\mathrm{Cl}^{-}+\mathrm{SO}_{4}^{2 \cdot}+\mathrm{NO}_{3}$.

Anion Deficit - M - A. Negative values are anion excesses. Detection limit values were arbitrarily used for values less than detection limit.

$\mathrm{H}^{+}$- NET ION EXCHANGE STRONG ACID PRODUCTION - $B C_{\text {INPUT }}-\mathrm{BC}_{\text {OUTPUT }}$ Values of $\mathrm{BC}_{\text {INPUT }}-\mathrm{BC}_{\text {OUTPUT }} 0$ are assumed to represent soil and plant ion exchange production of strong acid, principally $H C l$. Values of $B C_{\mathbb{N} P U T}-\mathrm{BC}_{\mathrm{OUTPUT}} 0$ are assumed to represent net watershed production of $\mathrm{BC}^{-} \mathrm{SO}_{4}{ }^{2}, \mathrm{BC}-\mathrm{RCOO}$, and $\mathrm{BC}-\mathrm{HCO}_{3}{ }^{-}$, i.e:, in other words, production of basic sulfates, humates, and alkalinity exceeds watershed conversion of seasalts to strong mineral acidity. This definition of NET ION EXCHANGE STRONG ACID PRODUCTION assumes that watershed retention of marine SO ${ }_{4}$ converts input of $\mathrm{BC} \cdot \mathrm{SO}_{4 \text { marine }}$ to $\mathrm{BC}_{-} \mathrm{HCO}_{3}^{-}$. By this definition, because of watershed retention of marine $\mathrm{SO}_{4}$, there can be net watershed retention of base cations without net ion exchange production of strong acidity.

$B C_{I N P U T}-$ Total ionic concentration of base cations $\left(\mathrm{Na}^{+}+\mathrm{K}^{+}+\mathrm{Ca}^{2+}+\mathrm{Mg}^{2+}\right.$ in surface water is estimated to be equivalent to seaspray input assuming that all $\mathrm{Cl}^{-}$is due to seaspray and that all $\mathrm{SO}_{4}{ }^{2-}$ present in surface waters up to the $\mathrm{SO}_{4} / \mathrm{Cl}$ equivalent ratio of 0.1026 (that of seawater) is due atmospheric inputs of seaspray.

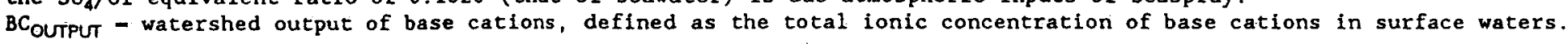


the very high rates of sulfate reduction (which are assumed in Table 23 to represent alkalinity production and, thereby, conversion of marine salts to bicarbonate solutions) it appears that net ion exchange production of strong acid would tend to more resemble the higher levels seen in southwestern Tasmania (Table 19). The higher rates of sulfate reduction for the coastal plain may reflect higher inputs of marine sulfate and/or natural differences due to terrain and hydrology (flatter and mostly seepage lakes) and climate (warmer) relative to western Tasmania.

Biological studies of Frazier Island waters, and other Australian coastal plain waters, show that their naturally acidic surface waters are much less hospitable to life than $\mathrm{pH} \gg 5.5$ waters of the coastal plain. These acidic waters have a relatively sparse fauna and flora typical of acid-stressed aquatic ecosystems (Bayley, 1964; Timns, 1982). Accordingly, acid-stressed aquatic ecosystems are not uniquely attributable to acidic deposition.

Acid-stress in aquatic ecosystems is related to both $\mathrm{H}^{+}$and aluminum, both of which act to disrupt ion and gas regulation of aquatic organisms (Braekke, 1976; Neville, 1985; Peterson and Martin-Robichaud, 1986; Gagen and Sharpe, 1987; Muniz et al., 1987). Concentration of $\mathrm{H}^{+}$has already been determined. Therefore, the chemistry of the other acid-stress agent, aluminum, was determined by Mark Peden of the Illinois State Water Survey for two $\mathrm{pH}<5.0$ Cooloola-Noosa waters: Bubbling Springs, a pH 4.89 clearwater, $\mathrm{DOC}=0.73$ $\mathrm{mg} / \mathrm{L}$, and Seary's Creek, a pH 4.84 colored water, DOC $=6.25 \mathrm{mg} / \mathrm{L}$ (Table 23). The fractionation and determination of aluminum species procedure and definitions currently used in Phase II of the NSWS (U.S. EPA, 1987) were used.

Essentially all of the dissolved aluminum (78 of the $80 \mathrm{ug} / \mathrm{L}$ ) in the 
naturally acidic clearwater is TOXIC ALUMINUM, inonganic monomeric aluminum which is believed to manifest acute toxic responses in fish (U.S. EPA, 1987). Even though $\mathrm{pH}$ values were essentially identical for both waters (pH 4.84 and 4.89), the acidic colored water had much more total aluminum in solution, 3.07 ug/:L. However, the acidic colored water has nearly as much TOXIC ALUMINUM, $55 \mathrm{ug} / \mathrm{L}$, as the acidic clearwater, $78 \mathrm{ug} / \mathrm{L}$. Both colored and clear, highly acidic waters have very similar concentrations of $\mathrm{H}^{+}$and TOXIC ALUMUNUM. Accordingly, both waters are expected to similarly toxic to aquatic ecosystems in respect to acid-stress.

In conclusion, these Australian water chemistry data support the data of Reeve and Fergus (1983) that podzol soils can naturally create highly acidic, clearwaters containing ionic aluminum. It appears that both aquatic stress agents, $\mathrm{H}^{+}$and ionic aluminum, are natural products of watersheds and are responsible for the common occurrence of acid-stressed aquatic ecosystems in areas of coastal Australia that do not receive acidic $\mathrm{H}_{2} \mathrm{SO}_{4}$ deposition.

Australian water chemistry and biology data do not support acidification theory. However, these data support the alternative hypotheses of acidification that acidification by acid rain is superimposed upon natural processes of acidification. These Australian data support the data of (Dahl, 1927; Rosenqvist, 1978; 1980; Jones et al., 1983; Retzsch et al., 1983; Krug et al., 1985; Lefohn and Klock, 1985; Rush et al., 1985) that highly acidic, toxic waters can be the natural result of watershed acidification processes.

Waters with pH55.5 appear to be the exception rather than the rule on the Australian coastal plain. Non-acidic surface waters on the Australian coastal plain appear to be related to watershed disturbance. To the best of my knowledge, the percentages of highly acidic clear and colored on the 
Australian coastal plain exceed any reported for "sensitive" watersheds in regions receiving acidic deposition.

Overall, data for the Amazon and the Australia coastal plain show that non-glaciated "sensitive" watersheds not receiving acidic deposition have proportions of highly acidic clear and colored surface waters equal to and exceeding that reported for "sensitive" watersheds receiving acidic deposition. Such naturally acidic surface waters have little living in them and are characterized by a sparse fauna and flora typical of acid-stressed aquatic ecosystems. Therefore, acid-stressed aquatic ecosystems are not uniquely attributable to acidic deposition. These data strongly suggest that reports of recent severe and widespread acidification of surface waters are more perceptual than real. 
CHAPTER 4

CONCLUSIONS

There is widespread belief that acidic deposition has caused lakes and streams in eastern North America to become acidic and lose their fish populations. In response to public and political concern, research on aquatic effects was initiated and supported by a number of public and private sponsors.

In the United States, the National Acid Precipitation Assessment Program (NAPAP) coordinates the Federal Govermment's efforts to improve the understanding of the causes and effects of acidic deposition, including an assessment of the role of acidic deposition in surface-water acidification. As Congress continues to deliberate on the issues of acidic deposition, and as NAPAP moves towards the delivery of its Final Assessment in 1990, it is important that decision-makers receive scientifically-sound information. Due consideration must be given to the many complex watershed processes that influence the chemistry of surface waters. Such information must be credible and arrived at through comprehensive and critical evaluation.

This report documents and assesses the evolution and status of the scientific hypotheses that have helped to guide the research of surface-water acidification. One of these hypotheses - most waters more acidic than predicted on the basis of carbonate chemistry are the result of "acid rain"has been elevated to the status of theory by its widespread acceptance.

Despite the long-held belief that the aquatic effects of acidic deposition is the best understood effects area, this area remains very controversial. 
While the public's perception that acidification of surface waters is associated with acidic deposition resulting from anthropogenic emissions of sulfur dioxide and nitrogen dioxide, it is possible that natural biological and chemical processes within watersheds may actually be responsible for much of the acidity.

Most reports of recent widespread acidification of surface waters are not based upon direct observation. These reports are the necessary conclusion of the fundamental premise of the accepted theory: most waters currently more acidic than predicted on the basis of carbonate chemistry have been recently acidified by $\mathrm{H}_{2} \mathrm{SO}_{4}$ deposition. It is believed that, in the absence of acidic deposition, water chemistry of "sensitive" watersheds is geologically controlled - natural water chemistry of sensitive watersheds is the product of carbonic acid $\left(\mathrm{H}_{2} \mathrm{CO}_{3}\right)$ weathering of mineral bases $\left(\mathrm{e} . \mathrm{g} ., \mathrm{Ca}^{2+}\right)$, which produces alkalinity $\left(\mathrm{HCO}_{3}{ }^{-}\right)$.

Alternative hypotheses of acidification predict that most currently acidic surface waters were acidic prior to acidic deposition. This is because the water chemistry of most currently acidic lakes and streams is not geologically controlled, nor was it geologically controlled by weathering of mineral bases prior to acidic deposition. currently acidic surface waters receive disproportionately large amounts of their water from highly acidic, organic-rich soils and peats and/or acidophilic ecosystems that mantle "sensitive" watersheds. Such near-surface runoff is not geologically controlled by weathering of mineral bases. Its chemistry is significantly influenced by organic acids and biologically-produced acids. The alternative hypotheses of acidification predict that acidic deposition/watershed interactions for such landscape elements includes the interaction of acid- 
with-acid rather than just the interaction of acid-with-mineral-bases. The alternative hypotheses of acidification also predict that the principal effect of acidic deposition on acidic surface waters has been the qualitative shift in the nature of acidity found in today's lakes and streams (e.g., from organic acids to sulfuric acid). It is expected that the interaction of "acid rain" with organic acids can be quite different from the interaction of "acid rain" with mineral bases as described by the accepted acidification theory.

Paleolimnology offers an independent means by which to test acidification theory and the alternative hypotheses of acidification. Paleolimnology can provide a direct answer to the question - in the pre-industrial era, were currently acidic $(\mathrm{pH}<5.5)$ lakes $\mathrm{HCO}_{3}^{-}$solutions of mineral bases having $\mathrm{pH}$ values greater than 5.5 , as predicted by the acidification theory, or were most currently acidic lakes naturally acidic (pH,5.5) prior to acidic deposition, as predicted by the alternative hypotheses of acidification?

Published paleolimnological investigations for 29 currently acidic $(\mathrm{pH}<5.5)$ surface waters in southern Norway and "sensitive" areas of the northeastern United States are reviewed - two areas for which numerous studies have claimed widespread and profound recent acidification of surface waters. Two of these 29 acidic lakes are also the focus of especially intensive, long-term acidification research which has been used to support acidification theory - Lake Langtjern in southern Norway, and Woods Lake in the Adirondack Mountains of New York.

Acidification theory and reports of recent widespread acidification for the Northeast and southern Norway are not well supported by paleolimnological studies. Paleolimnology indicates that approximately $90 \%$ of currently acidic 
$(\mathrm{pH}<5.5)$ surface waters examined in both regions were naturally acidic $(\mathrm{pH}<5.5)$ in the pre-industrial era. A National Academy of Science review concluded that the number of lakes with a pre-1800 diatom-inferred pH value less than 5.5 shows that acidic lakes were relatively common in the Adirondack Mountains and New England prior to the Industrial Revolution, as has also been shown by a review of paleolimnology for southern Norway.

Woods Lake and Lake Langtjern appear representative of the disagreement between paleolimnology and the accepted acidification theory. It has been concluded from application of acidification theory to current water chemistry that both lakes are highly acidic as the result of "acid rain". Nevertheless, paleolimnolgy shows that Lake Langtern ( $\mathrm{pH} 4.7$ ) has been acidic for at least the last 800 years. Over the last 800 years, Lake Langtjern was reported to be most acidic, $\mathrm{pH} 4.3$, around 1200 A.D. Similarly, Woods Lake ( $\left.\mathrm{pH}^{\sim} 5\right)$ had a pre-industrial $\mathrm{pH}$ of $\sim 5$.

The effects of land-use change and other types of watershed disturbance on acidification of surface waters is reported for many of the lakes examined, including Woods Lake, and other Adirondack, New England, and Norwegian lakes. It has been reported that it is difficult to find lakes that do not show the effects of watershed disturbance. Acidification of surface waters by acidic deposition appears to be superimposed upon natural processes of acidification and watershed disturbance.

Lakes that appear to have been bicarbonate waters which could have become acidified by acidic deposition appear to be the exception rather than the rule. Even for these lakes, change is not as great as expected: apparently due to both an acidic-deposition-induced shift from a more organic-rich water to a more organic-poor water, and; increased leaching of mineral bases (F- 
factor). Paleolimnology suggests that $\mathrm{F}$ is actually much larger than values empirically-derived from contemporary water chemistry data. Thus, less acidic deposition appears to be reaching "sensitive" surface waters than is commonly believed (i.e., more $\mathrm{SO}_{4}{ }^{2-}$ is entering the receiving water as basic sulfate (e.g., $\mathrm{CaSO}_{4}$ ) than is commonly believed).

In conclusion, paleolimnology indicates that the principal influence of acidic deposition on currently acidic $(\mathrm{pH}<5.5)$ Norwegian and Northeast lakes appears not to be a marked acidification but rather a qualitative shift in the nature of acidity from organic acid water to sulfuric acid water. Paleolimnology indicates that many currently acidic lakes were more organic rich in the pre-industrial era - although at least one currently acidic lake was an highly acidic clearwater highly acidified by strong acidity naturally produced by plant ion exchange.

Paleolimnological studies suggest that the principal detrimental aquatic effect of acidic deposition for currently acidic surface waters may be the loss of humic substances in naturally-acidic surface waters and a concomitant increase in the proportion of ionic aluminum.

In conclusion, paleolimnology studies for the Northeast and southerm Norway do not support the basic premise of acidification theory and two of its implicit theoretical assumptions:

1.) - current concentrations of organic acids represent preindustrial concentrations, and;

2.) - current watershed conditions represent pre-industrial conditions (i.e., no land-use change or other types of watershed disturbance and change have occurred).

"Sensitive" watersheds containing "acidified" surface waters tend to receive disproportionate amounts of near-surface runoff from highly acidic, organic-rich podzol soils and associated peats and acidophilic ecosystems. 
There are a number of locations in the world where such "sensitive", recently-glaciated and non-glaciated watersheds occur in the absence of manmade acidic deposition. Such watersheds can be used as controls to compare with "impacted" "sensitive" watersheds to independently test of the fundamental premises of accepted theory and the alternative hypotheses of acidification (and results of paleolimnology):

1.) - Acidification theory - most currently acidic surface waters are acidic because of acidic deposition.

2.) - Alternative hypotheses of acidification (and results of paleolimnologyl - acidification of surface waters by acidic deposition is superimposed upon natural processes of acidification. Most currently acidic surface waters were acidic in pre-industrial times. The principal effect of acidic deposition on currently acidic surface waters has been a qualitative shift in the nature of acidity.

The highly acidic, humic-rich landscapes typical of many "sensitive" watersheds in eastern North America and northern Europe are the result of the soil-forming process known as podzolization. The development of highly acidic, organic-rich podzol soils and associated peaty soils is most favored by moist, cool and temperate climates of the type encountered in recently-glaciated terrains such as southeast Canada, the Adirondack Mountains, New England, parts of the upper Midwest, southern Scandinavia, and maritime portions of northern mainland Europe. The intensity of the podzol soil-forming process diminishes as climate becomes progressively colder (to the north), drier (to the west in North America and east and south in Europe), and warmer to the south in both Europe and North America. Acidic deposition gradients also tend to decrease toward the cold Arctic as well as dry areas apparently because climate also influences human activity and industrial distribution (relatively little in the subarctic) and well as atmospheric processes (little precipitation and much alkaline dust in the 
drier areas). Thus, soil and atmospheric acidity gradients are correlated because both are fundamentally linked to climate in eastern North America and northern Europe. Unfortunately, such correlations have been reported as showing that "acid rain" is the cause of highly acidic soils and waters.

Highly acidic podzolized soils and associated peats, representative of recently-glaciated "sensitive" watersheds of eastern North America and southern Scandinavia exist in the southern hemisphere in the absence of manmade acidic deposition. This report examines such pristine, "sensitive" control watersheds and surface waters of recently-glaciated, moist and coolto-temperate climate regions of Australia and New Zealand.

Acidic deposition has also been credited with acidification of surface waters in "sensitive" non-glaciated regions with highly acidic soils. Podzolization also occurs on some non-glaciated terrains. Quartz sands and comparatively stable land surfaces enable podzolization to be pronounced in moist warm, and even moist tropical climates. An example of this are the podzolized soils and associated highly acidic peats of the Atlantic Coastal Plain of the eastern United States, which extend into the moist subtropical climate of Florida. Podzol soils and associated highly acidic peats are also widespread in the Amazon Basin and are developed from sandy deposits derived from granites and gneisses (base-poor, silica-rich rocks). Podzolized soils and peats analogous to those of the Atlantic Coastal Plain predominate on the sandy coastal deposits of Pacific Coastal Plain of eastern Australia, going from relatively moist and temperate Tasmania through the moist subtropical and tropical climates of Queensland. This report examines such pristine, "sensitive", non-glaciated control watersheds and surface waters of the Pacific Coastal Plain of eastern Australian and the Amazon. 
The first set of pristine, "sensitive" control watersheds for recentlyglaciated terrain is located in Tasmania. There are corresponding west-to-east climatic, soil, and vegetational gradients across Tasmania. Highly acidic podzol soils and peats, and associated acidophilic vegetation occur in the moist and recently-glaciated terrain of the west. The alternative hypotheses of acidification predict that acidic surface waters will co-occur only with the highly acidic, organic-rich soils and peats of the west. Thus, a surface water acidity gradient paralleling the soil acidity gradient is predicted.

Overall, $10 \%$ of 170 surveyed Tasmanian surface waters have $\mathrm{pH}$ values less than 5.0. In the glaciated, moist, and mountainous southwest, $37 \%$ of the sampled surface waters are $\mathrm{pH}<5.5$, and $28 \%$ are $\mathrm{pH}<5.0$. In the somewhat drier northwest, 9.5\% are $\mathrm{pH}<5.0$. There are no $\mathrm{pH}<5.0$ surface waters reported in the east. The flora and fauna of highly acidic Tasmanian waters are diagnostic of acid-stressed aquatic ecosystems.

All pH<5.0 Tasmanian waters surveyed are humic-rich. Highly acidic Tasmanian surface waters appear to be generally acidified by a mixture of naturally-occurring weak (humic) acids and, secondarily, by strong acids produced by soil/plant ion exchange. In most $\mathrm{pH}<5.0$ Tasmanian watersheds, ion exchange processes appear to play an important complementary role in acidification. Ion exchange appears to often result in the near-complete or complete removal of watershed-produced alkalinity through strong acid titration. Thus, ion exchange processes enable organic acids to have the apparently primary role in acidification of surface waters by removing most, or all, alkalinity so that organic acids can impart free $\mathrm{H}+$ to the water.

The second set of pristine, "sensitive" control watersheds for recently- 
glaciated terrain is located in New Zealand. Recently-glaciated terrain having highly acidic podzol soils and associated peats typical of many "sensitive" recently-glaciated watersheds of eastern North America and northern Europe is the west coast of the South Island of New Zealand. The precipitation chemistry $\mathrm{pH}$ of this area is remarkably clean (i.e., 5.6-5.7), similar to that at cape Grim in Tasmania.

Highly acidic surface waters occur in considerable numbers under forests of the west coast in association with the highly acidic podzols developed on the granites and glacial tills west of the Alpine Fault of the South Island of New zealand. pH values as acidic as 3.3 have been reponted for these Westland waters, ostensibly due to humic acids.

Analysis of Westland lakes and streams suggests that highly acidic $(\mathrm{pH}<5.0)$ surface waters may be the rule rather than the exception in these forested podzol soil watersheds. Iike Tasmania, acidification of these waters by organic acids appears to be enhanced by soil and plant ion exchange.

The first set of pristine "sensitive" control watersheds for non-glaciated terrain is located in the Amazon Basin. Highly acidic $(\mathrm{pH}<5.0)$ clear and colored surface waters exist in the Amazon Basin in association with highly acidic soils. Review of the scientific literature has found over $100 \mathrm{pH}<5.0$ stream survey observations of elearwater streams of remarkable transparency. Natives call the highly acidie waters of the Amazon "rivers of hunger"! because so little lives in them. The largest of these pH 4 rivers is the Rio Negro, which is about the size of the Mississippi River. It appears that highly acidic waters are the rule rather than the exception in the Rio Negro drainage basin, which is equivalent in size to a substantial portion of the 
United States.

Highly acidic surface waters also appear to be the rule rather than the exception for studied areas of the Pacific coastal Plain of eastern Australia - the second set of, pristine "sensitive" watersheds for nonglaciated terrain. The existence of the few $\mathrm{pH} \gg 5.5$ lakes and streams appears to be related to watershed disturbance which is, in turn, related to soil acidity. There is a general correlation between soil acidity and surfacewater acidity for the Australian Coastal Plain. Non-acidic surface waters tend to be in disturbed watersheds.

Surveys show that, overall, $84 \%$ of the examined larger, main, Coastal Plain lakes are $\mathrm{pH}<5.5$, and $79 \% \mathrm{pH} \leq 5.0$. Reported concentrations of DOC for highly acidic waters range from $0.5 \mathrm{mg} / \mathrm{L}$ to $39 \mathrm{mg} / \mathrm{L}$. Overall, for main lakes with both reported values of $\mathrm{DOC}$ and $\mathrm{pH}, 18 \%$ are $\mathrm{pH} \leq 5.0$ lakes having concentrations of DOC that are less than $2 \mathrm{mg} / \mathrm{L}$ and 25\% are $\mathrm{pH} \leq 5.0$ lakes having concentrations of DOC low enough to be considered clearwaters by the criteria set forth by Reuss et al. (1987). Like Tasmania and New Zealand, most highly acidic surface waters appear to be acidified by a mix of weak onganic acids and, secondarily, by strong acid (apparently $\mathrm{HCl}$ ) produced by soil and plant processes (apparently from seasalt). However, there is a sizeable minority of acidic clearwaters acidified by strong mineral acid (apparently HCl) with little or no anion deficit (or even anion excess) and low concentrations of DOC. Anion excesses are indicative of ionic metals, such as ionic aluminum, that are often not included in ion balance calculations.

Biological studies of Australian Coastal Plain waters, show that these naturally acidic surface waters are much less hospitable to life than $\mathrm{pH} \gg 5.5$ 
waters of the region. These acidic Australian waters have a relatively sparse fauna and flora typical of acid-stressed aquatic ecosystems. Accordingly, acid-stressed aquatic ecosystems are not uniquely attributable to acidic deposition.

Acid-stress in aquatic ecosystems is related to both $\mathrm{H}^{+}$and aluminum, both of which act to disrupt ion and gas regulation of aquatic organisms. Therefore, the chemistry of the other acid-stress agent, aluminum, was determined for some highly acidic Australian waters using the fractionation and aluminum speciation procedure, and definitions currently used in Phase II of the NSWS (U.S. EPA, 1987). Toxic aluminum was found in both colored and clear, pH<5.0 waters, with essentially all solution aluminum in clearwater being toxic aluminum.

In conclusion, these Australian water chemistry data support the data of Australian scientists (Reeve and Fergus, 1983) who have shown that podzol soils can naturally create highly acidic, clearwaters containing ionic aluminum. It appears that both aquatic stress agents, $\mathrm{H}^{+}$and ionic aluminum, are natural products of watersheds and are responsible for the common occurrence of acid-stresses aquatic ecosystems in areas of coastal Australia that do not receive acidic $\mathrm{H}_{2} \mathrm{SO}_{4}$ deposition.

overall, it appears that recently-glaciated and non-glaciated "sensitive" control watersheds not receiving acidic deposition can have proportions of highly acidic clear and colored surface waters equal to, and often exceeding that reported for any region of "sensitive" watersheds receiving acidic deposition. Such naturally acidic surface waters have little living in them and are characterized by a sparse fauna and flora typical of acid-stressed aquatic ecosystems. Therefore, acid-stressed aquatic ecosystems are not 
uniquely attributable to acidic deposition. These data strongly suggest that reports of recent severe and widespread acidification of surface waters are more perceptual than real.

The survey of "sensitive" control watersheds and their surface waters supports the following predictions of the alternative hypotheses of acidification:

1.) - The proportions of acidic surface waters in control "sensitive" watersheds and the existence of corresponding natural soil and water acidity gradients supports the hypothesis that acidic surface waters naturally co-occur with highly acidic, organic-rich soils and peats typical of many "sensitive" watersheds of eastern North America and northern Europe. Natural soil acidity gradients can result in natural surface water acidity gradients.

2.) - the qualitative and quantitative nature of acidity in control "sensitive" watersheds supports the hypothesis (and results of paleolimnology) that acidification of surface waters by acidic deposition is superimposed upon natural processes of acidification and that most currently acidic surface waters were acidic in pre-industrial times. The principal effect of acidic deposition on currently acidic surface waters is a qualitative shift in the nature of acidity resulting in the transformation of waters naturally acidified principally by weak organic acids to waters acidified principally by strong sulfuric acid with relatively little change in pH. Also, acidic-deposition-induced increased leaching of mineral base cations $\left(\mathrm{Ca}^{2+}+\mathrm{Mg}^{2+}+\mathrm{K}^{+}+\right.$ $\mathrm{Na}^{+}$) can mask the natural production of strong acid by soil and plant ion exchange that may co-occur with organic acidity in naturally-acidified waters.

A Norwegian scientist, Rosenqvist, was the first to offer alternative hypotheses of acidification: highly acidic soils can independently result in highly acidic surface waters; acidification by "acid rain" is superimposed upon natural acidification processes, and; recovery from watershed disturbances results in increasing soil acidity which can result in increasingly more acidic near-surface runoff. Most currently acidic lakes and streams receive disproportionately large amounts of their water as nearsurface runoff from highly acidic, organic-rich soils and peats and 
acidophilic ecosystems that are most influenced by disturbance (which results in loss of soil acidity) and recovery (which results in reacidification) •

Rosenqvist's changing land-use hypothesis is not only supported by the previously discussed paleolimnology and Australian watershed studies, but it is also supported by history. Both the creation of regional acidified precipitation and regional changes in land use are fundamentally linked by an underlying unifying factor - technological and societal change known as the demographic transition. The demographic transition is responsible for the quantitative increase in fossil fuel combustion and the qualitative changes in the types of fuels used and the nature of emissions from them. It is also responsible for fundamental changes in the way society perceives and uses the land. Thus, the effects of "acid rain" and land-use change are fundamentally linked and cannot be easily separated.

Changes in land use appear to be pervasive in areas where it is said that acidic deposition is responsible for surface-water acidification. Land-use and forest management studies show that the most devastating effects of abusive land use and concomitant greatest recovery have occurred in precisely those landscape elements where recovery naturally results in greatest soil acidification. Extensive review of the literature shows that essentially all land in the northeastern United States has been cut and/or burned within the last century. For example, the area of the Northeast with the least areal disturbance is New York State. Originally, New York was essentially completely forested. By the 1920's, 99.5\% of its forests were cut and/or burned. It is difficult to conceive that many Northeast watersheds were not influenced by human disturbance and land-use change and that currently 
"undisturbed" watersheds are not, in fact, recovering from earlier disturbance.

The altermative hypotheses of acidification are also supported by numerous laboratory and field studies reviewed in Chapter 3.

Laboratory and field experiments show that snowmelt chemistry is principally controlled by soil acidity. For example, the acidity of runoff from $\mathrm{pH} 4.3$ or 7.0 snowpack is virtually identical. Studies show that snowmelt $\mathrm{pH}$ consistently resembles soil $\mathrm{pH}$ and is but little influenced by snowpack acidity. Similar results are consistently obtained from laboratory and field experiments for simulated acid rainfall - runoff $\mathrm{pH}$ correlates to soil $\mathrm{pH}$ and is but little influenced by the $\mathrm{pH}$ of "rain". Thus, it follows that soil acidification induced by ecosystem recovery from disturbance can result in acidification of "sensitive" watersheds.

Laboratory and field studies indicate that the principal effect of acidic deposition is a qualitative shift in the nature of acidity resulting in the transformation of waters naturally acidified principally by weak organic acids to waters acidified principally by strong sulfuric acid with relatively little change in pH. Also, acidic-deposition-induced increased leaching of mineral base cations $\left(\mathrm{Ca}^{2+}+\mathrm{Mg}^{2+}+\mathrm{K}^{+}+\mathrm{Na}^{+}\right)$can mask the natural production of strong acid by soil and plant ion exchange that may co-occur with organic acidity in naturally-acidified waters. Laboratory and field studies indicate that the values of $\mathrm{F}$ for "sensitive" watersheds are much larger than the commonly-accepted values empirically-derived from water survey data.

Nevertheless, the conclusion necessitated by the fundamental premise of acidification theory (waters more acidic than predicted from carbonate chemistry are "acidified" by "acid rain") is favored over the above-described 
results of laboratory and field studies, paleolimnology, historical fact, and well-known principles and facts of related biological and earth sciences.

NAPAP is responsible for coordinating the Federal Govermment's efforts to improve the understanding of the causes and effects of acidic deposition. NAPAP is mandated to provide scientifically-sound information needed by the Congress and others in order to accurately assess the costs and benefits of emission controls and mitigation efforts. Establishing the role of acidic deposition in surface-water acidification is necessary in order to evaluate the benefits of emissions control.

NAPAP has stated that its assessment of the aquatic effects of acidic deposition should provide useful information for policy development. NAPAP's assessment:

- Must be credible, both to scientific reviewers and the users of the assessment information;

- Must be comprehensive, by examining the entire range of plausible causes, effects and control approaches;

- Must be critical, endorsing hypotheses that are supported by scientific research and rejecting unsubstantiated hypotheses.

The information contained within the pages that follow illustrate apparent inconsistencies that tend to point to weaknesses in acidification theory. some important factors and processes have not been adequately considered in NAPAP's assessment plans.

If NAPAP is to produce a credible assessment, it will be necessary for NAPAP to be perform a more comprehensive and critical evaluation of the existing evidence than has occurred previously. It is recommended that NAPAP consider all relevant factors and processes that are known to contribute to surface-water acidity and those that can buffer against acidic deposition. If NAPAP is unable to quantify these factors and processes, NAPAP may $4-15$ 
overestimate the possible damaging effects of acidic deposition on surface waters.

Based on a review of the literature and personal research experiences, it is recommended that some of the factors, processes, and facts that need to be considered more comprehensively and critically in order to establish a sound scientific basis for conducting an assessment include the following:

- The $\mathrm{H}^{+}$content of watersheds themselves, as well as $\mathrm{H}^{+}$from atmospheric deposition;

- The importance of elements, such as hydrogen, in naturallyoccurring, non-ionic compounds that can be converted to acids;

- The inclusion of erosional and depositional watershed processes in watershed input/output budgets;

- The acidification of waters by the production of strong mineral acids by plant and soil ion exchange;

- The climatically-driven gradients in natural soil acidity;

- The existence of highly acidic clearwaters and soils in the absence of acidic deposition;

- The existence of naturally-acidic clearwaters containing ionic aluminum;

- The finding that acidic lakes were relatively common in preindustrial times in the northeastern United States and southern Norway;

- The finding that some documented acidity-related fisheries problems date back to at least the early part of this century;

- The acidification/buffering nature of organic acids;

- The replacement of humic acids by strong mineral acids in water with little or no measurable change in $\mathrm{pH}$;

- The production of strong mineral acids from flocculated weak organic acids in soils and surface waters;

- The observation that principles of acid-with-acid interaction, as well as those of acid-with-base must be accounted for in the study of "sensitive" watersheds; 
- The production of strong acids from neutral salts;

- The enormous acid neutralizing capacity of even granitic watersheds, and;

- The natural re-acidification of watersheds as they recover from forest clearing and damage, or natural processes of disturbance.

Evidence continues to mount that natural biological and soil processes play an important role in defining surface water chemistry. There is no question that Man may be impacting surface waters by his emissions of sulfur dioxide and nitrogen dioxide. However, the way in which he chooses to use his land can also play an important role. If effective measures to control acidic surface waters are to be instituted, then a better understanding of the interaction of acidic deposition, natural acidification/buffering, and land use and other watershed disturbances is required.

It is hoped that the information contained in this report will provide some of the insight that is needed to better understand the uncertainties that are associated with the existing, accepted cause-and-effect acidic deposition theory. It is only through the serious consideration of some of the alternative hypotheses described in this report that levels of uncertainties can be better quantified. 
REFERENCES

1. Abrahamsen, G., A. Stuanes, and K. Bjor. 1978. Interaction between simulated rain and barren rock surface. Water, Air, Soil, pollut. 11:191-200.

2. Ad Hoc Committee on Acid Rain: Science and Policy. 1985. Is there scientific consensus on acid rain? Excerpts from six governmental reports. Mary Flagler Cary Arboretum, Millbrook, N.Y. 13 pages.

3. Adamson, A.W. 1973. A Textbook of Physical Chemistry. Academic Press, New York. 1079 pages.

4. Ahlgren, I.F. and C.E. Ahlgren. 1960. Ecological effects of forest fires. Bot. Rev. 26:483-533.

5. Almer. B., W. Dickson, C. Ekstrom, H. Hornstrom, and U. Miller. 1974. Effects of acidification on Swedish lakes. Ambio 3:30-36.

6. Andersson-Calles, U.M. and E. Eriksson. 1979. Mass balance of dissolved inorganic substances in three representative basins in Sweden. Nordic Hydrol. 10:99-114.

7. Andrus, R.E. 1986. Some aspects of Sphagnum ecology. Can. J. Bot. $64: 416-426$.

8. APHA (American Public Health Association). 1971. Standard Methods for the Examination of Water and Wastewater. 13th edition. American Public Health Association, Washington, D.C. 874 pages.

9. Armentano, T.V. and C.W. Ralston. 1980. The role of temperate zone forests in the global cartoon cycle. Can. J. For. Res. 10:53-60.

10. Ayers, G.P. and R.W. Gillett. 1984. Some observations on the acidity and composition of rainwater in Sydney, Australia, during the summer of 1980-81. J. Atmos. Chem. 2:25-46.

11. Ayers; G.P., J.P. Ivey, and H.S. Goodiman. 1986. Sulfate and methanesulfonate in the maritime aerosol at Cape Grim, Tasmania. J. Atmos. Chem. 4: 173-185.

12. Baker, J.P. and T.B. Harvey. 1984. Critique of acid lakes and fish poipulation status in the Adirondack Region of New York state. NAPAP Project E3-25. U.S. EPA, Corvallis, Oregon.

13. Bâyley, I.Ä.E. 1964. Chemical and biological studies on some acidic lakes of east Australian sandy coastal lowlands. Aust. J. Mar. Freshw. Res: 15:56-72.

14. Bayley, I.A.E. 1973. The sand fauna of Lake Pedder: A unique example of colonization by the Phreatoicidea (Crustacea: Isopoda). Aust. J. 
Mar. Freshw. Res. 24:303-306.

15. Bayley, I.A.E. 1982. Invertebrate fauna and ecology of temporary pools on granite outcrops on southern Western Australia. Aust. J. Mar. Freshw. Res. 33:599-606.

16. Bayley, I.A.E., E.P. Ebsworth, and H.F. Wan. 1975. Studies on the lakes of Frazier Island, Queensland. Aust. J. Mar. Freshw. Res. 26:113.

17. Beamish, R.J. 1976. Acidification of lakes in Canada by acid precipitation and the resulting effects on fishes. Water, Air, Soil, pollut. 6 :501-514.

18. Berden, M., S.I. Nilsson, K. Rosen, and G. Tyler. 1987. Soil acidification: Extent, causes and consequences. An Evaluation of literature information and current research. Natl. Swedish Environ. Prot. Bd. Rept. 3292. 164 pages.

19. Bergseth, H. 1977. Relationen zwischen aciditat und vegetationstyp norwegischer waldboden. Acta Agric. Scand. 27:269-279.

20. Bjorlykke, K.O. 1928. Soil types and soil profiles in Norway. Proc. Papers First Internat. Congr. Soil Sci. 4:223-269.

21. Braekke, F.H. (ed.). 1976. Impact of acid precipitation on forest and freshwater ecosystems in Norway. FR 6/76, SNSF-project, Oslo. 111 pages.

22. Bramryd, T. 1979. The effects of man on the biogeochemical cycle of carbon in terrestrial ecosystems. pp. 183-218. In: B. Bolin, E.T. Degens, S. Kempe, and P. Ketner (eds). SCOPE 13: The Global Carbon Cycle. John Wiley \& Sons. 491 pages.

23. Bridge, J.E. and F.P. Fairchild. 1981. Northeast Damage Report of the Long Range Transport and Deposition of Air Pollutants. Northeast Regional Task Force on Atmospheric Deposition. 72 pages.

24. Bridges, E.M. 1970. World Soils. Cambridge University Press, New York. 89 pages.

25. Buckney, R.T. and P.A. Tyler. 1973. Chemistry of Tasmanian inland waters. Int. Revue ges. Hydrobiol. 58:61-78.

26. Burns, D.A., J.N. Galloway, and G.R. Hendrey. 1981. Acidification of surface waters in two areas of the eastern United States. Water, Air, Soil, Pollut. 16:277-285.

27. Cain, S.A. 1931. Ecological studies of the vegetation of the Great Smoky Mountains of North Carolina and Tennessee. 1. Soil reaction and plant distribution. Bot Gaz. 91:22-41. 
28. Campbell, D.H. and J.T. Turk. 1988. Effects of sulfur dioxide emissions on stream chemistry in the western United States. Water Resourc. Res. 24:871-878.

29. Charles, D.F. and S.A. Norton. 1986. Paleolimnological evidence for trends in atmospheric deposition of acids and metals. Appendix E. Physical and chemical characteristics of some lakes in North America for which sediment-diatom data exist. pp. 335-431; 482-506. In: National Research Council, Acid Deposition Long-Term Trends. National Academy Press, Washington, D.C. 506 pages.

30. Charles, D.F. et al. 1987. Paleolimnological evidence for recent acidification of Big Moose Lake, Adirondack Mountains, N.Y. (U.S.A.). Biogeochem. 3:267-296.

31. Carter, V. 1986. An overview of the hydrologic concerns related to wetlands in the United States. Can. J. Bot. 64:364-374.

32. Clayton, J.S., W.A. Ehrlich, D.B. Cann, J.H. Day, and I.B. Marshall. 1977. Soils of Canada, Volume 1. Soil Report. Research Branch, Canada Department of Agriculture, Ottawa. 243 pages.

33. Clawson, M. 1979. Forests in the long sweep of American history. Science 204:1168-1174.

34. Clymo, R.S. 1963. Ion exchange in sphagmum and its relation to bog ecology. Ann. Bot. N.S. 27:309-324.

35. Clymo, R.S. 1984. Sphagnum-dominated peat bog: A naturally acid ecosystem. Phil. Trans. R. Soc. Lond. B. 305:487-499.

36. Collier, K.J. and M.J. Winterbourn. 1987. Faunal and chemical dynamics of some acid and alkaline New Zealand streams. Freshw. Biol. 18:227240 .

37. Congressional Committee on Energy and Commerce. 1982. Acid Precipitation (Part 1) Hearings Before the Subcommittee on Health and the Environment of the Committees on Energy and Cormerce, House of Representatives First Session on Effects and Solutions to combat Acid Precipitation, October 1,2 , and 6, 1981. U.S. Govermment Printing Office, Washington, D.C. 571 pages.

38. Cosby, B.J., G.M. Hornberger, J.N. Galloway, and R.F. Wright. 1985. Modeling the effects of acid deposition: Assessment of a lumped parameter model of soil water and streamwater chemistry. Water Resourc. Res. 21:51-63.

39. Cowling, E.B. 1980. An historical resume of progress in scientific and public understanding of acid precipitation and its biological consequences. FR 18/80, SNSF-project, Oslo. 29 pages.

40. Cowling, E.B. 1982. Acid precipitation in historical perspective. 
Environ. Sci. Technol. 16:110A-123A.

41. Cressey, P.J., G.R. Monk, H.J.K. Powell, and D.J. Tennent. 1983. Fulvic acid studies: Evidence for a polycarboxylate co-ordination mode at soil pH. J. Soil Sci. 34:783-799.

42. Dahl, K. 1927. The effects of acid water on trout fry. Salmon and Trout Magazine $\underline{46: 35-43 .}$

43. Davies, J.L. (ed). 1965. Atlas of Tasmania. Lands and Works Department of Tasmania, Hobart. 128 pages.

44. Davis, H. and C.J.B. Mott. 1981. Titrations of fulvic acid fractions : $\quad 1$. Interactions influencing the dissociation/reprotonation equilibria. J. Soil Sci. 32:379-391.

45. Davis, R.B., S.A. Norton, C.T. Hess, and D.F. Brakke. 1983. Paleolimnological reconstruction of the effects of atmospheric deposition of acids and heavy metals on the chemistry and biology of lakes in New England and Norway. Hydrobiologia 103:113-123.

46. Davis, R.B., D.S. Anderson, and F. Berge. 1985. Paleolimnological evidence that lake acidification is accompanied by loss of organic matter. Nature 316:436-438.

47. Davis, R.B., D.S. Anderson, D.F. Charles, and J.N. Galloway. 1988. Two-hundred-year pH history of Woods, Sagamore, and Panther lakes in the Adirondack Mountains, New York State. Aquatic Toxicology and Hazard Assessment: 10th Volume, ASTM STP 971:89-111.

48. Defebaugh, J.E. 1906. History of the Lumber Industry of America. Vol. 1. The American Lumberman, Chicago. 559 pages.

49. Defebaugh, J.E. 1907. History of the Lumber Industry of America. Vol. 2. The American Iumberman, Chicago. 665 pages.

50. De Vries, W. and A. Breeuwsma. 1987. The relation between soil acidificiation and element cycling. Water, Air, Soil, Pollut. 35:293310.

51. Diebold, C.H. 1941. Effect of fire and logging upon the depth of forest floor in the Adirondack region. Soil Sci. Soc. Amer. Proc. 6:409-413.

52. Dillon, P.J. and D.S. Jeffries, W. Snyder, R. Reid, N.D. Yan, D. Evans, J. Moss, and W.A. Scheider. 1978. Acidic precipitation in southcentral Ontario: Recent observations. J. Fish. Res. Board Can. 35:809815.

53. Donahue, R.L. 1940. Forest-site quantity studies in the Adirondacks 1. Tree growth as related to soil morphology. cornell U. Agric. Exp. Sta. Memoir 229. 44 pages. 
54. Douglas, M.S.V. and J.P. Smol. 1988. Siliceous protozoan and chrtysophycean microfossils from recent sediments of Sphagnum dominated Lake Colden, N.Y., U.S.A. Verh. Internat. Verein. Limnol. 23:855-859.

55. Dowd, J.F. 1984. Modeling Groundwater Flow into Lakes. Ph.D Thesis, Yale University, New haven, CT. 232 pages.

56. Drablos, D. and I. Sevaldrud. 1980. Lake acidification, fish damage and utilization of outfields. A comparative survey of six highland areas, southeastern Norway. pp. 354-355. In: D. Drablos and A. Tollan (eds). Ecological Impact of Acid Precipitation. SNSF-project, Oslo. 383 pages.

57. Drablos, D., I. Sevaldrud, and J.A. Timberlid. 1980. Historical landuse changes related to fish status development in different areas in southern Norway. pp. 367-369. In: D. Drablos and A. Tollan (eds). Ecological Impact of Acid Precipitation. SNSF-project, Oslo. 383 pages.

58. Driscoll, C.T. and G.E. Likens. 1982. Hydrogen ion budget of an aggrading forested ecosystem. Tellus 34:283-292.

59. Driscoll, C.T. and R.M. Newton. 1985. Chemical characteristics of Adirondack lakes. Environ. Sci. Technol. 19:1018-1024.

60. Driscoll, C.T., J.P. Baker, J.J. Bisogni, and C.L. Schofield. 1980. Effect of aluminum speciation on fish in dilute acidified waters. Nature 284:161-164.

61. Driscoll, C.T., N. Van Bremmen, and J. Mulder. 1985. Aluminum chemistry in a forested spodosol. Soil Sci. Soc. Am. J. 49:437-444.

62. Driscoll, C.T., R.D. Fuller, and D.M. Simone. 1988a. Longitudinal variations in trace metal concentrations in a northern forested ecosystem. J. Environ. Qual. 17:101-107.

63. Driscoll, C.T., N.M. Johnson, G.E. Likens, and M.C. Feller. 1988b. Effects of acidic deposition on the chemistry of headwater streams: A comparison between Hubbard Brook, New Hampshire, and Jamieson Creek, British Columbia. Water Resourc. Res. 24:195-200.

64. Duhaime, P.F., A.G. Everett, and W.C. Retzsch. 1983. Adirondack Land Use: A Commentary on Past and Present Impacts on Terrestrial and Aquatic Ecosystems. American Petroleum Institute, Washington, D.C.

65. Eaton, T.H. and R.F. Chandler. 1942. The fauna of forest-humus layers in New York. Cornell U. Agric. Exp. Sta. Memoir 247. 26 pages.

66. Fernow, B.E., C.D. Howe, and J.H. White. 1912. Forest Conditions of Nova Scotia. Commission of Conservation, Canada, Ottawa. 93 pages, plus index and maps. 
67. Fittkau, E.J. 1964. Remarks on limnology of central-Amazon rainforest streams. Verh. Internat. Verein. Limnol. 15:1092-1096.

68. Foth, H.D. 1984. Fundamentals of Soil Science, Seventh Edition. John Wiley \& Sons, New York. 435 pages.

69. Gagen, C.J. and W.E. Sharpe. 1987. Net sodium loss and mortality of three salmonid species exposed to a stream acidified by acidic deposition. Bull. Environ. Contam. Toxicol. 39:7-14.

70. Galloway, J.N., E.B. Cowling, E. Gorham, and W.W. McFee. 1978. A national program for assessing the problem of atmospheric deposition (acid rain). A report to the council on Environmental Quality. National Atmospheric Deposition Program NC-141. 97 pages.

71. Galloway, J.N., G.E. Likens, W.C. Keene, and M.M. Miller. 1982. The composition of precipitation in remote areas of the world. J. Geophys. Res. 87:8771-8786.

72. Gammon, N. Jr., J.R. Henderson, R.A. Carrigan, R.E. Caldwell, R.G. Leighty, and F.B. Smith. 1953. Physical, spectrographic and chemical analyses of some virgin Florida soils. U. Florida Agric. Exp. Sta. Bull 524. 130 pages.

73. Gherini, S.A., L. Mok, R.J.M. Hudson, G.F. Davis, C.W. Chen, and R.A. Goldstein. 1985. The IIWAS model: Formulation and application. Water, Air, Soil, Pollut. 26:425-459.

74. Gjessing, E.T. 1976. Physical and Chemical Characteristics of Aquatic Humus. Ann Arbor Press, Ann Arbor, Michigan. 120 pages.

75. Goldthwait, J.W. 1924. Physiography of Nova Scotia. Canada Geologic Survey Memoir 140. 179 pages.

76. Gore, A.J.P. (ed). 1983. Ecosystems of the World. 4B. Mires: Swamp, Bog, Fen and Moor. Elsevier, New York. 479 pages.

77. Gorham, E. and W.H. Pearsall. 1956. Acidity, specific conductivity and calcium content of some bog and fen waters in northern Britain. I. Ecol. 44:129-141.

78. Gorham, E. 1957. The chemical composition of lake waters in Halifax County, Nova Scotia. Limnol. Oceanogr. 2: 12-21.

79. Griffith, B.G., E.W. Hartwell, and T.E. Shaw. 1930. The evolution of soils as affected by the old field white pine-mixed hardwood succession in central New England. Harvard For. Bull. No. 15. 82 pages.

80. Haines, T.A. 1981. Acidic precipitation and its consequences for aquatic ecosystems. Trans. Amer. Fish. Soc. 110:669-707. 
81. Haines, T.A. and J. Akielaszak. 1983. A regional survey of the chemistry of headwater lakes and streams in New England: Vulnerability to acidification. FWS/OBS-80/40,15. 141 pages.

82. Haines, T.A. and J.P. Baker. 1986. Evidence of fish population responses to acidification in the eastern United States. Water, Air, Soil, Pollut. 31:605-629.

83. Hargrove, W.L. and G.W. Thomas. 1982. Conditional formation constants for aluminum-organic matter complexes. Can. J. Soil Sci. 62:571-575.

84. Harries, H. 1965. Soils and Vegetation of the Alpine Belt of the Presidential Range. Ph.D. Thesis, Rutgers University, New Brunswick, New Jersey. 542 pages.

85. Havas, M., T.C. Hutchinson, and G.E. Likens. 1984. Red herrings in acid rain research. Environ. Sci. Technol. 18:176A-186A.

86. Hayes, M.H.B. and R.S. Swift. 1978. The chemistry of soil colloids. pp. 179-320. In: D.J. Greenland and M.H.B. Hays (eds). The Chemistry of Soil Constituents. Wiley-Interscience, New York. 469 pages.

87. Heimburger, C.C. 1934. Forest-type studies in the Adirondack Region. Cornell U. Agric. Exp. Sta. Memoir 165. 122 pages.

88. Hendrey, G.R., J.N. Galloway, S.A. Norton, C.L. Schofield, D.A. Burns, and P.W. Schaffer. 1980. Sensitivity of the eastern United States to acid precipitation impacts on surface waters. pp. 216-217. In: D. Drablos and A. Tollan (eds). Ecological Impact of Acid Precipitation. SNSF-project, Oslo. 383 pages.

89. Henriksen, A. 1979. A simple approach for identifying and measuring acidification of fresh water. Nature 278:542-545.

90. Henriksen, A. 1980. Acidification of freshwaters -- A large scale titration. pp. 68-74. In: D. Drablos and A. Tollan (eds). Ecological Impact of Acid Precipitation. SNSF-project, Oslo. 383 pages.

91. Henriksen, A. 1982. Changes in base cation concentration due to freshwater acidification. Acid Rain Res. Rep. 1/1982. NIVA, Oslo. 50 pages.

92. Henriksen, A. 1984. Changes in base cation concentrations due to freshwater acidification. Verh. Internat. Verein. Limnol. 22:692-698.

93. Henriksen, A. and R.F. Wright. 1977. Effects of acid precipitation on a small acid lake in southern Norway. Nordic Hydrol. 8:1-10.

94. Henriksen, A. and D.F. Brakke. 1988. Sulfate deposition to surface waters. Environ. Sci. Technol. 22:8-14. 
95. Holloway, J.T. 1954. Forests and climates in the South Island of New Zealand. Trans. Roy. Soc. New Zealand 82:329-410.

96. Holzhey, C.S., R.B. Daniels, and E.E. Gamble. 1975. Thick Bh horizons in the North Carolina Coastal Plain: II. Physical and chemical properties and rates of organic additions from surface sources. Soil Sci. Soc. Amer. Proc. 39:1182-1187.

97. Houghton, R.A., J.E. Hobbie, J.M. Melillo, B. Moore, B.J. Peterson, G.R. Shaver, and G.M. Woodwell. 1983. Changes in the carbon content of terrestrial biota and soils between 1860 and 1980: A net release of $\mathrm{CO}_{2}$ to the atmosphere. Ecol. Monogr. 53:235-262.

98. Hsu, P.H. 1973. Appearance and stability of hydrolyzed $\mathrm{Fe}\left(\mathrm{ClO}_{4}\right)_{3}$ solutions. Clays Clay Min. 21:267-277.

99. Hutchinson, G.E. 1957. A Treatise on Limnology. Volume 1. Geography, Physics, and Chemistry. John Wiley \& Sons, New York. 1015 pages.

100. James, B.R. and S.J. Riha. 1986. pH buffering in forest soil organic horizons: Relevance to acid precipitation. J. Environ. Qual. 15:229234.

101. Jennings, J.N. 1957. Coastal dune lakes as exemplified from King Island, Tasmania. Geogr. J. 123:59-70.

102. Jenny, H. 1941. Factors of Soil Formation. MoGraw-Hill, New York. 281 pages.

103. Joffe, J.S. 1949. Pedology, Second Edition. Rutgers University Press, New Brunswick, New Jersey. 662 pages.

104. Johannessen, T.W. 1970. The Climate of Scandanavia. pp.23-79. IN C.C. Wallen (ed). Climates of Northern and Western Europe. Elsevier, New York. 253 pages.

105. Johansson, O. 1959. On sulfur problems in Swedish agriculture. Kungl. Lantbruks. Annal. 25:57-169.

106. Johnson, A.H. 1979. Acidification of headwater streams in the New Jersey Pine Barrens. J. Environ. Qual. $\underline{8}: 383-386$.

107. Johnson, N.M. 1979. Acid rain: Neutralization within the Hubbard Brook ecosystem and regional implications. Science 204:497-499.

108. Johnson, N.M. 1982. Acid rain neutralization by geologic materials. pp. 490-493. In: Amer. Chem. Soc. Div. Environ. Chem. 185th Natl. Meeting, Las Vegas, Nevada, March 28-April 2, 198222 (No. 1). 635 pages.

109. Johnson, N.M., C.T. Driscoll, J.S. Eaton, G.E. Likens, and W.H. MCDowell. 1981. "Acid Rain," dissolved aluminum and chemical

$$
\text { 5-8 }
$$


weathering at the Hubbard Brook Experimental Forest, New Hampshire. Geochim. Cosmochim. Acta. 45:1421-1437.

110. Jolly, V.H. and J.M.A. Brown (eds). 1975. New Zealand Lakes. Auckland University Press, Auckland. 388 pages.

111. Jones, H.C. et al. 1983. Investigations on the cause of fishkills in fish-rearing facilities in Raven Fork watershed. TVA/ORN/WR-83/9. 60 pages plus appendices.

112. Jones, M.L., D.R. Marmorek, B.S. Reuber, P.J. MaNamee, and L.P. Rattie. 1986. "Brown waters": relative importance of external and internal sources of acidification on catchment biota. Review of existing knowledge. IRTAP Workshop No. 5. Environment Canada and Dept. Fish. Oceans. 85 pages.

113. Junk, W.J. 1983. Ecology of swamps on the middle Amazon. pp. 269294. In: A.J.P. Gore (ed.). Ecosystems of the World 4B. Mires: Swamp, Bog, Fen and Moor. Elsevier, New York. 479 pages.

114. Kahl, J.S., J.L. Andersen, and S.A. Norton. 1985. Water resource baseline data and assessment of impacts from acidic precipitation, Acadia National Park, Maine. Technical Rept. 16. National Park Service, Boston. 118 pages.

115. Kanciruk, P., J.M. Eilers, R.A. Mocord, D.H. Landers, D.F. Brakke, and R.A. Linthurst. 1986. Characteristics of lakes in the eastern United States. Volume III: Data compendium of site characteristics and chemical variables. EPA/600/4-86/007c. 439 pages.

116. Keene, W.C., J.N. Galloway, and J.D. Holden, Jr. 1983. Measurements of weak organic acidity in precipitation from remote parts of the world. J. Geophys. Res. 88:5122-5130.

117. Kelley, W.P. 1948. A.C.S. Monograph \# 109: Cation Exchange in Soils. Reinholt, New York. 243 pages.

118. Kelso, J.R.M., C.K. Minns, J.E. Gray, and M.L. Jones. 1986. Acidification of surface waters in eastern canada and its relationship to aquatic biota. Canadian Spec. Publ. Fish. Aquat. Sci. 87.42 pages.

119. Kessel-Taylor, I. 1986. An examination of alternative causes of Atlantic salmon decline and surface water acidification in southwest Nova Scotia. Iands Directorate, Conservation and Protection, Environment Canada Working Paper No.46. 42 pages.

120. King, R.D. and P.A. Tyler. 1981. Limnology of Perched Lake, Southwest Tasmania. Aust. J. Mar. Freshw. Res. 32:501-515.

121. Klinge, H. 1965. Podzol soils in the Amazon Basin. J. Soil Sci. 16:95-103. 
122. Klinge, H. and W. Ohle. 1964. Chemical properties of rivers in the Amazonian area in relation to soil conditions. Verh. Internat. Verein. Limnol. 15:1067-1076.

123. Kramer, J. and A. Tessier. 1982. Acidification of aquatic systems: A critique of chemical approaches. Environ. Sci. Technol. 16:606A-615A.

124. Kramer, J.R., A.W. Andren, R.A. Smith, A.H. Johnson, R.B. Alexander, and G. Oehlert. 1986. Streams and lakes. pp. 231-299. In: National Research Council. Acid Deposition Long-Term Trends. National Academy Press, Washington, D.C. 506 pages.

125. Kramer, J.R. and S.S. Davies. 1988. Estimation of non-carbonato protolytes for selected lakes in the Eastern Lakes Survey. Environ. Sci. Technol. 22:182-185.

126. Krug, E.C. 1981. Geochemistry of Pedogenic Bog Iron and Concretion Formation. Ph.D. Thesis. Rutgers University, New Brunswick, New Jersey. 227 pages.

127. Krug, E.C. 1985. Acidification of soil and water. Nature 313:73.

128. Krug, E.C. 1987. Watershed affects on surface water chemistry. pp. 271-280. In: Proceedings of the Fourth Annual Pittsburgh Coal Conference. University of Pittsburgh, Pittsburgh. 985 page.

129. Krug, E.C. 1988. Some observations on NAPAP's findings on aquatic effects, its program, and the recent criticisms of bias it has received. pp. 160-175. IN: A.L. Lefohn and S.R. Krupa (eds). International Conference on Acidic Precipitation: A Technical Amplification of NAPAP's findings. Air Pollution Control Association, Pittsburgh. 239 pages.

130. Krug, E.C. and C.R. Frink. 1983a. Acid rain on acid soil: A new perspective. Science 221:520-525.

131. Krug, E.C. and C.R. Frink. 1983b. Effects of acid rain on soil and water. CT Agric. Exp. Sta. Bull. 811. 45 pages.

132. Krug, E.C. and P.J. Isaacson. 1984. Comparison of water and dilute acid treatment on organic and inorganic chemistry of leachate from organic-rich horizons of an acid forest soil. Soil Sci. 137:370-378.

133. Krug, E.C., P.J. Isaacson, and C.R. Frink. 1985. Appraisal of some current hypotheses describing acidification of watersheds. J. Air pollut. Control Assoc. 35:109-114.

134. Lag, J. 1968. Relationships between the chemical composition of the precipitation and the contents of exchangeable ions in the humus layer of natural soils. Acta Agric. Scand. 18:148-152.

135. Lag, J. 1979. Jordsmonnkart over Norge (Scale 1:2,000,000). Norges 
Landbruks., As.

136. Lawrence, G.B., R.D. Fuller, and C.T. Driscoll. 1986. Spatial relationships of aluminum chemistry in the streams of the Hubbard Brook Experimental Forest, New hampshire. Biogeochemistry 2:115-135.

137. Lefohn, A.S. and G.O. Klock. 1985. The possible importance of forest soil processes in defining surface water $\mathrm{pH}$ depressions. J. Air Pollut. Control Assoc. 35:632-637.

138. Likens, G.E. and F.H. Bormann. 1974. Acid rain: A serious regional environmental problem. Science 184:1176-1179.

139. Likens, G.E., R.F. Wright, J.N. Galloway, and T.J. Butler. 1979. Acid rain. Scientific American $241(4): 43-51$.

140. Likens, G.E., F.H. Bormann, R.S. Pierce, J.S. Eaton, and N.M. Johnson. 1977. Biogeochemistry of a Forested Ecosystem. Springer-Verlag, New York. 146 pages.

141. Linthurst et al. 1986. Regional chemical characteristics of lakes in North America: Part II - Eastern United States. Water, Air, Soil. Pollut. 31:577-591.

142. Little, I.P. and G.M. Roberts. 1983. Cations and silica in lake and creek waters from Fraser Island, Queensland in relation to atmospheric accession from the ocean. Proc. Roy. Soc. Qd. 94:41-49.

143. Iong, F.L., H.F. Perkins, J.R. Carreker, and J.M. Daniels. 1969. Morphological, chemical, and physical characteristics of eighteen representative soils of the Atlantic coast flatwoods. Southern Branch, Agric. Res. Serv., U.S. Dept. Agric. Res. Bull. 59. 74 pages.

144. Loucks, O.L., R.W. Miller, and T.V. Armentano. 1982. Regional Assessment of Aquatic Resources at Risk from Acidic Deposition. The Institute of Ecology, Indianapolis. 121 pages.

145. Lunt, H.A. 1932. Profile characteristics of New England forest soils. CT Agric. Exp. Sta. Bull. 342. pp.743-836.

146. Lunt, H.A. 1951. Liming and twenty years of litter raking and burning under red (and white) pine. Soil sci. Soc. Amer. Proc. $\underline{15}: 381-390$.

147. Lutz, H.J. and R.F. Chandler. 1946. Forest Soils. John Wiley \& Sons, New York. 514 pages.

148. MacDonald, A. 1925. Policy for forest land acquisition by New York State. J. Forestry 23:457-459.

149. Malanchuk, J.L. and R.S. Turner. 1987. Chapter 8. Effects on aquatic systems. In: NAPAP Interim Assessment, Volume IV: EFfects of Acidic 
Deposition. National Acid Precipitation Assessment Program, Washington, D.C.

150. Malmer, N. 1986. Vegetational gradients in relation to environmental conditions in northwestern European mires. Can. J. Bot. 64:375-383.

151. Marbut, C.F. 1935. Soils of the United States, Atlas of American Agriculture, Part III. U.S. Department of Agriculture, Washington, D.C.

152. Marshall, R. 1925. Recreational limitations to silviculture in the Adirondacks. J. Forestry 23:173-178.

153. Martell, A.E. and M. Calvin. 1952. Chemistry of the Metal Chelate Compounds. Prentice-Hall, New York.

154. McDowall, R.M. and G.A. Eldon. 1980. The ecology of Whitebait migrations (Galaxiidae: Galaxias spp.). Fish. Res. Bull. No. 20. New Zealand Ministry of Agriculture and Fisheries, Christchurch. 128 pages.

155. McLintock, A.H. 1960. A Descriptive Atlas of New Zealand. R.E. Owen, Govermment Printer, Wellington, New Zealand. 109 pages.

156. Means, J.I., R.F. Yuretich, D.A. Crerar, D.J.J. Kinsman, and M.P. Borcsik. 1981. Hydrogeochemistry of the New Jersey Pine Barrens. Bull N.J. Dept Environ. Prot. No. 76. 107 pages.

157. Mew, G. and M.L. Leamy. 1977. Some pedological trends from recent West Coast soil surveys and their relevance to forest use. New. Zealand. J. For. Sci. 7:151-161.

158. Mew, G. and R. Lee. 1981. Investigations of the properties and genesis of West Coast wet land soils, South Island, New Zealand. 1. Type localities, profile morphology, and soil chemistry. New Zealand J. Sci. $\underline{24}: 1-24$.

159. Mitchell, N.J. and M. Soukup. 1981. Analysis of Water Resource Management Alternatives with Enviromental Assessment: Cape Cod National Seashore. National Park Service, Boston, MA. 117 pages plus appendices.

160. Moore, T.R. 1976. Sesquioxide-cemented horizons in northern Quebec: Their distribution, properties and genesis. Can. J. Soil Sci. 56:333344.

161. Muniz, I.P., R. Andersen, and T.J. Sullivan. 1987. Physiological response of brown trout (Salmo trutta) spawners and postspawners to acidic aluminum-rich stream water. Water, Air, Soil pollut. 36:371-379.

162. NAPAP (National Acid Precipitation Assessment Program). 1984. Annual Report, 1983. National Acid Precipitation Assessment Program, Washington, D.C. 69 pages. 
163. NAPAP. 1986. Annual Report, 1985. National Acid Precipitation Assessment Program, Washington, D.C. 113 pages.

164. NAPAP. 1987a. Annual Report, 1986. National Acid Precipitation Assessment Program, Washington, D.C. 163 pages.

165. NAPAP. 1987b. Press Release on the Interim Assessment, for release: Thursday, September 17, 1987. National Acid Precipitation Assessment Program, Washington, D.C.

166. NAPAP. 1988. Plan and Schedule for NAPAP Assessment Reports 19891990: State of Science, State of Technology, Intergrated Assessment. National Acid precipitation Assessment Program, Washington, D.C.

167. National Research Council. 1981. Atmosphere-Biosphere Interactions: Toward a Better Understanding of the Ecological Consequences of Fossil Fuel Combustion. National Academy Press, Washington, D.C. 263 pages.

168. Neal, C., P. Whitehead, R. Neale, and J. Cosby. 1986. Modelling the effects of acidic deposition and conifer afforestation on stream acidity in the British Uplands. J. Hydrol. 86:15-26.

169. Nebergall, W.H., F.C. Schmidt, H.F. Holtzclaw. 1963. General Chemistry, 2nd edition. D.C. Heath and Co., Boston. 790 pages.

170. Neville, C.M. 1985. Physiological response of juvenile rainbow trout, Salmo gairdneri, to acid and aluminum - Prediction of field responses from laboratory data. Can. J. Fish. Aquat. Sci. 42:2004-2019.

171. Newbould, P.J. 1960. The ecology of Cranesmoor, a New Forest valley bog. J. ECOl. 48:361-383.

172. Nilsson, S.I., H.G. Miller, and J.D. Miller. 1982. Forest growth as a possible cause of soil and water acidification: An examination of the concepts. Oikos 39:40-49.

173. Oden, S. 1976. The acidity problem -- An outline of concepts. pp. 136. In: Proceedings of the First International Symposium on Acid Precipitation and the Forest Ecosystem. USDA For. Serv. Gen. Tech. Rep. NE-23. 1074 pages.

174. Oden, S. 1979. The sulphur budget of sweden during this century. Nordic Hydrol. 10:155-170.

175. Oliver, B.G., E.M. Thurman, and R.L. Malcolm. 1983. The contribution of humic substances to the acidity of colored waters. Geochim. Cosmochim. Acta 47:2031-2035.

176. Overrein, L.N., H.M. Seip, and A. Tollan. 1980. Acid precipitationEffects on Forest and Fish. Final report of the SNSF-project 1972-1980. FR 19/80, SNSF-project, Oslo. 175 pages. 
177. Pearce, A.J. and A.D. Griffiths. 1980. Effects of selective logging on physical water quality in small streams, Okarito Forest. J. Hydrol. (N.Z.) 19:60-67.

178. Pearsall, W.H. 1956. Two blanket-bogs in Sutherland. J. Ecol. 44: $493-516$.

179. Peterson, I. 1984. Soils and acid lakes: Finding common ground. Science News $12: 164$.

180. Peterson, L. 1976. Podzols and Podzolization. DSR Forlag, Copenhagen. 293 pages.

181. Peterson, R.H. and D.J. Martin-Robichaud. 1986. Growth and major inorganic cation budgets of Atlantic Salmon alevins at three ambient acidities. Trans. Amer. Fish. Soc. 115:220-226.

182. Pfeiffer, M.H. and P.J. Festa. 1980. Acidity Status of Lakes in the Adirondack Region of New York in Relation to Fish Resources. NY Dept. of Environ. Conserv., Albany, New York.

183. Plice, M.J. 1934. Acidity, antacid buffering, and nutrient content of forest litter in relation to humus and soil. Cornell U. Agric. Exp. Sta. Memoir 166. 32 pages.

184. Prince, A.B. and Raney, W.A. (eds). 1961. Some morphological, physical and chemical properties of selected northeastem United States soils. New Hampshire Agric. Exp. Sta. Misc. Publ. 1. 280 pages.

185. Reeve, R. and I.F. Fergus. 1983. Black and white waters and their possible relationship to the podzolization process. Aust. J. Soil Res. $\underline{21}: 67-72$.

186. Reeve, R., I.F. Fergus, and C.H. Thompson. 1985. Studies in landscape dymamics in the Cooloola-Noosa River Area, Queensland 4. Hydrology and water chemistry. CSIRO Div. of Soils Div. Rept. No. 77.42 pages.

187. Retzsch, W.C., A.G. Everett, P.F. Duhaime, and R. Northwanger. 1982. Alternative Explanations for Aquatic Ecosystems Effects Attributed to Acidic Deposition. Report prepared for the Utility Air Regulatory Group by Everett and Associates, Rockwell, MD.

188. Reuss, J.O. 1988. Comments on the national acidic deposition program's conclusions concerning the effect of acid deposition on aquatic systems. pp. 143-159. In: A.S. Lefohn and S. V. Krupa (eds). International Conference on Acidic Precipitation: A Technical Amplification of NAPAP's Findings. Air Pollution Control Association, Pittsburgh. 239 pages.

189. Reuss, J.O., N. Christophersen, and H.M. Seip. 1986. A critique of models for freshwater and soil acidification. Water, Air, Soil, Pollut. 30:909-930. 
190. Reuss, J.O., B.J. Cosby, and R.F. Wright. 1987. Chemical processes governing soil and water acidification. Nature 329:27-32.

191. Reuss, J.O. and D.W. Johnson. 1985. Ecological Studies 59: Acid Deposition and the Acidification of Soils and Waters. Springer-Verlag, New York. 119 pages.

192. Rhodehamel, E.C. 1973. Geology and water resources of the Wharton Tract and the Mullica River in southern New Jersey. N.J. Dept. Environ. Prot. Spec Rept. No. 36. 58 pages.

193. Ritchie, G.S.P. and A.M. Posner. 1982. The effect of $\mathrm{pH}$ and metal binding on the transport properties of humic acids. J. Soil Sci. 33: $233-247$.

194. Roberts, L. 1987. Federal report on acid rain draws criticism. Science 237:1404-1406.

195. Rosenqvist, I.Th. 1978. Alternative sources for acidification of river water in Norway. Sci. Total Environ. 10:39-49.

196. Rosenqvist, I.Th. 1980. Influence of forest vegetation and agriculture on the acidity of fresh water. pp. 56-79. In: J.R. Pfafflin and E.N. Ziegler (eds). Advances in Environmental Science and Engineering. Vol 3. Gordon and Breach Science Publishers. 224 pages.

197. Rueslatten, H.G. and P. Jorgensen. 1978. Interaction between bedrock and precipitation at temperatures close to $0^{\circ} \mathrm{C}$. Nordic Hydrol. 9:1-6.

198. Rush, R.M., R.B. Honea, E.C. Krug, R.W. Peplies, J.E. Dobson, and F.P. Baxter. 1985. An investigation of landscape and lake acidification relationships. ORNL/TM-9754.

199. Salbu, B., A.C. Pappas, and E. Steinnes. 1979. Elemental composition of Norwegian rivers. Nordic Hydrol. 10:115-140.

200. Sanden, P., A. Grimvall, and U. Lohm. 1987. Acidification trends in Sweden. Water, Air, Soil, Pollut. 36:259-270.

201. Schofield, C.L. 1976. Acid precipitation: Effects on Fish. Ambio $\underline{5}: 228-230$.

202. Schofield, C.L., J.N. Galloway, and G.R. Hendry. 1985. Surface water chemistry in the IIWAS basins. Water, Air, Soil, Pollut. 26:403-423.

203. Scruton, D.A., J.K. Elner, and G.D. Howell. 1987. Paleolimnological investigation of freshwater lake sediments in insular Newfoundland. Part 2: Downcore diatom stratigraphies and historical pH profiles for seven lakes. Canadian Tech. Rept. Fish. Aquat. Sci. No. 1521. 67 pages. 
204. Seip, H.M. 1980. Acidification of freshwater - Sources and mechanisms. pp. 358-366. In: D. Drablos and A. Tollan (eds). Ecological Impact of Acid Precipitation. SNSF-project, Oslo. 383 pages.

205. Seip, H.M., G. Abrahamsen, E.T. Gjessing, and A. Stuanes. 1979a. Studies of soil-, precipitation and run-off chemistry in six small natural plots ("mini-catchments"). IR46/79. SNSF-project, Oslo. 62 pages.

206. Seip, H.M., E.T. Gjessing, and H.Kamben. 1979b. Importance of the composition of the precipitation for the $\mathrm{pH}$ in runoff - Experiments with artificial precipitation on partly soil-covered "minicatchments." IR 47/79. SNSF-project, Oslo. 34 pages.

207. Seip, H.M., S. Andersen, and B. Halsvik. 1980. Snowmelt studied in a minicatchment with neutralized snow. IR65/80. SNSF-project, Oslo. 20 pages.

208. Seip, H.M. and A. Tollan. 1978. Acid precipitation and other possible sources for acidification of rivers and lakes. Sci. Total Environ. $\underline{10}: 253-270$.

209. Sioli, H. 1975. Chapter 8.2 Amazon Tributaries and Drainage Basins. pp. 199-213. In: A.D. Hasler (ed). Coupling of Land and Water Systems. Springer-Verlag, New York. 309 pages.

210. Skartveit, A. 1980. Observed relationships between ionic composition of precipitation and runoff. pp. 242-243. In: D. Drablos and A. Tollan (eds). Ecological Impact of Acid Precipitation. SNSF-project, oslo. 383 pages.

211. Skartveit, A. 1981. Relationship between precipitation chemistry, hydrology, and runoff acidity. Nordic Hydrol. 12:65-80.

212. Smith, M.W. 1938. A preliminary account of the fish populations in certain Nova Scotian lakes. Trans. Amer. Fish. Soc. 38:178-183.

213. Smith, R.A. and R.B. Alexander. 1983. Evidence for acidprecipitation-induced trends in stream chemistry at hydrologic benchmark stations. U.S. Geol. Surv. Circ. 910. 12 pages.

214. Sposito, G. 1984. The Surface Chemistry of Soils. Oxford University Press, New York. 304 pages.

215. Stevenson, F.J. 1977. Nature of divalent transition metal complexes of humic acids as revealed by a modified potentiometric titration method. Soil Sci. 123:10-17.

216. Stone, E.L. 1975. Effects of species on nutrient cycles and soil change. Phil. Trans. R. Soc. Lond. B. 271:149-162. 
217. Sullivan, T.J., J.M. Eilers, M.R. Church, D.J. Blick, K.N. Eshleman, D.H. Landers, and M.S. Dehaan. 1988. Atmospheric wet sulphate deposition and lakewater chemistry. Nature 331:607-609.

218. Tamm, O. 1950. Northern Coniferous Forest Soils. Translated from Swedish and modified by M.L. Anderson and 0 . Tamm from The Forest Soils of North Sweden, 1940 by O. Tamm. Scrivener Press, New York. 253 pages.

219. Thompson, C.H. 1981. Podzol chronosequences on coastal dunes of eastern Australia. Nature 291:59-61.

220. Thompson, C.H. 1983. Development and weathering of large parabolic dune systems along the subtropical coast of eastern Australia. $\underline{z}$. Geomorph. N.F. Suppl.-Bd. 45:205-225.

221. Thompson, C.H. and A.W. Moore. 1984. Studies in landscape dymamics in the Cooloola-Noosa River Area, Queensland. CSIRO Div. of Soils Div. Rept. No. 73 . 93 pages plus map.

222. Thompson, M.E. 1986. The cation denudation rate model - Its continued validity. Water, Air, Soil Pollut. 31:17-26.

223. Thompson, M.E., F.C. Elder, A.R. Davis, and S. Whitlow. 1980. Evidence of acidification of rivers of eastern Canada. pp. 244-245. In: D. Drablos and A. Tollan (eds). Ecological Impact of Acid Precipitation. SNSF-project, Oslo. 383 pages.

224. Thuman, E.M. 1986. Organic Geochemistry of Natural Waters. Martinus Nijhoff/Dr. W. Junk Publishers. Boston. 497 pages.

225. Thurman, E.M., R.L. Wershaw, R.L. Malcolm, and D.J. Pinckney. 1982. Molecular size of aquatic humic substances. Org. Geochem. 4:27-35.

226. Timms, B.V. 1982. Coastal dune waterbodies of north-eastern New South Wales. Aust. J. Mar. Freshw. Res. 33:203-222.

227. Troedsson, T. 1980. Long-term changes of forest soils. Ann. Agr. Fenniae 19:81-84.

228. Underwood, J.K., J.G. Ogden, III, J.J. Kerekes, and H.H. Vaughan. 1987. Acidification of Nova Scotia lakes. Water, Air, Soil, Pollut. 32:77-88.

229. U.S. EPA. 1980a. Acid rain. EPA-600/9-79-036. 36 pages.

230. U.S. EPA. 1980b. Acid rain. Vol. 1. Office of Research and Development, U.S. EPA. U.S. EPA, Washington, D.C.

231. U.S. EPA. 1984. The acidic deposition phenomenon and its effects: Critical assessment review papers. Volume II. Effects sciences. EPA$600 / 8-83-016 \mathrm{BF}$. 
232. U.S. EPA. 1987. Handbook of methods for acidic deposition studies: Laboratory analysis for surface water chemistry. EPA 600/4-87/026.

233. U.S. Soil Conservation Service. 1967. Soil survey laboratory data and descriptions for some soils of Georgia, North Carolina, South Carolina. Soil Conserv. Serv., U.S. Dept. Agric. Soil Surv. Invest. Rept. No. 16. 109 pages plus maps.

234. Van Breemen, N., C.T. Driscoll, and J. Mulder. 1984. Acidic deposition and internal proton sources in acidification of soils and waters. Nature 307:599-604.

235. Van Breemen, N., C.T. Driscoll, and J. Mulder. 1985. Reply to "Acidification of soil and water." Nature 313:73.

236. Van Wambeke, A. 1976. Formation, distribution and consequences of acid soils in agricultural development. pp.15-24. IN: M.J. Wright and S.A. Ferrari (eds). Plant Adaptation to Mineral stress in Problem Soils, Proceedings of a Workshop held at the National Agricultural Library, Beltsville, Maryland, November 22-23, 1976. 420 pages.

237. Veneman, P.L.M., P.V. Jacke, and S.M. Bodine. 1984. Soil formation as affected by pit and mound microrelief in Massachusetts, USA. Geoderma 33:89-99.

238. Verhoeven, W., R. Hermann, R. Eiden, and O. Klemm. 1987. A comparison of the chemical composition of fog and rainwater collected in the Fichtelbirge, Federal Republic of Germany, and from the South Island of New Zealand. Theor. Appl. Climatol. 38:210-221.

239. Viro, P.J. 1974. Effects of forest fire on soil. pp.7-45. In: T.T. Kozlowski and C.E. Ahlgren (eds). Fire and Ecosystems. Academic Press, New York. 542 pages.

240. Vitt, D.H. and S. Bayley. 1984. The vegetation and water chemistry of four oligotrophic basin mires in northwestern ontario. Can. J. Bot. 62:1485-1500.

241. Watt, W.D., D. Scott, and S. Ray. 1979. Acidification and other chemical changes in Halifax County lakes after 21 years. Limnol. oceanogr. 24:1154-1161.

242. Watt, W., C. Scott, and W. White. 1983. Evidence of acidification of some Nova Scotian rivers and its impact on Atlantic salmon, Salmo Salar. Can. J. Fish. Aquat. Sci. 40:462-473.

243. Wershaw, R.L. and D.J. Pinckney. 1971. Association and dissociation of a humic acid fraction as a function of $\mathrm{pH}$. U.S. Geol. Survey Prof. Paper 750-D, pp. 216-218.

244. Wherry, E.T. 1928. Review: Ten years of work on soil reaction as an ecological factor. Ecology 9:532. 
245. White, J.R. and C.T. Driscoll. 1985. Lead cycling in an acidic Adirondack lake. Environ. Sci. Technol. 19:1182-1187.

246. Winkler, M.G. 1985. Diatom Evidence of Environmental Changes in Wetlands. Part 1. Prehistoric and Historic Trends in Acidity of the Kettle Ponds in the Cape Cod National Seashore. National Park Service, Boston, MA. 46 pages plus figures and tables.

247. Winkler, M.G. 1988. Paleolimnology of a Cape cod kettle pond: Diatoms and reconstructed pH. Ecol. Monogr. 58:197-214.

248. Woodward, K.W. 1906. Forestry in Nova Scotia. J. Forestry 4:10-13.

249. Wright, R.F. 1977. Historical changes in the pH of 128 lakes in southern Norway and 130 lakes in southern Sweden over the period 19231976. IN 34/77. SNSF-project, Oslo. 71 pages.

250. Wright, R.F. 1983. Input-output budgets at Langtjern, a small acidified lake in southern Norway. Hydrobiologia 101:1-12.

251. Wright, R.F. 1987. RAIN Project. Annual Report for 1986. Norw. Inst. Water Research (NIVA) Report 13/1987. 90 pages.

252. Wright, R.F. 1988. Acidification of lakes in the eastern United States and southern Norway: A comparison. Environ. Sci. Technol. $\underline{22}: 178-182$.

253. Wright, R.F. and E.T. Gjessing. 1976. Changes in the chemical composition of lakes. Ambio 5: 219-223.

254. Wright, R.F. and E. Snekvik. 1977. Chemistry and fish populations in 700 lakes in southermmost Norway. TN 37/77. SNSF-project, Oslo. 84 pages.

255. Wright et al. 1977. Regional surveys of small Norwegian lakes. TR 33/77. SNSF-project, Oslo.

256. Wright, R.F. and A. Henriksen. 1978. Chemistry of small Norwegian lakes, with special references to acid precipitation. Limnol. Oceanogr. 23:487-498.

257. Wright, R.F., E. Lotse, and A.Semb. 1988. Reversibility of acidification shown by whole-catchment experiments. Nature 334:670675.

258. Young, V.A. 1934. Plant distribution as influenced by soil heterogeneity in Cranberry Lake region of the Adirondack Mountains. Ecology 15:154-196. 